\title{
Bancários com LER (Lesões por Esforços Repetitivos) \\ e sua reabilitação profissional: possibilidades e limites \\ no retorno ao trabalho
}

\section{Marcia Elena Rodrigues Gravina}

Tese apresentada ao Programa de PósGraduação em Saúde Pública para obtenção do título de Doutor em Saúde Pública

Área de Concentração: Saúde Ambiental Saúde dos Trabalhadores

Orientadora: Profa. Dra. Lys Esther Rocha

São Paulo 
Autorizo, exclusivamente para fins acadêmicos e cientificos, a reprodução total ou parcial desta tese, por processos fotocopiadores.

Assinatura:

Data:

$$
452181.2004 \text { doc }
$$




\section{DEDICATÓRIA}

Este espaço é dedicado ao Prof. Dr. DIOGO PUPO NOGUEIRA, orientador inicial deste trabalho.

O Professor sempre foi por mim considerado como um exemplo

na área da saúde do trabalhador,

tal o seu profissionalismo e conhecimento.

Um ser humano de valor inestimável, inspirava segurança, sempre disponivel a ouvir com interesse, contribuindo para o meu crescimento pessoal.

Ficam aqui registrados os meus sinceros agradecimentos pela orientação e incentivo aos meus estudos. 


\section{AGRADECIMENTOS}

É muito dificil citar os nomes de todas as pessoas que, de alguma forma contribuíram para a realização deste estudo.

Mesmo correndo o risco da omissão, não poderia deixar de agradecer a todas as pessoas que trilharam este caminho comigo, e em especial àqueles que tornaram possível a concretização da tese:

À Profa. Dra. Lys Esther Rocha, que me aceitou como sua aluna, por sua dedicação em ensinar, por sua confiança no meu trabalho e seu apoio sempre que eu precisei.

Aos componentes da banca examinadora que, com seus pareceres, enriqueceram o estudo e me permitiram reflexões mais profundas sobre o tema.

Ao Sr. Adair que colaborou comigo na correção da língua portuguesa.

Aos bancários, em especial àqueles que, confiando na minha pessoa, expuseram um momento dificil de suas vidas, de maneira aberta, demonstrando seus sentimentos sem receios. 


\section{RESUMO}

Gravina, MER Bancários com LER (Lesões por Esforços Repetitivos) e sua reabilitação profissional: possibilidades e limites no retorno ao trabalho. São Paulo; 2004 I Tese de Doutorado - Faculdade de Saúde Pública da USP]

Objetivo: Dentro do contexto do trabalho, atualmente, alguns trabalhadores no exercício profissional adoecem e se afastam. Após seu restabelecimento precisam retomar suas atividades laborativas, porém com restrições. Nesse sentido realizou-se estudo com o objetivo de avaliar o processo de reabilitação profissional entre bancários com lesões por esforços repetitivos, verificando dificultadores e facilitadores. Procedimentos metodológicos: $O$ estudo baseou-se no atendimento do programa de reabilitação de um banco, além do desenvolvimento de um grupo com trabalhadores com LER, previsto no programa. Para aprofundamento dos dados foram realizadas entrevistas com 16 bancários que passaram pelo processo de reabilitação. Foi utilizado um roteiro semi - estruturado e o Discurso do Sujeito Coletivo para a análise, fundamentado na Teoria das Representações Sociais. Resultados: Quanto ao grupo, as pessoas que participaram apresentaram dificuldades com relação a: estabelecimento de limites, preconceito, resistência, pouco investimento do banco em recursos humanos, pressão para o atingimento de metas, insegurança e medo com relação ao futuro. Como facilitadores mencionaram a participação no grupo, o acompanhamento multidisciplinar e a discussão das atividades laborativas antes $\mathrm{da}$ recolocação. No que diz respeito às entrevistas os resultados foram divididos em temas $\mathrm{e}$ subtemas da seguinte forma: LER, a vivência que não se esquece; questões e situações que desfavoreceram a reabilitação profissional, cujos depoimentos estiveram relacionados às dificuldades no relacionamento interpessoal e à organização do trabalho; e aspectos contributivos: o fato de o trabalho ser visto por muitos como um fator de inclusão social e o suporte social. Conclusões: A reabilitação se mostrou possível de ser efetuada, apesar de ser uma atividade complexa para os trabalhadores e para a sociedade. Os fatores primordiais apontados como insucesso no processo de reabilitação foram a organização do trabalho e as relações interpessoais. Portanto qualquer ação de reabilitação no contexto da saúde dos trabalhadores deve contemplar estes dois aspectos.

DESCRITORES: Reabilitação Profissional; Lesões por Esforços Repetitivos; Trabalho Bancário; Fatores Psicossociais. 


\section{SUMMARY}

GRAVINA, MER Bank workers with RSI (Repetitive Strain Injuries) and their occupational rehabilitation: facilities and difficulties at the return to work. São Paulo; 2004 [PHD - Faculdade de Saúde Pública - USP]

Aim: Nowadays inside of the work context, some workers get sick and stay away from work. After their re-establishiment they need to return to work, however with physical or mental restrictions. In this way, a study has been concluded analysing the process of occupational rehabilitation among bank workers with RSI, to check facilities and difficulties at the process. Metodological Proceedings: The study was based on a bank rehabilitation program, and the development of a workshop with bank workers with RSI, presupposed on the bank program. Due to get deeper into the data, some interviews were made with 16 bank workers that had been passed through the rehabilitation's process. The interview followed two different procedures: a script and the collective subject speech, based on Social Representations Theory. Results: Relative to workshop the workers presented difficulties in: establishiment of limits, prejudice, resistence, low investiment of the bank in human resources, pressure to achieve the goals, uncertainly and worries about the future. The facilities were: to have been participated in the workshop and assisted by a multidisciplinary team, and the discussion about professional activities before their replacement. Analysing the interviews, the results were divided in issues: RSI, the unforgetable experience; unfavorable situations to the occupational rehabilitation with depoiments related to relationship and the work's organization, and the contributives aspects: the fact of work being considerated by many people as a factor of social inclusion and support. Conclusions: Despite of being a complex activity for the workers and the society, the occupational rehabilitation was possible. The main appointed factors leading to failure in the rehabilitation process were the organization of the work and the relationships. Therefore, all kinds of action in occupational rehabilitation should involve both aspects.

KEYWORDS: Occupational Rehabilitation; Repetitive Strain Injuries; Bank worker; Psychosocial issues. 


\section{ÍNDICE}

1 INTRODUÇÃO

1.1 Algumas considerações sobre o mundo do trabalho contemporâneo 09

1.2 A automação bancária no Brasil 15

1.3 As LER - Lesões por Esforços Repetitivos em bancários 21

1.4 A reabilitação profissional 27

2 A SITUAÇÃO NO BANCO ESTUDADO

2.1 A automação bancária 37

2.2 As Ler - Lesões por Esforços Repetitivos 39

3 OBJETIVOS

3.1 Objetivo Geral 43

3.2 Objetivos Específicos $\quad 43$

4 PROCEDIMENTOS METODOLÓGICOS

4.1 Metodologia utilizada 44

4.2 Procedimentos adotados $\quad 47$

4.3 Descrição dos sujeitos que participaram das entrevistas 53

5 RESULTADOS

5.1 Quanto ao Programa de Reabilitação Profissional 55

5.2 Quanto ao trabalho com o Grupo de Atenção 60

5.3 Quanto às entrevistas realizadas utilizando-se a metodologia do Discurso do Sujeito Coletivo:

5.3.1 LER: a vivência que não se esquece

5.3.2 Questões e situações que desfavoreceram $\begin{array}{ll}\text { a reabilitação profissional } & 77\end{array}$

5.3.3 Aspectos contributivos ao retorno ao trabalho 91 
6 DISCUSSÃO

6.1 Questões e situações que desfavoreceram a reabilitação $\begin{array}{ll}\text { Profissional } & 100\end{array}$

6.2 Aspectos contributivos para o retorno ao trabalho 119

$\begin{array}{lll}6.3 & \text { A vivência da LER } & 125\end{array}$

7 CONCLUSÕES 137

8 REFERÊNCIAS $\quad 140$ 


\section{ANEXOS}

I Quadro Resumo do Total de Empregados Atendidos no PRT - Programa de Readaptação ao Trabalho - do Banco estudado no âmbito do SESMT - Serviço de Engenharia de Segurança e Medicina do Trabalho em São Paulo

II Quadros com dados demográficos da população total de empregados atendidos no PRT - Programa de Readaptação ao Trabalho - do Banco estudado no âmbito do SESMT em São Paulo e dos sujeitos que participaram das entrevistas

III Instrumento de Análise do Discurso I - IAD I

IV Termo de Consentimento Livre e Esclarecido utilizado na presente pesquisa 


\section{INTRODUÇÃO}

\subsection{Algumas considerações sobre o mundo do trabalho contemporâneo}

Tendo em vista tratar-se de um estudo voltado para as relações de trabalho, optou-se por iniciar a análise com algumas considerações teóricas a respeito do mundo do trabalho contemporâneo. É claro, aqui não é lugar de se fazer uma avaliação detalhada de toda a transformação que ocorreu e ainda está em curso na sociedade do trabalho. Mas é importante destacar alguns pontos relevantes para a análise do contexto em que está inserido o trabalhador bancário, objeto desta pesquisa.

$\mathrm{O}$ trabalho enquanto atividade humana vem sofrendo variações em seu conceito $\mathrm{e}$ sentido ao longo da história, dependendo da época e da cultura reinantes. Segundo Marx (1867), importante teórico das relações de trabalho, o homem imprime inteligência à atividade e, mais ainda, sentido e sentimento à ação. $O$ trabalho vai além do instinto, modifica a natureza em um movimento de dar e receber, acabando por criar o mundo tal qual se apresenta atualmente.

Alguns autores, que serão citados abaixo, apresentam uma importante divisão histórica, social, econômica e cultural, cujos períodos foram denominados: modernidade e pós - modernidade.

Habermas (1983) chamou de projeto da modernidade o movimento que teve seu início no século XVIII e foi um esforço de intelectuais iluministas para desenvolver áreas como a ciência, a moralidade, a lei e a arte, ou seja, usar o conhecimento de muitas pessoas em prol da emancipação humana. Além disso o projeto previa: formas racionais de organização social, distância da religião e a liberação do uso do poder. Pode-se considerar este como o inicio do sistema capitalista de produção. Esse tempo começou sob a bandeira de liberdade e luta contra os antigos regimes, tradições e leis. Mas essa liberdade tinha um sentido particular que era de permitir a ascensão da burguesia enquanto classe dominante. 
Críticos do projeto e do pensamento iluminista que o acompanha, Horkheimer e Adorno (1972) acreditavam que o projeto iria voltar-se contra si mesmo, fazendo com que essa busca da emancipação humana se tornasse um sistema de opressão universal.

Bernstein (1985) apresenta a crítica de Weber sobre o movimento iluminista que tinha como lema o desenvolvimento da ciência, da racionalidade e da liberdade humana, mas na verdade seu verdadeiro legado foi a racionalidade que afeta todos os planos da vida social e cultural com abrangência nas estruturas, no direito, na administração burocrática e nas artes.

Marx (1867) analisando o sistema capitalista faz referência às coisas que os homens devem consumir no decorrer de sua própria existência, tais como comida, roupa, etc, e que ele chamou de mercadoria. Ele adverte que a mercadoria contém ao mesmo tempo dois valores diferentes: um valor de uso, ou seja quando a mercadoria atende a uma necessidade humana; e um valor de troca, quando uma determinada mercadoria pode ser usada para ser trocada por outras mercadorias também necessárias.

Continuando nesta análise, à medida que cresce esse mercado de trocas, a mercadoria se transforma em dinheiro, que tem uma outra representação na sociedade do trabalho. A mercadoria então assume uma outra característica de valor, que é dada pelo dinheiro. A valoração do produto fica cada vez maior, em detrimento do produtor, ou seja, sem o trabalho de nada adiantaria o dinheiro, mas na sociedade do trabalho, é somente através do dinheiro que o trabalho pode ser representado e valorado.

Por volta de 1848 começa a desmoronar o pensamento da existência de uma única categoria de representação, como queria o iluminismo. Harvey (1993) apresenta como fortes razões para aquelas mudanças a publicação do Manifesto do Partido Comunista, por Marx e Engels e as revoluções que o precederam. É a partir desse movimento histórico, social e cultural que tem início o pós - modernismo. 
Harvey (1993) avalia que, no pós - modernismo, a preocupação fundamental continua no dinheiro e não no trabalho em si: o dinheiro concede o privilégio de se exercer o poder sobre outras pessoas. O autor indica o ano de 1973 como um marco histórico importante, porque foi a primeira vez que o sistema capitalista do pós - guerra encarou, em todo o mundo, uma grande recessão na economia, atingindo, é claro, todos os setores da sociedade do trabalho. A grande inflação deflagrada nesse período provocou uma crise nos mercados imobiliários e nas instituições financeiras. Pôde ser acrescentada a decisão da OPEP em aumentar os preços do petróleo, bem como a resolução árabe de não exportar petróleo para o ocidente durante a guerra entre árabes e israelenses, naquela época.

Para explicar sobre esse periodo, Harvey (1993) recorreu à linguagem de uma escola de pensamento chamada "escola de regulamentação", que teve como pioneiro Aglietta (1979) e alguns propositores, entre eles Lipietz (1986) e Boyer (1986), resumindo: “....um regime de acumulação descreve a estabilização, por um longo período, da alocação do produto líquido entre consumo e acumulação; ele implica alguma correspondência entre a transformação tanto das condições de produção como das condições de reprodução de assalariados.” (pg. 117)

Lipietz (1986) chamou de modo de regulamentação as regras e processos sociais que foram interiorizados com vistas a garantir a consistência apropriada entre as ações individuais e o esquema de reprodução social.

Para dar continuidade à produção tal como se apresentava, Harvey (1993) colocou que o sistema capitalista teve que ultrapassar duas dificuldades: as qualidades anárquicas dos mercados de fixação de preços e o controle sobre o emprego da força de trabalho.

Para a primeira dificuldade existe o Estado como controlador das consequências e, além disso outras instituições (religiosas, políticas, sindicais, patronais e culturais) também interferem na dinâmica, procurando favorecer o capitalismo. Há que se considerar também a interferência das propensões sociais e psicológicas. Harvey (1993) assentou que "a virtude do pensamento da "escola de regulamentação" está no fato de insistir que levemos 
em conta o conjunto total de relações e arranjos que contribuem para a estabilização do crescimento do produto e da distribuição agregada de renda e de consumo num período histórico e num lugar particulares." (pg. 118)

Para a segunda dificuldade a sociedade capitalista contou com a conversão da capacidade do trabalho ativo em um processo produtivo cujos frutos pudessem ser apropriados pelos capitalistas, o que envolvia: repressão, familiarização, cooptação e cooperação; socialização através do controle social das capacidades físicas e mentais; educação, treinamento, mobilização de sentimentos. Essas medidas estavam claramente apresentadas pelos meios de comunicação de massa, instituições religiosas e educacionais e Estado.

Todos estes acontecimentos colocaram em curso um conjunto de processos que afetaram profundamente o sistema fordista, dominante como forma de produção no capitalismo, dando ensejo a novas formas de organização da produção, bem como da vida social e política. A este conjunto de processos alguns autores deram o nome de acumulação flexível.

Antunes (1995) fez uma apresentação de diferentes abordagens sobre o tema: afirmou que Sabel e Piore (1984) foram considerados pioneiros nas teses sobre especialização flexível, e argumentaram favoravelmente em relação a esta nova forma produtiva e , na sua opinião, este processo superou o padrão fordista, considerado por eles como prejudicial ao trabalho e a sua expressão criativa.

Já Coriat (1992 b), crítico do modelo apresentado pelos autores acima, afirmou que ele é impossível de ser concretizado e na prática fica extremamente difícil imaginar sua generalização. Outro autor que também argumentou contra este modelo é Clarke (1991), porque acreditava que o modelo da especialização flexível é impossível de ser aplicado, pois traz incoerências e teve como resultado a intensificação do trabalho, além de ser um meio para a sua desqualificação e desordenação. Annunziato (1989) afirmou que o fordismo ainda domina a economia norte - americana pois apresenta um processo taylorista 
de produção, além de o capitalismo ser dominante, mesmo dentro de organizações sindicais.

Harvey (1993) informou que o núcleo essencial do fordismo permaneceu até 1973, quando a crise promoveu um movimento intenso de transição no interior do processo de acumulação do capital. Ele reconheceu a existência de uma combinação de sistemas produtivos articulando o fordismo com processos flexíveis, artesanais e tradicionais. Ou seja, ainda é forte a influência do fordismo, mas existem mudanças importantes na produção.

Porém, conforme apontou Antunes (1995), apesar da acumulação flexível, foi o toytismo ou o modelo japonês que trouxe maior impacto de transformação, tanto no sentido da revolução tecnológica, quanto na influência mundial sobre os modos de produção.

Coriat (1992 b) apresentou quatro fases importantes para o advento do toyotismo, quais sejam: a introdução na indústria automobilística da multifuncionalidade do trabalhador, ou seja, um operário manuseia mais de uma máquina; possibilidade do aumento da produção, sem o aumento da quantidade de mão de obra; introdução do kanban que era um método já utilizado em supermercados de reposição de mercadorias somente quando necessário; expansão dessa técnica (kanban) para empresas subcontratadas e fornecedores.

Com o toytismo ficaram conhecidos processos como: JIT - Just in Time - sistema que objetiva a redução total de perdas ou desperdícios, trata-se de um método de gestão por estoques; SMED - Single Minute Exchange Die - sistema produtivo que permite a troca de moldes nas prensas em questão de minutos, tornando possível a produção de pequenos lotes de produtos diferenciados; CWQC - Company Wide Quality Control - que é o chamado Programa de Qualidade Total.

Desta forma, quanto à organização do trabalho, o operário, para se tornar polivalente, passa a ocupar na fábrica diversos postos de trabalho, havendo sempre o 
predomínio do grupo sobre o indivíduo. O modelo japonês, pela sua competência em relação à produtividade, extrapolou as fronteiras de seu país, sendo utilizado como base por muitas empresas ocidentais.

Outros modelos administrativos de redução dos custos e aumento da produtividade que vêm sendo implementados, até pouco tempo atrás com maior intensidade, são a reengenharia e o downsizing que no fundo têm objetivos semelhantes, mas com aplicações diferenciadas.

A reengenharia é o repensar fundamental e a reestruturação radical dos processos empresariais que visam alcançar melhorias drásticas em indicadores críticos e de desempenho. A empresa passa a atuar com equipes multidimensionais, fundamentadas na tecnologia. Tem como ponto positivo a busca pela visão global dos processos empresariais e sua integração. Mas na prática ocorre a desumanização da empresa: com o intuito de eliminar processos desnecessários, as pessoas são desconsideradas, não há valorização do trabalhador, desrespeitam sua experiência, o que acarreta um alto grau de desmotivação e insegurança.

O outro paradigma mencionado o downsizing tem como objetivo tornar a estrutura mais leve, eliminar todo o trabalho que não agrega valor, aproximar os níveis operacionais do nível estratégico. Suas principais ações são: descentralização e delegação; diminuição da estrutura; redução dos níveis gerenciais e corte de custos. Este modelo tem sua validade quando se pensa em excesso de burocratização dentro de uma estrutura empresarial. Mas as ações podem ser desastrosas para o trabalhador: demissões, sobrecarga de trabalho, confusão entre os níveis gerenciais.

Com estas explanações pode-se dizer que não existe uma tendência única para a categoria trabalho. $\mathrm{O}$ que se observa é uma processualidade complexa e heterogênea que propagou essas características também à categoria trabalhadores. Ainda não se pode afirmar que esta seja uma categoria em extinção porque, apesar da grande diminuição dos postos de trabalho, o capital se utiliza dos trabalhadores de maneiras diferenciadas. Em resumo, o 
mundo do trabalho ultrapassou as situações rudimentares, chegando à automação, tornando complexa a sua administração. E é nesse contexto que está inserido o trabalhador no tempo atual, lugar onde associam-se interesses que nem sempre estão a seu favor. Interesses que se diluem na vivência do cotidiano, que é voltado para a sobrevivência. A melhoria da qualidade de vida para a "classe que vive do trabalho" é na verdade tornar o trabalho um meio de realização pessoal, onde o trabalhador possa realmente se sentir útil e criador.

Estas considerações são importantes pois permitem compreender, de maneira geral, em que contexto está inserido o trabalhador no mundo atual. Este estudo analisa uma categoria específica que é o bancário, que adoeceu no exercício de seu trabalho e, após afastamento precisa retomar suas atividades profissionais, porém apresentando restrições que o impedem de retornar às atividades anteriormente exercidas.

Algumas questões se colocam nesta situação: como é a reabilitação profissional no banco estudado? Como é vivenciada esta realidade pelo trabalhador? O que dificulta e o que contribui para o retorno ao trabalho? Como retomá - lo ? Para a compreensão deste processo é importante a apresentação de alguns temas, quais sejam: automação bancária; LER (Lesões por Esforços Repetitivos) e reabilitação profissional.

\subsection{A automação bancária no Brasil}

Os primeiros bancos surgiram ainda no século XIX, mas é no século XX que ocorreram grandes mudanças tecnológicas e nas relações de trabalho. No Brasil, especificamente em São Paulo, em meados da década de 1920 foi intensificada a criação de bancos, cujos proprietários vinham da aristocracia rural paulista e estabeleciam suas próprias normas de serviço. A relação de trabalho era de total dominação dos banqueiros sobre seus trabalhadores. 
Conforme relatou Segnini (1998), não havia máquinas de calcular, a contabilidade era feita manualmente e o trabalhador deveria ficar no trabalho até que todas as contas estivessem conciliadas. Acrescenta a autora que as alterações sofridas durante o século XX se deveram à dinâmica imposta pelas relações entre o capital e sua reprodução. A partir da década de 1930, com a política econômica estabelecida por Vargas, o Estado passou a proteger a expansão do capital. Desta época até os primeiros anos da década de 60 , foram introduzidas as primeiras máquinas para registros bancários e então ocorreu o processo de divisão das funções.

As mudanças tecnológicas nos bancos acompanharam o contexto econômico do país, tendo sido intensificadas a partir de 1960. O golpe militar de 1964 significou a aliança entre o poder político e uma parte da burguesia nacional para incremento e expansão do capital. Em estudo feito por Ely (1993 ) foram identificados três momentos importantes quanto aos serviços bancários no Brasil: o primeiro compreende os anos entre 1964 a 1970; o segundo tem seu início ainda em 1970 e vai até 1980; e o terceiro, no final dos anos 80 com a introdução da automação como ela é atualmente conhecida.

O primeiro momento se deu a partir da política do governo militar em 64 procurando centralizar e concentrar o capital no país. Com o objetivo de controlar a situação financeira, foram criados nessa época os Centros de Processamento de Dados, viabilizados através do uso de computadores de grande porte.

Para tanto, conforme relata Segnini (1998), foram criados instrumentos legais como a Reforma Bancária (Lei 4595, de 31/12/64), a Reforma do Mercado de Capitais (Lei 4728 de 14/07/65) e o PAEG - Plano de Ações do Governo (1964 - 1966). Os bancos passaram nessa época a centralizar serviços comerciais, de investimentos, administração de carteiras e fundos de ações, leasing, sociedade de créditos imobiliários, corretoras, seguradoras e distribuidoras.

Nessa época também foi criado o Banco Central do Brasil em 1967, cujo objetivo era a normatização e padronização dos serviços bancários. Modificaram-se também as 
relações de emprego no setor, através da subcontratação por tempo determinado, terceirização de serviços, informatização e admissão de mulheres no setor. Toda esta mudança refletiu o esforço dos bancos em otimizar o atendimento, diversificando a carteira de clientes, maximizando os lucros.

Assim, teve início o segundo momento identificado por Ely (1993) com a introdução do sistema on line, criando-se formas de apoio às decisões e implantados terminais de consulta a clientes. Contribuiu para tanto o contexto econômico entre 1970 1980, período em que o Brasil passava por uma crise inflacionária.

O terceiro momento identificado por Ely (1993) teve relação com a intensificação da automação bancária, uma estratégia das instituições financeiras frente às inovações do mercado. No final dos anos 80 foram introduzidas ações inovadoras nos serviços bancários: criação de agências virtuais; implantação de ATM (Automatic Teller Machine) que são os caixas eletrônicos; cartões magnéticos; atendimento de clientes em casa ou no trabalho; criação de "Bancos de Bolso", que são microcomputadores portáteis; integração entre bancos e comércio, com a utilização de cartões magnéticos; compensação eletrônica e leitura ótica de cheques; interligação de rede entre bancos e empresas.

Para os bancos a automação permitiu: aumento da atuação no mercado financeiro, possibilitando aos gerentes um melhor atendimento, mais segurança nas operações financeiras, maior efetividade nas aplicações, com agilidade e confiabilidade das informações. Além disso, a automação proporcionou a redução de custos com mão - de obra, pois dirimiu as tarefas de contabilidade e compensação, reduzindo também custos operacionais.

A tecnologia possibilitou o aparecimento do banco virtual. O cliente não precisa ir à agência para efetuar seus pagamentos, recebimentos e aplicações. Este tipo de atendimento é complementado pelos serviços do chamado courrier, que nada mais é do que um office boy. Outra estratégia adotada pelo bancos, a partir do fracasso do Plano Cruzado, foi a de investir na captação de recursos de grandes investidores e para tanto deram início a diversas 
ações: mudança de lay out, passando este a ser padronizado e direcionado para o atendimento da clientela que foi segmentada a partir de seu rendimento, implantação de um sistema de informações sobre os clientes que foi colocado nas mesas dos gerentes, que possibilita um atendimento mais rápido e adequado ao perfil do cliente, os setores de retaguarda foram diminuídos e em alguns casos eliminados, os clientes de pequenos e médios depósitos tiveram que ser educados para utilizar os serviços de atendimento, com o objetivo de diminuir as filas nos guichês dos caixas, deixando espaço para o "negócio".

Pagotto (1996) apresentou um balanço a respeito da automação bancária: “O número de agências no sistema como um todo passou de 20.000 em 90 para $16.800 \mathrm{em} 92$. O número de empregados por agência reduziu-se em 10\%, segundo relatório do DIEESE sobre desempenho dos bancos privados em 1992. Ao mesmo tempo, de acordo com a FEBRABAN, o número de transações automatizadas pulou de 19,5 milhões em 91 para 25 milhões em 92. O mesmo ocorreu com os caixas eletrônicos que aumentaram de 1578 para 2000 em 92.".(p.226)

Desta forma, a automação imprimiu grandes modificações na categoria bancária. Se por um lado diminuiu postos de trabalho, por outro introduziu novas tarefas ligadas à informática, aumentando o controle e a mecanização do trabalho. A introdução de novas tecnologias gerou alterações na organização do trabalho, a qual tomou um rumo diferenciado, além de transformar as exigências para os trabalhadores. Quando teve início o trabalho bancário, o trabalhador deveria ter boa caligrafia, pois a atividade era essencialmente escrita, além de ter boa noção de contabilidade. $O$ bancário agora tem que ser um multiprofissional que, além de compreender finanças e contabilidade, deve saber lidar com as novas tecnologias.

Romanelli (1978) apresentou a seguinte definição do perfil do trabalhador bancário: “...anteriormente os atributos definidores do bom bancário encontravam-se fora da empresa, em certo grau de escolaridade e na familiaridade com regras formais de relações interpessoais, dependentes da posição de classe, e da honradez, algo que se possuía independente de classe e que trazia para o interior do estabelecimento. Atualmente, os 
traços característicos do bom empregado encontram-se no seio da empresa, vinculados ao montante de tarefas executado e ao rendimento de cada um.".(p.161)

Izumi (1997) traduziu o novo perfil do trabalhador bancário da seguinte maneira: “A utilização da tecnologia bancária foi direcionada para a redução de postos de trabalho convencionais, propiciando a evolução de diversificação de atividades comerciais tais como a gestão e emissão de cartões de crédito, seguros, previdência privada, títulos de capitalização, etc; para compatibilizar a qualificação dos bancários a essas novas atividades passou-se a exigir, recentemente, requisitos funcionais voltados à venda de produtos e serviços financeiros." (p.69)

O processo de ascensão profissional dentro do banco está relacionado com o aspecto quantitativo, ou seja, quanto maior a quantidade de trabalho (medida através do retorno financeiro) oferecida à instituição, maior a possibilidade de crescimento dentro do quadro gerencial.

Mas, se houve a introdução de tecnologia no sistema bancário que acabou por diminuir o tempo gasto com operações financeiras, por que então sobram tarefas?

Segundo a tendência mundial, os bancos procuraram modificar o atendimento e se concentrar na realização de negócios. Assim a introdução da tecnologia bancária foi direcionada para a diminuição de postos de trabalho, como por exemplo, os caixas. E ao mesmo tempo deu espaço para a diversificação das atividades como a administração de cartões de crédito, seguros, previdência privada, títulos de capitalização e tantos outros produtos. E mais ainda, os bancos estão atuando também na área de consultoria.

É neste sentido que aumentaram as tarefas dentro do setor bancário e estão atingindo diretamente o trabalhador. Estudos feitos pelo DIEESE (1997) demonstram algumas modificações ocorridas no perfil do bancário:

- Aumento do número de empregados com cargos gerenciais a partir de 1988; 
- Diminuição dos postos de chefia intermediária e das funções de escriturários e auxiliares;

- Intensificação da participação das funções de caixa, considerando a sua redução em quantidade de postos, e a necessidade de redução do tempo de espera para atendimento de clientes nas agências;

- Continuidade dos processos de subcontratação e terceirização de algumas atividades como manutenção, vigilância, recepção, telefonia, apoio e secretaria.

Um estudo realizado pelo Instituto Nacional de Saúde no Trabalho/CNB/CUT (1993) indicou que o perfil da atividade bancária sofreu alterações intensas a partir da introdução da automação, apresentando como principais mudanças: “... o ritmo de trabalho e sua carga intensificam-se; à função do caixa, por exemplo, é prescrita uma nova tarefa, a de "vendedor de capital"; ocorre um empobrecimento do conteúdo da tarefa; restringem-se e desqualificam-se as relações sociais no trabalho; a retaguarda praticamente desaparece; e, principalmente, despersonifica-se o processo de controle do trabalho bancário.” (pg. 59)

Complementando estes dados o estudo apresentou um trabalho escrito por Blass (1989), em que a autora discutiu a expropriação do saber do bancário, herança da automação: "As transformações ocorridas no processo de trabalho bancário pressupõem também um gradativa expropriação do saber técnico dos trabalhadores, modificando a própria visão e conteúdo do trabalho executado. Assim, se ontem trabalhar em bancos significava exercer uma espécie de ofício para o qual se exigia o domínio de conhecimentos em contabilidade, hoje, à medida que eles estão incorporados às máquinas automáticas, o saber e a iniciativa estão subtraídos da maioria dos trabalhadores, que devem demonstrar habilidade no manejo dessas máquinas, rapidez nos gestos corporais e destreza manual na execução de tarefas rotineiras." (pg. 60)

Lima (1998) realizou investigação entre bancários, em que esses trabalhadores citaram a automação como um determinante no adoecimento por LER desta categoria, associando o aumento do número de casos com a época de implantação dessa forma de 
organização do trabalho, isto porque ocorreu uma intensificação do trabalho, por exemplo: o caixa passou assumir tarefas que antes eram realizadas por outros setores, como as de digitação.

Atualmente é exigido do trabalhador bancário ser um profissional capaz de atuar como consultor financeiro, além de promover a venda de produtos e serviços bancários. $\mathrm{Ou}$ seja, foi descaracterizado em pouco tempo um papel que foi historicamente construído. Ainda pode-se pensar que os bancários normalmente são pessoas que concluíram um curso superior na escolaridade, tendo sido preparados para ocuparem cargos de decisão e autonomia e acabam se transformando em meros reprodutores de instruções, atuando sob o poder das máquinas e das decisões da alta administração.

Este fator, acrescido do aumento da carga de trabalho, tem sido determinante em muitos casos no adoecimento do trabalhador, conforme estudo realizado por Silva (1991) em que foram apresentadas como queixas de saúde: reclamações generalizadas de estresse, nervosismo, ansiedade, gastrite, sem contar com a tensão e dor de cabeça crônicas.

Portanto, a automação trouxe uma diminuição de muitas tarefas rotineiras, porém sobrecarregou o trabalhador bancário com uma série de outras responsabilidades, além de tirar sua autonomia de decisão.

\subsection{As LER - Lesões por Esforços Repetitivos em bancários}

Tendo em vista que o presente estudo esteve voltado para um grupo específico de doenças que foram as LER, foi considerada importante a apresentação de alguns pontos relacionados ao tema, que identificam o conceito adotado, diagnóstico e principais bibliografias. Não foi o caso de aprofundamento no tema, porque o objetivo deste trabalho se concentrou na reabilitação profissional de trabalhadores com estas doenças. 
A definição de LER adotada, foi a da Secretaria de Estado da Saúde de São Paulo por ser a denominação utilizada pelos trabalhadores entrevistados ao se referirem ao seu processo de adoecimento. Segundo a Secretaria, a "LER é um conjunto de afeç̧ões que podem acometer tendões, sinóvias, músculos, nervos, fáscias e ligamentos, isolada ou associadamente, com ou sem degeneração de tecidos, atingindo principalmente, porém não somente, os membros superiores, região escapular e pescoço, de origem ocupacional, decorrente, de forma combinada ou não, de uso repetitivo de grupos musculares, uso forçado de grupos musculares, manutenção de postura inadequada."(Norma Técnica para LER, 1992)

No Brasil, a partir de 1985 intensificaram-se as publicações e debates decorrentes da pressão do movimento social dos profissionais de processamento de dados que resultaram na publicação em 1987 da Portaria $n^{\circ} 4062$ do Ministério da Previdência e Assistência Social reconhecendo a tenossinovite como doença do trabalho. (Rocha, 1989)

Posteriormente foram registrados casos em várias categorias profissionais, sendo crescente este quantitativo. O INSS (Instituto Nacional de Seguridade Social) em sua estatística a respeito de acidentes de trabalho, quanto ao CID - Código Internacional de Doenças - informou que a maioria dos casos registrados de doenças do trabalho são aquelas relacionadas com as LER (tenossinovite e sinovites; dorsalgias; lesões no ombro; endopatias; etc/ Dados do site do Ministério da Previdência - INSS - 2003).

Atualmente os trabalhadores com o diagnóstico de LER fornecido pela rede de assistência médica, procuram as empresas para o preenchimento da CAT (Comunicação de Acidente de Trabalho) e início do processo de análise, geralmente solicitando afastamento do trabalho.

É importante citar as dificuldades quanto ao correto estabelecimento do diagnóstico. Por exemplo, o estudo feito por Helfenstein Junior (1997) em que o autor procurou verificar a existência de fibromialgia entre pacientes diagnosticados como portadores de LER. Ele examinou 103 pacientes e, entre estes, dos 80 que apresentavam dor difusa, 73 
foram comparados clinica e psicologicamente com 165 pacientes fibromiálgicos e os resultados foram bastante similares. $\mathrm{O}$ autor afirmou que muitos pacientes diagnosticados como portadores de LER são, na verdade portadores de fibromialgia.

Nesse estudo não foi analisado o diagnóstico dos trabalhadores, mas sim os aspectos relacionados ao processo de reabilitação profissional.

É vasta a literatura existente sobre LER, porém uma vez que este estudo esteve voltado para a categoria dos bancários, foram verificadas as publicações feitas a esse respeito. Em nível internacional, Yu e Wong (1996) estudaram distúrbios osteomusculares entre trabalhadores que usavam o VDU (visual display unit) em um banco em Hong Kong. A prevalência de queixas foi de: $31,4 \%$ no pescoço ; $30,6 \%$ nas costas; $16,5 \%$ nos ombros; $14,9 \%$ nas mãos e punhos e $6,6 \%$ nos braços. Os trabalhadores que se utilizavam freqüentemente do VDU apresentavam mais problemas músculo - esqueléticos do que aqueles que o utilizavam esporadicamente. As queixas individuais foram associadas com os seguintes fatores de risco: características pessoais, postura inadequada, movimentos repetitivos e desenho incorreto do posto de trabalho. Os autores recomendaram modificações no posto e na organização do trabalho para redução destes distúrbios.

No Brasil Jackson Filho (1993) avaliou a incidência de LER nos setores de compensação bancária e de processamento de dados em um banco estatal em Florianópolis - Santa Catarina. Trata-se de um laudo pericial realizado pela FUNDACENTRO/SC entre os meses de setembro a novembro/93. O autor afirmou que a organização do trabalho incompatível com as capacidades psicofisiológicas das pessoas, além da intensificação do trabalho, resultou em niveis elevados de adoecimento, especialmente por LER. A conclusão do autor nesse trabalho foi a de que são péssimas as condições gerais de trabalho (ambiente e organização), além da ineficiência do gerenciamento dessa situação por parte da empresa.

Ferreira Jr, Conceição e Saldiva (1997) publicaram artigo sobre uma pesquisa realizada entre trabalhadores de telemarketing de um banco internacional com uma filial em São Paulo. O objetivo foi verificar fatores de risco para o desenvolvimento de distúrbios 
osteomusculares dos membros superiores entre estes trabalhadores. Os resultados mostraram uma associação entre os distúrbios e a pressão do tempo, juntamente com as normas internas de trabalho. As características do posto, equipamento, postura corporal e esforço muscular não foram estatisticamente associados.

Chaves et al (1998) publicaram um estudo epidemiológico realizado entre 296 trabalhadores de uma agência bancária e um Centro de Processamento de Serviços e Comunicações de um banco estatal localizado na Bahia, no período de julho/93 a julho/94. O objetivo foi estudar as relações existentes entre a saúde dos bancários e a organização do trabalho. Nos resultados foi ressaltado que as queixas relacionadas à saúde são menores nos locais onde as queixas com relação à organização do trabalho são em menor quantidade. Foi destacada também a solidariedade entre os colegas como fator de proteção.

Um outro estudo feito por Lima (1998) discutiu os resultados de reuniões realizadas entre bancários divididos em dois grupos, um deles com pessoas portadoras de LER e o outro com pessoas sem este diagnóstico, visando conhecer as formas de proteção utilizadas para não adoecerem.

No primeiro grupo foram apontados os principais fatores presentes na gênese da LER, quais sejam: a automação, citada pela maioria dos caixas como um marco para o aumento do número de casos; o horário de trabalho, isto porque o horário de seis horas como é o acordado em lei, não é a realidade da jornada diária; as condições de trabalho tais como ruído, baixas temperaturas, mobiliário e maquinário inadequados não favorecem o desenvolvimento das tarefas; intensificação do trabalho, critérios de avaliação, responsabilidade excessiva, características pessoais, impossibilidade de realização profissional; mudança nas políticas, planos econômicos que acarretam mudanças nos bancos.

Quanto às diferenças entre os dois grupos, o segundo grupo (não portadores de LER) apresentou : maior disponibilidade para mudar ou diversificar as atividades; a relação com o trabalho e as exigências pareciam ser diferentes, esse grupo pareceu escolher não 
acelerar o seu ritmo, nem ultrapassar a jornada de trabalho; a relação com a avaliação também mostrou ser diferente, esse grupo preferia a qualidade do atendimento ao invés da quantidade; esse grupo mostrou também ter uma capacidade maior de descontração. A autora fez uma recomendação a partir de suas pesquisas: a mudança deve ocorrer na organização do trabalho e não nas pessoas.

Ribeiro (1999) apresentou o papel do Estado e da medicina do trabalho como instituições responsáveis pela normatização e intervenção nas questões deste e de outros tipos de adoecimento dos trabalhadores. Analisou a "violência oculta" na atividade bancária e a emergência das LER nesses trabalhadores, descrevendo o percurso do adoecimento coletivo baseado nos depoimentos de 346 bancários portadores de LER, tendo como principal resultado a revelação feita pelos sujeitos de sentimentos de perda e medo da incapacidade, além do esforço para aceitar novos limites e a vontade de retornar ao trabalho para evitar a discriminação e marginalização social e afetiva.

Borges (2000) realizou estudo entre caixas de um banco estatal na região da grande Vitória/ES com o objetivo geral de "estabelecer relações de determinação entre o trabalho de caixa bancário, LER e sofrimento psíquico." (pg. 176) Os dados foram obtidos a partir de diversos instrumentos (questionários, observação participante, abordagem grupal e dinâmicas) e a população total foi de 277 caixas. Em seus resultados o autor apresentou o índice de $59 \%$ dos caixas relatando algum problema de saúde nos últimos 6 meses que necessitaram de atendimento médico ou uso de medicamentos. Dentre as situações de adoecimento destacaram-se as LER e a dor na coluna.

Outro estudo de Marofuse e Marziale (2001) analisou as mudanças no trabalho e na vida dos bancários de uma Associação de Portadores de LER em Cascavel, Paraná. Foram indicados como principais elementos do processo de adoecimento: incremento da carga de trabalho, uso de computadores, realização de horas extras, ausência de intervalo, monotonia, tarefas repetitivas, trabalho intenso e controle da produtividade, pressão e tensão. 
Pelos estudos apresentados pode se perceber a complexidade que envolve a questão das causalidades das LER. Não se pode reduzi-la a um simples problema de repetitividade ou de equipamentos e mobiliário. As LER ultrapassam a materialidade das tarefas e das condições de trabalho, alcançando a dimensão psicossocial, onde encontram-se as relações profissionais que acabam interferindo na vida privada.

Em virtude disso e, como este estudo esteve voltado para o identificação de aspectos psicossociais, é importante uma breve apresentação do seu conceito.

Uma abordagem especialmente importante foi realizada pela Organização Mundial da Saúde em que foram introduzidas por Levi (1987) algumas definições nesta área. O autor iniciou sua redação explicando que os estímulos psicossociais têm sua origem a partir do processo social que ocorre dentro de uma estrutura social (empresa, escola, comunidade ou família). Por sua vez o homem se caracteriza por um programa psicobiológico individual, com uma propensão para ação e reação dentro de um determinado padrão.

Ocorre que quando as necessidades individuais não são satisfeitas, ou quando as habilidades estão acima ou abaixo da situação presente, o organismo reage através de mecanismos patogênicos. Estes mecanismos podem ser cognitivos, emocionais, comportamentais ou psicológicos e, sob algumas condições de intensidade, freqüência ou duração, e na presença ou falta de certas variáveis, são precursores de adoecimento.

Estes mecanismos precursores de adoecimento podem ser descritos como mal funcionamento dos sistemas físico ou mental que ainda não resultou em doença, mas o fará se for contínuo. De outra maneira a saúde pode ser entendida como um estado de bem estar que está relacionado a uma condição dinâmica de equilíbrio entre habilidades, necessidades e expectativas de um lado e demandas ambientais do outro. Portanto todo o segmento acima descrito se traduz em uma ação que repercute na estrutura e no processo social, é um ecossistema que é influenciado e influencia toda a estrutura. 
Kalimo (1987) observou que os fatores psicossociais foram reconhecidos por serem aspectos críticos tanto na causa e prevenção de doenças, quanto na promoção da saúde, ou seja, não são somente causa de doenças profissionais, mas também são determinantes na saúde dos trabalhadores.

Outra definição importante foi a divulgada através da ILO - International Labour Organization - (1984) onde os fatores psicossociais no trabalho referiam-se à "interação entre ambiente de trabalho, conteúdo do trabalho, condições organizacionais e capacidades dos trabalhadores, necessidades, cultura, vida fora do trabalho, que podem, através das percepções e experiência, influenciar a saúde, o desempenho e a satisfação no trabalho."

No mesmo documento, aprofundando o conceito, foram abordadas as possibilidades de haver ou não um equilíbrio entre o ambiente de trabalho e as necessidades humanas. Assim o sucesso da interação mencionada é determinado pelas possibilidades e limitações humanas que são dadas pelos fatores psicológicos e biológicos, bem como por características pessoais e o contexto social. Quando existe harmonia entre estes fatores humanos $\mathrm{e}$ as condições de trabalho, existe também o sentimento de domínio e autoconfiança que aumenta a motivação, a capacidade e a satisfação, trazendo conseqüências benéficas para a saúde do trabalhador. Ocorrendo o inverso, existindo um desequilíbrio entre os fatores humanos e as demandas do trabalho, reações diversas se fazem presentes nos vários níveis biológico, psicológico, comportamental e social. $\mathrm{O}$ resultado disso depende da capacidade do indivíduo de superar ou não a situação que se apresenta e, isso varia de pessoa para pessoa.

\subsection{A Reabilitação Profissional}

A Reabilitação Profissional consta como objetivo da Assistência Social nos incisos III e IV do art. 203 da Constituição de 88, que ampliou o direito a quem dela precisar, independentemente da contribuição à seguridade social. Conforme art. 899 da Lei 8213/91 
este atendimento foi estendido às pessoas portadoras de deficiência, mesmo sem vínculo com a Previdência Social.

A assistência social em termos estruturais pertence ao Ministério da Previdência e Assistência Social, que se vê responsabilizado a dar tratamento adequado à Reabilitação Profissional, como parte da promoção social e do equilíbrio atuarial. Este equilíbrio está mencionado no art. 201 da Emenda Constitucional $\mathrm{n}^{\circ} 20$, em seu caput, onde existe a observação de "critérios que preservem o equilíbrio financeiro e atuarial".

Além da legislação acima mencionada, o governo brasileiro através do Decreto $\mathrm{n}^{\mathbf{o}}$ 129 de 22/05/91 promulgou a Convenção 159 da OIT (Organização Internacional do Trabalho) de 01/06/83 sobre a Reabilitação Profissional e o Emprego de Pessoas Deficientes e as Recomendações 99 e 168, tendo estabelecido as Normas Internacionais do Trabalho sobre a Readaptação - Diretrizes para a sua Aplicação.

A Recomendação 99 estabelece que "a expressão adaptação e readaptação profissionais designa aquela parte do processo contínuo e coordenado da adaptação e readaptação profissionais à aplicação de meios - especialmente orientação profissional, formação profissional e colocação seletiva - para que as pessoas incapacitadas possam obter e manter um emprego adequado; o termo pessoa incapacitada significa toda pessoa cujas possibilidades de obter e manter emprego adequado se encontrem realmente reduzidas devido a uma diminuição de sua capacidade física ou mental."

Para o INSS , que no Brasil é o órgão responsável pela reabilitação profissional, trata-se de um serviço colocado à disposição dos segurados, inclusive aposentados e dependentes, que tem como objetivo "proporcionar aos segurados e dependentes incapacitados (parcial ou totalmente) os meios indicados para a (re) educação e (re) adaptação profissional e social, de modo que possam voltar a participar do mercado de trabalho." (MPAS 642001 ) 
As funções básicas de reabilitação profissional foram determinadas com a publicação do Decreto $n^{\circ} 2172 / 97$ e da Resolução/INSS/PR n ${ }^{\circ} 424 / 97$ quando foram assim definidas:

- Avaliação de capacidade laborativa residual que consiste no processo de análise global das limitações; perdas funcionais e aquelas funções que se mantiveram conservadas; habilidades e aptidões; potencial para aprendizagem; experiências profissionais e situação empregatícia; nível de escolaridade; faixa etária e mercado de trabalho de origem, com vistas à definição da capacidade real de trabalho dos beneficiários.

- Orientação e acompanhamento da programação profissional que consiste no processo de condução do reabilitando à escolha consciente e esclarecida da atividade a exercer no mercado de trabalho, mediante conjugação de três elementos básicos: o conhecimento de sua capacidade laborativa, dos requisitos necessários ao exercício das profissões e das oportunidades oferecidas pelo mercado de trabalho, bem como o planejamento da sua profissionalização.

- Articulação com a comunidade para reingresso no mercado que consiste no conjunto de ações dirigidas ao levantamento de tendências e oportunidades oferecidas pelo mercado de trabalho, preferencialmente, na localidade de domicílio do reabilitado com vistas ao seu reingresso.

- Acompanhamento e pesquisa de fixação no mercado de trabalho que consiste no conjunto de ações para constatar o ajustamento do reabilitado ao trabalho, a efetivação do processo reabilitatório e a obtenção de dados que realimentem o sistema gerencial, visando a melhoria do serviço.

No momento atual a estruturação da reabilitação profissional dentro da Previdência Social vem sofrendo alterações, que ainda não se encontram totalmente definidas. Porém desde 1995 a Divisão de Reabilitação Profissional vem procurando consolidar mudanças, elaborando inclusive um Plano de Modernização da Reabilitação Profissional. No organograma do INSS, ligados à Superintendência estão as Gerências de Benefícios de Incapacidade - GEBENIN que estão encarregados de administrar as diversas Agências do 
INSS que possuem perícia médica, as chamadas APS - Agência da Previdência Social. Fazendo parte de cada uma destas APS, estão os profissionais da reabilitação profissional.

O novo enfoque da Previdência com relação aos benefícios de incapacidade é que perícia e reabilitação devem sempre caminhar juntas, no sentido de diminuir o tempo das licenças, buscando otimizar o retorno ao trabalho daqueles segurados que foram afastados do trabalho, havendo ou não seqüelas. Assim, os médicos - peritos estão recebendo nova orientação: agora além de estabelecer o nexo causal e a incapacidade ou não para o trabalho, também estão sendo treinados para o estabelecimento da capacidade laborativa e avaliação das restrições para o desempenho das tarefas no trabalho.

As resoluções n's 720 e 960 de 24/04/96 e 25/06/97 ratificaram algumas diretrizes no sentido de buscar a otimização dos serviços como busca de parcerias internas e externas; descentralização e ampliação da rede de atendimento com a criação de Unidades de Extensão e o incentivo à utilização de Equipes Volantes; criação de um sistema de informações para melhor acompanhamento e avaliação dos resultados e a divulgação da Reabilitação Profissional na busca de recursos da comunidade necessários ao alcance de seus objetivos.

Considerando que este estudo esteve voltado para a reabilitação em banco, a informação que se tem a respeito deste tipo de atividade, é que o INSS também repassou para estas instituições a responsabilidade pelo processo. Assim, na maioria dos bancos é a área de saúde ocupacional que se encarrega do retorno ao trabalho dos empregados que se afastam por doença do trabalho. Os técnicos procuram encontrar o posto mais adequado às restrições estabelecidas pelo INSS. No caso do banco estudado, o processo de retorno é acompanhado através de um Programa que está descrito no item Resultados.

$\mathrm{Na}$ literatura, Straaton et al (1995) realizaram estudo com o intuito de avaliar o acompanhamento do Serviço de Reabilitação Ocupacional do Alabama - USA - entre 1987 a 1991 e foram identificados como fatores predisponentes ao retorno ao trabalho ser ou não 
beneficiário de seguridade social e nível de escolaridade. A gravidade da doença não foi associada com o retorno ao trabalho.

Noreik e Grunfeld (1995) avaliaram um programa de reabilitação coordenado por um escritório regional da seguridade social na Noruega. Os autores fizeram um acompanhamento de 103 pacientes, na maioria mulheres, com diagnósticos psiquiátricos e de síndrome de dor músculo - esquelética, que estavam em processo de reabilitação. No final de 3 anos, obtiveram como resultado: $84 \%$ destes pacientes ainda se encontravam em reabilitação médica e recebiam beneficios; $8 \%$ haviam recebido uma aposentadoria por invalidez e apenas $4 \%$ se encontravam independentes do sistema de seguro social. A conclusão foi de que esse sistema não tem funcionado por causa de uma falta de planejamento e implementação sistemática de medidas mais adequadas de reabilitação médica e profissional. Além disso, o mercado de trabalho também deve realizar um esforço no sentido de proporcionar mais empregos a estas pessoas.

Nos anais do $13^{\text {th }}$ Trienal Congress of the International Ergonomics Association, Tampere, Finland , 1997 consta o volume 4 que versa sobre temas em LER e reabilitação. Muitos dos estudos em reabilitação estão voltados para a adequação ergonômica dos ambientes dentro e fora do trabalho, visando à melhoria da qualidade de vida dos portadores de deficiências. Nas considerações teóricas e vocacionais, Gard e Sandberg ${ }^{34}$ (1997) apresentaram um estudo feito na Suécia entre pacientes com LER que retornaram ao trabalho após 12 semanas em um programa de reabilitação. A conclusão a que chegaram é que o relacionamento interpessoal é o fator de motivação mais importante, inclusive aumentando o nível de autoconfiança destes trabalhadores que estão retornando ao trabalho após longo período de afastamento.

Nordstrom e Moritz (1998) realizaram estudo sobre um projeto de cooperação técnica entre o Hospital Universitário Lund (Suécia) e a Unidade de Saúde Ocupacional para reabilitação de 34 empregados do Hospital com diagnóstico de LER, tratados por uma equipe multidisciplinar, utilizando testes e avaliações para dor, índices de saúde e qualidade de vida. Este grupo foi comparado a um grupo referência composto por 57 sujeitos 
submetidos à reabilitação profissional da Unidade de Serviço de Saúde Ocupacional do Departamento Pessoal do referido hospital. Os grupos foram seguidos entre 2 a 4 anos, usando-se um questionário sobre as condições de trabalho e o nível de saúde. Houve uma significativa diferença entre os dois grupos: $77 \%$ do grupo de intervenção retornou ao trabalho com sucesso, enquanto somente $58 \%$ do grupo referência conseguiu este resultado, comprovando-se a eficácia do tratamento multidisciplinar.

Krause et al (1998) efetuaram pesquisa no sentido de elaborar um resumo estruturado a respeito da modificação no trabalho e o retorno ao trabalho. Durante dois anos (1996 a 1998) vários resumos foram enviados aos autores para análise e comentários, o objetivo era o de avaliar a estrutura, efetividade e eficácia de programas para modificação no trabalho. A conclusão dos autores foi que programas para modificação do trabalho facilitaram o retorno de trabalhadores incapacitados.

Ahlgreen e Hammarstron (1999) concretizaram estudo com o objetivo de determinar se os investimentos feitos na Suécia em reabilitação profissional aumentaram o nível de retorno ao trabalho. A população alvo foram os trabalhadores abaixo de 30 anos que relataram diagnóstico de LER nos escritórios de Seguridade Social em Vasterbetten entre 1990 a 1994 (266 pessoas). Os resultados da pesquisa demonstraram que esses trabalhadores estavam mais propensos a voltar ao trabalho durante a realização da reabilitação profissional. Os homens apresentaram maior grau de retorno, mesmo que as mulheres apresentassem nível maior de escolaridade.

Elders et al (2000) efetivaram revisão da literatura para avaliar a efetividade de programas de prevenção de LER durante prolongado afastamento do trabalho. Os autores pesquisaram artigos que tivessem grupos de intervenção profissional específico e grupos com tratamento tradicional. Após a pesquisa foram encontrados 12 artigos que obedeciam aos critérios de seleção, todos eles com informações quantitativas sobre os efeitos de intervenção ergonômica no retorno ao trabalho. Em 8 estudos a opção foi pela introdução de programas educacionais, combinados com condicionamento funcional e treinamento em serviço. Em 7 destes 8 estudos, o retorno ao trabalho foi significantemente melhor para o 
grupo com a intervenção profissional. A intervenção após 60 dias, na fase subaguda de dor, mostrou resultados mais promissores.

Karjalainen et al (2003) realizaram estudo através de uma revisão da literatura com o objetivo de determinar a efetividade da reabilitação através da abordagem biopsicossocial para trabalhadores adultos com LER. A reabilitação com abordagem biopsicossocial foi considerada aquela desenvolvida por médico, psicólogo, assistente social, enfermeiro do trabalho e fisioterapeuta especialista em saúde ocupacional, todos atuando em conjunto. Os artigos selecionados foram aqueles em que os pesquisadores utilizaram testes aleatórios controlados (RCTs) e prospectivos, além de testes controlados simultâneos (CCTs) em reabilitação biopsicossocial com trabalhadores adultos (18 a 65 anos) com diagnóstico de LER. Os resultados escolhidos deveriam abordar: intensidade de dor; nível global de saúde/doença; nível específico da doença; nível de qualidade de vida; habilitação para o trabalho; cuidados com a saúde e custos; satisfação com o tratamento. Os autores encontraram somente dois estudos que estavam de acordo com os critérios de seleção, quais sejam: Moore (1996) que registrou nível de dor através da escala visual análoga (VAS) tanto no grupo de intervenção, quanto no grupo controle; Spence (1995) concluiu que os resultados da intervenção biopsicossocial não foram mais efetivos do que os resultados do grupo - controle nas oito semanas de acompanhamento. Na conclusão os autores da revisão recomendaram novos estudos sobre o tema.

Guzmán et al (2003) publicaram revisão bibliográfica sobre reabilitação com abordagem biopsicossocial com pacientes portadores de dor crônica nas região lombar e ombros, pretendendo conhecer o seu efeito sobre dor, nível de emprego e qualidade de vida. Os critérios de seleção dos estudos foram testes que utilizaram grupo controle com trabalhadores adultos e incapacitados para o trabalho com a patologia acima mencionada, por mais de três meses. Os principais resultados apresentados foram de 10 testes (excluídos os testes da revisão acima mencionada) selecionados (1964 pacientes) em que havia forte evidência da eficácia do tratamento com abordagem multidisciplinar, realizada em conjunto com a recuperação funcional, melhorando níveis de dor e de função. Quanto à 
qualidade de vida não pôde ser avaliada, tendo em vista a pouca profundidade de estudos a esse respeito.

No Brasil, Schweller (1983) publicou os resultados obtidos num grupo de 45 pacientes encaminhados ao Centro de Reabilitação Profissional (CRP) - INSS em Campinas/SP por lesões da coluna decorrentes de acidente de trabalho: comentou as dificuldades tanto no tratamento, quanto na recolocação profissional. Além disso informou que o comprometimento no alcance de bons resultados de um programa de reabilitação profissional estava no grande intervalo de tempo entre o acidente e o encaminhamento ao CRP, provocando maior demora da recuperação do doente ou mesmo da possibilidade de reabilitá-lo.

Struffaldi $(1987$; 1994) realizou duas pesquisas no tema reabilitação profissional, ambas no serviço prestado pelo INSS (CRP). Na primeira, entrevistou médicos peritos acidentários, observando diferenças no conhecimento das normas e legislações que abrangem a reabilitação profissional; existe um treinamento, mas nem todos os médicos atualizavam seus conhecimentos, acarretando diferenças na condução da perícia médica, ou seja os beneficiários do INSS recebiam orientações e encaminhamentos diferenciados, mesmo apresentando situação idêntica de adoecimento. Na segunda pesquisa, a autora efetuou uma investigação entre os segurados procurando identificar suas características pessoais e profissionais e verificando seus conhecimentos e opiniões a respeito de: segurança no ambiente de trabalho, dos serviços prestados pelo CRP e de seus direitos previdenciários. Estudou 105 trabalhadores acidentados por meio de um questionário estruturado, encontrando como resultados: a maioria destas pessoas estavam há mais de 4 anos afastados do trabalho e demonstraram conhecer seus direitos previdenciários, mas não os serviços de reabilitação profissional a que estavam submetidos.

Oliver (1990) fez uma reflexão sobre a maioria das propostas de intervenção em habilitação e reabilitação da terapia ocupacional em que a visão do trabalho é aquela predominante na vida social, na qual são empregados o trabalho artesanal, que é desqualificado socialmente, ou então, o trabalho que repete a proposta taylorista, sem 
qualquer restrição. A autora afirmou que se faz importante a criação de formas alternativas a este modelo.

A FUNDACENTRO e o CRP/INSS buscaram em conjunto uma caracterização dos acidentes graves de trabalho em 1990 objetivando propor uma atuação conjunta e contínua dos agentes governo-empregado-empregador apresentando como resultados gerais: a maioria é do sexo masculino, até 41 anos de idade; a escolaridade não passava do primeiro grau completo e pertenciam ao setor secundário da economia. $\mathrm{O}$ acidente típico foi o mais observado, com lesões graves. A maior parte da amostra tinha pretensões de retornar ao trabalho, especialmente pela defasagem salarial entre o auxílio acidente e o salário pago pela empresa se estivesse na atividade produtiva. A maioria demonstrou interesse em retornar à empresa de origem. Este trabalho finalizou com a recomendação de que todos os envolvidos no processo produtivo se conscientizem da necessidade de ações de prevenção, bem como o incremento de estudos sobre acidentes de trabalho no sentido de fornecerem subsídios para uma atuação técnica e eficiente.

Haro (1998) publicou uma reflexão sobre o modelo de reabilitação profissional convencional, objetivando identificar o significado do acidente de trabalho e a conseqüente inserção previdenciária da trajetória de vida do trabalhador, além de examinar o modo como o Estado, através dos CRPs responde a esta demanda. Como resultado identificou a posição problemática do CRP entre a concessão de um beneficio e a consolidação de um direito e, propôs que a reabilitação profissional seja incorporada ao campo da saúde do trabalhador como uma de suas ações fundamentais.

Carvalho (1999) fez uma análise sobre o preparo do fisioterapeuta para atuar e intervir na área da reabilitação profissional. Para tanto solicitou aos departamentos de 20 cursos de fisioterapia no Estado de São Paulo as estruturas curriculares, obtendo resposta de 14 deles. Também foram pesquisados 14 fisioterapeutas que trabalham em serviço de reabilitação profissional em São Paulo. Como conclusão a autora informou que o fisioterapeuta não tem em sua formação o preparo para a abordagem e intervenção na área de reabilitação profissional. 
Maeno (2001), mais recentemente, realizou pesquisa no sentido de estudar o processo de reinserção no mercado de trabalho de desempregados com LER de uma indústria eletrônica em São Paulo. Utilizando metodologia qualitativa com base na teoria das representações sociais, concluiu que, na percepção dos trabalhadores, a ocorrência de LER e as repercussões físicas e psicossociais da doença tiveram profundo impacto em suas vidas. Com a interrupção da perspectiva profissional na ocupação original, a reabilitação e a adaptação para um novo cotidiano têm se dado às custas de apoio da rede familiar.

Takahashi e Canesqui (2003) realizaram pesquisa em reabilitação profissional no sentido de reconstruir o programa implementado pela equipe de LER do CRP - Campinas e avaliar seus resultados. O modelo de intervenção adotado contava com um modo de atenção integral e integrado, reconhecendo as dimensões físicas, emocionais, relacionais e sociais, procurando resgatar a autonomia dos adoecidos não só para o trabalho, como para a vida. Para tanto articulou reabilitação com prevenção, estabelecendo parcerias interinstitucionais, utilizando uma das cinco equipes de reabilitação profissional que atuavam no CRP - Campinas, contando com três assistentes sociais, um sociólogo, dois médicos, três psicólogos, dois fisioterapeutas e dois terapeutas ocupacionais. Como resultados obtiveram: a intervenção atingiu um grau de efetividade alta, quando alcançou $64 \%$ no resgate da autonomia da clientela atendida e, este efeito positivo levaram-nas a concluir que esse modelo foi capaz de aliviar o sofrimento de muitas pessoas, resgatando a capacitação funcional, emocional e social, ampliando o debate sobre o tema e contribuindo para o reconhecimento social dessa problemática no município de Campinas. 


\section{A SITUAÇÃO NO BANCO ESTUDADO}

\subsection{A automação bancária}

A automação no banco estudado seguiu os mesmos caminhos dos bancos de uma maneira geral. Trata-se de uma instituição financeira sob a forma de empresa pública, vinculada ao Ministério da Fazenda. Tem sede e foro na capital da República e atuação em todo o território nacional, sendo indeterminado seu prazo de duração. É integrante do Sistema Financeiro Nacional e auxiliar da política de crédito do Governo Federal, sujeita-se às decisões e à disciplina normativa do órgão competente e à fiscalização do Banco Central do Brasil.

Os funcionários do banco são admitidos obrigatoriamente mediante concurso público, de provas ou de provas e títulos sob regime jurídico da CLT (Consolidação das Leis do Trabalho) e legislação complementar. Atualmente o quadro geral é de aproximadamente 55.000 empregados em todo o território nacional.

Para atingir seus objetivos a empresa está dividida em três grandes subsistemas: central, logistico e negocial.

O subsistema central é formado pelas áreas da Matriz localizadas na sua maioria em Brasília, são elas que elaboram regulamentos e normas administrativas, além de serem os gestores de alguns processos disponibilizados no sistema logístico, para o apoio ao sistema negocial.

O subsistema logístico tem por objetivo dar suporte e apoio ao subsistema negocial.

O subsistema negocial é composto pelos Escritórios de Negócios e agências localizadas nas diversas cidades do Brasil. Cada Escritório tem sob sua responsabilidade uma série de agências próximas da sua localização geográfica e são determinadas pela área 
de gestão correspondente no subsistema central. O Escritório coordena as ações administrativas no seu âmbito de atuação.

Seguindo as tendências do mercado financeiro e de captação de recursos, também adotou o modelo de segmentação de clientela com ênfase no relacionamento (incremento produto/cliente), produtos específicos por segmento e custos (canais alternativos).

Dessa maneira os clientes, pessoas físicas, atendidos trazem diferentes resultados para a empresa, o objetivo na segmentação dessa clientela é conceder diferentes níveis de relacionamento, de acordo com o poder de compra dessa clientela, de forma que as necessidade bancárias sejam perfeitamente atendidas. Para tanto foram realizados estudos que abordaram três aspectos: diferenças compartimentais, acionabilidade e rentabilidade para o banco. A pesquisa foi feita em nível nacional englobando retrato do banco e da concorrência, abrangendo as classes A,B,C e D. Além destes existe o segmento Pessoa Jurídica que atende especialmente micro e pequenas empresas, o segmento estados e municípios.

Para conseguir implementar a segmentação da maneira como foi planejada foram antecipadas algumas ações e modificada a estrutura hierárquica na empresa, mais especificamente nas Agências.

Uma das primeiras ações foi a de aculturação do cliente para que ele utilize os canais alternativos ao invés de comparecer na Agência para pagamentos ou recebimentos diversos. Assim, a princípio os próprios empregados da empresa procuraram fazer este trabalho de educação para o uso do caixa eletrônico, home banking, deixar documentos para pagamentos nas urnas existentes na agência, etc. Atualmente esse trabalho é feito por bancários temporários, como o próprio nome diz são terceiros contratados provisoriamente.

Além disso, foi terceirizada também boa parte do serviço que antes era feito pelo caixa, como pagamentos de contas. Foi incentivada também a utilização das casas lotéricas para este tipo de serviço. 
Assim em curto prazo mudaram todas as características da empresa e conseqüentemente das agências, visando ao negócio e ao atingimento de metas de vendas. Por isso todas as forças estão concentradas nas metas e é para isso que todos os empregados da empresa devem trabalhar. Elas são apresentadas pela Vice - Presidência e seus assessores diretos aos escritórios de negócios que as repassam aos gerentes gerais. Cada gerente geral tem autonomia para repassar estas metas à sua equipe de maneira que lhe for mais conveniente. Mas a cobrança do atingimento das metas é feita à agência. Caso a agência não consiga alcançar as metas estabelecidas, o gerente geral pode perder seu cargo. Cabe ressaltar que, na época da realização deste estudo, o banco já atuava sob esta forma de organização do trabalho.

\subsection{As LER - Lesões por Esforços Repetitivos}

Quanto às LER no banco estudado foi considerado importante apresentar as caracteríticas gerais da população atendida no PRT, que possuem diagnóstico de LER, pois representam um quadro geral do adoecimento entre os trabalhadores do banco. (SESMT em São Paulo).

Os gráficos com estes dados encontram-se no Anexo II deste trabalho. Quanto ao sexo, a grande maioria eram mulheres, das 210 pessoas portadoras de LER atendidas no Programa, 172 eram mulheres $(82 \%)$ e 38 homens (18\%). Quanto à faixa etária, a maioria tanto de homens, quanto de mulheres, a idade estava entre 41 a 50 anos $(71 \%$ mulheres e $64 \%$ homens).

Das 210 pessoas atendidas no PRT portadoras de LER, 60\% mulheres possuíam o curso superior e $35 \%$ o ensino médio; ao passo que para os homens $39 \%$ possuíam o ensino superior e $47 \%$ o ensino médio. Nenhum dos homens possui pós graduação, em contrapartida existem duas mulheres com mestrado. 
Outro dado apontado foi a função que as pessoas exerciam antes e depois do afastamento. No banco estudado, entendia-se por função um conjunto de atividades com finalidade organizacional específica, não atentida pelo cargo efetivo, em face da natureza distinta e o nível superior de responsabilidade e complexidade, com ocupação em caráter transitório. A função era vinculada a um plano de carreiras anterior a 1998 e estava em extinção, ocuparia o seu lugar o cargo em comissão, que de maneira geral tinha o mesmo sentido da função, somente mudando a nomenclatura.

De maneira geral pode se descrever as diversas categorias de funções da seguinte maneira:

Anteriormente ao afastamento a grande maioria tanto das mulheres (60\%), quanto dos homens $(71 \%)$ eram caixas. Para os homens a outra categoria importante em quantidade foi de escriturários sem função (13\%) e para as mulheres foi de supervisor (8\%). Para a função em que as pessoas voltaram ao trabalho ou em que se aposentaram, a quantidade ficou assim distribuída: entre as mulheres $39 \%$ está hoje como escriturário sem função; $16 \%$ gerentes eventuais; $12 \%$ aposentaram-se por invalidez; $11 \%$ saíram do banco no Programa de Incentivo à Demissão Voluntária; e outras categorias com menor número como supervisor, analista, advogada, tesoureiro, secretária. Já entre os homens ficou assim: a grande maioria (55\%) são escriturários sem função; as outras funções têm quantidades bem menores, como gerentes eventuais, supervisor, analista e técnico, somente 3 homens $(8 \%)$ aposentaram-se por invalidez.

Para melhor entender as funções mencionadas, abaixo estão descritas as duas principais ou seja, a que trouxe maior adoecimento (caixa) e a atividade em que houve maior reabilitação profissional (escriturário sem função).

No caixa, as atividade são: atender aos clientes e público em geral; realizar rotinas de pagamento e recebimento; receber e conferir documentos, assinaturas e impressões digitais; efetuar e conferir cálculos diversos; movimentar e controlar numerários, títulos e valores; zelar pela guarda de valores, cartões, talonários de cheques e outros documentos 
sob sua responsabilidade. É obrigatória a formação em curso específico, de iniciativa do banco e percebe valor específico a título de gratificação

O outro cargo "escriturário sem função" tem esta denominação porque o empregado em questão irá desenvolver suas atividades sem ter a responsabilidade do escriturário com função. A atividade de escriturário é destinada a prestar informações a clientes e tem como atribuições principais: efetuar serviços de arquivo, protocolo, conferência de documentos e quaisquer outros ligados às atividades administrativas; preencher mapas, gráficos, tabelas e demais demonstrativos; efetuar cálculos relativos às operações, programas e serviços do banco; redigir ofícios, informações, memorandos e demais expedientes em geral; efetuar pesquisa cadastral; atender público de maneira geral, prestando informações; preparar movimentos e comandar atualização de operações, programas e serviços implantados eletronicamente; participar da execução de trabalhos gerais da Unidade, propondo solução de caráter administrativo; examinar correspondências reunindo informações necessárias para redigir e enviar respostas; realizar contatos externos com clientes, visando à divulgação de produtos e serviços; relatar e acompanhar processos administrativos e operacionais; realizar estudos e executar tarefas preliminares ou complementares na sua área de atuação; instruir processos de concessão de empréstimos e financiamentos com base em exame de dados cadastrais e atos normativos específicos; coletar dados diversos para subsidiar informações; coordenar, eventualmente, trabalhos cuja eficaz execução envolva conhecimentos adquiridos mediante experiência de atuação, vivência na empresa, bem como comprometimento efetivo com os resultados a serem alcançados; executar outras atribuições correlatas.

De modo geral, os trabalhadores, pelo menos no início do retorno ao trabalho, exerciam atividades muito relacionadas com o atendimento, orientação e encaminhamento de clientes para os diversos serviços do banco. Algumas vezes trabalhavam em postos fixos, especialmente no atendimento geral, em que o cliente deveria adquirir uma senha para o atendimento, esperando sentado por ele e, desta forma era possível ao empregado pequenas e micro pausas durante a jornada de trabalho. $O$ empregado fazia consulta a terminais de computador, mas não executava a entrada de dados. 
Em alguns outros casos os trabalhadores não possuíam um posto fixo, alternando posturas em pé e sentado, também em atendimento e encaminhamento de clientes, orientação ao uso de terminais e atendimento telefônico. Existiam também outras pessoas que eram encarregadas da cobrança de clientes em atraso com pagamentos diversos e outras pessoas também atuavam como apoio administrativo, fazendo serviços de controle de materiais, arquivo, controle do material permanente, etc.

É importante destacar que, em todos os casos, os empregados foram considerados na divisão de metas de vendas de produtos, assim a atividade de venda fazia parte das tarefas rotineiras, como de todos os outros empregados que não estavam passando pelo processo de reabilitação profissional. 


\section{OBJETIVOS}

\subsection{Objetivo Geral}

Analisar o processo de reabilitação profissional de bancários com diagnóstico de LER (Lesões por Esforços Repetitivos), de um banco da região metropolitana de São Paulo.

\subsection{Objetivos Específicos}

- Verificar os pontos facilitadores e dificultadores no retorno ao trabalho

- Identificar, em especial, os aspectos psicossociais associados à reabilitação profissional. 


\section{PROCEDIMENTOS METODOLÓGICOS}

\subsection{Metodologia utilizada}

Para Oliveira (1998) método significa um rumo escolhido entre tantos possíveis. Mas esta escolha deve ter critérios: “ (..) o método não representa tão somente um caminho qualquer entre outros, mas um caminho seguro, uma via de acesso que permita interpretar com maior coerência e correção possíveis as questões sociais propostas num dado estudo, dentro da perspectiva abraçada pelo pesquisador." (pg.17)

Se o método é uma escolha entre várias possíveis, é importante ter critérios relacionados com a pesquisa e com o pesquisador, que deverá buscar esta consonância. Oliveira (1998) expressou essa necessidade, pois atribuiu vida ao estudo, além de ser bastante estimulante. Mas advertiu que o pesquisador deve manter uma relação ambígua com a experiência, procurando não reproduzir simplesmente a realidade que estuda e na qual está inserido.

A autora deste estudo tem na sua prática cotidiana a experiência com a reabilitação profissional, acompanhando trabalhadores que necessitam retomar suas atividades laborativas. Desta forma a autora analisou esta prática, de modo a poder contribuir para a sua melhoria, procurando atender aos preceitos apresentados por Oliveira (1998) de distanciamento necessário para a compreensão de uma realidade. Assim, houve momentos em que a autora assumiu a posição de pesquisadora, fazendo registros e elaborando novos instrumentos para aprofundamento da análise.

Tendo em vista estas considerações, neste estudo optou-se pela utilização da metodologia qualitativa. Segundo Minayo (1994) “(...) as Metodologias de Pesquisa Qualitativas são entendidas como aquelas capazes de incorporar a questão do significado e da intencionalidade como inerentes aos atos, às relações e às estruturas sociais, sendo estas 
últimas tomadas tanto no seu advento quanto na sua transformação, como construções humanas significativas." (pg.10)

Além disso pode-se dizer que , apesar do processo saúde - doença ser vivenciado indistintamente, as condições de vida e trabalho interferem diretamente, não só no corpo físico, com também no mental e no social, podendo promover a saúde ou a doença. Minayo (1994) apresentou essa discussão da seguinte maneira: "Saúde e doença são fenômenos clínicos e sociológicos vividos culturalmente, porque as formas como a sociedade os experimenta, cristalizam e simbolizam as maneiras pelas quais ela enfrenta seu medo da morte e exorciza seus fantasmas. Neste sentido saúde/doença importam tanto por seus efeitos no corpo como pelas suas repercussões no imaginário: ambos são reais em suas conseqüências.” (p. 15)

Ainda segundo Minayo (1994), representações sociais são definidas dentro das ciências sociais como ".... categorias de pensamento, de ação e de sentimento que expressam a realidade, explicam-na, justificando-a ou questionando-a . " (pg. 158)

Jodelet (1985) citado em Spink (1995) expressou o conceito de representações sociais como "... modalidades de conhecimento prático orientadas para a comunicação e para a compreensão do contexto social, material e ideativo em que vivemos. (...) Deste modo, as representações são essencialmente fenômenos sociais que, mesmo acessados a partir do seu conteúdo cognitivo, têm de ser entendidos a partir do seu contexto de produção." (pg. 300)

Luckás (1974) utilizou o termo "visão de mundo", o qual contempla as idéias e aspirações de grupos de pessoas, ou seja, partindo das consciências individuais, a consciência coletiva é despertada e precisa ser descoberta.

Como exprimiu Minayo (1994): "....por serem ao mesmo tempo ilusórias, contraditórias e "verdadeiras", as representações sociais podem ser consideradas matéria - 
prima para a análise do social e também para a ação pedagógica política de transformação, pois retratam a realidade." (p. 174)

O estudo das representações sociais sob a perspectiva do processo saúde/doença acaba revelando as concepções existentes na sociedade como um todo. Isto porque cada sociedade tem a sua interpretação a respeito da saúde, da doença, da vida e da morte. Como expressou Minayo (1994) “ (...) a partir das ciências sociais podemos dizer que há uma ordem de significações culturais mais abrangentes que informa o olhar lançado sobre o corpo que adoece e que morre. A linguagem da doença não é, em primeiro lugar, linguagem em relação ao corpo, mas à sociedade e às relações sociais." (p. 177)

Neste estudo buscou-se conhecer as representações sociais sobre o processo de reabilitação profissional dos bancários portadores de LER e, dentre todas as possibilidades de instrumental existentes no quadro da metodologia qualitativa, a opção foi pelo Discurso do Sujeito Coletivo - DSC.

Segundo Lefrève (1999) o Discurso do Sujeito Coletivo, enquanto instrumental, propõe a organização de dados discursivos, como uma maneira de ter acesso aos dados de realidade que se apresentam subjetivamente. Esta proposta implica utilização de quatro "figuras metodológicas" quais sejam: ancoragem, idéia central, expressões - chave e o discurso do sujeito coletivo.

A ancoragem tem sua base em hipóteses, pressupostos, usos e costumes da sociedade, mas os autores destacam que as ancoragens são "marcas lingüísticas encontradas nos discursos; explicada de uma outra maneira, dentro da Teoria das Representações Sociais, na ancoragem podem ser encontrados "traços lingüísticos" que tornam claras as hipóteses, conceitos e ideologias que circulam na sociedade. Os autores apresentam como ponto forte da ancoragem, a possibilidade de sua utilização para ações educativas. 
Quanto à idéia central, está assim definida “(...) poderia ser entendida como a (s) afirmação(ões) que permite(m) traduzir o essencial do conteúdo discursivo explicitado pelos sujeitos em seus depoimentos." (Lefèvre , 1999, pg.18)

As expressões - chave se constituem na matéria - prima para a construção do Discurso do Sujeito coletivo. Os autores as definiram como “(...) transcrições literais de partes dos depoimentos, que permitem o resgate do essencial do conteúdo discursivo dos segmentos em que se divide o depoimento(...)" (Lefèvre ,1999, pg.18).

O Discurso do Sujeito Coletivo aparece sob a forma de um único discurso, e representa a idéia de uma coletividade a respeito de um determinado tema. Pelo acima exposto, os discursos dos vários sujeitos são analisados e tratados de maneira a explicitar a idéia do todo, apresentada como se fosse a idéia de um só sujeito. Os autores destacam que o Discurso do Sujeito Coletivo é uma "expressão simbólica" das idéias que circulam em uma coletividade em um dado momento histórico, e que por isso não é uma "soma aritmética", mas uma agregação discursiva que não reúne iguais, mas pedaços de diferentes discursos individuais que, pelo que se julga ser sua intercompatibilidade, permitem, como se fossem ingredientes agregáveis, compor um único "bolo discursivo".

No presente caso optou-se por este tipo de estudo, porque o discurso possui uma qualidade importante que é a de explicitar em uma única via tanto a realidade exterior, quanto o universo mental do indivíduo.

\subsection{Procedimentos adotados}

O presente estudo foi realizado entre os empregados de um banco federal, no âmbito do SESMT (Serviço Especializado de Engenharia de Segurança e Medicina do Trabalho) São Paulo, que abrange a Grande São Paulo, Baixada Santista e Região do Vale do Paraíba, sendo no total aproximadamente 7.000 empregados. 
Para a realização deste estudo, partiu-se da experiência de atendimento dos empregados no Programa de Readaptação ao Trabalho - PRT, programa de reabilitação profissional do banco estudado, que acompanha os casos de afastamento do trabalho ou não, mas que apresentem dificuldades laborativas. Foram atendidos 539 empregados entre 1999 a 2002, conforme mostra a tabela do anexo I. Destes 539 empregados, 210 estão afastados com diagnóstico de LER (Lesões por Esforços Repetitivos), 158 por vários motivos de saúde e 171 por doenças psiquiátricas.(Anexo I)

Além deste atendimento, o PRT se utiliza de uma atividade denominada Grupo de Atenção, que corresponde a um atendimento grupal de pessoas portadoras de patologias semelhantes, com o objetivo de discutir os problemas enfrentados por eles, bem como a facilitação dos encaminhamentos necessários à recuperação da saúde. A inclusão de participantes é feita por adesão, mediante preenchimento de formulário próprio, onde constavam as diretrizes do grupo. Esta ação é prevista pelo PRT, quando há um número adequado de participantes.

Este grupo é coordenado por profissional da área de saúde da empresa. As reuniões deste grupo acontecem em local disponibilizado pela área de recursos humanos, com duração de até duas horas, uma vez por semana, num total de 12 semanas, conforme necessidades identificadas e sob acompanhamento da equipe do PRT.

Cada grupo deve ser composto por um mínimo de 6 e no máximo 16 empregados, podendo ser criados grupos semelhantes fora da região metropolitana, quando a quantidade de empregados assim o justifique.

Para o presente estudo, houve o desenvolvimento de um grupo específico que foi coordenado pela autora e uma psicóloga da empresa, contando com a participação de 8 pessoas ( 7 mulheres e um homem) que estavam afastados do trabalho por auxílio doença acidentário, com diagnóstico de LER e nexo causal dado pelo perito do INSS. Todos foram encaminhados ao PRT pela reabilitação profissional do INSS, para processo de retorno ao trabalho. É importante destacar que, para esta ação a autora assumiu a posição de 
pesquisadora, fazendo registros e prestando atenção em aspectos específicos definidos pelos objetivos deste estudo.

Cada um destes empregados estava sendo acompanhado pelo PRT e, antes da participação no Grupo de Atenção, já haviam passado por avaliação do médico e da psicóloga do Programa, para complementação diagnóstica, orientação de tratamento e estabelecimento das restrições laborativas. Pela análise desses profissionais, todos os empregados reuniam condições físicas de retorno ao trabalho, com alguns encaminhamentos para terapia ocupacional, diferenciando-se somente nas questões psicológicas, algumas pessoas precisaram de intervenção terapêutica como auxiliar no retorno ao trabalho.

Para cada um destes empregados foi feita uma Proposta de Requalificação Profissional, que é um documento elaborado em conjunto com o gerente da Unidade que recebe o empregado, onde constam restrições laborativas, novas tarefas a serem desenvolvidas, necessidade de treinamento e fatores de avaliação do desempenho das atividades.

Como uma das etapas do processo de reabilitação tanto do INSS, quanto do PRT, esses empregados realizam um estágio de 30 dias estando ainda em auxílio doença acidentário, autorizado pelo INSS através da homologação da Proposta de Requalificação Profissional, acima mencionada. Assim, quando estes empregados participaram do Grupo de Atenção, já existia um local e tarefas definidas para o retorno ao trabalho.

No caso deste Grupo específico, no qual a autora participou da coordenação, foram feitas quatro sessões anteriores ao estágio, mais duas sessões, sendo uma após a finalização do estágio e a outra após a alta do INSS, quando do retorno definitivo ao trabalho.

Nas quatro sessões anteriores ao estágio, procurou-se refletir e discutir sobre diferentes assuntos, mas especialmente sobre as expectativas dos participantes quanto ao retorno ao trabalho. No Grupo de Atenção foram aplicadas técnicas de condução e 
facilitação de grupo como dinâmicas, elaboração de cartazes, sociodrama e discussões. Estas técnicas foram elaboradas sempre a partir do conteúdo trazido pelo grupo de pessoas durante as discussões, num processo dinâmico.

No caso específico deste Grupo, em virtude dos depoimentos freqüentes de receio com relação à recepção que eles teriam no retorno ao trabalho, foi elaborado um questionário e distribuído entre colegas e chefias destas pessoas que estavam participando do Grupo de Atenção. O questionário foi enviado para oito unidades diferentes num total de 50 empregados; destes voltaram 27 questionários respondidos, sendo que todas as unidades, com maior ou menor número de respostas, estão representadas nestes questionários.

Após a realização deste Grupo, a autora percebeu que era necessário um aprofundamento da análise e o instrumento escolhido foi a entrevista. Desta forma, valendo-se do conhecimento adquirido no atendimento do PRT e no desenvolvimento do Grupo de Atenção, partiu-se para a elaboração do roteiro de entrevista e da seleção dos empregados que seriam entrevistados.

Segundo Lefrève (2001), devem ser tomados alguns cuidados na elaboração das perguntas, tais como, não fazer perguntas com respostas induzidas; que ensejam discursos; inadequadas para a população alvo ou incompreensíveis. Assim, as perguntas devem ser feitas com uma linguagem coloquial, deixando claro o seu objetivo.

Portanto, levando-se em consideração todos estes fatores foi elaborado a princípio um roteiro semi - estruturado, onde a questão serviu de fator motivador para o entrevistado fornecer os dados necessários para a análise, sem forçar respostas, servindo como estímulo para a interação entre o pesquisador e o informante. As questões iniciais foram:

1- Depois do seu afastamento por causa da LER você voltou a trabalhar no banco, não é? Conta como foi isso para você.

2- Alguma coisa em especial atrapalhou na sua reabilitação profissional? Fale um pouco sobre isso. 
3- Agora o contrário, o que ajudou na sua reabilitação? Teve alguma coisa em especial que ajudou? Fale um pouco sobre isso.

Outras questões foram sendo incorporadas à entrevista, variando com o discurso, no sentido de procurar compreender melhor a situação e as representações sobre determinado assunto. Por exemplo, um dos entrevistados estava comentando que as pessoas portadoras de LER não aparentavam fisicamente a doença, e, foi perguntado se este fato o incomodava, pois era importante o conhecimento da representação da invisibilidade da dor naquele momento. E assim, outras questões foram feitas de acordo com o discurso apresentado.

Quanto à seleção dos sujeitos a serem entrevistados levou-se em conta que a questão da amostra na pesquisa qualitativa e, especialmente utilizando-se um instrumental como o Discurso do Sujeito Coletivo, estaria mais relacionada com a qualidade, do que com a quantidade. Por isso a variabilidade dos sujeitos foi muito mais importante do que o número de pessoas, pois neste caso, foi preciso atentar para as possibilidades de idéias presentes em um dado campo social. A escolha foi baseada na experiência profissional da autora que, por trabalhar na área de saúde ocupacional do banco estudado, pôde selecionar sujeitos em diferentes condições anteriores e posteriores ao retorno, fazendo com que a amostra apresentasse a diversidade necessária para a obtenção dos dados. A escolha destas pessoas, foi baseada nas experiências boas ou más de retorno ao trabalho.

Assim, para a realização da pesquisa foram entrevistados 16 bancários com diagnóstico de LER (nexo causal estabelecido pelo INSS), que estavam sendo acompanhados pelo PRT. (Anexo II) Além disso, para garantir a qualidade das respostas foram observadas entre os escolhidos algumas características: grau de instrução que permitisse o entendimento dos objetivos da pesquisa; capacidade de expressão adequada; capacidade de compreensão realística da situação que estava sendo vivenciada e analisada; experiência profissional e o fato de terem passado por todo o processo de reabilitação. 
Os empregados foram contatados por telefone, ou então durante as entrevistas no PRT. É importante destacar que não houve recusas para a realização das entrevistas, os participantes foram comunicados de que se tratava de uma pesquisa e aceitaram colaborar, assinando o termo de consentimento (Anexo IV) antes da entrevista. Ficou esclarecido que não haveria danos materiais ou morais e que seus nomes não seriam revelados em hipótese alguma. Foi agendada uma data e o local foi o mesmo do atendimento do PRT. As entrevistas tiveram em média a duração de 45 minutos e foram realizadas individualmente.

As entrevistas foram gravadas e transcritas literalmente. Cada entrevista foi denominada com a letra $\mathrm{E}$ seguida do número correspondente à ordem cronológica de sua realização, por exemplo: E.1; E.2 e assim por diante. Estas entrevistas foram lidas diversas vezes com o intuito de familiarização do seu conteúdo global. Este procedimento possibilitou a identificação de temas e subtemas dentro de cada uma das questões do roteiro elaborado, o que permitiu uma melhor análise do contexto apresentado pelos entrevistados.

O passo seguinte foi a construção do Instrumento de Análise do Discurso I (IAD I Anexo III) composto das Expressões Chave, agrupadas por semelhanças ou equivalências dentro de cada um dos temas e subtemas. Logo após, nesse mesmo Instrumento foram destacadas as Idéias Centrais e a partir desse conjunto, houve a possibilidade de construção do Discurso do Sujeito Coletivo. É importante destacar que para a construção do Discurso do Sujeito Coletivo os depoimentos foram transcritos para o feminino, visando facilitar ao leitor o seu entendimento.

A elaboração dos temas e subtemas para a localização das expressões chave e idéias centrais partiu da experiência adquirida no cotidiano profissional, no desenvolvimento do grupo de atenção, na realização das entrevistas e nos objetivos do estudo. 


\subsection{Descrição dos Sujeitos que participaram das entrevistas}

Os dados a seguir se referem à população selecionada para as entrevistas, e encontram-se no Anexo II. Quanto ao sexo são 14 mulheres e 2 homens.

Quanto à faixa etária os sujeitos das entrevistas ficaram assim divididos: $22 \%$ das mulheres entre 31 a 40 anos e nenhum homem; na faixa etária entre 41 a 50 anos estão $78 \%$ das mulheres e $100 \%$ dos homens; e somente uma mulher (7\%) na faixa etária dos 46 a 50 anos. Em relação ao grau de instrução: $71 \%$ das mulheres e $50 \%$ dos homens têm curso superior; $29 \%$ das mulheres e $50 \%$ dos homens com ensino médio.

Com relação à função exercida anteriormente ao afastamento a divisão: $71 \%$ das mulheres e $100 \%$ dos homens eram caixas; $21 \%$ das mulheres eram supervisoras e uma mulher (8\%) era auxiliar de supervisão. No banco estudado o caixa é o posto de trabalho onde se localiza o maior número de casos de LER. Neste posto não existe muita digitação, porém existe todo o controle de numerário e documentação, além da exigência de vendas de produtos, presteza, atenção, concentração. É um posto visado por estelionatários e assaltantes, sendo este considerado um risco importante para a saúde mental. $O$ outro posto de trabalho que trouxe o adoecimento para os sujeitos da pesquisa foi o de supervisor que não utiliza a digitação, porém tem a responsabilidade por todo o andamento do serviço de caixas, bem como da venda de produtos para o atingimento de metas.

A situação atual de trabalho dos sujeitos selecionados para as entrevistas encontrase da seguinte maneira: os dois homens estão trabalhando como escriturários sem exercer nenhuma função (o conceito de função já foi anteriormente descrito no item LER no banco estudado), suas tarefas são de atendimento ao público em geral (informações, vendas de produto, FGTS) existe consulta a sistemas no computador, além de atendimento telefônico. As 9 mulheres estão trabalhando nas mais diversas tarefas, são analistas na área de habitação; executam atividades de secretaria, atendimento ao público em geral na agência, com substituição de gerência; técnica na área de saúde; supervisão de pessoas na área da retaguarda de agência. 
Entre as mulheres duas continuam em auxílio doença acidentário, não tendo conseguido terminar seu processo de reabilitação profissional. Uma das mulheres estava trabalhando, porém não conseguiu permanecer no trabalho e atualmente está afastada por LER, com nexo dado pelo INSS. Uma outra mulher encontra-se afastada por licença maternidade e tem pretensões de tirar uma licença sem vencimentos. A última mulher está aposentada por invalidez. 


\section{RESULTADOS}

Os resultados estão aqui apresentados divididos pelos três procedimentos diferentes: quanto ao programa de reabilitação no banco estudado; quanto ao trabalho desenvolvido com o Grupo de Atenção; quanto às entrevistas realizadas utilizando-se o Discurso do Sujeito Coletivo.

\subsection{Quanto ao Programa de Reabilitação Profissional}

Os bancários costumam procurar a área responsável (SESMT) com um Laudo de Exame Clínico Ocupacional - LECO - que é um documento instituído internamente para subsidiar melhor o preenchimento da CAT, e contém as seguintes informações: em primeiro lugar o médico assistente descreve a doença existente, bem como o tratamento indicado e o prognóstico; logo após o bancário descreve as atividades que desenvolve no trabalho até o momento do diagnóstico; a gerência apresenta a parte administrativa, dizendo se as tarefas são constantes e como são solicitadas; e por último o médico do trabalho do SESMT coloca sua análise da situação.

Após 15 (quinze) dias de afastamento, este documento (LECO) é encaminhado ao INSS, juntamente com a CAT preenchida e devidamente assinada. É feita então uma avaliação pela perícia médica do INSS que pode dar ou não o nexo causal. Se for dado nexo causal e o afastamento do trabalho, o bancário ficará em licença por Auxílio Doença Acidentário no tempo determinado pela perícia médica do INSS e fará avaliações periódicas, sempre que vencer seu período de licença (DCI - Data da Cessação da Incapacidade).

É prerrogativa da perícia médica do INSS definir a situação de afastamento deste bancário com LER, ou qualquer outra doença, que pode variar entre: dar continuidade ao afastamento; conceder aposentadoria por invalidez ou encaminhar para a reabilitação profissional, com vistas ao estabelecimento de restrições físicas considerando as seqüelas 
existentes, bem como o retorno ao trabalho em tarefas compatíveis com tais restrições. Neste estudo analisamos o que ocorre na reabilitação profissional.

Existe uma tendência da seguridade social em passar a responsabilidade pela reabilitação profissional para as empresas. Foi firmado um convênio de cooperação técnica entre o INSS e o banco estudado no sentido de encarregar o banco da reabilitação, ficando a critério do INSS a decisão pela homologação das ações previstas.

A primeira cláusula do convênio tem a seguinte redação: "O presente Convênio, com base na RS/INSS/PR $n^{\circ} 439$ de 10/04/97 tem por objetivo a readaptação profissional dos empregados do banco, com troca ou não de função/posto de trabalho que, após exame médico pericial, estejam em percepção de auxílio doença e sejam portadores de patologias incapacitantes para a função que exercem, mas que reunam condições para o desempenho de outra."

Desta maneira, aqueles empregados em percepção de auxílio doença que forem encaminhados pela perícia médica do INSS à Reabilitação Profissional, são acompanhados pelo Programa de Readaptação ao Trabalho - PRT. Este Programa passou a ser formalmente uma ação institucional com gestão localizada na Matriz e dotação orçamentária específica. Ele tem como finalidade última oferecer suporte técnico e administrativo ao gerente em seus esforços para o restabelecimento das condições laborativas dos empregados, bem como fornecer acompanhamento especializado e apoio aos participantes. O PRT tem uma coordenação regional e é composto por profissionais de saúde do quadro da empresa, e por contratados. As entrevistas com os empregados são realizadas por um médico do trabalho ou psiquiatra e um psicólogo e acompanhadas por profissional de saúde (psicólogo ou assistente social) do quadro da empresa, tendo a duração média de 60 minutos cada uma, com periodicidade variável de acordo com cada caso, podendo ser entre 30 a 180 dias.

O público alvo do Programa são os empregados afastados por LAT - Licença por Acidente de Trabalho e LTS - Licença Tratamento de Saúde, ou ainda empregados que 
necessitem de troca de função/posto de trabalho, como forma de prevenção de riscos relacionados ao trabalho e empregados que apresentem dificuldades de integração à equipe e/ou atividades laborativas.

O Programa é composto por três fases:

A primeira é a fase de triagem que objetiva definir se o empregado, cuja inscrição foi solicitada atende às condições básicas para participar do programa, ou seja, são verificadas as informações existentes sobre o empregado nos sistemas disponibilizados e é avaliado se o gerente utilizou todos os instrumentos e medidas institucionais e informais de apoio e orientação ao seu alcance, em relação à situação apresentada. Os empregados em Licença - Acidente de Trabalho há mais de 90 dias são inscritos no Programa automaticamente, bem como aqueles que são encaminhados pela Reabilitação Profissional do INSS.

A segunda é denominada fase de atenção à saúde e tem como objetivos avaliar, encaminhar para tratamento e acompanhar os empregados no sentido da recuperação dos aspectos de sua saúde biopsicossocial. Esta fase estende-se pelo tempo necessário à recuperação dos aspectos de saúde, podendo ser realizada em conjunto com a próxima fase de potencialização laborativa, caso o empregado apresente condições parciais de trabalho ou ainda se sua saúde necessite maior atenção. Nos casos de doença crônica, esta fase tem duração indeterminada, ou mesmo nos casos em que se aguarda decisão do INSS quanto à alta ou aposentadoria.

As principais ações desenvolvidas nesta fase têm relação com o conhecimento e orientação. Assim é realizada inicialmente uma entrevista, quando é feita a coleta de informações a respeito do princípio e da evolução da situação de saúde do empregado. Nessa entrevista o empregado apresenta relatórios de cada profissional assistente (médicos, fisioterapeuta, terapeuta ocupacional, psicólogo, entre outros) onde devem constar o quadro geral, o prognóstico e plano de tratamento. Se fosse do entendimento dos profissionais do Programa eram solicitados exames complementares. Desta forma existem condições de se 
avaliar o grau de comprometimento da capacidade laborativa do empregado e a necessidade ou não de encaminhamento para tratamento.

Existem duas dificuldades observadas nesta fase, por este estudo. Uma delas esta relacionada com o fato de muitos dos profissionais - assistentes direcionarem tanto a ação diagnóstica quanto de tratamento para a área ortopédica, especialmente quando a pessoa se apresenta como bancário e suas queixas se referem a esta área. Durante o atendimento no Programa, em alguns casos, após a realização de exames clínico e alguns complementares, foi percebido o diagnóstico incorreto. Por exemplo, foi encontrado um caso de lupus sendo tratado há meses como LER. E como este, existem outros casos em que o corpo é reduzido a músculos e tendões e a dor passa a ser vista de maneira incorreta, por tratar-se de um bancário.

A outra dificuldade nesta fase, observada através deste estudo, vem da perícia do INSS que por vezes não procura compreender a situação da maneira correta, apresentando resultados que não contribuem para o restabelecimento do empregado. Assim, algumas pessoas que devem continuar afastadas recebem alta e outras em que é necessário o retorno, isso não ocorre.

A última fase é denominada potencialização laborativa e tem por objetivo recuperar a capacidade laborativa do empregado, no que se refere aos aspectos de integração às atividades, ao processo de trabalho $\mathrm{e}$ à equipe da Unidade, complementarmente às ações desenvolvidas pela gerência da sua unidade de lotação. Esta fase tem duração de 180 dias, compreendendo o período de readaptação - estágio ou treinamento - e/ou avaliação da Unidade em que o empregado deve atuar. O empregado pode participar desta fase ainda estando na fase de atenção à saúde, considerando sua capacidade laborativa preservada. No final, se o empregado for considerado inapto para o retorno ao trabalho, ele volta à fase anterior (atenção à saúde).

As principais ações nesta fase são: 
- Avaliação da situação atual, do perfil e da capacidade laborativa do empregado. Para o estabelecimento das restrições são utilizados recursos dos relatórios de todos os profissionais de saúde que acompanham o empregado, exames complementares e aqueles informados pelos peritos do INSS (Reabilitação Profissional). Se o empregado já vem sendo acompanhado pelo PRT fica mais fácil o estabelecimento da sua capacidade laborativa, caso contrário, tendo em vista o prazo exíguo, esta avaliação é feita baseada essencialmente nos dados do INSS. Este levantamento é de extrema importância, uma vez que as atividades são estabelecidas com base nestas restrições. Uma outra ação neste período é saber do empregado quais suas aptidões e aspirações com relação às tarefas que ele irá desenvolver no retorno ao trabalho.

1 Identificação da Unidade e do posto de trabalho mais adequado às condições atuais do empregado. Nesta ação são consideradas as restrições e o perfil levantado anteriormente.

Elaboração da programação de requalificação profissional. Aqui é realizada uma reunião entre o empregado que estava sendo reabilitado, o gerente da unidade que irá recebê-lo e um profissional do PRT. Nesta reunião são apresentadas as restrições e o perfil do empregado em questão, procurando identificar as tarefas mais adequadas para as atuais condições daquele empregado. Aqui também são estabelecidos fatores e indicadores sobre o desempenho profissional, não sendo permitida a avaliação quantitativa, somente a qualitativa. Este instrumento serve como guia para a análise final, decorridos os 30 dias de estágio estabelecidos pelo INSS.

1 Esta programação é encaminhada ao INSS para homologação.

- Estão previstas ações de consultoria à Unidade que estará recepcionando o empregado para a reabilitação, no que se refere à potencialização laborativa do mesmo. É solicitado ao gerente da Unidade que realize uma reunião com a equipe para explicar todo o processo de reabilitação.

- Análise dos relatórios periódicos de acompanhamento do desempenho do empregado, mesmo após a alta concedida pelo INSS.

- Registro de parecer conclusivo sobre a situação do empregado, com emissão de instrumento assinado pelo empregado, gerente e profissional do Programa. 
As principais dificuldades encontradas nesta fase, por este estudo, estão relacionadas com: profissionais assistentes que ainda continuam focados no tratamento da dor em si, e não no retorno ao trabalho; peritos do INSS e da Reabilitação Profissional que não procuram compreender a situação de cada empregado, tomando atitudes baseadas nas generalizações; as equipes das Unidades que, não entendendo o processo de reabilitação, acabam sobrecarregando o empregado que retorna, justamente na fase de recuperação.

\subsection{Quanto ao trabalho com o Grupo de Atenção}

Uma das primeiras dificuldades apresentadas foi com relação aos limites. As pessoas disseram ser complicado ver os colegas de trabalho dentro de um ritmo e quem está retornando tem que dizer "Não posso fazer! O que os colegas vão dizer?" (sic) Existe muito receio do preconceito com relação à doença, muitos deles já ouviram chefias e colegas comentando que eles estão bem fisicamente e alguns extrapolam, afirmando que trata-se de fingimento da dor. Para uma melhor reflexão sobre este assunto, foi feita uma dinâmica em que metade do grupo eram empregados de uma agência recebendo a outra metade do grupo, que fizeram o papel de portadores de LER retornando ao trabalho. Os sentimento e comentários posteriores a esta dinâmica foram: as pessoas acreditam que para o gerente é mais um problema para resolver, na correria do dia - a - dia não dá para dar mais atenção ao empregado que está retornando, além disso este é um empregado que vai trazer um custo para a unidade e ele nem pode participar de forma adequada nas vendas dos produtos. Com relação ao papel do empregado que está com LER, existe um sentimento de insegurança quanto ao nível de conhecimento e a forma com que se vai atender aos clientes ou mesmo às demandas do serviço.

Em uma outra reunião foram elaborados dois cartazes: um contendo respostas em forma de figuras sobre "Como eu acho que serei recebido na unidade", e o outro sobre "Como eu gostaria de ser recebido na unidade". As idéias centrais de como as pessoas acreditavam que seriam recebidas giravam em torno de: preconceito com relação à doença; qual o papel de cada um no retorno; resistência de ambas as partes; investimento da 
empresa em ergonomia, mas não em recursos humanos; hoje tudo está mudado no banco, a pressão para vendas é grande.

$\mathrm{Na}$ outra reunião foi trabalhada a questão do limite. Foi proposta uma atividade em que as pessoas ultrapassavam seus limites pessoais para cumprir tarefas, sem questionar para quê e sem planejar ou mesmo sem se conscientizar dos próprio limites.

No âmbito geral os sentimentos das pessoas do grupo foram: no momento eles se encontravam estáveis, tanto com relação à dor, quanto ao respeito aos limites, o medo é que o fato de não conseguir dizer não, faça com que a dor retorne e a possibilidade de sentir a mesma dor traz medo, é algo insuportável. Nesta mesma linha de raciocínio vem a insegurança de não estar apto física e intelectualmente para o retorno, algumas pessoas estavam afastadas há muito tempo e na visão delas a empresa agora é outra, com novas metas e novas regras. Elas serão colocadas à prova e, isso traz insegurança e angústia de não dar certo, voltar a adoecer, não se sentir ainda em condições de retornar, ainda sentir muita dor, o preconceito das pessoas, a quantidade e o tipo de tarefas que vão assumir, não ter conhecimento suficiente, não conseguir dizer não.

O resumo das respostas abaixo descrito diz respeito ao questionário preenchido por colegas e chefias que receberiam os participantes do Grupo de Atenção:

\section{1- O que você conhece sobre LER/DORT?}

São lesões que o trabalhador apresenta no exercício de sua profissão devido a esforços repetitivos; doença adquirida por esforços repetitivos com inflamação dos tendões; são problemas causados pelo excesso de tarefas efetuadas/executadas sem o devido cuidado de exercitar os músculos com descansos intercalados; lesão causada por movimentos repetitivos e contínuos que causam dor, inchaço e se não tratada a tempo pode causar invalidez; lesões que uma pessoa pode adquirir quando no ambiente de trabalho se submete a esforços repetitivos ou ainda exerce atividades de forma incorreta, a qual pode abalar sua saúde, lembrando sempre que isso varia de acordo com o organismo de cada pessoa; doença profissional referente a movimentos repetitivos; são lesões causadas por 
movimentos contínuos e repetitivos no ambiente de trabalho, por exemplo a tendinite causada por digitação; é um mal que aflige milhares de pessoas hoje em dia e é ocasionado pelos hábitos de vida e trabalho modernos, onde as pessoas se submetem a movimentos contínuos e repetitivos que acabam por provocar lesões musculares; tem a ver com a informática, chamado "mal do século"; tem incidência grande na empresa. Já tive colegas que voltaram ao trabalho; já tive o diagnóstico, tem que cuidar da postura, fazer exercícios de alongamento; tenho uma cunhada com LER em outro banco, minha esposa tem e trabalha na empresa, tem muita dor; eu conheço o que é pela doença do outro; é devido a movimento repetitivo e má postura, inflamação do tendão, não consegue mais fazer movimentos; doença por esforço repetitivo, má postura e digitação; dores que se manifestam através de movimentos repetitivos; LER é diferente de DORT, todos os que têm DORT têm LER; inflamação dos tendões devido a esforço repetitivo que causa dor insuportável; relacionada ao trabalho, tem algumas que não estão, depende da atividade, se é repetitivo, tem que ter pausas; eu tenho inflamação no músculo decorrente de esforço repetitivo.

2- Você sabe que um colega irá realizar um estágio de reabilitação na sua unidade? Vinte e três disseram ter conhecimento e 4 não sabiam.

\section{3- Você sabe o que isso significa?}

Que a pessoa irá passar por um período de adaptação, onde tentará ser produtivo de acordo com suas condições físicas; sei; tentará exercer suas atividades sem prejudicar sua recuperação; reintegrar o empregado ao trabalho procurando utilizá-lo em áreas que não o prejudiquem; retornará ao trabalho com algumas restrições; ele estará sob observação para ver se há possibilidade para o retorno definitivo; um processo de reabilitação; readaptação /retorno ao trabalho/atividade que possam ser exercitadas de forma limitada com restrições; voltará ao ambiente da agência buscando exercer funções as quais não venham colocar sua saúde em risco; terá algumas limitações nas execuções das tarefas; a pessoa passará um estágio de readaptação ao trabalho em atividades que não provoquem movimentos repetitivos que possam ocasionar lesões no local antes afetado, agravando ainda mais a situação; é um estágio de reabilitação ao serviço, que não pode ser o mesmo que o lesionou 
nem que provoque reinflamação; um teste para ver se a pessoa se adapta à realidade, se não vai sentir dor, se adapta à tarefa, nós vamos analisar e ela vai analisar também, vai estar mais ouvindo o que tem a dizer se está adequada a trabalhar na agência, atender público; a pessoa vai estar se adaptando ao ambiente de trabalho, ambientar os clientes ao convívio, parte psicológica deve estar integrada à equipe; voltar ao trabalho aos poucos; nova adaptação da realidade da pessoa ao trabalho; adaptação ao serviço.

\section{4- Você sabe o que significa um colega apresentar restrições?}

Que não poderá fazer tudo o que fazia antes da mesma maneira; sim; estará proibida de realizar certas tarefas; sim, executar serviços que não venham a agravar o seu problema; existem atividades que ele não pode exercer devido a sua doença; ele não deverá ser submetido ao exercício de determinadas atividades; muitas atividades que eram exercidas pelo mesmo serem substituídas por outras que exerçam sem que causem ou agravem mais seus problemas de articulação; é uma situação constrangedora pois a meu ver, ninguém gosta de se sentir como incapaz de realizar qualquer atividade que seja, tanto na vida particular, quanto na profissional; dependendo do caso, não poderá exercer algumas atividades visto que essas foram identificadas como sendo atividades que possam abalar sua saúde; não é fácil a pessoa querer efetuar suas tarefas e não poder; um colega que não possui condições físicas e/ou emocionais adequadas para a realização de determinados trabalhos; é a pessoa que apresenta condições fisiológicas ou psicológicas que o impedem de exercer determinadas atividades; ter dificuldade, ter medo; limitações para algumas atividades que não pode acompanhar; não pode digitar o dia inteiro, não carregar peso, ter paradas, dar trabalho que não piore a lesão; pode estar relacionado com digitação, no caso não pode forçar a musculatura; não tem condições de fazer um bom trabalho, não está disponivel para fazer qualquer tipo de trabalho, está afastada por isso ou volta a trabalhar ou se aposenta, a gente conhece pessoas que estão afastadas e trabalham em outros empregos; limitada; não vai poder fazer uma série de coisas; não; adaptação ao serviço; a pessoa fica meio deprimida e se considerando inválida, este programa é para conhecer o trabalho e entender que não é incapaz, se readaptar; eu sei por outras pessoas, a LER é malvista pois tem gente que abusa e tem gente que está doente mesmo, é sempre uma situação de constrangimento para o empregado. 
5- O que você acha que uma pessoa com restrições pode fazer?

Desenvolver outras formas de trabalhar, ou seja, produzir de acordo com as metas da empresa, sem sobrecarregar o físico; pode atender os clientes, evitando digitação de documentos, muitas ligações telefônicas e outros trabalhos que possam comprometer os tendões; ajudar em tarefas que não prejudiquem a sua recuperação; existem vários serviços que alguém que tem LER possa fazer na empresa como: atendimento geral, prestando informações, cobrança de clientes por telefone, telemarketing; telemarketing, cobrança, informações; pode trabalhar em triagem; depende das restrições médicas; atendimento ao público e orientação ao cliente; atendimento ao público, telefone; pode fazer tudo aquilo que, segundo o diagnóstico do médico competente não interfira em sua reabilitação, assim como não venha desencadear novas crises; atender no auto atendimento pois não há necessidade de digitação freqüente, visitar clientes, marcar visitas e dar informações; prestar atendimento no auto atendimento, atender telefone, marcar visitas, dar informações; qualquer atividade que não force a área lesionada; prestar orientações nas áreas de atendimento, evitando escrever e contato com digitação em máquinas e computadores, de forma a nessa período tomar conhecimento de novas rotinas da empresa; qualquer atividade que não provoque risco à área lesionada; assessoramento; deve tentar um pouco de tudo e verificar o que não é compatível; atendimento, organização de documentos, controle do trabalho, acompanhamento, consulta ao computador; atender telefone, fazer ligações; atendimento ao público, orientações, não pode digitar, fazer vendas, telemarketing, abertura de contas, montar dossiês, circulando nas filas, direcionar os clientes para o segmento adequado; atender público, telefone, não dá para escrever, digitar, mais contato do que manual; atendimento; atendimento ao balcão e telefônico; não pode digitar, carregar peso, pode atender o balcão, telefone, ajudar o colega com informações; depende do tipo de restrição, de tudo desde que não seja repetitivo, talvez não possa digitar, com pausas e equilibrio pode fazer tudo; qualquer coisa desde que não sobrecarregue o membro lesionado. 
6- Existe algo em que você possa contribuir para a reabilitação do colega?

Talvez, dependerá de oportunidade e motivação, posso ajudar contribuindo com sugestões e execução de algumas tarefas, dentro do possível; sim posso cooperar com o colega ajudando-o no que for preciso; não que eu conheça; creio que os gerentes poderão encaminhá-lo para o serviço certo; colaborando com ele no decorrer de suas atividades para sua reabilitação se torne positiva; apoio moral e físico; criando um ambiente favorável; ajudando em determinadas tarefas; colaborar para ele se sentir bem - vindo ao trabalho e ajudar no que for possível para que isso se torne realidade; fazer com que ele se sinta bem vindo ao trabalho e ajudar no que for possível para que isso se torne realidade; fazer com que ele não se sinta constrangido, mostrando que ele, apesar de não poder realizar algumas tarefas, a agência é suficientemente grande e com certeza poderá exercer outras funções sem comprometer sua saúde; incentivá-lo ao trabalho e ajudar na atualização de seus conhecimentos para seu desempenho no trabalho; incentivá-lo ao retorno ao trabalho e atualizar seus conhecimentos para o bom desempenho de seu trabalho, motivá-lo; sim, não o discriminando e procurando ajudá-lo sempre que possível em sua nova função; prestando esclarecimentos sempre que necessário e dando apoio a ele nesse período; tanto ajudando em sua função, quanto em respeito e não discriminação; chamar a atenção para seus limites; posso dar apoio moral, mas não de serviço porque não é do meu dia - a - dia; recepção, acolhimento, acho que mudou hoje, as pessoas tinham medo de falar que tinham LER; incentivar a pessoa, procurar coisas positivas; estar fora mexe com o psicológico, nós da agência não temos problemas com o gerente, ele é super aberto, ambiente tranqüilo; acho que vai ser bem recebida; boa receptividade, tentando fazer se sentir melhor; não ter preconceito, aceitá-la e fazê-la entender que ela é necessária à unidade, principalmente pela falta de recursos humanos, o trabalho gratifica o homem; espírito de solidariedade; boa recepção, levantar o moral; sempre um pouco a gente ajuda, se abrir para recebê-lo; solidariedade e deve haver situações em que eu possa ajudar.

7- Qual o seu sentimento em relação a isso?

É um risco que todos os funcionários estão correndo e posso ser a próxima a estar nesta situação; pode acontecer com qualquer colega; colaboração com sua recuperação e prevenção; é importante readaptar o empregado no trabalho pois somente o fato de estar 
parado e o sentimento de ser inútil, pode estressá-lo, o que prejudica a sua recuperação; solidariedade com relação ao colega e de prevenção com relação aos demais que ainda estão com o problema; acolhimento; sentimento de prevenção quanto a tomar cuidados para que não venhamos sofrer com o mesmo problema; solidariedade; para poder trabalhar bem, precisamos estar $100 \%$ portanto todo e qualquer cuidado é indispensável, trabalhando excessivamente e de forma incorreta, podemos prejudicar nossa saúde e apesar de todo o dinheiro que pudermos obter, com certeza não poderemos comprar saúde depois que o mal estiver feito não há como voltar atrás; satisfação em saber que a pessoa pode retornar à agência é sinal de que ela está se recuperando; fico satisfeita em saber que a pessoa pode retornar ao convívio profissional; deveria haver um maior cuidado em relação à prevenção da LER; satisfação ética e trabalhista por estar ajudando um colega e contribuindo com o desenvolvimento de um profissional e a afirmação dos programas da empresa; minha sensação em relação é a de que a empresa necessita buscar uma ação corretiva digo, preventiva e os funcionários alertar quando dos primeiros sinais de incômodo que surjam; ela tem que voltar, se o médico falou que ela tem que voltar; a empresa presta um bom atendimento agora está em evidência antes não se preocupava muito; acolher, receber legal, respeitando limitações; é difícil o retorno psicologicamente tem a ver a ajuda dos colegas fazer com que esta pessoa se sinta bem; solidariedade, antes estava como eu, muito serviço, pressão psicológica talvez eu possa estar na mesma situação; difícil para a pessoa; satisfeita em saber que alguém que tinha um problema tem condições de retornar; dependendo da gravidade do caso, deve ser complicado, pela pressão que vem de fora é dificil de administrar; a pessoa sem capacidade se sente muito mal e um grupo de apoio vai ajudar, gratificante; sensação positiva, é bom quando a gente pode ajudar uma pessoa; se a pessoa tem condições ela tem que voltar, se a pessoa estiver doente vai ser mais dificil, mas se ela não estiver ela vai ficar irada em voltar, dependendo do caso.

8-Outras observações: a empresa atualmente tem empregado tantas pessoas deficientes físicas como cegos, surdos, paraplégicos, porque não aproveitar os empregados que já fazem parte do quadro funcional, encaminhando-os para serviços adequados ao seu tipo de problema?; deveria se divulgar com mais freqüência os malefícios da LER, formas 
de se evitar, etc; dar maior ênfase; compreensão e respeito por parte da chefia e gerentes não somente dos colegas; quando retornar ao trabalho o mais importante é treinar a pessoa, pois na nossa empresa estão acontecendo muitas mudanças e a maioria não tem o conhecimento das mesmas; criar um comitê interno livre, formado por funcionários de todos os setores e da GIBEM na busca de soluções de curto, médio e longo prazos; LER para pessoas que são muitos tensas, antes tinha muita discriminação e saía de licença era para quem não queria trabalhar.

O resultado da pesquisa foi exposto aos participantes do grupo de atenção, como forma de apresentar os sentimentos e pensamentos dos colegas que iriam recebê-los nas unidades e tentar diminuir o grau de ansiedade com este retorno, mas a experiência foi individual e cada pessoa tinha o seu quadro de dor instalado e as suas características próprias para o enfrentamento da situação. 


\subsection{Quanto às entrevistas realizadas, utilizando-se a metodologia do Discurso do Sujeito Coletivo}

\subsubsection{Quadro Resumo do $1^{\circ}$ Tema:}

\section{LER: a vivência que não se esquece}

\begin{tabular}{|c|c|}
\hline $\begin{array}{l}\text { 1.A As pessoas atribuem } \\
\text { diferentes causas para o } \\
\text { adoecimento. }\end{array}$ & $\begin{array}{l}\text { 1 a Idéia Central: "Faltam informações sobre as LER." } \\
2^{\mathrm{a}} \text { Idéia Central: "O ambiente, o mobiliário e as tarefas } \\
\text { contribuíram para o adoecimento." } \\
3^{\mathrm{a}} \text { Idéia Central: “ Existem características pessoais } \\
\text { identificadas como causadoras de LER." } \\
4^{\mathrm{a}} \text { Idéia Central: " O gerente também foi responsável pelo } \\
\text { adoecimento." }\end{array}$ \\
\hline $\begin{array}{l}\text { 1.B Seqüelas: uma história } \\
\text { de dor }\end{array}$ & 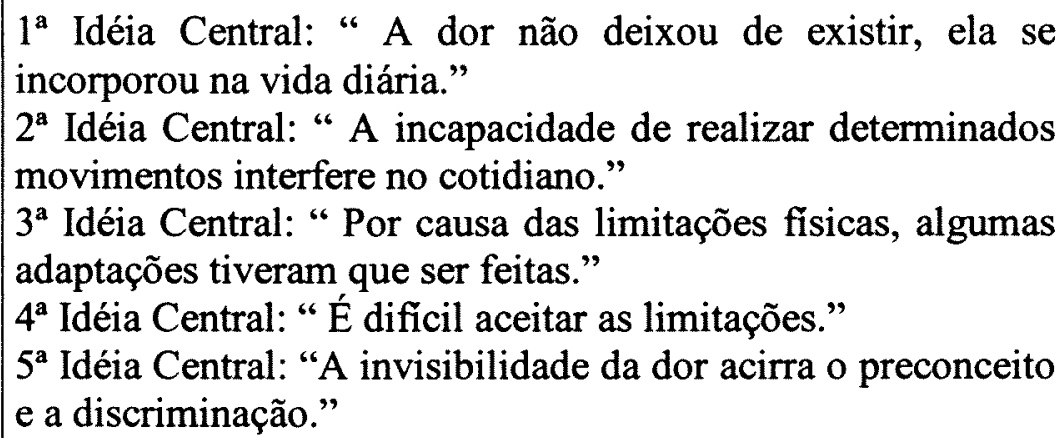 \\
\hline$\frac{1 \mathrm{C} \mathrm{O} \text { aumento da dor } \mathrm{e} \mathrm{o}}{\text { tratamento. }}$ & $\begin{array}{l}1^{a} \text { Idéia Central: "Ocorreram dificuldades com o tratamento, } \\
\text { trazendo o aumento da dor." }\end{array}$ \\
\hline
\end{tabular}




\section{LER: a vivência que não se esquece.}

\section{A. As pessoas atribuem diferentes causas para o adoecimento}

\section{1" Idéia Central: "Faltam informações sobre as LER."}

DCS (E1; E4)

Por mim assim, foi até... por falta de informações e... como posso dizer, assim... poderia ter me prevenido mais...

Antes de eu me afastar, eu tive amigas que haviam desenvolvido LER e o que a gente via era uma folha com uns desenhos de ginástica que a gente tinha que fazer a cada dez minutos depois de tantas horas, dá um descanso, tal.... mas isso era muito precário... então eu não vejo uma política séria, nesse caso, pelo menos até quando trabalhei.... eu não tinha visto uma política séria....

$2^{\mathrm{a}}$ Idéia Central: "O ambiente, 0 mobiliário e as tarefas contribuíram para o adoecimento."

\section{DSC (E1;E3)}

Mas aqueles movimentos, às vezes postura, talvez tudo isso tenha contribuido para estar desenvolvendo, talvez tenha tido uma propensão para isso. A minha baixa estatura, $o$ mobiliário inadequado, tudo isso contribuiu.

E acho que a partir do momento em que você começa a trabalhar com pressão, isso interfere no teu fisico. Existia na autenticação uma cobrança, eles faziam a contagem pela autenticação e nem sempre aquilo lá era a realidade que demonstrava, porque às vezes você dá entrada de dados.

E eu fui caixa durante um tempo. Aliás, foi lá que começou a doer meu braço. E foi uma coisa assim, que eu sempre fui empurrando lá a gente digitava muito... fazer cálculos, você insere os dados todos no micro e é um monte de coisas, tinha dia que saía de lá com o braço duro. Assim, ou você estava no micro, ou você estava escrevendo, foi ai que eu sai de licença. 
E quando tinha aqueles móveis antigos.... eu sentia dor, mas a partir do momento que mudou, com esses móveis agora, aí eu piorei. Eu sentia muito mais dor nas costas, nossa muito mais.

$3^{a}$ Idéia Central: “ Existem características pessoais identificadas como causadoras de LER."

DSC (E1;E7; E10; E12; E13; E14; E16)

Eu sou meio agitada. Eu já percebi que os mais propensos a ter LER, são os mais agitados, eu mesma cheguei a esta conclusão de ver as pessoas que querem fazer tudo mais rápido.

Além disso as minhas coisas estão sempre em ordem... aonde eu ponho o meu visto e meu carimbo eu tenho certeza do que eu estou fazendo. Eu também não sou de ficar esperando nada dos outros, que aliás esse é um grande problema que eu tenho que eu acho que uma parte que eu fiquei doente é isso, querer fazer um monte de coisas, sem me preocupar comigo. Eu já melhorei muito do que eu era, antes de ficar doente foi por desconhecer o meu limite, eu quero passar além muitas e muitas vezes.

Então meu ritmo, não sei se porque eu fui caixa, é meio acelerado... eu não gosto de não fazer... enquanto isso eu fui vivendo, um pouco é culpa de mim, de não falar não.

Tanto que eu até acho que o que eu tive de LER, né, que eu desenvolvi porque eu era rápida, eu era canhota... eu me torcia toda para trabalhar e mesmo assim eu conseguia trabalhar com muita rapidez.

Eu sempre achei que eu poderia fazer tudo, tudo, tudo que aparecia na frente eu poderia fazer, só que vai sobrecarregando de uma tal maneira.... e eu vivo me policiando para isso não acontecer, mas isso acontece, de perceber que você passou uma tarde inteira sem ir dar uma arejada, sem ir ao banheiro, sabe eu sou muito envolvida no trabalho.

\section{$4^{a}$ Idéia Central: “ $O$ gerente também foi responsável pelo adoecimento." DSC (E6; E9; E15)}

Tudo o que eu passei com a LER foi por causa do gerente. Foi a pior fase da minha vida, uma coisa que você não quer para ninguém. Eu passava noites e noites sem dormir, 
porque eu não queria acordar para trabalhar no dia seguinte. Naquela época nem existia a palavra assédio moral. Depois de tanto ler a revista bancária eu descobri que tudo era um assédio moral. Mas olha, como é horrivel, horrivel, nossa você se sente assim, para baixo, eu queria morrer.

E antes de sair de licença, o gerente já tinha me tirado do caixa. Ele tinha me deixado no atendimento, porque antigamente assim, atendimento era castigo, então acho que ele queria me punir. Eu ficava reto direto, ficava filas e filas imensas e lá era um gerente ordinário, desculpe a palavra, mas ele era... uma vez teve até uma moça que desviou dinheiro .... me fez ficar e pegar aqueles sacos de lixo enormes que tinham lá e procurar a APA, sabe o pagamento do FGTS que tinha sumido ..... eu comecei a pirar judiaram muito de mim naquela agência.

Então eu acho que um agravamento foi a mudança da gerência. Veio um gerente... tudo que ele fazia, ele pedia para todo mundo, então ninguém fazia nada completo ... no meu entendimento, no caso eu não termino nada, eu começo, paro, começo, paro e isso me afeta... porque eu começava a fazer um serviço e ele me pedia outra coisa, já parava. Ele não fazia nada, nem pegar relatório ele pegava. E eu acho que o que me agravou foi essa parte emocional, sei lá, talvez do perfil dele.

\section{B Seqüelas: uma história de dor}

1 Idéia Central: “ A dor não deixou de existir, ela se incorporou na vida diária."

DSC (E1; E2; E5; E7; E8; E10; E 11 E13; E14; E15; E16)

Nossa, tinha dia que eu não sei como eu conseguia ir trabalhar. Assim eu acho que a dor não vai melhorar nunca... eu estou fazendo com que essa dor faça parte do meu cotidiano, uma dor que não afete a minha vida.

Como várias vezes já aconteceu de eu estar morrendo de dor, cliente que já é conhecido falar: Nossa, o que você tem? Ah! Estou com muita dor! Ah! Então fica aqui um pouquinho, finge que você está atendendo! Então você vai nessa base, vai se enganando e enganando que está tudo bem..... 
Então eu percebo que em momentos de tensão eu começo a sentir aquelas dores... não é na mesma proporção, porque às vezes quando tinha formigamento eu tinha que acordar de madrugada que estava sentindo duro, nos dois braços....

Mas eu ainda estou fazendo tratamento.... mas eu tenho dor no polegar, que eu não tinha, eu tenho dor no ombro que eu continuo... e o ombro me dói de vez em quando, porque onde eu tenho minha maior restrição é no ombro.

E a dor é sempre, é constante e do lado esquerdo ela é bem forte... mas ai dá a dor e depois passa e fica sem doer, ai chega outra hora e dá a dor assim... só que a dor não termina e eu não sou de reclamar .....

Então meu braço ainda dói, ainda dói muito, mas é a hora que você tem que aprender... eu fui no médico... estou fazendo fisioterapia e eu tenho que fazer ginástica, mas não dá tempo .... quer dizer... eu sinto muita dor direto, mas a gente se acostuma com a dor.... eu continuo levando ela.... eu tenho dor.

E neste contexto geral foi dificil, porque eu ainda sinto dor, tenho sentido. De um ano e pouco assim, todo dia, tem época que é mais, logo que eu comecei, eu fiquei muito tempo em pé, ai começou a me dar dor na perna... ai começa a dor nas costas, dor nas pernas... nos ombros, nos braços.

Agora .... coisa piorou ainda mais, né. Desde que eu retornei eu não tive um periodo assim... que não provocasse um pouco mais de dor.

E nos últimos dias eu tenho sentido muita dor... eu fiquei com a mão esquerda doendo tanto que eu não conseguia nem levantar a mão para pentear o cabelo.... ai eu imaginei que deveria ser aquele arquivo enorme, com aquelas caixas gordas de processo que não cabem mais.

$2^{a}$ Idéia Central: “ $A$ incapacidade de realizar determinados movimentos interfere no cotidiano."

DSC (E2; E6; E8; E9; E11; E12; E14)

Tem coisas que eu não consigo fazer... e continuo sem conseguir .... eu adoro cozinhar e fazer coisas elaboradas... e você ficar batendo a massa, mexendo, fazendo 
coisas assim delicadinhas, já não tem mais jeito. Mas... Ah! Força ... tenho que abrir um refrigerante, eu não consigo, uma garrafa de água, perde um pouco a força na mão.

Vou tomar banho eu não consigo ficar com o braço assim muito tempo, então tem que descer, então fica mais dificil fazer as coisas do dia a dia.... a gente vai criando, vai fazendo.... com certas limitações, com dificuldades.

Meus filhos, no final, eu acabo não carregando eles, né, como eles mereceriam. Quando eu sai de licença, eu não fechava uma torneira. Eu não faço mais supermercado sozinha, meu marido vai junto. Eu não consigo escolher uma fruta, eu começo a pegar, daqui a pouco não dá mais.

Eu falo com a mão, né, eu não aguento, dói para falar até.... que eu falo mexendo a mão, me dói a mão para conversar eu vou ter que me segurar, prender a minha mão em algum lugar para não doer. Então eu não faço mais nenhum esforço, não carrego mais nenhuma sacolinha, eu não carrego mais.

E eu não posso falar que melhorou, por exemplo se em casa eu resolvo fazer um almoço, alguma coisa, eu tenho que tomar remédio.

3a Idéia Central: “ Por causa das limitações físicas, algumas adaptações tiveram que ser feitas."

DSC (E9; E11; E12)

Por causa da LER eu adaptei toda a minha vida, eu mudei um monte de coisas em função, assim de eu não precisar pegar condução, não precisar pegar carro, eu não agüento ficar num ônibus segurando em lugar nenhum, no metrô, dirigir nesse trânsito, também dói tudo, então o que é que eu fiz, eu deixei tudo perto da minha casa, eu faço tudo a pé.

Então eu não pego mais ônibus, trabalho lá pertinho, porque eu tenho ainda problema para levar a mão para cima. E seu eu fizer vagarosamente as coisas, eu posso fazer tudo, entendeu? É só eu não ficar estressada, eu faço tudo, sabe? Se tenho que estender roupa, eu pego a escadinha subo, desço o varal e peço para o meu marido subir o varal, quando ele chega. Quer dizer eu procurei, quer dizer eu procuro ver as coisas que são boas. 


\section{4 'adéia Central: “ É difícil aceitar as limitações.”}

DSC (E3; E4; E5; E6; E9; E11; E14)

Eu tenho que me prender, mudar meu jeito de ser, né. Então são coisas que você vai se irritando no começo, né dá assim... sei lá você se sente mal e uma inútil e para um monte de coisas.

Você vai se irritando, você não consegue pentear o cabelo, não consegue ai você fica pior ainda, vai vestir o filho, não consegue, o braço cansado, então isso é muito ruim. E ainda meu emocional não é redondo, redondo. Mas o que ficou assim, dilacerado é uma coisa que eu preciso estar atenta, porque talvez eu não consiga assim... curar, né.

Muitos estão doentes e não conseguem mais voltar, tiveram que entrar na aposentadoria, não só pela aposentadoria, como tiveram todo um problema pessoal..... é preocupante.

Além disso você mesmo não consegue entender que você tem limitações e que você tem que aprender. Às vezes esquece o lado fisico e ai as dores começam a te mostrar que você tem que ir mais devagar.... mas aí a necessidade de você mostrar que você não é só braço, né, que você pode estar produzindo.... e se eu me proponho a fazer quero fazer direito.

Então no dia a dia você já sabe suas limitações, né, isso é que foi a coisa pior, você aceitar até onde você pode ir. Você aceitar que você tem uma limitação é também um conflito. Você achar que pode e não poder, né... você vai ficar lutando contra o seu corpo a vida inteira, não, não vai.... eu vou fazer as coisas conforme eu posso.

$5^{\mathbf{a}}$ Idéia Central: "A invisibilidade da dor acirra o preconceito e a discriminação."

DSC (E4; E8; E9; E11; E13; E16)

A pessoa sente uma certa hostilidade quando ela voltou a trabalhar .... quem nunca teve LER ou desconhece o tema, pode até pensar que o empregado não está querendo contribuir, existe todo um lado místico... e eu tinha operado.... eu não usava atadura e a minha operação ficou aberta.... a gerente chegou para mim e disse: Nossa, ainda bem que 
você operou a mão, não foi a cabeça! Para você ver o grau de discernimento das pessoas... achar que eu estava fingindo, achar que eu estava doente da cabeça....

Porque você olha assim, o pessoal fala parece que não tem nada, né, é uma doença abstrata... assim de fora parece que não tem nada... mas só você sabe, né, no seu dia a dia o que limita ou não. Mesmo assim os amigos, os vizinhos, né, o pessoal fala: Ah! Vou trabalhar no banco!... porque eles vêm que você pode andar, não tem nada que está te impedindo... assim são as pequenas coisas que você tem, né. As limitações no seu dia a dia. $E$ as pessoas não estão presentes para ver naquele momento.....

As pessoas acham que não é nada. E não é nada mesmo, eu estou podendo fazer as coisas, só que eu faço tudo com dor, né. As pessoas falam: Ah! Ficou três anos afastada! Ficou no bem bom!

Então você já é discriminado por um monte de coisas, né, porque é uma doença que não aparece, que ninguém vê, então tem gente que não acredita que exista. Tem gente que fala: Ah! Mas eu também tenho dor! Sabe, tem dor de todos os tipos. Isso você tem que explicar, é um absurdo você ter que ficar discutindo sua dor com alguém.

$E$ dentro de uma agência existe isso, ninguém gosta de alguém que está lá ganhando sem trabalhar, né. E agora acho que nunca mais ele (gerente) vai me dar uma função... porque corre o risco de me afastar de novo, né. Então também tem isso, né, nunca ninguém te dá nada... porque nunca um gerente vai dar alguma coisa para quem tem LER. Muito pelo contrário, te ignoram, sabe é o resto, o trabalho que ninguém quer fazer.... então você perde de todos os lados, sabe.

Então a pessoa... acredita quem quer. Mas que nem, a gente, a gente sabe como é, né. Então... é difícil falar, né, é uma coisa que a gente não quer para ninguém, para outras pessoas.... é muita dor, né.

E olha o que eu acho que me atrapalhou bastante foi essa coisa do... preconceito. tá? Eu acho que o pessoal fica te achando meio... com uma parte de lesionado, e eles não conseguem tratar você como um profissional que teve um problema de saúde e sim como uma pessoa que teve uma lesão, né.... e o grupo em si, ele tende a não acreditar muito... nas suas dificuldades porque é mesmo uma doença invisivel. 


\title{
$1 \mathrm{C} O$ aumento da dor e o tratamento
}

\author{
Idéia Central: " Ocorreram dificuldades com o tratamento, trazendo o \\ aumento da dor." \\ DSC (E2; E8; E10; E15; E16)
}

Agora o que me atrapalhou mesmo bastante foi o tratamento errado que eu fiz, né. E tinha o agravamento que foi uma piora e que... na verdade era o perito do INSS que iria analisar se era uma piora... ficou constatada a piora... e eu cai e quebrei a mão... só que na verdade o meu médico não considerou essa queixa ... e engessou minha mão por causa do dedão e esse ossinho aqui colou em cima do tendão. E dai teve que tirar, aí cortou o tendão e ligou de novo... agora a questão é que o tendão está preso aqui na cicatriz.

Então a dor foi crescendo e agora ela chegou assim, se instalou a ficou, né... então eu estou fazendo uma manutenção do tratamento, mas é complicado. Você fica naquela sua rotina... com horários, prazos, compromissos... você tem sua vida em casa... tem que estar conciliando as coisas, né... e isso me pega muito assim, né, excesso de coisas a cumprir...mas tenho que estar fazendo tratamento mesmo, né.

Sabe e é chato porque eu mobilizo a familia inteira para eu fazer fisioterapia uma vez por semana. Então é chato porque as crianças já ficam: Ah! Outra vez!.... eu acabo envolvendo minha mãe, pego taxi, tenho que ir, é dificil.

Só que tem dia, quando muda o tempo, por exemplo, que eu sinto uma dor...e eu não fiz ultrassom depois que eu voltei .... porque eu tenho medo do resultado..... 


\subsubsection{Quadro Resumo do $2^{\circ}$ Tema:}

\section{Questões e situacões que desfavoreceram a reabilitaç̃o}

\section{profissional}

\begin{tabular}{|c|c|}
\hline $\begin{array}{l}\text { 2.A A interferência da } \\
\text { organização do trabalho }\end{array}$ & 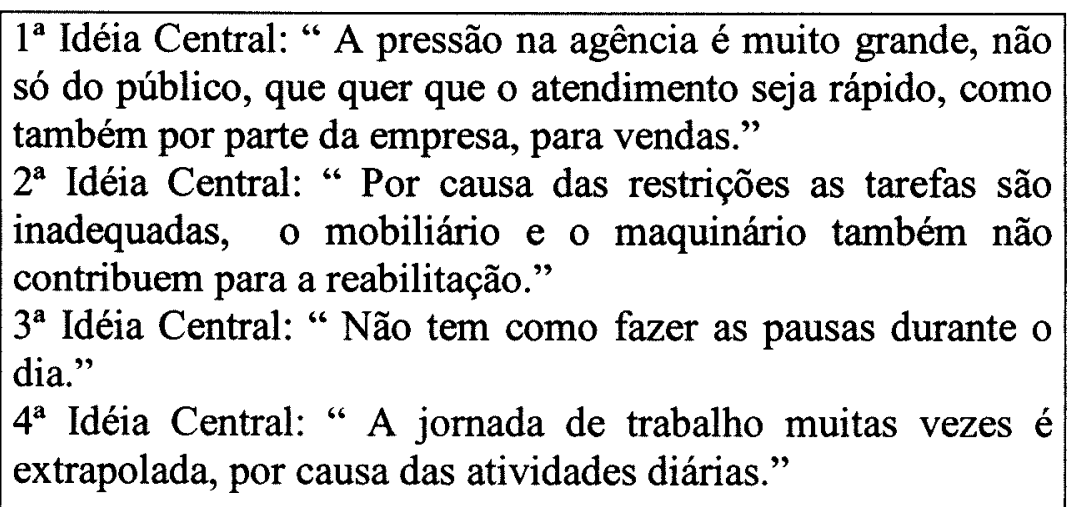 \\
\hline $\begin{array}{l}\text { 2.B Perfil do trabalho } \\
\text { bancário }\end{array}$ & $\begin{array}{l}1^{\mathrm{a}} \text { Idéia central: "A automação e as necessidades do mercado } \\
\text { financeiro descaracterizaram o perfil do bancário." }\end{array}$ \\
\hline$\frac{\text { 2.C As dificuldades no }}{\text { relacionamento interpessoal }}$ & $\begin{array}{l}1^{\text {a }} \text { Idéia Central: "O relacionamento com o gerente tem } \\
\text { contribuído para o agravamento dos sintomas e dificultado a } \\
\text { reabilitação." } \\
2^{\text {a }} \text { Idéia Central: " O relacionamento interpessoal com os } \\
\text { colegas teve uma repercussão negativa para a reabilitação." } \\
3^{\text {a }} \text { Idéia Central: "No começo, durante o estágio é tranqüilo, } \\
\text { mas depois tudo muda e as pessoas esquecem que ficaram } \\
\text { limitações." }\end{array}$ \\
\hline $\begin{array}{l}\text { 2. } \mathrm{D} \text { Os fatores que } \\
\text { trouxeram insegurança }\end{array}$ & 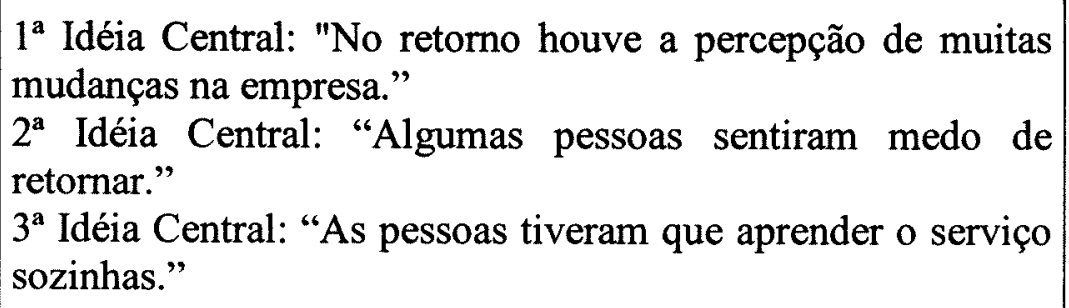 \\
\hline $\begin{array}{l}\text { 2.E O papel da empresa na } \\
\text { reabilitação profissional }\end{array}$ & $\begin{array}{l}1^{a} \text { Idéia Central: “A empresa não está preparada para receber } \\
\text { os empregados que se encontram em processo de reabilitação } \\
\text { profissional." }\end{array}$ \\
\hline 2.F O papel do INSS & $\begin{array}{l}1^{\text {a }} \text { Idéia Central: " O INSS que deveria cumprir um papel } \\
\text { importante na reabilitação, acaba atuando somente como um } \\
\text { avaliador nas perícias." }\end{array}$ \\
\hline
\end{tabular}




\section{Questões e situacões que desfavoreceram a reabilitaç̃o}

\section{profissional}

\section{A A interferência da organização do trabalho}

$1^{a}$ Idéia Central: “ A pressão na agência é muito grande, não só do público, que quer que o atendimento seja rápido, como também por parte da empresa, para vendas."

DSC (E1; E5; E8; E9; E13; E14; E16)

Na agência eu sofria muita pressão porque eu não tenho perfil para vendas e eu estava trabalhando sozinha lá.... eu estava com dificuldades... porque tem a classificação por metas e eles vão direcionando o pessoal para a linha de frente.

Porque tem a pressão externa que é o cliente... que está ali e ele não quer saber se você tem problema de saúde ou não, ele quer sair de lá o mais rápido possível. Então às vezes você está passando no meio do salão e o povo te cata, te puxa o braço... você fica num tipo de pressão muito grande.

Então sempre tem o público lá, que está te olhando e ele cobra, né, Ah! Empregado público está no telefone ou está conversando! Mas o telefone tem que ser atendido, tem que puxar ligação.... e na agência é assim você pegou tem que dar conta.....

$E$ você tem a pressão interna, que é aquela coisa de vamos, vamos, vamos.... o pessoal quer te empurrar... e foram agregando atividades, agregando atividades e a gente vai assumindo. Então isso é muita coisa para você ver num curto espaço de tempo.

E toda semana tinha reunião para cobrar vendas, vendas, vendas.... e eles sempre com aquela postura: Olha, quem não quiser se adaptar a nova realidade, a porta da rua é a serventia da casa!

E tem gente que fica empurrando seguro.... Ah! Sabe eu não tenho coragem. Eu, mesmo com pressão, eu não tenho coragem de fazer isso, nem ofereço.....

Eu acho que você acaba absorvendo isso.... eu acho que ninguém sabe o que é de quem, né, e isso acaba interferindo no nosso dia a dia, no trabalho da gente... e hoje o que 
eu vejo é que assim, a gente só está tapando o sol com a peneira.... você fica assim, parece um bombeiro.

E eles me mudaram de setor, me colocaram no atendimento a clientes, só que a demanda acaba sendo grande... acaba atendendo o não cliente, tentando captar o máximo possivel.

Não tem muita digitação, você digitava pouco, eu acho assim é muita coisa para você dar conta, você tem que estar atenta porque tem uma fila assim, cliente esperando, o telefone não pára de tocar... é muito corrido, um ritmo acelerado, então você não digitava muito, mas o ritmo era assim acelerado...

Na verdade você está sempre apagando incêndio: Ah! Agora é não sei o que, agora ... teve o FGTS... mas agora é adiantamento do crédito educativo e envolve... envolve toda a agência...

Porque tem o serviço e tem todos os clientes para atender né.... e não tem como você enrolar.... então se você pode atender, você vai atender ele, né. Aí você vai deixar todo o seu serviço e vai atender o cara, você vai fazer o serviço do atendimento, só que aquele serviço que você deixou, você tem que fazer e como você vai fazer dentro daquele periodo, você vai ter que fazer dois, três, quatro serviços ao mesmo tempo.

E um dificultador da gente trabalhar na retaguarda é que a gente trabalha basicamente com terceirizado, né. Então sobrecarrega, porque tem determinadas coisas que o terceirizado não pode fazer, você não pode dar sua senha, ele não pode ter acesso a alguns sistemas e ai você acaba fazendo... outro dia eu peguei o malote e fui contar dinheiro, era muito dinheiro... porque não é só digitar, é qualquer movimento que você tem que repetir várias vezes por dia.

$2^{a}$ Idéia Central: “ Por causa das restrições, as tarefas são inadequadas, o mobiliário e o maquinário também não contribuem para a reabilitação."

DSC (E3; E4; E11; E12; E13; E15)

Para mim o que às vezes me dá dor na mão é o mouse.... sem perceber você levanta o dedo. E também porque a gente não trabalhava com o material adequado.

Então assim, eu voltei com muita boa vontade... eu peguei uma fase de liquidação de contrato e comecei a vender seguro residencial.... eu vendia bem. Mas assim, foi por 
pouco tempo... porque de repente quiseram me colocar para fazer um trabalho manual, escrever envelopinho, preencher... sabe eu não acho um serviço menor, mas eu acho que a minha capacidade era para muito mais que isso... e outra era um trabalho manual, para quem está voltando de LER, ficar escrevendo o dia inteirinho, o dia inteiro escrevendo $e$ lidando com processos.

E na agência, a primeira vez que eu retornei, eu tinha que pegar alguns processos no alto e eu falei que não podia ficar com o braço no alto, ai falaram que iriam arrumar uma escadinha, né. E até eu sair de novo, a escadinha não arrumaram, né. E falaram que eu iria ter uma mesa, uma cadeira, tal um micro, inclusive eu fui na agência com o pessoal da segurança do trabalho e falaram que iria ficar num canto e chegou o estágio não tive mesa, cadeira, micro.

Lá a gente atende praticamente todo mundo que entra na agência, então eu abria conta... falaram que o SIRIC não era digitado lá, só que eu digitei muito SIRIC quando eu cheguei. E eu não quero creditar isso às coisas, mas eu acho que uma parte da culpa é porque não tinha mesa, não tinha nada direito, né.

Então assim, eu não manuseei tanto, o que foi ruim foi ficar no atendimento, porque além de ficar muito em pé, e isso afetou minha coluna... as pessoas acham que você não usa o braço, mas não é verdade. Primeiro tem gente que não sabe escrever... aí você vai escrever no balcão e não tem apoio.... na hora de digitar, por exemplo tem gente que não pode digitar, não tem senha, então você também tem que fazer isso, sem apoio nenhum, né. Então foi a questão do trabalho mesmo de ter que utilizar muito a mão, de ter que ficar sempre na mesma posição, eu acho que esse foi o motivo do agravamento.

E eles até tentam ajudar, dizem: Ah! $O$ atendimento acho que vai ser bom para você porque não precisa ficar digitando tanto! Mera ilusão, né. Porque eu estou no atendimento.... eu ficava $6,7,8$ horas em pé, só andando aquela agência inteira $e o$ atendimento extrapolou, comecei a fazer tudo naquela agência, eu resolvia problema dos caixas, resolvia problema dos clientes... e você precisa de um micro e ai ficou pior ainda, porque como eu não tinha micro, nem mesa, nem cadeira, não tinha nada... às vezes eu precisava usar o micro de alguém. Então eu fazia em pé, nas piores condições..... 


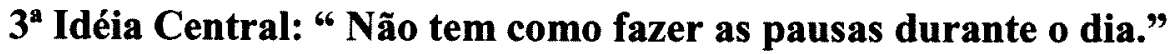

\section{DSC (E5; E16)}

Porque lá você não tinha como parar, estando com o público é diferente... no atendimento não tem como parar, é fila, fila, fila não pára. A pausa que eu faço é quando eu tenho que descer, pegar talão de cheque para cliente... essa pausa que se faz, mas parar no conceito que eu vejo de pausa, parar e não trabalhar, descansar, isso não acontece.... não dá para você se abster do trabalho para uma necessidade.

Na época o gerente não era dificil não, mas assim, por outro lado não foi feito nada assim de pausa. Então quando eu falei para ele que precisava de pausa, ele falou: Mas pausa é só para caixa! Então não sei se por falta de conhecimento ou... quem trabalha no atendimento não faz pausa, não. Eu acho que na minha condição de reabilitada eu tinha que ter pausa e eu não tinha, não, era direto.

Então eu já não estava conseguindo fazer pausas, porque eles estavam exigindo demais e eu já não estava conseguindo fazer. Estava desrespeitando o horário direto. Além disso eu ainda sinto dor.

\section{4a Idéia Central: “A jornada de trabalho muitas vezes é extrapolada, por causa das atividades diárias." \\ DSC (E6; E10; E14)}

No começo eu ainda estava fazendo tudo direitinho, mas com o movimento da agência, acabei largando o tratamento.... nessa época do plano Collor que estava trabalhando das 9 às 9 não tinha como, né, e era sábado também. Todo mundo está trabalhando 12 horas por dia, né. E a gente marca quando o gerente manda marcar, o que dá para pagar. E... eu saí de férias em junho, me chamaram uma semana antes. Eu trabalhei nas férias.

Então a gente nunca consegue fazer 6 horas, agora eu estou tentando fazer, né, porque eu perdi muito tratamento. Eu chego lá todo dia 8 e 20, 8 e meia e já começo a trabalhar, meu horário é das 9 às 3, e dificilmente eu consigo... eu não compenso, eu não faço nada. Eu estou trabalhando e eu continuo até terminar aquilo, né. 
Então quer dizer, no meu caso, o que acumula é assim estar na abertura e ficar praticamente no fechamento, como eu posso trabalhar 8 horas por dia, eu não trabalho, eu trabalho 11, 12 horas... eu entrei às 8 horas e trabalhei o dia todo, o almoço não dá para fazer duas horas de almoço, que é a hora que está pegando fogo na agência.

Porque o banco abre ao público às 9 horas, para abrir às 9 horas você tem que estar lá às 8 horas, por causa de tudo isso: tem que abrir o cofre, abrir a agência, abrir os sistemas, conferir, ai depois você tem que fechar, fecha às 4 horas, só que o pessoal continua lá dentro....

\section{B Perfil do trabalho bancário}

" A automação e as necessidades do mercado financeiro descaracterizaram o papel do bancário."

DSC (E8; E11; E12; E16)

E tem que ter produção, tem que ter produção e a gente fica aí no meio dessa.... coisa louca. Acho que o banco está no momento atual, está num momento de cobrança... essa coisa de venda, venda, venda, o empregado hoje é um vendedor, né.

E também eu vejo o lado da empresa... realmente um banco não precisa de gente que não pode trabalhar, porque o que eu vou fazer hoje numa agência sem usar o micro, não tem o que fazer, porque tudo você precisa das mãos, o que você faz hoje sem usar o micro, sem ter que digitar alguma coisa?

Então eu acho que a reabilitação não existe, pelo menos no banco, eu acho que em banco nenhum... quer dizer você acaba conversando com pessoas de outros lugares. Então em banco não existe reabilitação, porque você acaba voltando, não tem o que fazer num banco, pela natureza do trabalho... tudo acaba envolvendo dentro de um banco alguma coisa que você não pode fazer.

Além disso na agência hoje, o que importa para eles é vender, não importa você ser uma ótima operacional, se você não tem o perfil de vendas, você fica marginalizada.... e isso foi acontecendo nestes últimos dois anos, né. E agora, essa coisa ficou muito mais forte... várias vezes você recebe esse tipo de ameaça: Ou você vende, ou você vai ser mandado embora! 


\section{C As dificuldades no relacionamento interpessoal}

$1^{a}$ Idéia Central: “ $O$ relacionamento com o gerente tem contribuído para 0 agravamento dos sintomas e dificultado a reabilitação."

DSC (E9; E11; E12; E15)

Essa gerente atual ela é muito irônica, é uma coisa assim, ela faz as coisas, movimenta as coisas num momento que estava muito tumultuado, ela pôs mais lenha na fogueira e saiu de férias. Então ela mudou as pessoas, deixou um monte de gente que não sabia nada para trabalhar com as filas, né. Mas ali não dá dinheiro! A gente não faz as coisas só por que dá dinheiro. Então nesse momento aí a gerente mudou tudo e ninguém sabia nada, eu fiquei muito sobrecarregada, porque eu sabia um pouco mais ali...

E eu acabo ficando dividida, porque eu sei que tem alguém me esperando, ao mesmo tempo tem a fila, meus colegas que não sabem direito, o gerente precisa almoçar... é assim esse tumulto essa má vontade de atender o pobre, sabe.... isso me consome.... é uma pressão. Porque pode ser que quem dá dinheiro é aquela nata, mas se fica aquele clima de desconforto, nem a nata quer mais entrar ali dentro. Ninguém gosta de sentir as pessoas maltratadas.. Tem que ter um padrão de bom atendimento, não é atender bem um, e o outro meia boca. E ela quer que a gente atenda meia boca e eu não sei atender meia boca... eu tenho que gostar de trabalhar sem computador, sem mouse, com a tela piscando, com a luz em cima piscando, eu tenho que achar tudo bom, porque o bom não pode matar o ótimo. Mas e o terrivel, sabe....

Por exemplo o gerente de atendimento falou assim: Desde que você veio para cá, nunca mais ninguém subiu para reclamar nada aqui!... porque eu estava me matando lá embaixo... porque estava tudo perfeito, eu estava fazendo o que eles queriam né.

E o gerente falava: Ah! Ele vende errado, mas ele vende! Então para mim você é pior que ele, porque você não vende.... eu vendia também, mas em menor quantidade.... ele achava que você não usava todos os meios e eu não achava isso, eu nunca enganei um cliente meu com produto .... eu cumpro minhas metas, mas tudo com honestidade, se eu sentir que não dá para isso.... é até, sei lá.... uma questão ética, moral. 
Então para mim foi dificil este retorno.... hoje na minha agência tem meta individual porque tem relatório que vai para o gerente dizendo cada empregado o que ele fez...... um dia que você fica sem fazer nada é um dia que você vai embora estressada.....

Agora a gerente que está lá, que mudou de novo, ela não se afina muito comigo... esse relacionamento com o gerente é uma coisa que eu preciso amadurecer... então talvez seja este o único medo que ficou, que restou, sabe, que eu não consiga ter esse jogo de cintura diante da pressão... e eu aqui me arrastando com dor, meu filho me esperando, a fila enorme e você indo no cabeleireiro no meio do expediente, não dá meu! Ela também não é a única que faz isso. Se você quiser falar com ela tem que atravessar a rua e ir lá no salão....esse tipo de coisa que eu acho errado mesmo....

E a gerente não ajudou, como a maioria ela falava que eu não queria trabalhar, mas isso é normal, né, eu já vi com outros colegas também, isso é normal. E a gerente que me pegou no caso lá... ele comentou com outra pessoa... ela quer ficar na área meio para piorar e a gente não vai dar alta para ela, ela pensa que eu sou boba!

Então eu me senti muito insegura na época... eu passei aqui no PRT e eu não sei se ligaram para a gerente ou não, mas a partir daí minha vida foi um inferno na agência... passei por humilhação pública... eu estava a ponto de pedir demissão .... por conta da perseguição, de falta de caráter, de assédio moral, para não dizer outras coisas.... eu tive problemas com duas pessoas... e por sinal um era o gerente geral e a outra era a gerente.... e eu passei uma humilhação tão grande na frente de todo mundo que eu fiquei insegura, eu passei a me sentir assim.... uma pessoa totalmente incapaz, incompetente... foi um trabalho duro, foi um trabalho dificil, eu retornar e achar que eu tinha algum valor... então aquilo me deixou insegura... tudo isso contribuiu para o meu retorno não ser bom, né.

$2^{a}$ Idéia Central: “ $O$ relacionamento interpessoal com os colegas também teve uma repercussão negativa para a reabilitação."

DSC (E2; E4; E8; E12)

Eu voltei e fiz um acordo com o gerente lá, se eu poderia ficar um mês na retaguarda só para eu me ambientar.... só que aí eu me dei muito bem na retaguarda né... e 
ai começou a inadimplência .... né. Ai diziam: Ah! Vai precisar de alguém para fazer isso... Ah! Põe ela, ela não faz nada.....

E o relacionamento é diferente, porque na agência não dá tempo de se relacionar, você chega lá, mal fala bom dia, você não consegue conversar, entendeu! Então o relacionamento é bem profissional, bem restrito mesmo, né.

Então não sei se foi um choque que eu senti, talvez seja uma coisa mais pessoal... eu voltei e fui trabalhar num setor que eu era a pessoa mais velha do setor. Eu tinha colegas ali de 23 anos, de 20 anos, que é praticamente metade da minha idade... então eu não sei, se eu não consegui chegar até eles ou se eles me rejeitaram, eu não sei. Mas eu me senti muito rejeitada naquele retorno... eu me senti assim mesmo, eu me senti excluida... então eu participei de tudo na agência, eu sempre fui em todas as festas, em todos os churrascos... mesmo quando eu estava afastada, porque eu pensava nisso: Puxa eu vou ficar dois anos afastada e a volta como vai ser se eu não tiver contato com ninguém!.... mas eu não sei se isso valeu muito.....

$3^{a}$ Idéia Central: "No começo, durante o estágio é tranqüilo, mas depois as pessoas esquecem as limitações que ficaram por causa da LER."

DSC (E1; E5; E8; E10; E11; E12; E13; E14; E15; E16)

Acho que no começo foi bastante receptivo, mas no contexto geral isso é só no começo, depois você entra naquele rol. A gente retorna o estágio é de um jeito e depois, quando acaba o estágio e ai a gente retorna realmente, de pouquinho em pouquinho vai aumentando as coisas que a gente tem que fazer dentro da empresa.

E quando eu voltei não era mais a mesma gerente, era outro gerente e ele não estava muito a par, era outra realidade. Então você faz o que naquela hora tem mais necessidade. Ejá quebrou um pouco o que estava nas restrições.

Então durante uma semana todo mundo lembrou que eu estava voltando de uma licença, que eu tinha problemas só que depois começa: "Dá para você fazer isso!" "Vai fazer aquilo!" "hoje você fica não sei onde!"

E como tinha acabado de voltar, já me mandaram para outro setor, então isso te quebra. 
Ai eu voltei, só que assim a gente volta com muitas... restrições. Só que na hora que você está trabalhando... todo mundo esquece, até você esquece. Porque não existe nada ... que você não vá fazer, você tem que fazer não tem jeito.

$E$ a gente volta e a gente não consegue por as restrições e as pessoas também não vêem .... o lado negativo é que as pessoas olham para você e eles acham que você não tem nada...... e ai o acúmulo... começa a cobrar, a cobrança é muito grande, né.

Então você acaba engolindo um monte de coisas, além de estar morrendo de dor. né. E de estar sabendo que você vai fazer um monte de coisas que não pode, que você vai piorar, querendo ou não as dores vão aumentar, porque você vai fazer coisas que não pode.

Então você tem a primeira etapa que é esse preconceito.... numa segunda etapa.... eles deixam de acreditar que você precisa ter alguns cuidados com a saúde... e eles passam assim... parece a descreditar que você realmente tem dor... e eles passam a te questionar...

\section{D Os fatores que trouxeram inseguranca}

$1^{2}$ Idéia Central: No retorno houve a percepção de muitas mudanças na empresa."

DSC (E5; E7; E8; E9; E12)

O retorno em si foi dificil, você volta para a empresa e muda, a empresa estava mudada, muita coisa mudou do serviço. O meu retorno foi assim muito esperado, eu queria muito retornar. Mas eu não imaginava o jeito que ... estava, que seria assim tão dificil, não foi fácil retornar, foi como entrar numa nova empresa e começar tudo de novo sem saber praticamente nada.

Hoje você não faz nada sem o computador, e quando eu cheguei eu não sabia como ligar o computador, eu fiquei procurando o botão para ligar o computador.

$O$ medo que eu senti foi ter percebido muita mudança organizacional que eu não acompanhei e eu fiquei com medo de não acompanhar. 
Então ..... voltei no começo meio chocada, que eu voltei para o banco $e$ sinceramente mudaram os sistemas, mudou o SIGAT, mudou a Rede, mudou algumas coisas.

Além da readaptação em si ao trabalho, você tem que se adaptar a empresa, né. Que muita coisa mudou, ela está mais informatizada... você tem que reaprender. E sempre é um estresse, uma nova readaptação, agora que eu estou legal, tem que começar tudo de novo. Então assim, particularmente para mim é dificil todas estas mudanças, né.

Então esta estrutura da empresa talvez não esteja de acordo com o que eu sou... eu quero tratar direito as pessoas ... e o banco é ... não se preocupa nem um pouco com quem está na fila.

Então para mim, foi um choque. Eu encontrei muitas pessoas novas, os técnicos bancários, eu senti esse choque. Eu não tinha noção do que era um afastamento realmente, eu achava que você voltava e quando você voltava estaria tudo igual, mas realmente não é nada igual, tudo muda.

\section{$2^{\text {a }}$ Idéia central: "Algumas pessoas sentiram medo de retornar." DSC (E9; E12)}

Ficar afastada tanto tempo, eu acho o cúmulo! Mas eu tinha medo de voltar, um medo! E eu tinha medo de deixar meu filho. Eu comecei a saber muitas histórias, eu me afastei daquele primórdio, que eu trabalhei... com aquelas pessoas, aquela casa.... na outra agência eu fui muito judiada, eu tinha medo daquilo, eu não queria mais, sabe.

E eu senti muito medo o tempo todo de ser mandada embora. Eu sentia isso de ser mandada embora e desse gerente então, nossa! Eu morria de medo... todos os dias eu sentia medo, eu trabalhava com medo, eu trabalhava mal, tensa, preocupada.

Isso fazia parte do dia a dia, eu trabalhava apavorada porque eu pensava: Puxa, eu iá passei dos 40, aonde eu vou arrumar emprego agora... Mas é uma coisa horrivel, trabalhar com essa pressão.

Então eu sonhava, eu passei noites e noites sonhando ... depois do retorno eu sonhava, sonhava direto com o trabalho, eu sonhava com cobrança... foi um sofrimento... eu não desligava mais..... 
$3^{a}$ Idéia Central: “As pessoas tiveram que procurar conhecer o serviço sozinhas."

DSC (E10; E13; E15)

Então eu acho que foi complicado porque ai também me colocaram no setor de habitação, depois de 6 anos sem trabalhar com habitação. E me jogaram lá, não me ensinaram nada, ninguém tem tempo de ensinar nada....

Eu olho no manual e faço e eles dizem que tem um cursinho.... e eu nem isso fiz. E estou fazendo até para evitar o cliente entrar no site .... para mandar reclamação. Ele (gerente) me largou, ele falou se vira! Eu falei, num ponto é bom, no outro você fica meio estressada no começo.

Ai eu pedi transferência para outra agência que é do lado de casa, eu vou a pé. Mas quem trabalha em agência grande e vai para uma pequena é diferente, né. Mas para mim seria mais porque eu sempre fui caixa, então qualquer agência que eu estivesse eu teria que começar praticamente do zero e aprender outro serviço, né.

Aí eu tive que me virar sozinha, né. Ela é uma agência.... um pouquinho dificil, porque você ia pedir ajuda para os outros e ninguém gostava de ajudar ninguém.

Além disso, eu não sabia dar informação... além de causar um mal estar com o cliente, fazendo ele esperar, que tem que correr atrás da informação e de gente que está na correria e talvez não possa te dar a informação... você não tem um treinamento para trabalhar. Mas a insegurança foi... por não ter um treinamento no caso, não ter o conhecimento devido para exercer a atividade.

\section{E O papel da empresa na reabilitaç̃o profissional}

" A empresa não está preparada para receber os empregados que se encontram em processo de reabilitação profissional."

DSC (E8; E11; E12; E13; E14; E15)

Então eu acho que tem tudo isso, né, que às vezes eu acho que a empresa não está preparada assim para receber... fica no individual de cada gerente, de cada unidade estar 
recebendo, aceitando o empregado, até assim dar para ele atividades que ele possa estar desenvolvendo.

Agora se eu começar a falar: Ah! Isso eu não vou fazer porque tenho LER... ninguém vai me querer. E eu não tiro a razão... precisa alguém assim, porque tem meta para cumprir. Eu também não iria querer perder minha função, se eu fosse gerente, sabe. Porque eu vou defender um funcionário que tem problema. Quem vai querer saber disso? Ninguém quer saber disso... só a gente mesmo que pensa, né.

Então eu acho que a volta é... eu acho que em todos os lugares, você não encontra pessoas preparadas para te receber. Então na verdade você tem que estar preparada para voltar de alguma forma.... que nem, uma outra opinião minha, de conversar com vários colegas lesionados, acho que muita gente, se pudesse viria trabalhar numa divisão, né, onde não tem público.

Eu acho importante também... quando a gente tem um problema que é ocasionado pelo nosso trabalho, a gente tem que procurar outra colocação que não maltrate tanto, entendeu? E eles começam a cobrar muita coisa... e esse não é o objetivo quando a gente volta, a gente tem que voltar não da maneira que a gente saiu.

$E$ eu acho que a reabilitação tem que ser feita num lugar onde você possa desenvolver $e$ avaliar o desenvolvimento de uma rotina, né... e que você possa corresponder com ela... porque eu acho que tem que ver o perfil do funcionário, não é porque eu estou voltando a trabalhar que eu tenho que ser posta num lugar que o banco quer, só para readaptar... porque senão a gente não vai se realizar, né, como profissional.

\section{F O papel do INSS}

$1^{2}$ Idéia Central: " $O$ INSS que deveria cumprir um papel importante na reabilitação, acaba atuando somente como um avaliador nas perícias."

DSC (E4; E10; E12; E13; E15)

Eu também tinha um problema financeiro que eu não tenho o auxilio acidente... até hoje eu não entrei com ação contra o INSS... entrei aqui mesmo com aquele pedido de revisão no INSS, depois de um ano e meio eu recebi uma resposta negativa.... 
Agora... que eu acho que não ajuda na recuperação.... a pericia é muito angustiante, por causa... do que vai acontecer, o que não vai acontecer, às vezes você não esta em condições, você não sabe o jeito que o médico vai te tratar... e outra cada vez que você passa na pericia... você tem que repetir o tempo todo, porque lá no INSS eles têm a ficha toda lá, mas você tem que repetir tudo.... isso cria uma tensão....

Então... o pessoal do CRP me chamou lá e disseram que fecharam lá e acharam que eu poderia voltar. A moça lá falou um monte de coisas.... você tem que voltar, tem que trabalhar e agüentar a sua dor!

E na verdade eu não estava totalmente melhor. Eu estava com vontade de voltar a trabalhar, só que eu acho que eu voltei num momento em que eu não estava bem para voltar. E no meu caso, como o de outros, nós fomos praticamente obrigados a voltar. Eu acho que foi um problema entre o INSS e a empresa. Então eu tive que voltar porque eu tive alta, inclusive o médico do INSS disse para mim que estava muito tempo afastada, como se isso contasse para efeito de melhora ou não.

Então volta, trabalha, sai e vou levando a vida assim, até o dia que me aposentar. Eu não vou me recusar a fazer nenhum tipo de trabalho. Eu acho que é preciso pesar não só o lado psicológico, mas o lado fisico, antes de se conceder a alta, que algumas pessoas pedem, é legal voltar quando você está $100 \%$.

Mas se fosse para eu sair novamente, eu preferiria que fosse um afastamento que não voltasse mais. Porque não foi uma experiência muito boa, não foi a pior fase da minha vida, mas eu acho que poderia ter sido melhor, justamente porque eu tinha boa vontade para voltar. 


\subsubsection{Quadro Resumo do $3^{\circ}$ Tema:}

\section{Aspectos contributivos para o retorno ao trabalho}

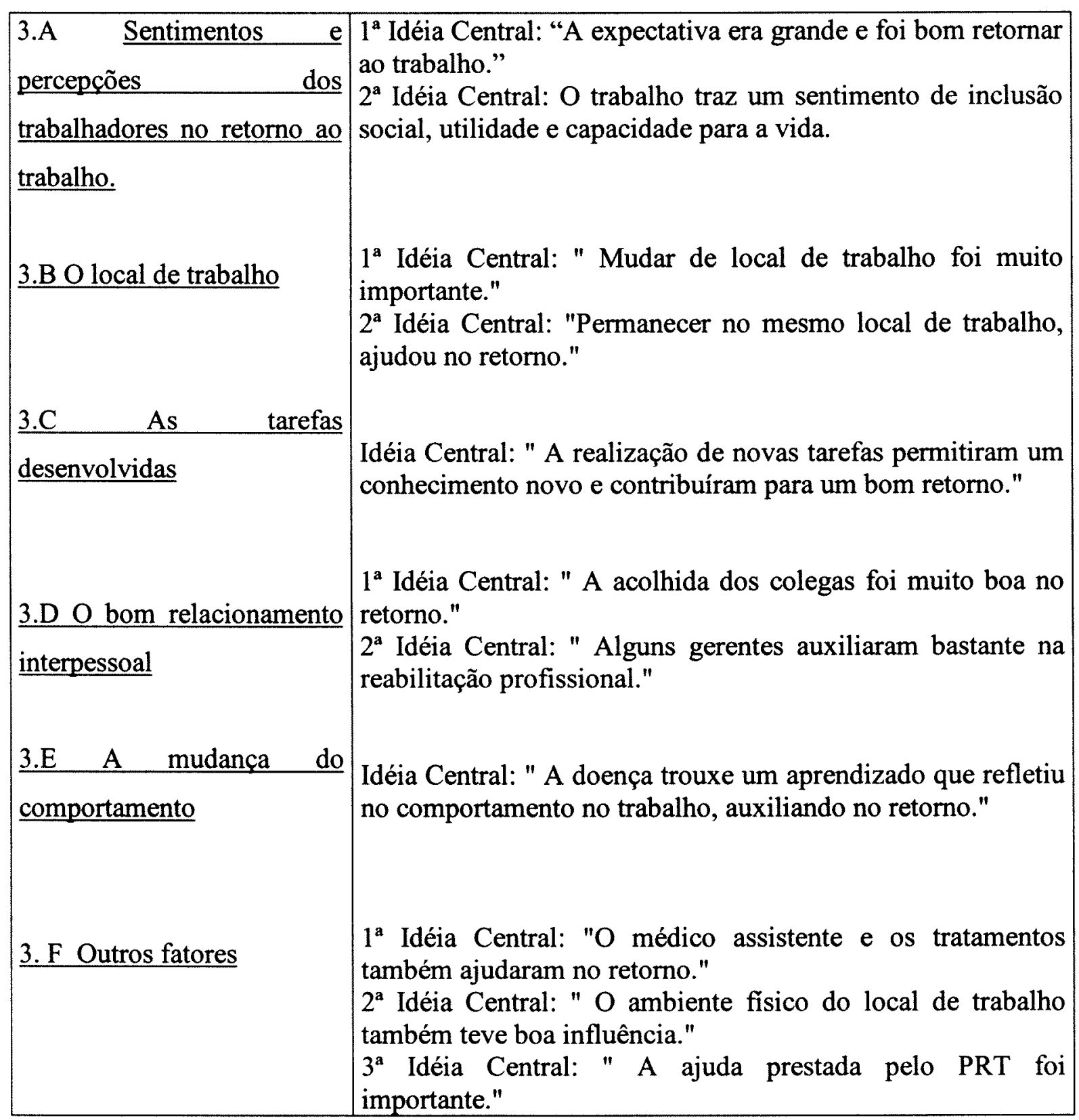




\section{Aspectos contributivos para o retorno ao trabalho}

\section{A. Sentimentos e percepcões dos trabalhadores no retorno ao trabalho}

1" Idéia Central: "A expectativa era grande e foi bom retornar ao trabalho" DSC (E1; E2 ;E3; E5; E6; E8; E12)

Na época gerou grande expectativa e eu vinha me preparando psicologicamente para isso, nesse meio tempo eu vinha fazendo os tratamentos, me cuidando, eu me preparei bastante.

Então eu acho que o meu retorno ao trabalho foi ótimo para mim e para a empresa. Eu não tive problema em nenhum momento. No período da readaptação eu realmente segui, foi seguido o que o INSS determinou: não digitar, não pegar peso, não levantar o braço. No começo eu fiquei muito em pé, aí a gente foi adaptando, então no período da readaptação foi tranquilo.

E eu gosto, não tenho queixa, o ambiente lá é bom, não tem pressão, tem assim, a pressão do serviço, entendeu? O serviço tem que ser feito. Eu acho que para mim, é muito melhor trabalhar e agora que eu não estou mais no caixa, então nossa eu digito, uso o micro o dia inteiro, mas é diferente, você não fica o dia inteiro em uma coisa, eu faço várias coisas.

$2^{\mathrm{a}}$ Idéia Central: “ $O$ trabalho traz um sentimento de inclusão social, utilidade e capacidade."

DSC (E2; E4; E5; E10; E12; E14; E16)

Eu queria voltar, eu nunca quis ficar afastada, eu sinto falta do trabalho. Eu conheço pessoas que ficavam psicologicamente acabadas por não estar contribuindo para a empresa. E quando volta a trabalhar ela começa a mostrar uma participação maior.

Assim, o fato de você ficar muito tempo parada vai te dando uma sensação de inutilidade. Então foi importante estar retornando ao trabalho para se sentir útil e mostrar que você ainda é capaz. 
E aprendi muito, antes eu achava que eu era uma pessoa inútil, eu não mexia no micro e achava que eu nunca iria aprender. Hoje eu sei o quanto meu trabalho é útil para as pessoas. E eu volto a me considerar uma boa profissional, acho que eu sou competente.

Porque quando você tem uma restrição, isso incomoda, eu fiquei psicologicamente abalada é uma sensação de inutilidade, a gente está impossibilitada de fazer as coisas. Mas eu me recusei a entrar em depressão e fui procurar saber as causas. E eu tive uma melhora acentuada e eu achei que eu tinha condições de retornar ao trabalho, de voltar a produzir.

E eu acho que uma das coisas boas de voltar é saber que a gente tem que reaprender, porque quando a gente perde algum potencial, a gente consegue desenvolver outro.

E também eu sempre trabalhei, e você ficar parada não é bom. Você fica meio excluida socialmente, você perde o referencial, então eu queria retornar ao trabalho.

\section{B O local de trabalho}

\section{$1^{a}$ Idéia Central: " Mudar de local de trabalho foi muito importante."}

DSC (E1; E2; E8; E16)

Então para mim foi bom, até porque mudei completamente de uma área tipo assim agência bancária, vim para uma área meio... Ter vindo para uma área diferente, acho que a vivência é diferente, então acho que para o meu crescimento foi muito bom, aprendi muita coisa.... acho que foi um aprendizado mesmo.

Então eu ter voltado para outro setor, eu não voltei para o setor de origem, eu já tive uma experiência de ter voltado para o lugar onde eu trabalhava e não foi boa. $A$ transferência em si, né.... acho que ajudou.

Então eu mudei de unidade na época foi bastante complicado... porque era uma coisa que tinha que acontecer, porque tinha umas pessoas que tinham duvidado demais do meu estado de saúde, né. 
$2^{\mathrm{a}}$ Idẻia Central: "Permanecer no mesmo local de trabalho, ajudou no retorno."

\section{DSC (E6; E10; E15)}

Eu já conhecia as pessoas, sabe, porque de uma agência para outra é diferente. Olha, ajudou porque foi a única agência que eu trabalhei na vida e eu ainda conhecia algumas pessoas... ai o pessoal que me conhecia falou: Pode trazer a ... sem susto, porque a gente conhece a ... e como é o trabalho dela. E para mim em nível de banco, o ambiente é bom. Eu não tive problema... aqui... sei lá se eu tivesse ido para outra agência....

\section{C As tarefas desenvolvidas}

Idéia Central: " A realização de novas tarefas permitiram um conhecimento novo e contribuíram para um bom retorno."

DSC (E2; E3; E5; E6; E10; E12; E15; E16)

Eu voltei a trabalhar num lugar legal.... num lugar tranqüilo e fazendo uma coisa que eu gosto de fazer, que eu sei que me dou bem, que eu sei que faço, que sei que faço direito..... E assim o que eu digito agora, nem se compara ao que eu digitava antes, por isso ficou legal para mim, porque se eu voltar a digitar o que eu digitava antes... mas aí é jóia, eu não tenho pressão, numa boa.

Então era um serviço que eu dominava, para mim foi importante voltar naquele setor porque como nesse período.... que eu fiquei fora, muita coisa mudou, né. E eu cheguei lá num ambiente novo... nossa deve ser o pior lugar do mundo. Mas não, não era assim.... ai o que acontece você é obrigado a cumprir metas, vendas e vendas, né. E a gente consegue bem no atendimento. A gente tem sido elogiado.... a gente chama pela senha e o pessoal fica todo lá sentadinho, e eu não me incomodo muito, né.

E na verdade assim, o ambiente ali é bom porque é um ambiente corrido e eu gosto de movimento, não gosto de lugar parado... então era uma coisa que eu já tinha trabalhado bastante, uma coisa da qual eu já tinha uma identificação... é uma coisa que eu gosto....

Então eu conheço bem, então eu sou bastante procurada para ajudar, para esclarecer, para ensinar, né. Então ser um ponto de referência, isso também é bom, né. 


\section{D O bom relacionamento interpessoal}

\section{1" Idéia Central: " A acolhida dos colegas foi muito boa no retorno." DSC (E2; E3; E4; E5; E6; E15; E16)}

Porque assim, o mais legal foi a acolhida, né, que o pessoal, que eu tive do pessoal né, eu fui muito bem recebida. Olha eu tenho muitos colegas dentro do banco, então é muito agradável você conviver com alguém que você gosta... então hoje eu acho assim. passaram uns dois anos, eu acho.... que eu consegui me readaptar.... eu estou me sentindo fazendo parte de novo.

Então é um relacionamento bom, a gente trabalha em equipe, tenta passar isso, a gente é uma equipe e um ajuda o outro.... senão a gente não chega em lugar nenhum. E... em nivel de relacionamento e de ambiente, isso nunca me afetou.

Os facilitadores que eu encontrei foram algumas pessoas que lidaram comigo na época do afastamento e fizeram.... e trabalharam comigo como profissionais antes da doença... esses acreditavam em mim e vivenciaram o problema que eu tive né.... sabiam do meu esforço para o retorno.

Eu acho que isso tudo, essa acolhida que eu tive lá, foi determinante mesmo para eu continuar. O pessoal me recebeu bem, nunca tive problema, é legal até hoje.

Eu ia muito na agência, não sei, acho que justamente para não perder o grupo, tanto é que quando eu retornei eu já tinha uma certa afinidade. Eu fiquei sabendo até, que o pessoal estava brigando porque queria ficar comigo! E eu conhecia todo mundo, não tive problema, foi assim bem tranquilo.

\section{$2^{\mathrm{a}}$ Idéia Central: " Alguns gerentes auxiliaram bastante na reabilitação} profissional."

DSC (E3; E6; E9; E15)

Não tive problema, o gerente me recebeu muito bem. Desde a época que eu comecei a trabalhar lá... sempre me dei bem com o gerente, então para mim foi tranqüilo, né.... ela sempre mostrou assim, sempre bem compreensiva, né.... 
Ela (gerente) procurou respeitar bem o meu ritmo e bem mesmo. Ela procurou tirar de mim esta questão de vendas... eu senti que ela me ajudou e eu procurei fazer com gosto, né... eu sempre senti boa disposição na agência... para comigo... a gerente, os colegas.... A gerente falava: Ah! O que você não puder fazer, passa para mim que eu faço.

\section{E A mudanca do comportamento}

Idéia Central: " A doença trouxe um aprendizado que refletiu no comportamento no trabalho, auxiliando no retorno."

DSC (E6; E7; E9; E10; E12)

Porque assim, uma das coisas que essa licença valeu é que o banco vai continuar sendo o que ele é, independente de eu chegar em algum lugar ou não, eu posso ser o que eu quiser ... então eu pensei não vou ficar tentando mudar um monte de coisas.

E bom, as filas é uma pressão.... Ah! O computador está quebrado! Eu dei um jeito ali na hora... assim a experiência é uma coisa que ninguém tira da gente, né. Eu tenho experiência de agência.... Então observando a mim, onde é que eu não aproveitei... eu aprendi isso.... olhar o outro, me colocar no lugar dele... aumentar a minha compreensão... então tudo que gente aprende na vida que é bom, se a gente aplicar mesmo, a gente vê que é bom.

Tudo que eu passei no retorno acho eu foi muito bom, porque eu vi né, as coisas que estavam certas, as coisas que estavam erradas, até assim, no meu comportamento mesmo, né... então a gente acaba mudando a postura da gente, né. Assim, eu mesma não me conhecia, eu achava que eu não tinha condições de vender, porque eu não gostava de vender. Ai eu percebi que não é bem assim, né. Você pode mudar também. Ah! você pode estar trabalhando para mudar. Antes me incomodava vender alguma coisa. Agora eu ofereço assim, o máximo que você pode receber é um não, né.

E todo médico que eu vou diz que esse problema no meu braço, eu vou ter que conviver com ele, então eu vou ter que aprender a fazer as coisas de outra maneira. Dá para fazer as coisas de outra maneira, entendeu? E agora que eu estou com essa 
consciência, eu estou tentando, né. Ainda não vou dizer que estou 100\%, mas acho que uns 40 já estou, né... eu vou fazer aquilo lá que mandaram, se der tempo eu faço o outro.

E eu sou uma pessoa que pego tudo muito fácil... então eu fui aprendendo tudo, lidando com o público, que é o que eu gosto. E eu acho que eu tive uma evolução muito boa profissional, porque eu á passei por tanto obstáculos desde que eu voltei e consegui superar todos eles, então eu acho que eu posso superar mais ainda... eu acho que eu vou chegar onde eu quero....

\section{F Outros fatores}

$1^{\mathrm{a}}$ Idéia Central: "O médico assistente e os tratamentos também ajudaram no retorno."

DSC (E3; E8; E10; E12)

$A$ (médica) deu o maior incentivo.... ela me deu bastante orientação, está sempre me perguntado o que eu faço.... E eu acho que o meu tratamento é a minha segurança de eu não voltar a ter mais as dores que eu tinha. Então eu acho que o tratamento que eu fiz foi muito bom, mas porque eu levei a sério... o tratamento para mim teve resultado.

$2^{2}$ Idéia Central: " $O$ ambiente físico do local de trabalho também teve boa influência."

DSC (E7)

Eu estou numa agência super bonita, com ar condicionado, toda envidraçada... tem flores, tem plantas... então são coisinhas que ajudam.

\section{$3^{a}$ Idéia Central: " A ajuda prestada pelo PRT foi importante." DSC (E7; E9; E15)}

E esse acordo que eu fechei na agência, isso é uma coisa do PRT que eu achei interessante ... e está valendo até hoje para mim. Uma outra coisa foi a indicação do médico que operou a minha mão... uma coisa legal, quem deu o telefone, que eu consegui, foi por aqui. 
E uma coisa que ficou para mim como muito bom foi ter participado do processo todo de reabilitação. Era uma coisa que eu estava bastante resistente, eu não estava assim aceitando a idéia com facilidade. E com o decorrer dos encontros eu fui sentindo que aquilo me ajudava. E (ajudou) eu acho que o PRT, aqueles encontros grupais. Porque assim, é lógico a gente sabe que não é o único na vida que tem problema, mas o fato de você estar com um grupo que também vai começar junto, né... eu acho que isso ajuda.... 


\section{6 - DISCUSSÃ̃}

Com base em todos os dados obtidos pode-se afirmar que a reabilitação, apesar de ser um procedimento complexo, foi possível de ser desenvolvida na prática. Os discursos apresentados demonstram a diversidade e contradições existentes nessa realidade, porém muitas pessoas conseguiram se adaptar em sua nova condição, representando uma melhora na qualidade de vida do indivíduo e uma diminuição do custo social.

A expectativa de retorno era grande para todos os trabalhadores e os resultados do retorno dependeram muito do local e das pessoas para ser positivo ou negativo. Aqueles que se prepararam tanto física, quanto psicologicamente para o retorno e encontraram pessoas receptivas nas suas unidades de trabalho, bem como tiveram tarefas bem negociadas $\mathrm{e}$ adequadas às suas restrições, foram melhor sucedidos no retorno. Diferentemente, aquelas pessoas que não conseguiram alcançar um equilíbrio físico e psicológico ou não obtiveram apoio dos colegas e chefias ou sentiram o impacto das mudanças organizacionais, não conseguiram ter um retorno positivo, se afastando novamente, ou no grau máximo se aposentando por invalidez.

Dessa forma pôde-se construir dois discursos diferenciados: o primeiro em que se apresentaram as questões e situações que desfavoreceram a reabilitação profissional e um outro em que foram informados os aspectos contributivos para o retorno ao trabalho. Esta discussão procurou abordar estas duas dimensões diferentes sobre a reabilitação profissional. É importante lembrar que, tanto os dificultadores, quanto os facilitadores ocorreram de forma simultânea e com interações dinâmicas. A divisão entre dificultadores e facilitadores e mesmo a divisão dentro de cada um destes aspectos, foi para o melhor entendimento e analise do conteúdo dos discursos. 


\subsection{Questões e situações que desfavoreceram a reabilitação profissional}

As questões que desfavoreceram a reabilitação profissional podem ser divididas em aspectos relacionados à interferência da organização do trabalho; influência dos aspectos psicossociais e dificuldades com as instituições que lidam com a reabilitação profissional (empresa, INSS, assistência médica).

Para se analisar a interferência da organização do trabalho é importante uma reflexão sobre a influência dos princípios tayloristas da administração científica nesta área. Fleury e Vargas (1986) destacaram que a administração empresarial abandonou em parte os métodos e técnicas tayloristas, mas não os seus princípios, que resumidamente foram assim citados: "...a interferência e disciplina do conhecimento operário sob o comando da gerência." (pg. 19); a seleção não deve ser de qualquer homem, mas do homem certo para o trabalho certo, além disso este homem obedecerá à instrução da gerência para o trabalho e para o descanso; o outro princípio estava ligado ao planejamento e controle do trabalho.

Betiol (1997) citando os mais recentes estudos sobre a organização científica do trabalho, defendeu que a taylorização continuou seu caminho, avançando para tarefas que pareciam impossíveis de serem afetadas como: trabalho em escritório, coleta de dados, empregos em banco, triagem postal e companhias de seguro que atualmente são divididas e padronizadas tal qual nos setores de produção em massa.

Dejours (1996) também mencionou o quanto o taylorismo invadiu o setor terciário devido ao intenso uso da informática. $O$ autor afirma que "... as atividades cognitivas, que distinguiremos da vida afetiva, serão situadas do lado do corpo e não do pensamento imaginativo investido na atividade de concepção." (pg. 162)

No presente estudo os sujeitos mencionaram alguns dos componentes da organização do trabalho que interferiram de maneira negativa no retorno ao trabalho, quais sejam: tarefas inadequadas; natureza, conteúdo e densidade do trabalho; ambiente e seus 
componentes; realização de horas extras involuntárias e falta de pausas para descanso; conseqüências da automação bancária e as exigências do novo perfil do trabalho bancário.

O primeiro aspecto abordado foi a questão das tarefas que, apesar de terem sido negociadas anteriormente, em muitos casos no dia - a - dia se tornaram inadequadas se consideradas as restrições adquiridas por causa das LER, como foi declarado neste depoimento:

"Não tem muita digitação, você digitava pouco, eu acho assim é muita coisa para você dar conta, você tem que estar atenta porque tem uma fila assim, cliente esperando, o telefone não pára de tocar... é muito corrido, um ritmo acelerado, então você não digitava muito, mas o ritmo era assim acelerado....."

O desconforto para os sujeitos da pesquisa não se encontrava nas tarefas que foram negociadas na requalificação, mesmo porque se analisadas as tarefas prescritas elas não são contra - indicadas para um trabalhador com restrições laborativas. A dificuldade estava na distância entre as tarefas propostas e sua prática que, no cotidiano acabaram se tornando inadequadas por causa do ritmo, da pressão e da necessidade de serem trabalhadores rápidos.

Ainda comentando sobre as tarefas, um outro aspecto que não foi mencionado diretamente nas entrevistas, porém foi citado no trabalho desenvolvido com o grupo de atenção, é a questão das limitações. Desde as primeiras reflexões sobre a LER, sejam acadêmicas ou não, os esforços repetitivos sempre estiveram atrelados ao desenvolvimento da doença, por alguns motivos, como por exemplo: as profissões relacionadas com as lesões são aquelas em que os trabalhadores realizam tarefas repetitivas, utilizando em excesso os membros superiores, entre outros. Os depoimentos dados pelos colegas dos participantes do grupo de atenção que estavam se preparando para voltar demonstram a preocupação de que a pessoa que sofre de LER não execute tarefas repetitivas. 
Desta forma, tornou-se senso comum que a pessoa que tem LER não pode manter esforços repetitivos, como se esta fosse a única, ou melhor a restrição mais importante para o seu caso. E, por este motivo, muitas vezes as tarefas são mal direcionadas, pois evita-se somente o esforço repetitivo, quando na verdade as lesões são causadas por um conjunto de variáveis que, se forem mantidas, poderão agravar o quadro. Por exemplo, muitos acreditam que um trabalhador com LER que esteja retornando ao trabalho possa exercer atividades de cobrança ao telefone, esquecendo que nesta tarefa também existe pressão pelo cumprimento de metas, e outras variáveis que podem ser causadoras de estresse, como o contato com o cliente devedor e que resultam em contratura muscular em virtude da tensão.

Em estudo realizado por Glina e Rocha (2003 a) procurando estabelecer uma relação entre dor muscular e exigências no trabalho, encontraram como principais fatores de estresse no trabalho, entre operadores de teleatendimento de um banco internacional: a rapidez em conflito com a qualidade; a densidade do trabalho com um grande volume de informações a memorizar; a fila de espera de clientes; a repetitividade da tarefa em contraste com a complexidade da mesma; falta de controle sobre o trabalho; a difícil relação com o cliente e as condições de trabalho.

Em outro artigo, Glina e Rocha (2003 b) publicaram estudo realizado com estagiários do setor de cobrança de um banco internacional, quando concluíram que entre os diversos fatores de estresse no trabalho, os de maior peso eram: a natureza do trabalho; o sistema de avaliação de desempenho e o relacionamento com os clientes; ocorrendo entre os estagiários o aparecimento de dor muscular e sintomas de estresse em pouco tempo de trabalho.

Estudos em ergonomia e psicopatologia do trabalho têm analisado a distância existente entre o trabalho prescrito, que são as tarefas e atividades determinadas e normatizadas pela administração empresarial e o trabalho real que é aquele desenvolvido na prática cotidiana, em que o trabalhador imprime os seus ajustamentos. Para Dejours (1996) o trabalho prescrito deve sofrer ajustes e interpretações para se tornar operacional, 
aparecendo como um jogo contra o sofrimento que advém da organização do trabalho determinado.

E o que aparece na fala dos sujeitos é esta dificuldade em lidar com a atividade real a ser efetuada. Ao cumprir suas tarefas, o trabalhador deve realizar os ajustes acima mencionados e, procurando atender aos clientes da melhor maneira possível, adota posturas que irão prejudicá-lo, acelerando seu ritmo de modo a cumprir sua tarefa e agindo assim freqüentemente não respeita suas restrições físicas:

"Então assim, eu não manuseei tanto, o que foi ruim foi ficar no atendimento, porque além de ficar muito em pé, e isso afetou minha coluna... as pessoas acham que você não usa o braço, mas não é verdade. Primeiro tem gente que não sabe escrever... ai você vai escrever no balcão e não tem apoio.... na hora de digitar, por exemplo tem gente que não pode digitar, não tem senha, então você também tem que fazer isso, sem apoio nenhum, né. Então foi a questão do trabalho mesmo de ter que utilizar muito a mão, de ter que ficar sempre na mesma posição, eu acho que esse foi o motivo do agravamento."

O segundo fator que pode ser analisado em relação à organização do trabalho, é o aspecto ligado à natureza, conteúdo e densidade do trabalho. No presente estudo, a atividade a ser desenvolvida pelos trabalhadores em questão exige autocontrole emocional, porque no banco o cliente está sempre correto e o bancário deve manter uma postura educada e paciente com o mesmo; concentração e atenção constantes, pois lidam com dinheiro, não só no caixa, mas durante as vendas de produtos costumam manusear as contas dos clientes no sistema, além de ter que prestar informações precisas sobre produtos e serviços do banco. Como no depoimento:

“E um dificultador da gente trabalhar na retaguarda é que a gente trabalha basicamente com terceirizado, né. Então sobrecarrega, porque tem determinadas coisas que o terceirizado não pode fazer, você não pode dar sua senha, ele não pode ter acesso a alguns sistemas $e$ aí você acaba fazendo... outro dia eu peguei o malote e fui contar 
dinheiro, era muito dinheiro... porque não é só digitar, é qualquer movimento que você tem que repetir várias vezes por dia."

Esta é uma situação comum . Procurando suprir a falta de recursos humanos, o banco contrata uma empresa de prestação de serviço. Porém existem tarefas que os terceirizados não podem assumir, considerando que o empregado do banco é quem será responsabilizado pelos erros cometidos. Assim, o empregado que perder dinheiro na execução de sua tarefas deve repor em prazo determinado no manual normativo, com recursos próprios e podem ser valores altos.

Sobre estas questões Seligman Silva (1992) mencionou que existem determinadas tarefas que, por sua natureza e conteúdo, se ligam à esfera psico - afetiva, especialmente as que exigem concentração por muito tempo, chamando a atenção para as atividades cognitivas, pois os avanços tecnológicos aumentam as exigências neste nível, o que combinado com outros fatores pode ocasionar um desgaste mental.

A terceira dificuldade mencionada pelos sujeitos diz respeito ao ambiente e seus componentes. Nos depoimentos as pessoas disseram que sentiam mais dor por causa dos equipamentos e materiais inadequados, espaços pequenos a serem divididos com outras pessoas, adoção de posturas inadequadas por causa das tarefas, entre outros motivos, como no depoimento:

"E eles até tentam ajudar, dizem: Ah! O atendimento acho que vai ser bom para você porque não precisa ficar digitando tanto! Mera ilusão, né. Porque eu estou no atendimento... eu ficava 6, 7, 8 horas em pé, só andando aquela agência inteira e o atendimento extrapolou, comecei a fazer tudo naquela agência, eu resolvia problema dos caixas, resolvia problema dos clientes... e você precisa de um micro e ai ficou pior ainda, porque como eu não tinha micro, nem mesa, nem cadeira, não tinha nada... às vezes eu precisava usar o micro de alguém. Então eu fazia em pé, nas piores condições....". 
Fisher (1996) definiu o ambiente físico e os objetos que o compõem como um "constructo social" (pg. 82), local onde estão inseridas as funções materiais e valores sociais. $O$ autor apresenta o espaço como um condutor das interações sociais e também como um processo que irá transmitir a mensagem de que o comportamento humano não é um sistema passivo. Em avaliação sobre a contribuição da psicologia ambiental, Fisher (1996) apresentou três importantes conceitos envolvidos no tema: território, espaço pessoal e apropriação.

O primeiro deles, território, é o lugar ocupado por uma pessoa ou grupo que, de certa maneira, torna-se "proprietária" dele, adotando comportamentos de dominação. Assim os indivíduos podem utilizar objetos, símbolos ou sinais para demarcar esta área e essa demarcação tem conotações culturais e sociais. Nas empresas, por exemplo, o local maior ou menor, fechado ou aberto, pode demonstrar a importância hierárquica do indivíduo dentro da organização. As funções de territorialidade são muitas: facilitação da organização e gestão das atividades; associa o tipo de comportamento esperado; fundamenta o desenvolvimento da identidade pessoal e social; auxilia a desenvolver confiança mútua entre seus ocupantes. Os sujeitos deste estudo que estão retornando ao trabalho também procuraram essa identificação com o local e a princípio têm a agência como um local de incertezas que vai tornar-se melhor a partir da socialização que é feita pelo grupo.

O segundo conceito é o de espaço pessoal que está relacionado com a zona emocional e sócio - afetiva, portanto trata-se de uma "fronteira invisível da pessoa" (Fisher, 1996, pg. 87). As funções do espaço pessoal podem ser assim descritas: sistema de defesa e proteção da intimidade.

Desta forma, o espaço de trabalho é um espaço pessoal, ou seja, quanto mais personalizado é um espaço, maior é o sentimento de autonomia, reconhecimento e individualidade e que a possibilidade de se ter um espaço próprio dentro do escritório é um importante elemento para a adaptação e transformação do local. Dessa forma, possuir ou não um espaço apropriado dentro da agência torna-se um facilitador ou dificultador para a 
reabilitação profissional, especialmente porque a pessoa está procurando uma nova identidade com o banco, pois ela não pode mais realizar as mesmas atividades que fazia anteriormente ao afastamento, por causa de suas restrições.

Conta a evolução histórica das atividades humanas que os espaços organizacionais no início do taylorismo eram rigorosamente divididos para a produção. Com a introdução de novos conceitos administrativos, os escritórios também se modificaram tornando-se mais amplos, com vistas à melhoria da comunicação. Porém conforme pesquisas apresentadas por Fisher (1996) esses espaços se tornaram fonte de estresse, pois impedem o recolhimento necessário, negando o espaço pessoal. Nos bancos, esse fator é piorado com a presença diária e constante do público externo. As atividades que necessitam de um grau importante de concentração são realizadas em meio à presença deste público, tornando-se um desgaste a mais para o trabalhador, como no depoimento:

"Então sempre tem o público lá, que está te olhando e ele cobra, né, Ah! Empregado público está no telefone ou está conversando! Mas o telefone tem que ser atendido, tem que puxar ligação... e na agência é assim você pegou tem que dar conta....". "Porque tem o serviço e tem todos os clientes para atender né.... e não tem como você enrolar.... então se você pode atender, você vai atender ele, né. Aí você vai deixar todo o seu serviço e vai atender o cara, você vai fazer o serviço do atendimento, só que aquele serviço que você deixou, você tem que fazer e como você vai fazer dentro daquele periodo, você vai ter que fazer dois, três, quatro serviços ao mesmo tempo."

Nas atribuições do bancário existem tarefas que necessitam de maior concentração como por exemplo a análise de processos ou na concessão de empréstimos. E estas tarefas ficam comprometidas na medida em que a prioridade é o atendimento ao público. $\mathrm{Na}$ prática o trabalhador não consegue terminar uma atividade completa, como no depoimento acima e, desta forma ele assume diversas outras tarefas decorrentes do atendimento ao público, acumulando tudo, com o serviço anterior. 
E por último o conceito de apropriação que se refere ao ato de tomar algo para si, mesmo que ele não lhe pertença; serve para orientação do comportamento que produz autonomia, tornando-se um "processo criativo de identidade que favorece a reunificação de si nos conjuntos sociais que têm a tendência de dispersá-la." (Fisher, 1996, pg. 89) Esta apropriação, para os sujeitos, foi dificultada na medida em que os trabalhadores assumiram tarefas de atendimento ao público, sem terem, pelo menos no início, um local específico de trabalho.

O outro aspecto abordado nos depoimentos foi com relação à realização de horas extras involuntárias e a falta de pausas para descanso. A exigência de atendimento ao público compromete tanto o cumprimento da jornada de trabalho, quanto a realização de pausas regulamentares, prejudicando os períodos de descanso, tão importantes para a recuperação física e mental, como no depoimento:

"Porque lá você não tinha como parar, estando com o público é diferente.... no atendimento não tem como parar, é fila, fila, fila não pára. A pausa que eu faço é quando eu tenho que descer, pegar talão de cheque para cliente... essa pausa que se faz, mas parar no conceito que eu vejo de pausa, parar e não trabalhar, descansar, isso não acontece.... não dá para você se abster do trabalho para uma necessidade."

“Então quer dizer, no meu caso, o que acumula é assim estar na abertura e ficar praticamente no fechamento, como eu posso trabalhar 8 horas por dia, eu não trabalho, eu trabalho 11, 12 horas... eu entrei às 8 horas e trabalhei o dia todo, o almoço não dá para fazer duas horas de almoço, que é a hora que está pegando fogo na agência."

"Porque o banco abre ao público às 9 horas, para abrir às 9 horas você tem que estar lá às 8 horas, por causa de tudo isso: tem que abrir o cofre, abrir a agência, abrir os sistemas, conferir, ai depois você tem que fechar, fecha às 4 horas, só que o pessoal continua lá dentro...."

Hassard (1996) apresentou dois paradigmas lineares: quantitativo e qualitativo. O primeiro domina atualmente o estudo sobre o tempo de trabalho como um bem limitado cujo valor aumenta à medida em que se rarefaz (pg. 180). A história do capitalismo 
industrial mostra que houve uma evolução nas relações de trabalho, quando a duração do trabalho substitui a tarefa na unidade de produção. Dessa forma analisando-se o processo de trabalho, o tempo primordial é o da produção, os outros tempos ficam à sua margem. No segundo paradigma, o qualitativo, o tempo está mais ligado a questões sociais e culturais baseadas em variados sistemas de avaliação do tempo, numa combinação de significados. $O$ autor apresenta algumas alternativas assumidas pelos trabalhadores para suportar as longas jornadas como: realização de ritos sociais; adoção de estratégias, nomeando hora de tarefas boas e hora de tarefas ruins, alternando os sentimentos com relação às atividades; distinção entre hora do patrão e hora do trabalhador; alternância no ritmo da produção. Assim o tempo no trabalho assume um papel primordial e todas as outras atividades que compõem a vida do trabalhador devem sofrer um arranjo em torno deste tempo, assumindo um valor monetário. É importante destacar o significado que cada trabalhador e o conjunto de trabalhadores dá para o tempo no trabalho, como por exemplo no depoimento a seguir:

"Então a gente nunca consegue fazer 6 horas, agora eu estou tentando fazer, né, porque eu perdi muito tratamento. Eu chego lá todo dia 8 e 20, 8 e meia e já começo a trabalhar, meu horário é das 9 às 3, e dificilmente eu consigo.... eu não compenso, eu não faço nada. Eu estou trabalhando e eu continuo até terminar aquilo, né."

O trabalhador assume para si as exigências das tarefas, não importando o tempo que leve para cumpri-las. A prioridade é sempre o atendimento ao público, mas sobram tarefas que na maioria das vezes não podem ser postergadas. E por isso, são sacrificadas as horas que deveriam ser dedicadas aos interesses pessoais como familia, lazer, estudo, etc.

Seligmann Silva (1992) analisando os aspectos na inter-relação trabalho - esfera mental destacou a estrutura temporal do trabalho como um dos componentes que podem interferir na saúde mental do trabalhador. Assim alguns fatores como duração da jornada, sua distribuição em turnos, folgas, dispositivos referentes às pausas, como quantidade, duração e qualidade, ritmos, pressão do tempo podem afetar positiva ou negativamente a saúde física e psicológica do trabalhador. 
O último aspecto mencionado pelos sujeitos diz respeito às conseqüências da automação bancária e às exigências quanto ao novo perfil do trabalho bancário. Nos últimos dez anos houve um incremento importante na automação bancária. As inovações tecnológicas têm permitido uma redução nos custos operacionais, além de proporcionar um aperfeiçoamento do processamento de informações e possibilitar um aumento na oferta de produtos e serviços aos clientes, o que sem dúvida contribui para o fomento da lucratividade.

Porém, a automação trouxe importantes conseqüências para a vida do bancário. Izumi (1997) informou que o ritmo do trabalho bancário foi intensificado, na busca de acompanhar as máquinas. Além disso, esse profissional se tornou dependente do sistema que apresenta falhas constantes, ocasionando atritos no atendimento ao cliente que dificilmente compreende o que está acontecendo.

Outra conseqüência da automação é o aumento do controle sobre o trabalho, pois é facilmente detectável a produção diária, como no depoimento:

“E tem que ter produção, tem que ter produção e a gente fica ai no meio dessa.... coisa louca. Acho que o banco está no momento atual, está num momento de cobrança... essa coisa de venda, venda, venda, o empregado hoje é um vendedor, né."

A necessidade de cumprimento de metas e a pressão interna (agência) e externa (clientes) foram mencionadas como um fatores geradores de grande insatisfação e desconforto:

"Na agência eu sofria muita pressão porque eu não tenho perfil para vendas e eu estava trabalhando sozinha lá.... eu estava com dificuldades.... porque tem a classificação por metas e eles vão direcionando o pessoal para a linha de frente."

“Porque tem a pressão externa que é o cliente.... que está ali e ele não quer saber se você tem problema de saúde ou não, ele quer sair de lá o mais rápido possivel. Então às 
vezes você está passando no meio do salão e o povo te cata, te puxa o braço... você fica num tipo de pressão muito grande."

“E você tem a pressão interna, que é aquela coisa de vamos, vamos, vamos.... o pessoal quer te empurrar atividade e a gente vai assumindo...E toda semana tinha reunião para cobrar vendas, vendas, vendas.... e eles sempre com aquela postura: Olha, quem não quiser se adaptar à nova realidade, a porta da rua é a serventia da casa!"

O novo capitalismo traz uma forma de atuação das organizações, em que foram eliminadas as camadas da burocracia e elas são agora pensadas como redes, pois tornam-se mais facilmente passíveis de serem decompostas ou eliminadas. Estes conceitos adentraram a vida pessoal dos indivíduos, e ninguém aceita mais as estruturas pesadas, tudo é flexibilização, tudo é passível de mudança.

Sennett (1999) expôs três elementos importantes da flexibilização do capital: o ataque à rotina burocrática e fragmentação do sistema, que possibilita a intervenção no sentido de tornar as instituições mais lucrativas, buscando sempre atender a volatilidade da demanda do consumidor; a especialização flexível é a antítese do sistema de produção incorporado no fordismo; a concentração sem centralização, ou seja existe o poder mas ele parece diluído, facilitando a ação de comando.

O controle será exercido através do estabelecimento de metas de produção para os diversos grupos da instituição e elas poderão ser cumpridas da maneira que se achar mais conveniente. Ocorre que é muito raro o estabelecimento de metas de fácil cumprimento. Normalmente os grupos são pressionados a produzir muito mais do que está em sua capacidade imediata. $\mathrm{Na}$ realidade, demanda e oferta não estão em sintonia com as metas, forçando os grupos à produção cada vez maior.

Esta é uma realidade no banco estudado porque as metas são estabelecidas pela alta administração que raramente ouve a opinião daqueles que estão na ponta. Dessa forma, existe muito desconforto quando o bancário tem que vender produtos para o atingimento de metas que ele sabe ser impossível. Além disso, como foi comentado pelos sujeitos, a 
capacidade de atendimento é menor do que a quantidade de clientes, existindo uma sobrecarga em alguns setores. E este é um fator dificultador, pois por uma questão política, a empresa não pode admitir um número maior de empregados acima dos já existentes.

Para atender esta nova situação houve uma mudança significativa na forma de organização do trabalho e no papel profissional a ser desempenhado pelo bancário. A nova maneira de atuação está mais voltada ao atendimento integral do cliente, o diferencial hoje está relacionado à qualidade do atendimento. Portanto existe a necessidade de um profissional com competência para dar informações gerais sobre produtos e serviços do banco e ter condições de prestar assessoria financeira ao cliente.

Este aspecto remete a uma situação apresentada pelos sujeitos como dificultadora, que é a mudança no perfil do trabalho bancário, como no depoimento:

"Além disso na agência hoje, o que importa para eles é vender, não importa você ser uma ótima operacional, se você não tem o perfil de vendas, você fica marginalizada.... e isso foi acontecendo nestes últimos dois anos, né. E agora, essa coisa ficou muito mais forte.... várias vezes você recebe esse tipo de ameaça: Ou você vende, ou você vai ser mandado embora!"

Segnini (1998), em sua análise a respeito deste novo perfil, colocou que existe hoje uma demanda por profissionais mais qualificados e nesse sentido a organização do trabalho exige a concepção de um trabalho polivalente, legando ao trabalhador o exercício de atividades em mais de uma tarefa, função ou posto. A autora acrescenta que a qualificação para o trabalho será resultado da capacidade do trabalhador de interligar conhecimentos e comunicação, uma vez que ele terá que se entender individualmente com o cliente e na eventualidade da ocorrência de um imprevisto, se articular também com colegas e chefias.

Os sujeitos abordaram essas novas expectativas a respeito dos trabalhadores bancários e sua expressão foi feita de forma angustiante: 
"O retorno em si foi dificil, você volta para a empresa e muda, a empresa estava mudada, muita coisa mudou do serviço. O meu retorno foi assim muito esperado, eu queria muito retornar. Mas eu não imaginava o jeito que ... estava, que seria assim tão dificil, não foi fácil retornar, foi como entrar numa nova empresa e começar tudo de novo sem saber praticamente nada."

"Hoje você não faz nada sem o computador, e quando eu cheguei eu não sabia como ligar o computador, eu fiquei procurando o botão para ligar o computador."

"O medo que eu senti foi ter percebido muita mudança organizacional que eu não acompanhei e eu fiquei com medo de não acompanhar."

"Além disso, eu não sabia dar informação... além de causar um mal estar com o cliente, fazendo ele esperar, que tem que correr atrás da informação e de gente que está na correria e talvez não possa te dar a informação.... você não tem um treinamento para trabalhar. Mas a insegurança foi... por não ter um treinamento no caso, não ter o conhecimento devido para exercer a atividade."

Estas novas exigências do trabalho têm-se mostrado como potenciais causadores de estresse, fadiga, sofrimento mental. Estas pessoas estão no banco anteriormente às modificações ocorridas no mercado financeiro, época em que as tarefas eram outras. Havia a valorização do trabalho do caixa, por exemplo, ou ainda os trabalhadores ficavam na agência esperando pelos clientes. Atualmente são os bancários que vão em busca de clientes, isto é uma grande mudança, é um novo paradigma que tomou conta do trabalho bancário.

Conforme expôs Izumi (1997), com vistas a seguir a nova tecnologia houve uma redução nos postos de trabalho convencionais e passou-se a solicitar dos bancários requisitos funcionais voltados para a venda de produtos e à execução de novos serviços financeiros. E no banco estudado também existe essa necessidade, pois o lado comercial está voltado para a captação de negócios e clientes de forma agressiva, objetivando acompanhar o mercado financeiro. $E$ isto é cobrado de todos os empregados da empresa. 
Para estas pessoas que estão retornando ao trabalho, algumas dificuldades se impõem no encalço do atingimento das metas: o incômodo da presença da dor, a falta de conhecimento técnico, a falta de treinamento para vendas. Uma preocupação que não é somente dos sujeitos deste estudo, mas dos empregados do banco como um todo é que a maioria do público do banco vai em busca do atendimento dos programas sociais e por isso mesmo não são clientes em potencial para vendas, pois estão desempregados ou são muito empobrecidos financeiramente. Um dos depoimentos feitos por um sujeito e anteriormente abordado expõe esta questão:

"E tem gente que fica empurrando seguro.... Ah! Sabe eu não tenho coragem. Eu, mesmo com pressão, eu não tenho coragem de fazer isso, nem ofereço....."

"E o gerente falava: Ah! Ele vende errado, mas ele vende! Então para mim você é pior que ele, porque você não vende.... eu vendia também, mas em menor quantidade.... ele achava que você não usava todos os meios e eu não achava isso, eu nunca enganei um cliente meu com produto .... eu cumpro minhas metas, mas tudo com honestidade, se eu sentir que não dá para isso.... é até, sei lá.... uma questão ética, moral."

Existe um conflito de valores em que há um desequilíbrio entre o que é exigido pelo exercício das atividades diárias e os princípios pessoais, porque freqüentemente os trabalhadores tem que oferecer produtos a quem não tem dinheiro para consumi-los.

Com relação aos fatores psicossociais foram apresentados como dificultadores a gestão de pessoas e as expectativas profissionais em relação às seqüelas físicas.

Quanto à gestão de pessoas, existe uma cobrança muito grande sobre o rendimento e desempenho individual, no sentido do cumprimento das metas estabelecidas pela empresa, como no depoimento a seguir:

"Então para mim foi dificil este retorno... hoje na minha agência tem meta individual porque tem relatório que vai para o gerente dizendo cada empregado o que ele fez....... um dia que você fica sem fazer nada é um dia que você vai embora estressada....." 
A literatura aborda a questão da gestão de pessoas de maneiras diferenciadas. Para Weber (1947) a dominação pode ocorrer de forma variada e surge quando uma ou mais pessoas obrigam outras pessoas a fazerem coisas através de ameaça ou força. Porém, afirma o autor, a dominação pode ocorrer de um jeito menos forçado, quando o indivíduo dita normas e regras e as pessoas permitem que isso aconteça, pois o enxergam com este poder. Dessa forma a dominação é legitimada e socialmente aceita, ou seja, há o reconhecimento de que aquela pessoa tem a autoridade de comando sobre o grupo, de acordo com o depoimento:

"Agora a gerente que está lá, que mudou de novo, ela não se afina muito comigo... esse relacionamento com o gerente é uma coisa que eu preciso amadurecer... então talvez seja este o único medo que ficou, que restou, sabe, que eu não consiga ter esse jogo de cintura diante da pressão... e eu aqui me arrastando com dor, meu filho me esperando, a fila enorme e você indo no cabeleireiro no meio do expediente, não dá meu! Ela também não é a única que faz isso. Se você quiser falar com ela tem que atravessar a rua e ir lá no salão...esse tipo de coisa que eu acho errado mesmo...."

Morgan (1996) mencionou uma dicotomia existente nas sociedades democráticas: o trabalhador, como cidadão é conclamado a exercer sua livre iniciativa, porém na empresa ele é impedido de tomar suas próprias decisões, colocado sob o domínio dos chefes. $\mathrm{O}$ autor usando uma metáfora em que compara a organização como um sistema político, propõe que tudo o que acontece na organização é baseado em interesses e o estilo de liderança está voltado para o seu atingimento. E desse modo o "poder final repousa sobre aqueles que sejam capazes de definir o cenário da ação." (Morgan, 1996, pg. 203), como colocado:

“Essa gerente atual ela é muito irônica, é uma coisa assim, ela faz as coisas, movimenta as coisas num momento que estava muito tumultuado, ela pôs mais lenha na fogueira e saiu de férias. Então ela mudou as pessoas, deixou um monte de gente que não sabia nada para trabalhar com as filas, né. Mas ali não dá dinheiro! A gente não faz as 
coisas só por que dá dinheiro. Então nesse momento aí a gerente mudou tudo e ninguém sabia nada, eu fiquei muito sobrecarregada, porque eu sabia um pouco mais ali..."

"E eu acabo ficando dividida, porque eu sei que tem alguém me esperando, ao mesmo tempo tem a fila, meus colegas que não sabem direito, o gerente precisa almoçar... é assim esse tumulto essa má vontade de atender o pobre, sabe.... isso me consome.... é uma pressão."

Portanto, a ideologia gerencial está apoiada na racionalidade econômica, na busca do alcance dos interesses financeiros e na otimização dos recursos para este fim. Sennett (1999) fez um reflexão sobre as possibilidades mais atuais de liderança, especialmente nas estruturas organizacionais horizontalizadas, onde o chefe se torna o facilitador da equipe. Desse modo existe o poder, mas não a autoridade e isso "permite aos líderes de uma equipe dominar os empregados negando legitimidade as suas necessidades e desejos." (pg. 137). $\mathrm{O}$ que acontece é que a ausência de autoridade permite à organização mudar, trocar, reorganizar sem ter que dar justificativas dos atos, e neste caso a mudança se torna o fator responsável e não uma pessoa.

$\mathrm{O}$ outro aspecto abordado pelos sujeitos tem relação com as expectativas profissionais e as seqüelas físicas deixadas pela doença como no depoimento a seguir:

"Então eu acho que a reabilitação não existe, pelo menos no banco, eu acho que em banco nenhum... quer dizer você acaba conversando com pessoas de outros lugares. Então em banco não existe reabilitação, porque você acaba voltando, não tem o que fazer num banco, pela natureza do trabalho... tudo acaba envolvendo alguma coisa que você não pode fazer...."

Este depoimento parece refletir o sentimento de incapacidade para exercer atividades bancárias por causa das limitações físicas. Porém também remete a um sentimento de incapacidade para qualquer outra atividade, o que pode estar relacionado com o fato de o bancário, após algum tempo de trabalho, se identificar com um especialista 
sem especialidade porque ele tem capacidades e conhecimentos muitos específicos, que na maioria das vezes só podem ser usados em estruturas de trabalho bancário.

Uma outra análise que pode ser feita a respeito deste sentimento expressado pelos sujeitos é que na maioria das vezes o serviço bancário foi uma opção involuntária do trabalhador, ou seja, este tipo de atividade muitas vezes é exercido por pessoas como forma de sustento próprio, e o trabalho em banco se torna o possível para a sobrevivência pessoal dentro do capitalismo.

Lima (1998) em estudo com bancários portadores e não portadores de LER também observou esta condição, muitos deles consideravam o trabalho bancário como uma situação provisória, uma necessidade a ser enfrentada, mesmo reconhecendo a dificuldade em abandoná-la atualmente. No seu estudo, a autora pôde constatar que muitos dos sujeitos de sua pesquisa eram de classes sociais inferiores, apresentando dificuldades financeiras e entenderam que o banco poderia proporcionar um salário razoável e a possibilidade de conciliar a jornada de trabalho com seus estudos.

Sennett (1999) fez um comentário a respeito desta sobrevivência que pede que o desejo de satisfação e realização pessoal seja adiado de modo que a história de vida seja moldada até que se tenha conseguido alguma coisa e, só então, quem sabe no futuro haja a tão esperada realização. Continuando sua reflexão o autor coloca que para se sentir humano é preciso que haja confiança e que se tenha o sentimento de ser necessário aos outros, mas neste cenário capitalista fica a questão "Quem precisa de mim?". E acrescenta-se no caso dos sujeitos dessa pesquisa: "Quem precisa do meu trabalho?"

O último fator abordado pelos sujeitos e que merece menção por pertencer ao contexto social vigente, foram as dificuldades com as instituições que lidam com a reabilitação, quais sejam: INSS, empresa e assistência médica.

O INSS que deveria colaborar no sentido da recuperação do trabalhador, acaba tornando-se um fator estressor. Apesar de ter o papel de análise da situação de saúde do 
trabalhador, se tornou apenas o auditor, trazendo tensão a seus beneficiários, que não sabem qual será o comportamento do médico do INSS durante a perícia. $\mathrm{O}$ médico perito avalia a capacidade laborativa do trabalhador afastado de suas atividades através de relatórios dos profissionais assistentes, que são os responsáveis pelo tratamento; normalmente não faz exames clínicos e praticamente nunca solicita exames complementares para a sua decisão.

Um outro dado importante é a respeito da reabilitação oferecida pelo INSS que cada vez mais está sendo desarticulada, numa tentativa de deixar este papel somente para as empresas, o que pode ser notado neste depoimento:

"Então... o pessoal do CRP me chamou lá e disseram que fecharam lá e acharam que eu poderia voltar. A moça lá falou um monte de coisas.... você tem que voltar, tem que trabalhar e agüentar a sua dor!"

Maeno (2001) em seu estudo identificou esse aspecto abordado pelos sujeitos, apontando a falha tanto do aparato estatal no que diz respeito à prevenção dos agravos à saúde do trabalhador, quanto a falta de uma política de reabilitação profissional por parte das empresas, ficando para o trabalhador o ônus da reabilitação, não só para o trabalho, como também para a vida.

Os sujeitos apresentaram uma visão a respeito do papel da empresa na reabilitação profissional:

"Então eu acho que tem tudo isso, né, que às vezes eu acho que a empresa não está preparada assim para receber... fica no individual de cada gerente, de cada unidade estar recebendo, aceitando o empregado, até assim dar para ele atividades que ele possa estar desenvolvendo."

“Agora se eu começar a falar: Ah! Isso eu não vou fazer porque tenho LER... ninguém vai me querer. $E$ eu não tiro a razão... precisa alguém assim, porque tem meta para cumprir. Eu também não iria querer perder minha função, se eu fosse gerente, sabe. 
Porque eu vou defender um funcionário que tem problema. Quem vai querer saber disso? Ninguém quer saber disso... só a gente mesmo que pensa, né."

O que ficou explicitado nos discursos é que a empresa não está organizada para receber os empregados que se encontram em processo de reabilitação profissional. Os trabalhadores que passaram por esta fase, vivenciaram no seu cotidiano situações que permitiram chegar a esta idéia. Começando pelos gerentes que não estão preparados para assumir esta responsabilidade de receber um trabalhador nestas condições. $O$ gerente tem a intenção de auxiliar, mas ele está sendo cobrado pela produção na sua unidade, como se todos os empregados ali estivessem nas mesmas condições de saúde, ou seja, não existe um diferencial na cobrança do atingimento de metas porque a unidade tem na sua lotação empregados em processo de reabilitação. Ao lado deste fator, no cotidiano o próprio gerente esquece que existem trabalhadores com limitações fisicas que não podem exercer qualquer atividade.

O terceiro fator dentro dos dificultadores com instituições apontado pelos sujeitos foi a assistência médica e o tratamento, que para alguns não foi satisfatório, ou mesmo exaustivo, como no caso do seguinte discurso:

"Agora o que me atrapalhou mesmo bastante foi o tratamento errado que eu fiz, né. E tinha o agravamento que foi uma piora e que... na verdade era o perito do INSS que iria analisar se era uma piora... ficou constatada a piora... e eu caí e quebrei a mão... só que na verdade o meu médico não considerou essa queixa ... e engessou minha mão por causa do dedão e esse ossinho aqui colou em cima do tendão. E dai teve que tirar, ai cortou o tendão e ligou de novo... agora a questão é que o tendão está preso aqui na cicatriz."

"Então a dor foi crescendo e agora ela chegou assim, se instalou e ficou, né... então eu estou fazendo uma manutenção do tratamento, mas é complicado. Você fica naquela sua rotina... com horários, prazos, compromissos... você tem sua vida em casa... tem que estar conciliando as coisas, né... e isso me pega muito assim, né, excesso de coisas a cumprir...mas tenho que estar fazendo tratamento mesmo, né. “ 
No acompanhamento das pessoas no PRT este é um comentário muito comum de ser ouvido. Apesar dos visíveis esforços dos profissionais assistentes na busca de uma melhora do quadro, bem como da qualidade de vida dos portadores de LER, muitas vezes pode-se perceber descrença e desmotivação em torno do tratamento. Normalmente as pessoas procuram tratamento quando o quadro já está bastante desenvolvido, tornando-se dificil uma evolução positiva do quadro geral.

As pessoas acompanhadas no PRT comparam o comparecimento ao tratamento, com o comparecimento ao trabalho, em muitos casos ele acaba se tornando uma rotina diária e pesada, pois os resultados são poucos e lentos. Quando as pessoas retornam ao trabalho, época em que o tratamento não poderia ser interrompido, o tempo se torna escasso e, entre o trabalho e o tratamento, elas optam pelo trabalho, especialmente para não terem que dar explicações de saídas antecipadas ou atrasos no horário de entrada.

Os profissionais do PRT costumam dar ênfase na necessidade da continuidade do tratamento, especialmente no retorno, deixando isto claro para os gerentes, porém no dia-adia percebe-se o abandono por vários motivos, como por exemplo a dificuldade de se adequar horários com os profissionais assistentes. Nesses casos seria necessária a compreensão de todas as partes quanto à importância da continuidade do tratamento.

\subsection{Aspectos contributivos para o retorno ao trabalho}

Apesar de terem sido identificados muitos fatores dificultadores, os entrevistados também apresentaram aspectos que contribuíram para o retorno ao trabalho, quais sejam: inclusão social; possibilidade de escolha do local de trabalho; mudança de comportamento; apoio social; participação em grupo de apoio.

O primeiro e mais destacado dos facilitadores, considerado pelos sujeitos como motivador foi $o$ fato de estarem trabalhando novamente e sentindo-se socialmente reconhecidos, conforme o seguinte depoimento: 
"Assim, o fato de você ficar muito tempo parada vai te dando uma sensação de inutilidade. Então foi importante estar retornado ao trabalho para se sentir útil e mostrar que você é capaz."

"E aprendi muito antes eu achava que eu era uma pessoa inútil, eu não mexia no micro e,achava que eu nunca iria aprender. Hoje eu sei o quanto meu trabalho é útil para as pessoas. E eu volto a me considerar uma boa profissional, acho que sou competente."

"E eu sempre trabalhei $e$ você fica meio excluída socialmente, você perde o referencial, então eu queria retornar ao trabalho."

Por estes depoimentos nota-se que o trabalho traz um sentimento de inclusão social, utilidade e capacidade. $O$ trabalho sendo uma das principais atividades humanas vem sofrendo modificações durante o tempo .

Keyser et al (1998) encontraram 50 definições diferentes para o significado do trabalho, em várias disciplinas. As ciências sociais, por exemplo definem a atividade de trabalho como: esforço físico ou intelectual; meta orientada dentro de um contexto de temporalidade espacial para atingir uma tarefa; integração dentro do contexto social; geração de renda; produção de bens ou serviços em troca de salário; influência de normas sociais; troca no mercado de trabalho sob condições de exploração. (pg.6)

Kaplan e Tansky (1974) realizaram uma pesquisa em alguns países sobre o significado do trabalho para as pessoas e algumas das respostas foram: dá status e prestígio; provê a renda necessária ; mantém ocupado; provê contatos sociais interessantes; é um caminho para servir a sociedade; é intrinsicamente interessante e satisfatório.

O trabalho assume uma posição central na vida das pessoas que passam a juventude se preparando para assumir uma profissão e quando adultos dispensam pelo menos dois terços de seu dia em atividades relacionadas ao trabalho. Ele determina a estrutura temporal do funcionamento da sociedade, estabelece a divisão entre produção e reprodução e traz legitimidade social ao indivíduo. 
Como afirmaram Keyser et al (1998) o trabalho é uma necessidade existencial para a maioria das pessoas, porque além de produzir o necessário para a subsistência nas questões materiais, traz satisfação pessoal e nível de reconhecimento e prestígio social, tornando-se um fator contribuinte para a auto confiança e identidade pessoal.

O outro fator considerado importante foi o reconhecimento por parte dos sujeitos da importância da possibilidade de escolha do local de trabalho e do aprendizado de novas tarefas que permitiram a aquisição de novos conhecimentos contribuindo para que o retorno às atividades fosse positivo.

Neste sentido é importante a análise feita por Hackman e Oldham (1976) que estabeleceram um modelo em que são três as características que dão sentido ao trabalho, quais sejam: variedade das tarefas, que significa o quanto o trabalho é capaz de exigir variedade de habilidades e competências do trabalhador; identidade do trabalho, diz respeito a capacidade daquele trabalho permitir a realização de uma tarefa completa, cujo resultado seja possível de ser alcançado e percebido pelo trabalhador; e significado do trabalho, característica que está relacionada com a possibilidade de o trabalho realizado ter uma repercussão positiva sobre o bem estar ou ainda sobre o trabalho de outras pessoas. Além disso são importantes a autonomia e o feedback ou seja as informações que são dadas ao trabalhador a respeito de seu desempenho.

$\mathrm{Na}$ pesquisa realizada por Morin (2001) entre estudantes, administradores canadenses e administradores franceses, chegou-se às seguintes características de um trabalho que tem um sentido quando: é feito de maneira eficiente e leva a alguma coisa; é moralmente aceitável; é fonte de experiências de relações humanas satisfatórias; garante a segurança e a autonomia; é um trabalho que mantém ocupado; permite encontrar pessoas e ter contatos francos e honestos. 
Portanto existe uma dimensão do trabalho que traz satisfação ao homem em poder ser útil e reconhecido por isto, aumentando sua auto-estima e possibilitando a afirmação de sua identidade pessoal.

Com relação à identidade é importante ressaltar alguns pontos, tendo em vista tratarse de aspecto importante para a análise da reabilitação profissional.

Ciampa (1990) realizou uma abordagem sobre o conceito de identidade assumindo várias formas. Inicialmente pode ser considerada como um traço do ser humano com caráter de metamorfose, sob a forma de personagem que vai desempenhando vários papéis durante a vida. Esta personagem, entre os diferentes papéis que excerce, aparece em um dado momento desenvolvendo uma atividade perante a sociedade e, como tal, se apresenta em relação a outros personagens. Para o autor a identidade é uma articulação entre personagens, igualdades e diferenças, envolvidas por uma história pessoal. "Identidade é história." (pg. 157)

Seligman Silva (1994) colocou que "o conceito de identidade apresenta um valor especial ao incluir a instância subjetiva, que elabora, de modo contínuo, respostas à estrutura do sistema social." (pg. 118) Acrescentou que se a identidade é abalada, a saúde psicossocial também o será. Ressalta a noção de identidade em processo que permite o entendimento das mudanças que ocorrem na identidade permeadas pelas experiências profissionais.

Assim essas mudanças sendo positivas podem contribuir no enriquecimento da identidade, com resultados benéficos para a saúde. Porém se foram mudanças negativas, pode ocorrer um empobrecimento da personalidade, significando uma perda considerável no desenvolvimento do ser humano.

Com estes entendimentos pode-se perceber a importância da identidade para a reabilitação profissional, não só no sentido abordado anteriormente como espaço territorial, como também no estabelecimento de uma nova relação com o trabalho. Este aspecto tem 
envolvido todo o discurso apresentado pelos sujeitos, na medida em que havia uma identidade anterior ao afastamento que necessariamente deverá ser alterada, não só pelas restrições fisicas que foram estabelecidas, como também por toda a carga de sentimentos (medo, insegurança) que acompanha o retorno ao trabalho.

A mudança de comportamento depois da doença foi abordada como importante, facilitando o retorno, como neste depoimento:

“Porque assim, uma das coisas que essa licença valeu é que o banco vai continuar sendo o que ele é, independente de eu chegar em algum lugar ou não, eu posso ser o que eu quiser.... eu aprendi isso... olhar o outro, me colocar no lugar dele... aumentar a minha compreensão.... Tudo que eu passei no retorno acho que foi muito bom, porque eu vi né, as coisas que estavam certas e as coisas que estavam erradas..."

A este respeito Magalhães (1998) em seu estudo fez uma abordagem sobre a doença como oportunidade de crescimento pessoal. A autora apresenta depoimentos de pessoas que aprenderam com a doença que tiveram e, em sua análise, apesar da "consciência de uma tragédia pessoal" (pg. 121) a doença aparece como uma possibilidade de redenção ou caminho para um lugar melhor na sociedade. Desta forma, as mudanças individuais importantes como a capacidade de impor limites, o reconhecimento do corpo, entre outras são assimiladas com maior tranqüilidade. Esta condição, de acordo com a autora, que utilizou-se da análise de Sontag (1989), é possível porque as pessoas portadoras de LER metaforicamente associam a doença a uma redenção e, a partir de então, elas estão perdoadas e podem se permitir limites e negações em seu comportamento pessoal.

O outro aspecto abordado pelos sujeitos como positivo para o retorno ao trabalho foi a acolhida recebida por alguns colegas:

"Porque assim, o mais legal foi a acolhida, né, eu fui muito bem recebida. Olha eu tenho muitos colegas dentro do banco, então é muito agradável você conviver com alguém que você gosta... eu estou me sentindo fazendo parte de novo.... então é um 
relacionamento bom, a gente trabalha em equipe, tenta passar isso, a gente é uma equipe $e$ um ajuda o outro.... essa acolhida que eu tive lá, foi determinante mesmo para eu continuar. "

Este aspecto também foi comentado tanto pelos participantes do grupo de atenção, quanto pelos seus colegas, na pesquisa realizada anteriormente ao retorno. Quando perguntados sobre em que poderiam contribuir com os colegas que estavam no processo de reabilitação, a maioria informou que seria receber bem e acolher estes colegas. Esta solidariedade foi um fator fundamental para a reabilitação profissional.

Seligman Silva (1987) apresentou as relações humanas dentro da empresa como fator potencial para o surgimento de tensões emocionais, especialmente quando exigem o auto-controle. Em seu estudo as pessoas apresentaram nessa dimensão, o maior número de queixas como mágoas, depressão, sentimentos de injustiça, entre outros.

Lima (1998) em seu estudo destacou a importância do relacionamento entre colegas para a saúde mental do trabalhador. A autora em sua pesquisa ofereceu o depoimento de bancários que apontam os atritos entre colegas como um fator de estresse no trabalho. A situação contrária, ou seja, de boas relações interpessoais no ambiente de trabalho pode ser considerada como um aspecto promotor de saúde.

O outro aspecto abordado como positivo para o retorno foi mencionado pelos participantes do Grupo de Atenção:

"E uma coisa que ficou para mim como muito bom foi ter participado do processo todo de reabilitação. Era uma coisa que eu estava bastante resistente, eu não estava assim aceitando a idéia com facilidade. E com o decorrer dos encontros eu fui sentindo que aquilo me ajudava. E (ajudou) eu acho que o PRT, aqueles encontros grupais. Porque assim, é lógico a gente sabe que não é o único na vida que tem problema, mas o fato de você estar com um grupo que também vai começar junto, né... eu acho que isso ajuda...." 
As atividades com grupos têm sido utilizadas no campo da saúde do trabalhador. Sato et al (1993) divulgaram a sua experiência no desenvolvimento de grupos com portadores de LER, em que são feitas reflexões sobre as possibilidades de melhoria da qualidade de vida dessas pessoas, através da discussão sobre os aspectos que envolvem a doença, especialmente os psicossociais.

Siqueira e Queiroz (2001) abordaram em seu artigo a possibilidade de se atuar com enfoque preventivo e abordagem grupal na saúde do trabalhador, relatam a atuação com grupos de portadores de LER. Afirmaram que esta prática tem possibilitado ao trabalhador refletir sobre os vários aspectos que envolvem a doença e que este tem sido um caminho eficaz na diminuição de sintomas, na minimização do sofrimento psíquico, no entendimento de questões legais e dos fatores de risco presentes nos processos de trabalho.

Glina et al (2004) expuseram o trabalho desenvolvido com grupos na área de saúde do trabalhador, em que o principal objetivo era o de fornecer condições ao trabalhador para desenvolver habilidades possíveis dentro de suas condições atuais para o retorno ao trabalho, estabelecendo uma rede de parcerias para o encaminhamento dessas pessoas. Os resultados apontam que esta iniciativa pode ser apenas um primeiro passo, mas com certeza ele foi dado na direção correta.

No presente estudo os depoimentos tanto dos participantes do Grupo de Atenção, quanto dos sujeitos consideraram a experiência da atividade grupal como positiva. Este tipo de abordagem contribuiu para a diminuição do nível de ansiedade e sentimentos negativos associados à reabilitação profissional, na medida em que os participantes receberam apoio e não se perceberam solitários no processo de retorno ao trabalho.

\subsection{A vivência da LER}

É importante se fazer uma discussão sobre as LER porque este estudo esteve voltado para a reabilitação de bancários portadores de LER. O discurso dos sujeitos 
demonstrou que o adoecimento por LER é uma vivência difícil de ser esquecida, mesmo depois do retorno ao trabalho e de ele ter sido um sucesso.

Também existem algumas considerações a serem feitas a respeito das LER, porque devem estar presentes quando forem desenvolvidas ações de reabilitação profissional com trabalhadores portadores desta síndrome. A reabilitação profissional oficial sempre esteve voltada para os trabalhadores com amputações e outras seqüelas diferentes das apresentadas pelos portadores de LER. Por isso devem estar claras as dificuldades apresentadas por estes trabalhadores para que o processo de retorno ao trabalho seja efetivo.

A princípio julgou-se importante uma breve análise a respeito dos dados demográficos, tanto dos sujeitos da pesquisa, quanto da população geral do PRT, a grande maioria é composta por mulheres. Esta estatística acompanha órgãos oficiais, como por exemplo a apresentada pelo Programa de Saúde do Trabalhador do Mandaqui entre os anos de 1987 a 1991, em que 84\% dos atendidos eram mulheres, ou pelo NUSAT - Núcleo de Saúde dos Trabalhadores de Belo Horizonte, em que nos anos de 1987 e 1989 havia a predominância de mulheres no serviço ( $71 \%$ e $76 \%$ respectivamente).

Ribeiro (1997) em sua pesquisa também informou sobre a predominância das mulheres, dos 1223 casos conhecidos de LER no banco pesquisado, 79\% eram mulheres e na amostra da pesquisa, este percentual subiu para $83 \%$.

Algumas observações foram feitas em estudos, como por exemplo o de Barnard (1982) sobre as possibilidades dessas afecções alcançarem mais o público feminino: as mulheres foram mais contratadas do que os homens para realizar tarefas que exijam coordenação motora fina e habilidades manuais; suas estruturas musculares são menos fibrosas, tendendo a ter menos energia para o exercício de tarefas no trabalho; ossos mais leves e curtos; interferência dos hormônios; além é claro das exigências da vida doméstica, pois culturalmente lhes são atribuídas as tarefas de assistência aos familiares, bem como as tarefas domésticas, estabelecendo-se assim uma segunda (às vezes terceira) jornada de trabalho. 
Segnini (1998) fez uma reflexão sobre a feminização do trabalho bancário, dando como exemplo a função de caixa, que neste estudo representa $60 \%$ da população total do Programa e $71 \%$ dos sujeitos da pesquisa. A autora a princípio explicou que o exercício da função do caixa se deu através de duas tarefas: a primeira foi a entrada de dados de acordo com normas pré-estabelecidas, que foi considerada como de baixa necessidade de qualificação, pois não demandavam tomada de decisão, e sim concentração e responsabilidade; a outra tarefa foi a de atendimento ao cliente e culturalmente acredita-se que as mulheres possuíam as características necessárias para esta atividade, ou seja, a beleza, a paciência, a gentileza. Além disso, ressaltou a autora que as mulheres ocuparam essas funções também devido a sua carga horária permitir o desempenho dos outros papéis delas solicitados.

No contexto da acumulação flexível a organização do trabalho bancário conseguiu dessa forma diminuir e até mesmo eliminar conflitos pessoais por conta das mulheres não conseguirem alcançar postos mais elevados na administração. Porém, sendo o caixa, o segmento mais afetado pelas LER no banco, as mulheres acabaram sendo as mais atingidas em sua saúde e também nas relações de trabalho.

Um outro dado importante foi a questão da faixa etária em que se encontra a maioria da população pesquisada, que estava entre 41 a 45 anos. As pessoas ainda estavam em idade produtiva ou seja, se percebem com plena capacidade para o trabalho e ter limitações de movimentos incomoda e traz sentimentos de angústia e depressão. Esta situação foi agravada pelo medo da demissão, pois o mercado de trabalho, em poucas exceções, não admite pessoas nesta faixa etária, que são consideradas velhas, reduzindo-se a chance de um novo emprego.

Além disso alguns estudos como o da Organização Mundial da Saúde (1985) indicaram que o envelhecimento traz um decréscimo na habilidade de se adaptar aos desafios ambientais. Foram citados dois fenômenos que ocorrem no organismo: primeiro a sua deterioração e, em segundo, há um processo que compreende muitas adaptações e 
mecanismos de regulação na tentativa de preservação da vida. E assim fatores ocupacionais como pressão do tempo, mudanças tecnológicas, ritmo acelerado, trabalho fragmentado, alto nivel de vigilância e condições desfavoráveis de trabalho podem aumentar as dificuldades de adaptação do organismo ao meio ambiente, trazendo conseqüências físicas e mentais mais marcantes por causa do envelhecimento.

Quanto à função exercida pela população da presente pesquisa, foi bastante semelhante ao estudo de Ribeiro (1997) em que 95\% dos adoecidos encontravam-se na faixa hierárquica inferior do banco e a quase totalidade eram caixas. Aqui também a grande maioria de homens e mulheres eram caixas, sendo esta uma função considerada como de risco para LER. O tempo de trabalho no banco não interferiu no adoecimento, e a média de afastamento do trabalho ficou em 3 anos.

Um outro dado apresentado foi quanto ao grau de instrução, em que a maioria das pessoas possuíam nível superior e muitas vezes a formação acadêmica não era compatível com a atividade bancária. Existiam muitos psicólogos, assistentes sociais, pedagogos, comunicadores sociais, etc, fato que pode trazer uma certa frustração por não conseguir atuar dentro da sua escolha profissional.

Este assunto foi abordado anteriormente quando se comentou a respeito da maioria dos trabalhadores bancários pertencerem a classes mais inferiores e almejarem a conciliação do trabalho e dos estudos. Lima (1998) em seu estudo detectou que a maioria de seus entrevistados tinha como única opção o trabalho bancário, considerando a necessidade de sobrevivência financeira. A autora ainda constatou que após grande esforço por parte dos trabalhadores, muitos conseguem terminar o curso universitário, aumentado assim ainda mais a defasagem existente entre a competência adquirida e aquelas que eram exigidas na execução das tarefas no banco, trazendo sentimentos de frustração e desânimo.

Apesar de não terem sido questionados quanto às razões de seu adoecimento, os sujeitos da pesquisa discursaram sobre este assunto, apresentando as seguintes: a falta de 
informações e de uma ação preventiva por parte da empresa; o ambiente físico, o mobiliário e as tarefas inadequadas; gestão inadequada e características pessoais.

A primeira referência existente sobre as LER foi a publicação feita por Ramazzini em 1700, escrevendo sobre o que ele chamou de Doenças dos Escribas e Notários, cujos sintomas eram extremamente semelhantes aos descritos atualmente como características das LER. Porém foi somente com o incremento da tecnologia que se intensificou o aparecimento dos casos de LER.

A automação e a tecnologia, apesar de trazerem consigo a diminuição do trabalho físico, não diminuiu aquilo que foi chamado por Marx (1959) de trabalho vivo, pelo contrário, mesmo com o uso das máquinas a quantidade de horas trabalhadas não diminuiu. O que ocorreu foi a diminuição do gasto energético, fazendo com que esse esforço seja de outra natureza, o esforço agora é leve, permitindo agilidade no uso das estruturas músculoesqueléticas dos membros superiores.

Entre os vários estudos mencionados na introdução desta pesquisa, destaca-se o de Ribeiro (1997) que escreveu um artigo baseado em uma pesquisa feita entre bancários. Ele abordou essa questão da crescente progressão das LER na década de 80 e que tornou-se nos anos 90 uma das doenças do trabalho mais notificadas junto ao INSS. Em seu artigo, o autor fez uma indagação sobre como explicar a falta de ações por parte da direção das empresas em torno desse tema. E apresentou o depoimento de um dos sujeitos da sua pesquisa que fala sobre a ignorância da administração do banco, acreditando mesmo nesse desconhecimento do tema e de sua gravidade. Porém o autor afirmou que as empresas aperfeiçoaram seus sistemas de controle de informações, não sendo portanto totalmente inocentes com relação ao desconhecimento do assunto, a hipótese foi de um distanciamento entre a direção da empresa e a realidade vivenciada pelos adoecidos.

Da mesma forma, na visão dos sujeitos, no banco pesquisado ocorreu esse distanciamento, as políticas criadas estavam na maioria das vezes voltadas mais para a produtividade, sem que houvesse a participação do trabalhador na sua elaboração: 
"Antes de eu me afastar, eu tive amigas que haviam desenvolvido LER e o que a gente via era uma folha com uns desenhos de ginástica que a gente tinha que fazer.... mas isso era muito precário...."

Ou ainda quando mencionaram o novo mobiliário:

"E quando tinha aqueles móveis antigos... eu sentia dor, mas a partir do momento que mudou, com esses móveis agora, ai eu piorei. Eu sentia muito mais dor nas costas, nossa muito mais."

Uma outra razão apontada pelos sujeitos para o surgimento das LER são as características pessoais tais como agitação, aceleração, rapidez, ordem excessiva, querer fazer todas as tarefas que aparecem, não se organizar para realizar as pausas.

Quanto à relação entre LER e os fatores psicossociais o NIOSH (1997) realizou uma revisão bibliográfica das principais pesquisas feitas neste sentido, em nível internacional. Eles informaram sobre o aumento das evidências de que os fatores psicossociais tinham papel importante no desenvolvimento dos distúrbios osteomusculares. Apesar das dificuldades encontradas em relação às medidas utilizadas pelos pesquisadores, pois as mesmas não estavam padronizadas nem eram tão objetivas quanto as medidas físicas, existia uma evidência desta associação, e isso em diversas ocupações.

No documento, os autores apresentaram três domínios dos fatores psicossociais, quais sejam: fatores associados ao trabalho e ao ambiente de trabalho; os associados com o ambiente extralaboral e as características individuais. Quanto aos fatores associados ao ambiente extralaboral e às características individuais, os estudos não demonstraram consistência e, por este motivo foram avaliados somente os fatores relacionados ao trabalho e ao ambiente de trabalho.

Por outro lado a publicação da OMS (1987) apresentou um capítulo sobre diferenças individuais na suscetibilidade ao estresse. Nesse estudo foi abordada a questão 
da mensuração do estresse envolvendo a avaliação das dificuldades e facilidades da vida diária. Como exemplo de dificuldades foram citados o engarrafamento ou ainda as más condições do transporte público, em contrapartida uma das facilidades seria ter uma boa noite de sono. Chamou-se a atenção para o fato de que era necessário contrapor este tipo de avaliação à estrutura sociológica ou antropológica, pois as sociedades encaram essas facilidades e dificuldades de maneira diferenciada, podendo haver maior ou menor significância dentro do referencial que cada cultura traz consigo.

Esse fato também ocorreu em relação às diferenças individuais, pois da mesma forma deve se considerar os estilos de vida e personalidade de cada pessoa. Foi introduzido o conceito de suscetibilidade ou vulnerabilidade ao estresse, referindo-se a uma tendência particular de conseguir ou não arcar com as situações difíceis que surgem e seu significado psicológico sendo dependente das condições de vida da pessoa. Então uma pessoa pode estar mais ou menos suscetivel ao estresse dependendo de sua relação com o ambiente. Foi informado que existem duas variações de personalidade que parecem estar mais ligadas ao conceito de suscetibilidade ao estresse que são as pessoas que possuem maior ou menor grau de confiança em suas crenças sobre si mesmo e sobre o mundo. Esta confiança tem a ver com as metas estabelecidas para si mesmas e com as escolhas que as pessoas fazem para alcançá-las. Para algumas pessoas a realização material é de extrema importância, para outras a qualidade dos relacionamentos tem prioridade. $O$ outro conceito que complementa a suscetibilidade é o da resistência, que pode ser apresentado como sendo recursos existentes que permitem ao indivíduo administrar o estresse. Estes recursos podem ser: conhecimento, habilidades, financeiros, acesso à suporte social e ambiente social.

Em outra análise, à luz da psicopatologia do trabalho, Betiol (1997) fazendo uma reflexão sobre os efeitos psíquicos do taylorismo, afirmou que o funcionamento psíquico não se coloca em repouso, como queria Taylor. A autora explicou que no trabalho taylorizado o trabalhador se vê impulsionado a lutar contra o seu próprio funcionamento psíquico, movimento que na clínica recebe o nome de repressão. Nesta situação o trabalhador busca eliminar esta tensão no modo operatório, acelerando seu ritmo de trabalho, procurando provocar um "curto circuito em seu aparelho psíquico" (pg. 19). E 
ainda se na saída, ou seja no final da jornada de trabalho ele não atingiu o seu intento, o trabalhador acaba mantendo a aceleração onde ela não é mais necessária, então ele corre mais com seu automóvel, as refeições são engolidas e as tarefas domésticas são realizadas no mesmo ritmo da máquina. Ainda, segundo a autora, isso ocorre porque esse comportamento é mais fácil do que deixar florescer as fantasias e o funcionamento psíquico para depois ter que reprimi-lo novamente.

As características pessoais foram mencionadas também no grupo de atenção como um problema para o respeito aos limites. As pessoas expuseram suas dificuldades quando observavam o ritmo de trabalho dos colegas em contraposição ao seu próprio estado de saúde. "Como dizer não?" O receio foi de que ninguém os compreenda. Esta situação foi ainda agravada pela dificuldade pessoal em aceitar as limitações impostas pela doença, como neste discurso:

"Então no dia a dia você já sabe suas limitações, né, isso é que foi a coisa pior, você aceitar que tem uma limitação é também um conflito.... além disso você mesmo não consegue entender que você tem limitações e que você tem que aprender. Às vezes esquece o lado fisico e ai as dores começam a te mostrar que você tem que ir mais devagar... mas ai a necessidade de você mostrar que você não é só braço, né, que você pode estar produzindo...."

Essa necessidade de mostrar a capacidade para o trabalho advém da subjetividade da doença expressada através da invisibilidade da dor, característica principal das LER. Com relação a este aspecto Sato et al (1993) chamaram a atenção para o fato de que existe a suspeita de que as LER têm como causa fenômenos de ordem psicológica, argumento carregado de uma conotação indevida, sendo entendido mais como se o portador fosse fraco, preguiçoso e sem vontade, ou pior, como se essa pessoa estivesse fingindo a dor, conforme indicado no depoimento: 
"..... existe todo um lado místico... o pessoal fala parece que não tem nada, né, é uma doença abstrata... assim de fora parece que não tem nada....mas só você sabe, né, no seu dia a dia o que limita ou não."

É claro que a dimensão psicológica existe como causa concorrente ao adoecimento, porém não no sentido perjorativo acima exposto, mas sim como resultado do contexto de trabalho existente dentro da lógica capitalista.

O psicológico leva a uma reflexão sobre a pessoa e suas experiências de vida. Dejours (1996) apresentou a idéia de que a "saúde das pessoas é um assunto ligado às próprias pessoas". Para ele a saúde é um objetivo a ser alcançado e o estado mental faz parte dessa busca. Ele, enquanto estudioso da psicopatologia do trabalho menciona as dificuldades vividas pelos trabalhadores e apresenta o conceito de sofrimento no trabalho: "O sofrimento é então definido como o espaço de luta entre de um lado o bem estar (para retomar aqui o termo consagrado pela definição de saúde fornecido pela OMS) e, de outro, a doença mental ou a loucura." (Dejours, 1996, pg. 153) Neste contexto, segundo o autor, atuam as defesas coletivas, as ideologias defensivas $\mathrm{e}$ as defesas individuais. A psicopatologia do trabalho coloca o sofrimento no meio da relação psíquica entre o homem e o trabalho. Explica Dejours (1996) que através de uma organização do trabalho equilibrada, que exalte a criatividade, conferindo sentido ao trabalho, reconhecimento e identidade ao trabalhador, pode se obter uma situação de trabalho que seja promotora de saúde. O problema advém das pressões da separação taylorista entre concepção e execução, isto sim faz com que o sofrimento se torne psicopatológico trazendo conseqüências sérias para a saúde do trabalhador.

Neste ponto, retomando a reflexão inicial sobre o que é psicológico dentro do desenvolvimento das LER, é notório que existe a dimensão psicológica, porém como mais um fator contributivo, sendo importante destacar o quanto o trabalho enquanto exigência mental pode colaborar no adoecimento. Portanto a singularidade individual deve fazer parte da análise das situações de trabalho, porque não se pode deixar de lado o indivíduo, sua história, sua personalidade. E no caso do presente estudo, uma dificuldade apontada pelos 
sujeitos foi a questão da dor, uma dor que não se esquece, pois ela não passa, como no depoimento:

"...Assim eu acho que a dor não vai melhorar nunca... eu estou fazendo com que essa dor faça parte do meu cotidiano, uma dor que não afete a minha vida."

A dor é uma experiência muito individual, as pessoas podem até procurar compartilhá-la com outros, mas ela é muito dificil de ser descrita.

Ferreira (1994) explicou que o corpo é visto como um signo, que através de sinais e sintomas leva a um significado, a doença. Este signo deveria ser compartilhado pelo grupo social com o qual se vive, porque isso lhe dá legitimidade, pois conforme destacou a autora "as representações que os indivíduos possuem a respeito de doença estão diretamente relacionados com os usos sociais do corpo no seu estado normal." (pg. 104)

Sontag (1984) através da análise sobre as doenças e a vida em sociedade, apresentou as metáforas com que foram designadas as doenças ao longo da história e o quanto isso influencia o doente. A doença foi vista como castigo sobrenatural, depois como merecimento e depois como expressão da vontade. A autora chamou a atenção para o significado moralista que foi dado à doença e para aquelas doenças que possuíam causas variadas e tinham maior probabilidade de serem utilizadas pela sociedade como metáforas para o que se considera social ou moralmente errado.

Esta é uma questão importante no caso das LER porque elas possuíam uma importante e complexa multiplicidade de causas e além disso a dor, que é a sua expressão mais forte, não traz a aparência necessária à pessoa para ela ser considerada como adoecida. Esta invisibilidade provoca discriminação e preconceito que foram assim expostos pelos sujeitos:

"... é uma doença abstrata... assim de fora parece que não tem nada .... mas só você sabe, né, no seu dia a dia o que limita ou não..." 
E pelo discurso dos sujeitos a não aceitação da realidade da doença expressada pela discriminação aumenta o nível de dor, chegando a ser um sofrimento moral, como neste trecho do discurso:

"Então você já é discriminado por um monte de coisas né, porque é uma doença que ninguém vê, então tem gente que não acredita que exista. Tem gente que fala Ah! Mas eu também tenho dor! Sabe, tem dor de todos os tipos. Isso você tem que explicar, é um absurdo você ter que ficar discutindo sua dor com alguém."

No discurso dos sujeitos esta temática foi abordada como um dos dificultadores de retorno ao trabalho. Na percepção dos entrevistados os colegas e chefias muitas vezes desacreditam da presença da dor e acabam desconsiderando o portador de LER como um empregado com potencialidades profissionais, como foi colocado:

"E olha o que eu acho que me atrapalhou bastante foi essa coisa do... preconceito, tá? Eu acho que o pessoal fica te achando meio.... com parte de lesionado, e eles não conseguem tratar você como um profissional que teve um problema de saúde....."

E depois de passado algum tempo os colegas e chefias acabam esquecendo que aquela pessoa retornou ao trabalho e ainda tem dor e especialmente limitações laborativas, o que foi apontado também como um dificultador:

"Ai eu voltei, só que assim, a gente volta com muitas... restrições. Só que na hora que você está trabalhando... todo mundo esquece... eles deixam de acreditar que você precisa ter alguns cuidados com a saúde... eles passam a te questionar....."

Ribeiro (1997) analisou esta situação em seu artigo afirmando que as limitações aumentam o sofrimento físico e mental dificultando ainda mais a reinserção tanto no ambiente de trabalho, quanto entre familiares e amigos. $\mathrm{O}$ fato de não poder fazer é entendido como um desejo de não trabalhar. Em sua pesquisa, assim como neste estudo, as 
pessoas já estavam em graus avançados da doença, o que denota a grande dificuldade em procurar auxílio médico, o que pode indicar falta de informações, como até foi reconhecido pelos próprios sujeitos, mas também pode significar a negação do adoecimento pelo próprio adoecido, especialmente pelas limitações que a doença traz, o que já foi anteriormente comentado.

Por tudo isto as LER se tornaram um complexo problema de saúde pública, conforme afirmou Ribeiro (1997): "...são um modo de adoecimento emblemático, revelados das contradições e da patogenicidade social desse novo ciclo de desenvolvimento e crise do modo de produção capitalista." (pg 85) 


\section{CONCLUSÕES}

Tendo em vista os resultados obtidos e na discussão feita anteriormente pode-se perceber que a reabilitação profissional, apesar de ser uma situação complexa, é possível de ser efetuada, havendo a necessidade do envolvimento efetivo das empresas, dos indivíduos, das instituições que atuam nessa área e também da sociedade.

Foram verificados dificultadores e facilitadores do processo de retorno ao trabalho. Os dificultadores apontados como principais pelos sujeitos, dizem respeito à organização do trabalho, fatores psicossociais, falta de preparo das instituições que lidam com a reabilitação profissional.

Quanto à forma de organização do trabalho, questões relacionadas com: tarefas (qualidade, densidade, natureza, conteúdo, exigências); ritmo acelerado; realização de horas extras; falta de pausas durante a jornada, além das exigências do novo perfil do trabalho bancário, muitas vezes incompatíveis com as habilidades e competências do trabalhador.

Com relação aos fatores psicossociais, foram mencionadas a gestão de pessoas que ocorre de maneira inadequada e as expectativas profissionais que ficaram frustradas. Porém o de maior relevância foi o relacionamento interpessoal, apresentado em ambos aspectos facilitador e dificultador.

As instituições que lidam com a reabilitação (INSS, empresa e assistência médica) não têm colaborado para o sucesso do processo de retorno ao trabalho.

No que diz respeito aos facilitadores, os fatores considerados como importantes foram: o sentimento de inclusão social que o trabalho traz a qualquer indivíduo; a mudança de comportamento; apoio social; participação em grupo de apoio. 
Os fatores ligados ao sucesso ou ao fracasso na reabilitação profissional estão pautados então em dois aspectos, quais sejam a organização do trabalho e o apoio social. Portanto qualquer ação que se pense no contexto do trabalho deve necessariamente contemplá-los. Desta forma, levando-se em consideração todos estes aspectos, podem ser feitas algumas recomendações, a título de sugestões de ações, no caso da reabilitação profissional entre trabalhadores com LER :

$>$ Estabelecer corretamente as restrições físicas e psicológicas específicas de cada trabalhador, procurando evitar generalizações.

$>$ Possibilitar a escolha do local de trabalho.

$>$ Identificar tarefas que permitam ao trabalhador uma identidade pessoal, autonomia e que estejam de acordo com as suas restrições, contando neste momento com a participação efetiva do trabalhador e do gerente.

$>$ Procurar adequar posto de trabalho e ambiente físico às restrições do trabalhador, além de permitir a realização de pausas, sempre que necessárias e não somente as regulamentares.

$>$ Proporcionar adequação de horários de trabalho com horários de tratamentos.

$>$ Rever a distribuição de tarefas como um todo nos locais de trabalho, não permitindo a realização de horas extras.

$>$ Estabelecer metas de produção compatíveis com as restrições físicas e psicológicas do trabalhador.

$>$ Realizar treinamento inicial e reciclagens de conhecimentos periodicamente.

$>$ Implementar um programa de comunicação interna que dissemine informações sobre as LER e sobre a reabilitação profissional.

$>$ Instituir a figura do tutor (gerente) no local de trabalho, responsável pelo acompanhamento do trabalhador que está retornando às atividades, no que diz respeito ao seu cotidiano laborativo.

$>$ Incentivar a cultura do bom relacionamento interpessoal, especialmente procurando eliminar a discriminação para com os adoecidos.

$>$ Criar mecanismos de avaliação gerencial com relação à gestão de pessoas e sua saúde e segurança no trabalho. 
$>$ Implementar o atendimento em reabilitação profissional com abordagem interdisciplinar.

Para finalizar este estudo podem ser apresentados dois discursos que foram extraídos dos depoimentos dos bancários entrevistados e que resumem os pontos dificultadores e facilitadores do processo de reabilitação:

“Então em banco não existe reabilitação, porque você acaba voltando, não tem o que fazer num banco, pela natureza do trabalho, tudo acaba envolvendo dentro de um banco alguma coisa que você não pode fazer.... Não tem muita digitação... eu acho assim é muita coisa para você dar conta.... é muito corrido, um ritmo acelerado.... tem o público lá, que está te olhando e ele cobra... e tem a pressão interna... tem que ter produção... o que importa para eles é vender, não importa se você é uma ótima operacional..... e a gerente não ajudou, como a maioria ela falava que eu não queria trabalhar... e também o medo que eu senti foi ter percebido muita mudança organizacional... e é uma agência um pouquinho dificil... porque você ia pedir ajuda para os outros e ninguém gostava de ajudar... então você não encontra pessoas preparadas para te receber....."

"Eu queria voltar... eu sinto falta do trabalho... o fato de você ficar muito tempo parada te dá uma sensação de inutilidade. Então foi importante estar retornando ao trabalho para se sentir útil e mostrar que você ainda é capaz... e ter vindo para uma área diferente, acho que a vivência é diferente, então acho que para o meu crescimento foi muito bom... e fazendo uma coisa que eu gosto de fazer, que eu sei que me dou bem....E é um relacionamento bom, a gente trabalha em equipe, tenta passar isso, a gente é uma equipe e um ajuda o outro.... E tudo que eu passei no retorno acho que foi muito bom, porque eu vi, né, as coisas que estavam certas, as coisas que estavam erradas, até assim, no meu comportamento mesmo, né... e uma coisa que ficou como muito bom foi ter participado do processo todo de reabilitação." 


\section{REFERÊNCIAS}

Aglietta M A theory of capitalist regulations. Londres, 1979. In Harvey D. A condição pós moderna: uma pesquisa sobre as origens da mudança cultural. São Paulo: Loyola; 1993.

Ahlgren C, Hammarstrom A .Has increased focus on vocational rehabilitation led to an increase in young employees'return to work after work-related disorders? Scand $\mathbf{J}$ Public Health. 1999 SEP; 27 (3):220-7.

Antunes, R. Adeus Ao Trabalho? Ensaio Sobre As Metamorfoses a Centralidade Do Mundo Do Trabalho. São Paulo: Cortez; 1995.

Annunziato F Il fordismo nella critica di Gramsci e nella realitá. Statunitense Contemporanea. Critica Marxista. Italia: 1989, n.6. In Antunes, R. Adeus Ao Trabalho? Ensaio Sobre As Metamorfoses e a Centralidade Do Mundo Do Trabalho. São Paulo: Cortez; 1995.

Barnard C et al A máquina Humana. Ed. JB, 1982. In Sato L et al. Atividade em grupo com portadores de LER e achados sobre a dimensão psicossocial. Rev. Bras. De Saúde Ocupacional. JUL/AGO/SET/1993; 79 Vol 21: 49 - 62

Bernstein R Habermas and modernity. Oxford, 1985. In Harvey D. A condição pós moderna: uma pesquisa sobre as origens da mudança cultural. São Paulo: Loyola; 1993.

Betiol MIS Quais são os efeitos psíquicos do taylorismo? São Paulo; 1997. [Resumo de aula da EASP/FGV]. 
Blass LMS. Trabalho bancário: O(re) fazer de todo instante. São Paulo: SEEB-SP; 1989. In: Instituto Nacional de Saúde no Trabalho/CBN/CUT. A Saúde no Trabalho Bancário. São Paulo: 1993.

Borges LH. O trabalho do caixa bancário, saúde mental e Lesões por Esforços Repetitivos (LER). In Glina DMR e Rocha LE (org) Saúde Mental no Trabalho, Desafios e Soluções. São Paulo: Editora VK, 2000.

Boyer M. The return of aesthetics to city planning society; 1986: n 25(4) pp. 49-56. In Harvey D. A condição pós moderna: uma pesquisa sobre as origens da mudança cultural. São Paulo: Loyola; 1993.

Brasil. Ministério da Previdência e Assistência Social. INSS Portaria 4698 de 17/08/98 dispõe sobre Norma Técnica para DORT, PAIR, benzenismo e pneumoconioses. Diário Oficial da República Federativa do Brasil. Brasília; 19 AGO 98.

Braverman H. Trabalho e capital monopolista. A degradação do trabalho no Sec. XX. Rio de Janeiro: Guanabara; 1987.

Carvalho CES et al. Tenossinovite Ocupacional: um novo conceito em processamento de dados. Parte I. Rev. Seg. Prev 1986; (18): 8- 10.

Chauí M. Convite à Filosofia. São Paulo: Editora Ática; 1995.

Chaves ME de C, Valadares C, Borges LH, Bussacos M, Lino MLMR. Organização do trabalho e saúde dos bancários - Salvador, BA. Rev. Bras. Saúde Ocupacional 1988; 25 (93/94): 39-56.

Ciampa A da C. A estória de Severino e a história de Severina - um ensaio de psicologia social. São Paulo: Brasiliense; 1990. 
Clarke S. Crise do fordismo ou crise da social democracia? Lua Nova. São Paulo: CEDEC; n. 24, 1991. In Antunes, R. Adeus Ao Trabalho? Ensaio Sobre As

Metamorfoses e a Centralidade Do Mundo Do Trabalho. São Paulo: Cortez; 1995.

Coriat B. Pensar al revés (Trabajo y organización em la empresa japonesa)

México/Espanha, siglo XXI, 1992 b. In Antunes, R. Adeus Ao Trabalho? Ensaio

Sobre As Metamorfoses e a Centralidade Do Mundo Do Trabalho. São Paulo: Cortez; 1995 .

Dejours C. Uma nova visão do sofrimento humano nas organizações. In Chanlat JF (Coordenador). $\mathrm{O}$ indivíduo na organização. Dimensões esquecidas. V1, V2 e V3. São Paulo: Atlas; 1996. $3^{\text {a }}$ Edição.

DIEESE - Anuário dos trabalhadores 1996 - 1997. São Paulo,1997.

Elders LA, van der Beek AJ, Burdorf A Returns work after sickness absence due to back disorders - a systematic review on intervention strategies. Int Arch Occup Health. 2000, JUL; 73(5): 339-48.

Ely HB Mundanças tecnológicas nos bancos brasileiros. São Paulo: SEE/SEBE; 1993.

Ferreira J O corpo sígnico . In Alves PC, Minayo, MC de S. Saúde e Doença: um olhar antropológico. Rio de Janeiro: Fiocruz; 1994.

Ferreira Junior M, Conceição GM, Saldiva PH. Work organization is significantly with upper extremities musculoskeletal disorders among employees engaged ininteractiva computer-telephone tasks of an international bank subsidiary in São Paulo, Brazil. Am J Ind Med. 1997 APR; 31 (4): 468 - 73.

Fisher G Espaço, Identidade e organização. In Chanlat JF (Coordenador). O indivíduo 
na organização. Dimensões esquecidas. V1, V2 e V3. São Paulo: Atlas; 1996.

Fleury ACC, Vargas N (Coord) Organização do Trabalho. São Paulo; Atlas; 1986.

FUNDACENTRO/CRP/INSS Caracterização dos acidentes graves de trabalho. Revista Brasileira de Saúde Ocupacional. 1990; 71(18): 32-45

Gard G, Sandberg AC Motivating and demotivating factors for return to work. Departament of musculoskeletal disorders, Division of Physical Therapy, Lund University, Box 5134, 22005 Lund, Swedeen and Departament of Physical Therapy, Karolinska Hospital, Stockholm, Sweden. In: International Ergnonomics Association. Proceedings of $13^{\text {th }}$ Triennial Congress of the International Ergonomics Association; v4; 1997; Helsinki, Finish Institute of Occupational Health.

Glina DMR; Rocha LE. Fatores de estresse no trabalho de operadores de centrais de atendimento telefônico de um banco em São Paulo. Rev. Bras. Med Trabalho V1, p 3442,2003 a.

Glina DMR, Rocha LE. Exigências do trabalho, prevalência de dor muscular e de sintomas de estresse em estagiários do setor de cobrança de um banco internacional. Rev. Ter. Ocup. Univ. São Paulo V14, n1, p 10-18, 2003 b.

Glina DMR, Felipone SMN, Rodrigues ILG, Parra ARC, Marques MNM, Yamada NF. Grupo de reorientação profissional com trabalhadores: nova proposta da saúde do trabalhador? In Lancman S. Saúde, Trabalho e Terapia Ocupacional. São Paulo: ROCA; 2004.

Guzmán J, Esmail R, Karjalainen K, Malmivaara A, Irvin E, Bombardier C.

Multidisciplinary bio-psicho-social rehabilitation foi chronic low back pain (Cochrene Review) In: The Cochrane Library, Issue 3, 2003. 
Habermas J. Modernity: an incomplete project. H foster (ed); 1983. In Harvey D A condição pós moderna: uma pesquisa sobre as origens da mudança cultural. São Paulo: Loyola; 1993.

Hackman JR, Oldham GR. Motivation through the design of work: test of a theory. Organizational Behaviour and Human Performance, v 16 p 250 - 279, 1976 in Morin EM. Os sentidos do trabalho. RAE - Revista de Adm de Empresas JUL/SET 2001; 41 n 3 p 8 - 19 .

Haro UID de Reabilitação profissional: o limiar entre a inclusão e a exclusão: uma reflexão sobre o modelo convencional de reabilitação profissional Rio de Janeiro; 1998 [Dissertação de mestrado apresentada a Escola Nacional de Saúde Pública]

Harvey D A condição pós moderna: uma pesquisa sobre as origens da mudança cultural. São Paulo: Loyola; 1993.

Hassard J Tempo de trabalho - outra dimensão esquecida nas organizações. In Chanlat JF (Coordenador). $O$ indivíduo na organização. Dimensões esquecidas. V1, V2 e V3. São Paulo: Atlas; 1996.

Helfenstein Junior, $M$. Prevalência da síndrome da fibromialgia em pacientes diagnosticados como portadores de lesões por esforços repetitivos (LER). São Paulo; 1997. [ Tese de Doutorado apresentada a Universidade Federal de São Paulo. Escola Paulista de Medicina]

Horkheimer M e Adorno T The dialect of enlightenment. New York, 1972. In Harvey D A condição pós moderna: uma pesquisa sobre as origens da mudança cultural.

São Paulo: Loyola; 1993.

Instituto Nacional de Saúde no Trabalho/CBN/CUT. A Saúde no Trabalho Bancário. São Paulo: 1993. 
International Labour Office - ILO. Occupational Safety and Health. Series $\mathbf{n}^{\circ} \mathbf{5 6}$. Geneva, 18-24 SEP, 1984.

Izumi PR. O bancário frente à exigência de um novo perfil de qualificação. São Paulo: 1997. [Dissertação de mestrado apresentada à PUC - São Paulo]

Jackson SE, Malash. The measurement of experienced burn out. Journal of Occupational Behaviour. 1981; Vol 2 nº 2 pp 99-113.

Jackson Filho JM Avaliação da incidência de lesões por esforços repetitivos nos setores de compensação bancária e de processamento de dados da região de Florianópolis do Banco do Estado de Santa Catarina: laudo pericial. Florianópolis; FUNDACENTRO; 1993.

Jodelet D La representación social: fenómeno, concepto y teoria. In Moscovici S. Psicologia social. Barcelona: Paidos; 1985.

Kalimo R, El- Batawi MA, Cooper CL. Psychosocial Factors at Work and their relation with health. World Health Organization, Geneva; 1987.

Kaplan HR, Tansky C. the meaning of work among the hard care unemplyed. Pacific Sociological Review. 17, 187-98; 1974. In Keyser V de, Quale T, Wilpert B, Quintanilla SAR. The Meaning of Work and Technological Options. John Wiley e Sons; 1998.

Karjalainen K, Malmivaara A, van Tuder M, Roine R, Janhiainen M, Hurri H, Kroes B. Bio-Psycho-social rehabilitation for upper limb repetitive strain injuries in working age adults. (Cochrane Review) In: The Cochrane Library, Issue 3, 2003.

Keyser V de, Quale T, Wilpert B, Quintanilla SAR. The Meaning of Work and 
Technological Options. John Wiley e Sons; 1998.

Krause N, Dasinger LK, Neuhauser F. Modified work and return to work: a review of the literature. Journal of Occupational Rehabilitation. 1998; 8(2): 113-139.

Lefèvre F, Lefèvre AMC, Teixeira JJV (org) O Discurso do Sujeito Coletivo. Uma nova abordagem em pesquisa qualitativa. Rio Grande do Sul: EDUCS, 1999.

Lefèvre F, Lefèvre AMC O Discurso do Sujeito Coletivo: teoria e prática. São Paulo; 2001. [ Anotações de aula do curso Pesquisa Qualitativa: novas metodologias de análise do Discurso]

Levi L. Definições e aspectos conceituais da saúde em relação ao trabalho. In Kalimo R, El- Batawi MA, Cooper CL. Psychosocial Factors at Work and their relation with health. World Health Organization, Geneva; 1987.

Liepietz A New tendencies in the international division of labour: regimes of accumulation and modes of regulation. In Harvey D. A condição pós moderna: uma pesquisa sobre as origens da mudança cultural. São Paulo: Loyola; 1993.

Lima MEA A LER no setor bancário. In Lima MEA, Araujo JNG de, Lima F de PA. LER. Dimensões ergonômicas e psicossociais. Belo Horizonte: Editora Health; 1998.

Lukács G. História e consciência de classe. Porto: Publicações Escorpião; 1974. In Minayo MC de S. O desafio do Conhecimento. Pesquisa Qualitativa em Saúde. São Paulo/ Rio de Janeiro: HUCITEC/ABRASCO; 1994.

Maeno M. Reinserção de trabalhadores com lesões por esforços repetitivos no mercado de trabalho. São Paulo; 2001 [ Dissertação de Mestrado apresentada à Faculdade de Saúde Pública - USP] 
Magalhães LV. A dor da gente: representações sociais sobre as LER. Campinas; 1998. [Tese de doutorado - Faculdades de Ciências Médicas da Universidade Estadual de Campinas]

Marofuse NT, Marziale MH. Changes in the work and life of bank employees with repetitive strain injury: RSI. Rev. Lat Am Enfermagem. 2001 JUL; 9 (4): 19-25. Marx, K. O Capital. 1867. México; Fundo da Cultura Econômica. Tradução: Amélia Mayall, Antonio Roberto N Blundi, Jose Fernandes Dias.

Minayo MC de S. O desafio do Conhecimento. Pesquisa Qualitativa em Saúde. São Paulo/ Rio de Janeiro: HUCITEC/ABRASCO; 1994.

Ministério da Previdência e Assistência Social. Previdência Social. [on line] Disponível em http://www.previdenciasocial.gov.br

\section{Ministério da Saúde - Lesões por Esforços Repetitivos (LER) Distúrbios}

Osteomusculares Relacionados ao Trabalho (DORT) Série Normas e manuais Técnicos, no 103 Brasília DF; Fev/2001.

Moore LE, Wiesner SL. Hypnotically - Induced vasodication in the treatment of repetitive strain injurie. American J of Clinical Hypnosis. 1996; 39: 97-104.

Morgan G. Imagens da Organização. São Paulo: Atlas;1996.

Morin EM. Os sentidos do trabalho. RAE - Revista de Adm de Empresas JUL/SET $2001 ; 41: 3$.

NIOSH - National Institute of Occupational Safety and Health. Work - related musculoskeletal disorders and psychosocial factors. In: Bernard BP (ed) Musculoskeletal disorders and workplace factors: a critical review of epidemiologic evidence for work related musculoskeletal disorders of the neck, 
upper extremity and low back [documento on line] $2^{\text {rd }}$ ed. Cincinnati: NIOSH, 1997. Disponivel em: http://www.cdc.gov/niosh/ergosil/html

Nordstrom-Bjorverud G, Moritz U. Interdisciplinary rehabilitation of hospital employees with musculoskeletal disorders. Scand J Rehabil Med. 1998, MAR; 30 (1):31-7.

Noreik K, Grunfeld B. Rehabilitation status at a regional social insurance office experiences with 103 clients at Grunerlokka - Sofienberg office. Tidsskk nor Laegeforen. 1995, May 30; 115 (14): 1718-20.

Oliveira PS de (org.). Metodologia das Ciências Humanas. São Paulo: Ed. Hucitec; 1998.

Oliver FC. Reflexões sobre a relação entre trabalho e saúde e as propostas de intervenção em terapia ocupacional. Rev. Ter Ocup. 1990, 1(2):76-80.

Organização Mundial da Saúde. Identification and control of work-related diseases. OMS, Technical Report Series. Geneva, 1985, 714: 72p.

Organização Internacional do trabalho. Recomendación sobre los servicios de medicina del trabajo em los lugares de empleo [Recomendación $\mathrm{n}^{\mathbf{0}} 112$ de la OIT adaptada em 24 de junio de 1959]. In Mendes Ribeiro AC. LER. Porto Alegre SINDPD/RS, $19864 \mathrm{p}$ [mimeografado]

Pagotto MAF. Mito e realidade na automação bancária. Campinas; 1996 [Dissertação de mestrado apresentada ao Departamento de ciências Humanas da UNICAMP] 
Ramazzini B. As doenças dos trabalhadores. Trad. Estrela R São Paulo: FUNDACENTRO; 1985

Ribeiro, HP Lesões por Esforços Repetitivos (LER): uma doença emblemática.

Cad. S. Pública. 1997; 13 (Supl 2): 85 - 93.

Ribeiro, HP. A violência oculta do trabalho: as lesões por esforços repetitivos. Rio de Janeiro: FIOCRUZ; 1999.

Rocha, LE. Tenossinovite e trabalho: análise das CAT's registradas no município de São Paulo. São Paulo; 1989. [ Dissertação de mestrado da Faculdade Paulista de Medicina da USP]

Romanelli G. O provisório definitivo: trabalho e aspirações de bancários em São Paulo. São Paulo, 1978. [Dissertação de Mestrado apresentada ao Departamento de Ciências Sociais da FFLCH/USP]. In Izumi PR. O bancário frente à exigência de um novo perfil de qualificação. São Paulo, 1997 [Dissertação de mestrado apresentada à PUC - São Paulo].

Sabel C e Piore M The second Industrial Divide. New York: Basic Books, 1984. In Antunes, R. Adeus Ao Trabalho? Ensaio Sobre As Metamorfoses e a

Centralidade Do Mundo Do Trabalho. São Paulo: Cortez; 1995.

Sato $\mathrm{L}$ et al. Atividade em grupo com portadores de LER e achados sobre a dimensão psicossocial. Rev. Bras. De Saúde Ocupacional JUL/AGO/SET/1993; 21 (49-62)

Schweller OG Coluna vertebral e reabilitação profissional. Rev. Bras Reumatol. 1983; 23(4): 132-4.

Secretaria de Estado da Saúde de São Paulo. Resoluções 180 e 197. Norma Técnica para LER. São Paulo; 1992 
Segnini LRP. Mulheres no trabalho bancário. Difusão tecnológica, qualificação e relações de gênero. São Paulo: EDUSP; 1998

Seligman Silva ES Saúde Mental e Trabalho. In: Tunds S, Costa N (org) Cidadania Loucura: Políticas de saúde Mental no Brasil. Petrópolis: Vozes/ABRASCO; 1987.

Seligmann Silva E A inter - relação trabalho - saúde mental: um estudo de caso. Rev Adm de Empresas. 1992; 32 (4): 70 - 90.

Seligman Silva E Desgaste Mental no Trabalho Dominado. São Paulo; Cortez: 1994.

Seligmann Silva E Psicopatologia e psicodinâmica no trabalho. In Mendes R (org) Patologia do trabalho. Ed. Atheneu; 1995.

Sennet R. A corrosão do caráter consequências pessoais do trabalho no novo capitalismo. Rio de Janeiro: Record; 1999.

Siqueira AR, Queiroz MFF. Abordagem grupal em saúde do trabalhador. O Mundo da Saúde. $2001 ; 25(4): 411-419$.

Silva RA. Computadores, digitação e caixas: A automação bancária em questão. In: Silva RA, Leite MP. Modernização tecnológica, relações de trabalho e práticas de resistência. São Paulo: IGLU/IDES/LABOR; 1991.

Sontag S A doença como metáfora. Rio de Janeiro: Graal; 1984.

Spence SH, Sharpe L, Newton - John, Champion D. Effect of EGM biofeedback compared to applied relaxation training with chronic upper extremity cumulative trauma disorders pain, 1995; 63 (2): 199-206. 
Spink MJP. O conceito de Representação Social na Abordagem Psicossocial.

Cadernos de Saúde Pública. 1993, 9(3): 300-308.

Straaton KV, Maisiak R, Wrigley JM, Fine PR. Musculoskeletal disability, employment and rehabilitation. J Rheumatol. 1995, MAR; 22 (3): 505-13.

Struffaldi MCB Conhecimento, opinião e conduta de médicos peritos acidentários face à programação do Centro de Reabilitação Profissional do INPS, do Município de São Paulo. São Paulo; 1987 [Dissertação de mestrado apresentada à Faculdade de Saúde Pública - USP]

Struffaldi MCB Reabilitação Profissional: características, conhecimentos e opiniões de trabalhadores acidentados. São Paulo; 1994. [Tese de doutorado apresentada à Faculdade de Saúde Pública - USP]

Takahashi MABC e Canesqui AM Pesquisa avaliativa em reabilitação profissional: a efetividade de um serviço em desconstrução. Cad. Saúde Pública; 2003; 19(5): 14731483.

Yu IT, Wong TW. Musculoskeletal problems among VDU workers in a Hong Kong bank. Occup Med (Lond). 1996 AUG; 46 (4): 275 - 80.

Weber M. The Theory of Social and Economic Organization. London: Oxford University Press, 1947. In Morgan G. Imagens da Organização. São Paulo: Atlas; 1996. 
ANEXOS 
Quadro Resumo do Total de empregados atendidos no PRT - Programa de Readaptação ao Trabalho do Banco estudado no âmbito do SESMT - Serviço de Engenharia de Segurança e Medicina do Trabalho em São Paulo 


\title{
PRT - Programa de Readaptação ao Trabalho
}

\section{Acompanhamento de demanda e atendimento}

\author{
Local: São Paulo
}

Ano: 2003 Trimestre: Jul/Ago/Set

Número total de empregados na filial: $\mathbf{8 1 2 6}$

\begin{tabular}{|l|l|l|l|l|l|l|l|}
\hline & $\begin{array}{l}\text { Originada } \\
\text { pelos gerentes }\end{array}$ & $\begin{array}{l}\text { Auxílio } \\
\text { Doença }\end{array}$ & $\begin{array}{l}\text { Auxílio } \\
\text { Doença } \\
\text { Acidentário }\end{array}$ & $\begin{array}{l}\text { Nova função } \\
\text { sem } \\
\text { afastamento }\end{array}$ & Reinscrições & Outros casos & TOTAL \\
\hline Demanda & 29 & 228 & 210 & 4 & 4 & 96 & 571 \\
\hline Inscrições & 29 & 196 & 210 & 4 & 4 & 96 & 539 \\
\hline
\end{tabular}

\begin{tabular}{|l|l|l|l|}
\hline & Com afastamento & \multicolumn{1}{|c|}{ Sem afastamento } & TOTAL \\
\hline Fase de Atenção à Saúde & 125 & 16 & 141 \\
\hline $\begin{array}{l}\text { Fase de Potencialização } \\
\text { Laborativa }\end{array}$ & 3 & 13 & 16 \\
\hline
\end{tabular}

\section{DESLIGADOS DO PROGRAMA}

\begin{tabular}{|c|c|c|c|c|}
\hline Readaptados & Aposentados & Não Readaptados & Outros & TOTAL \\
\hline 175 & 96 & 6 & 105 & 382 \\
\hline
\end{tabular}

\section{INFORMAÇÕES ADICIONAIS}

\begin{tabular}{|c|c|c|c|}
\hline Voltaram à licença & $\begin{array}{c}\text { Indicados para } \\
\text { Aposentadoria }\end{array}$ & Doentes Crônicos & Inscrições Rejeitadas \\
\hline 1 & 12 & 58 & 0 \\
\hline
\end{tabular}

\section{DIAGNÓSTICO}

\begin{tabular}{|c|c|c|c|}
\hline LER/DORT & SAÚDE & PSIQUIATRIA & TOTAL \\
\hline 210 & 158 & 171 & 539 \\
\hline
\end{tabular}

Fonte: Programa de Readaptação ao Trabalho - PRT - Planilhas 


\section{ANEXO II}

Quadros com dados demográficos da população total de empregados atendidos pelo PRT - Programa de Readaptação ao Trabalho do Banco estudado no âmbito do SESMT - Serviço de Engenharia de Segurança e Medicina do Trabalho em São Paulo 
POPULAÇÃO ATENDIDA PELO PRT - PROGRAMA DE READAPTAÇÃO AO TRABALHO DO BANCO ESTUDADO COM DIAGNÓSTICO DE LER E SUJEITOS QUE PARTICIPARAM DAS ENTREVISTAS COM RELAÇÃO AO SEXO, ESTADO CIVIL, IDADE E GRAU DE INSTRUÇÃO

\begin{tabular}{|c|r|r|}
\hline SEXO & $N^{\circ}$ LER - PRT & N $^{\circ}$ SUJEITOS \\
\hline MASCULINO & $38(18 \%)$ & $2(12 \%)$ \\
\hline FEMININO & $172(82 \%)$ & $14(88 \%)$ \\
\hline TOTAL & $210(100 \%)$ & $16(100 \%)$ \\
\hline
\end{tabular}

\begin{tabular}{|l|r|r|r|r|}
\hline ESTADO CIVIL & HOMENS PRT & MULHERES PRT & HOMENS SUJEITOS & MULHERES SUJEITOS \\
\hline Solteiros & $8(21 \%)$ & $38(22 \%)$ & $1(50 \%)$ & $5(36 \%)$ \\
\hline Casados & $28(74 \%)$ & $101(59 \%)$ & $1(50 \%)$ & $8(57 \%)$ \\
\hline Desq/divor/sep & $2(5 \%)$ & $32(18 \%)$ & 0 & $1(7 \%)$ \\
\hline Viúvos & 0 & $1(1 \%)$ & 0 & 0 \\
\hline TOTAL & $38(100 \%)$ & $172(100 \%)$ & $2(100 \%)$ & $14(100 \%)$ \\
\hline
\end{tabular}

\begin{tabular}{|l|r|r|r|r|}
\hline IDADE & HOMENS PRT & MULHERES PRT & HOMENS SUJEITOS & MULHERES SUJEITOS \\
\hline 31 a 40 anOS & $7(18 \%)$ & $38(22 \%)$ & 0 & $3(22 \%)$ \\
\hline 41 a 50 anos & $24(64 \%)$ & $122(71 \%)$ & $2(100 \%)$ & $11(78 \%)$ \\
\hline 51 a 60 anos & $7(18 \%)$ & $12(7 \%)$ & 0 & 0 \\
\hline TOTAL & $38(100 \%)$ & $172(100 \%)$ & $2(100 \%)$ & $14(100 \%)$ \\
\hline
\end{tabular}

\begin{tabular}{|l|r|r|r|r|}
\hline INSTRUÇÃO & HOMENS - PRT & MULHERES - PRT & HOMENS SUJEITOS & MULHERES SUJEITOS \\
\hline Alfabetizado & $1(3 \%)$ & $1(0 \%)$ & 0 & 0 \\
\hline Fundamental & $1(3 \%)$ & $2(1 \%)$ & 0 & 0 \\
\hline Médio & $18(47 \%)$ & $60(35 \%)$ & $1(50 \%)$ & $10(71 \%)$ \\
\hline Superior & $15(39 \%)$ & $103(60 \%)$ & $1(50 \%)$ & $4(29 \%)$ \\
\hline Pós Graduação & 0 & $2(1 \%)$ & 0 & 0 \\
\hline Não Informado & $3(8 \%)$ & $4(3 \%)$ & 0 & 0 \\
\hline TOTAL & $38(100 \%)$ & $172(100 \%)$ & $2(100 \%)$ & $14(100 \%)$ \\
\hline
\end{tabular}


POPULAÇÃO ATENDIDA PELO PRT - PROGRAMA DE READAPTAÇÃO AO TRABALHO DO BANCO ESTUDADO COM DIAGNÓSTICO DE LER E SUJEITOS QUE PARTICIPARAM DAS ENTREVISTAS QUANTO À FUNÇÃO ANTERIOR

\begin{tabular}{|l|r|r|r|r|}
\hline FUNÇĀO ANTERIOR & HOMENS PRT & MULHERES PRT & HOMENS SUJEITOS & MULHERES SUJEITOS \\
\hline Caixa & 27 & 103 & 2 & 10 \\
\hline Escriturário S Função & 5 & 9 & 0 & 0 \\
\hline Supervisor & 0 & 14 & 0 & 3 \\
\hline Gerente & 0 & 9 & 0 & 0 \\
\hline Técnico Nivel Médio & 1 & 7 & 0 & 0 \\
\hline Advogado & 0 & 2 & 0 & 0 \\
\hline Secretário & 1 & 4 & 0 & 0 \\
\hline Auxiliar Mercado & 0 & 3 & 0 & 0 \\
\hline Telefonista & 0 & 1 & 0 & 0 \\
\hline Avaliador & 0 & 2 & 0 & 0 \\
\hline Assistente & 1 & 3 & 0 & 1 \\
\hline Auxiliar Supervisão & 1 & 8 & 0 & 0 \\
\hline Tesoureiro & 0 & 2 & 0 & 0 \\
\hline Aux. Serviços Gerais & 2 & 1 & 0 & 0 \\
\hline Analista & 0 & 2 & 0 & 0 \\
\hline Chefe de setor & 0 & 1 & 0 & 0 \\
\hline Operador & 0 & 1 & 0 & 14 \\
\hline TOTAL & 38 & 172 & 2 & 0 \\
\hline
\end{tabular}




\begin{tabular}{|l|r|r|r|r|}
\hline FUNÇÃO ATUAL & HOMENS PRT & MULHERES PRT & HOMENS SUJEITOS & MULHERES SUJEITOS \\
\hline Escriturário S Funçáo & 21 & 67 & 2 & 8 \\
\hline Gerente Eventual & 2 & 27 & 0 & 1 \\
\hline Gerente Efetivo & 2 & 7 & 0 & 0 \\
\hline Supervisor & 1 & 8 & 0 & 2 \\
\hline Analista & 2 & 5 & 0 & 1 \\
\hline Técnico Nivel Módio & 0 & 5 & 0 & 1 \\
\hline Advogado & 0 & 5 & 0 & 0 \\
\hline Tesoureiro & 0 & 2 & 0 & 0 \\
\hline Secretário & 0 & 2 & 0 & 0 \\
\hline Assistente & 0 & 1 & 0 & 0 \\
\hline Agente Empresarial & 0 & 1 & 0 & 0 \\
\hline Aux Serviços Gerais & 2 & 1 & 0 & 0 \\
\hline Avaliador & 1 & 0 & 0 & 0 \\
\hline Demitido & 1 & 0 & 0 & 0 \\
\hline Aposentadoria Invalidez & 3 & 0 & 0 & 0 \\
\hline PADV & 4 & 19 & 0 & 0 \\
\hline Aposent. Tempo Serv. & 1 & 7 & 0 & 14 \\
\hline TOTAL & 38 & 172 & 2 & 0 \\
\hline
\end{tabular}




\title{
ANEXO III
}

\section{Instrumento de Análise do Discurso I}

\author{
IAD I
}




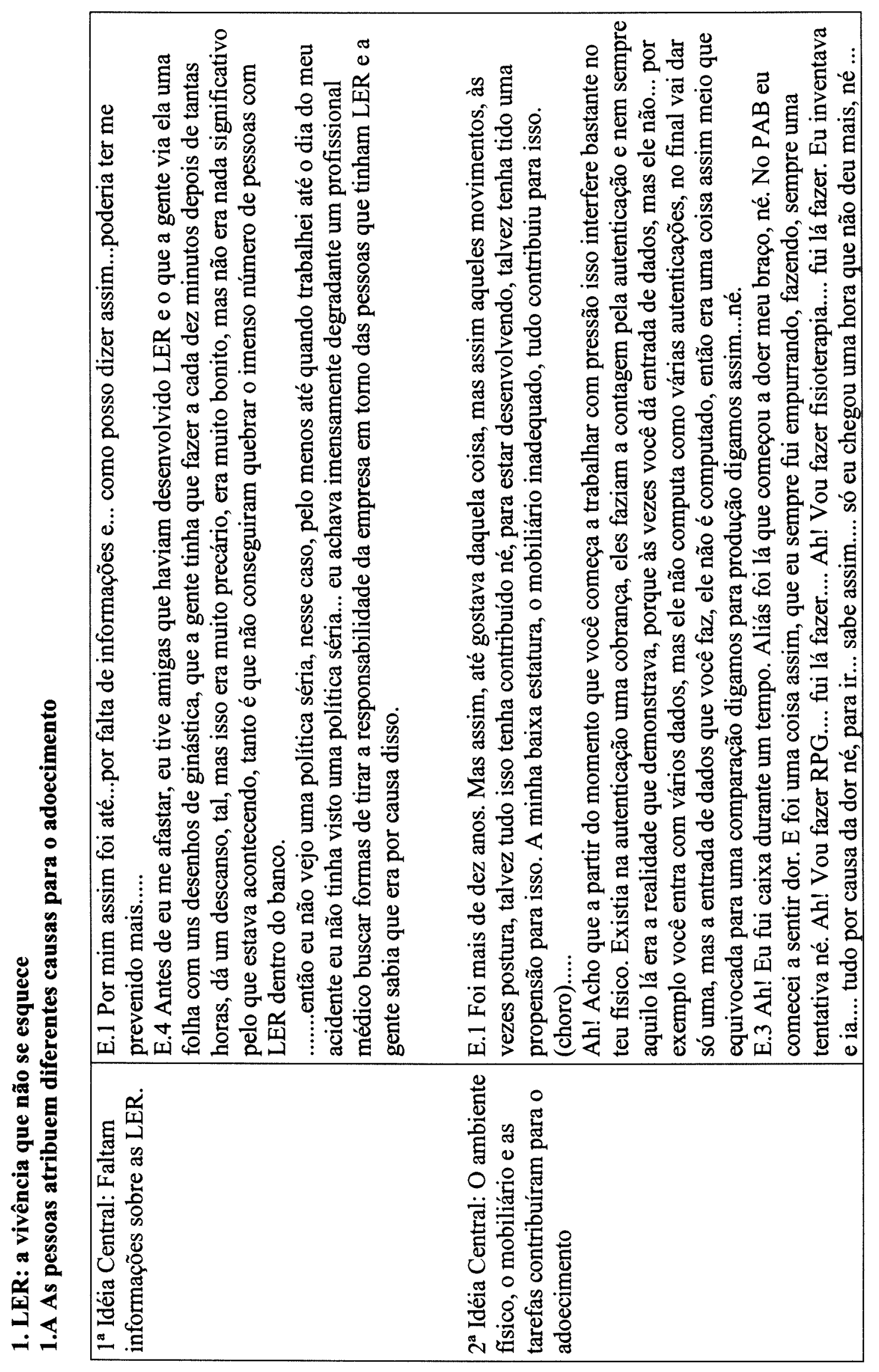




\begin{tabular}{|c|c|}
\hline 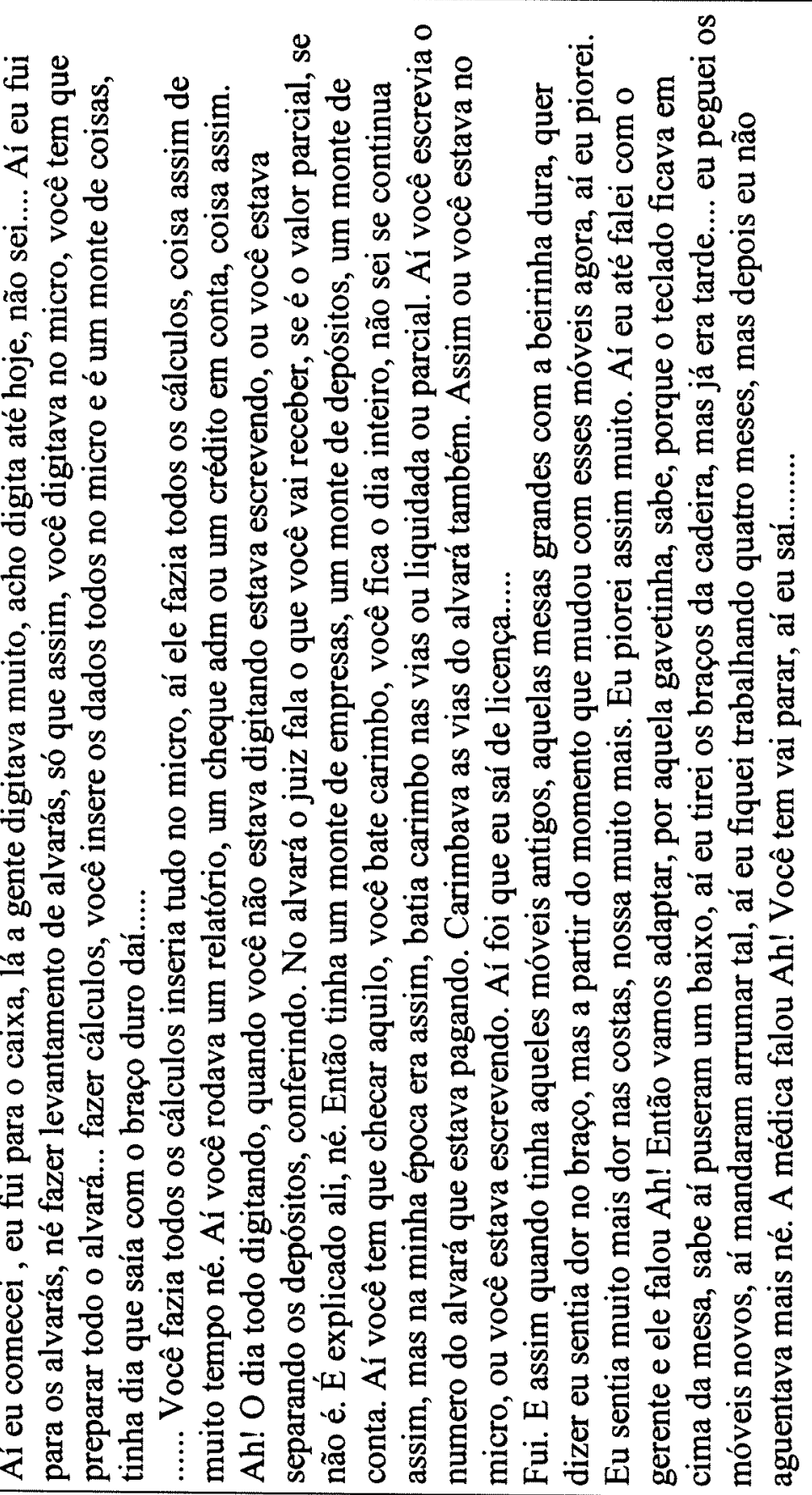 & 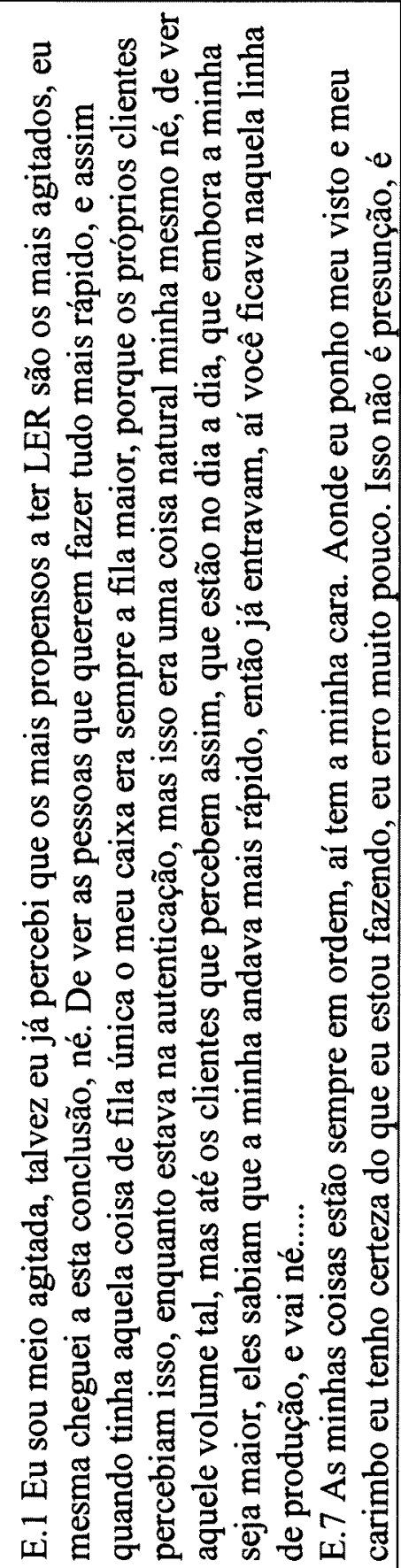 \\
\hline & 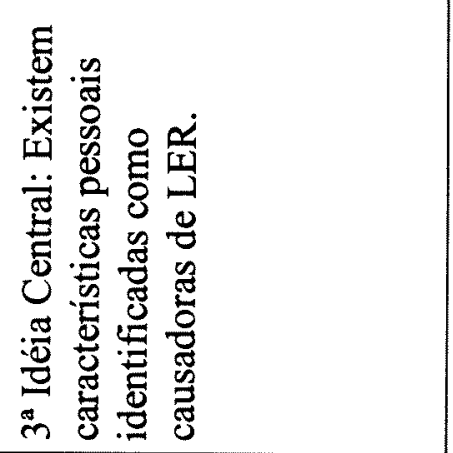 \\
\hline
\end{tabular}




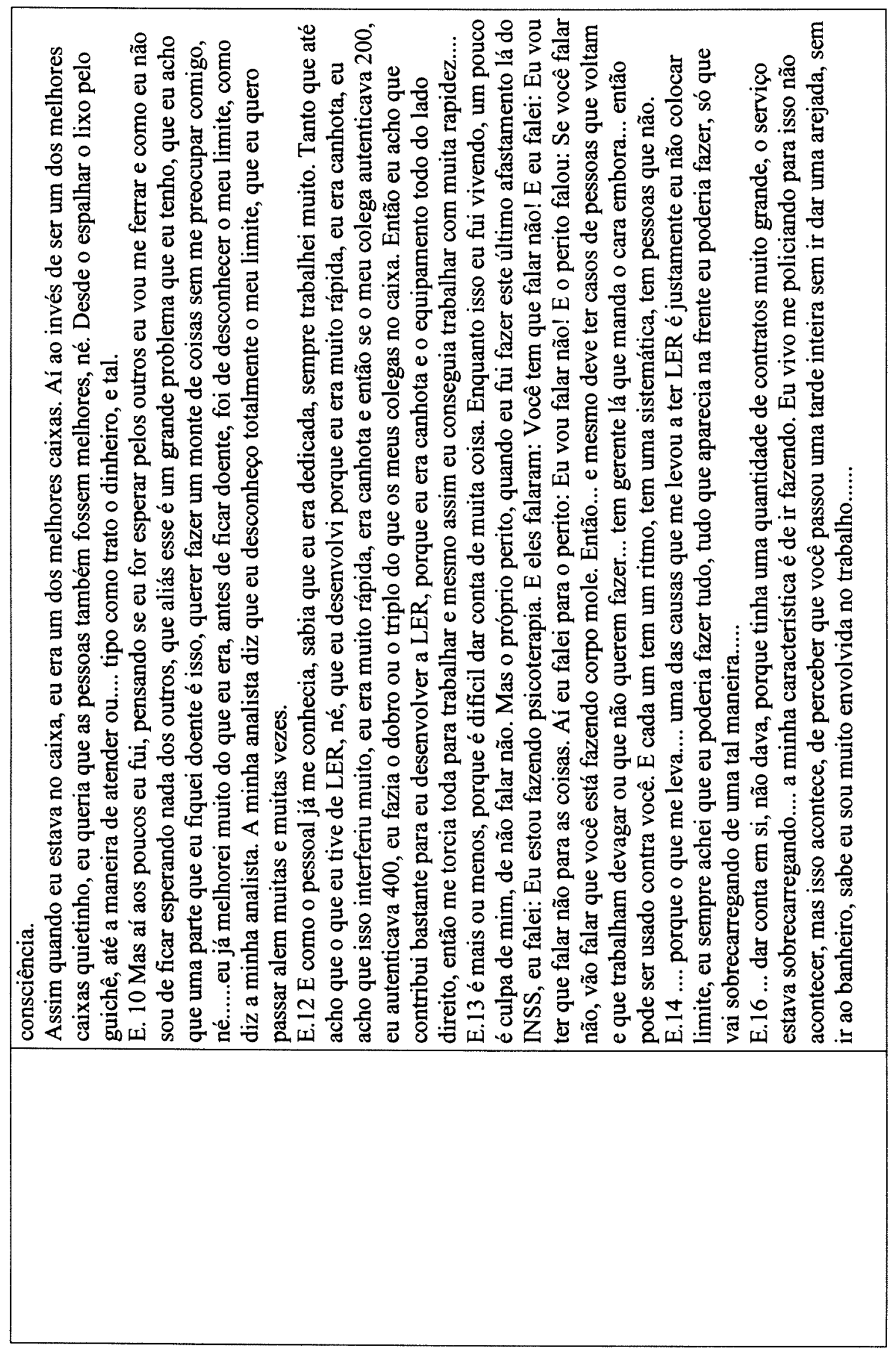




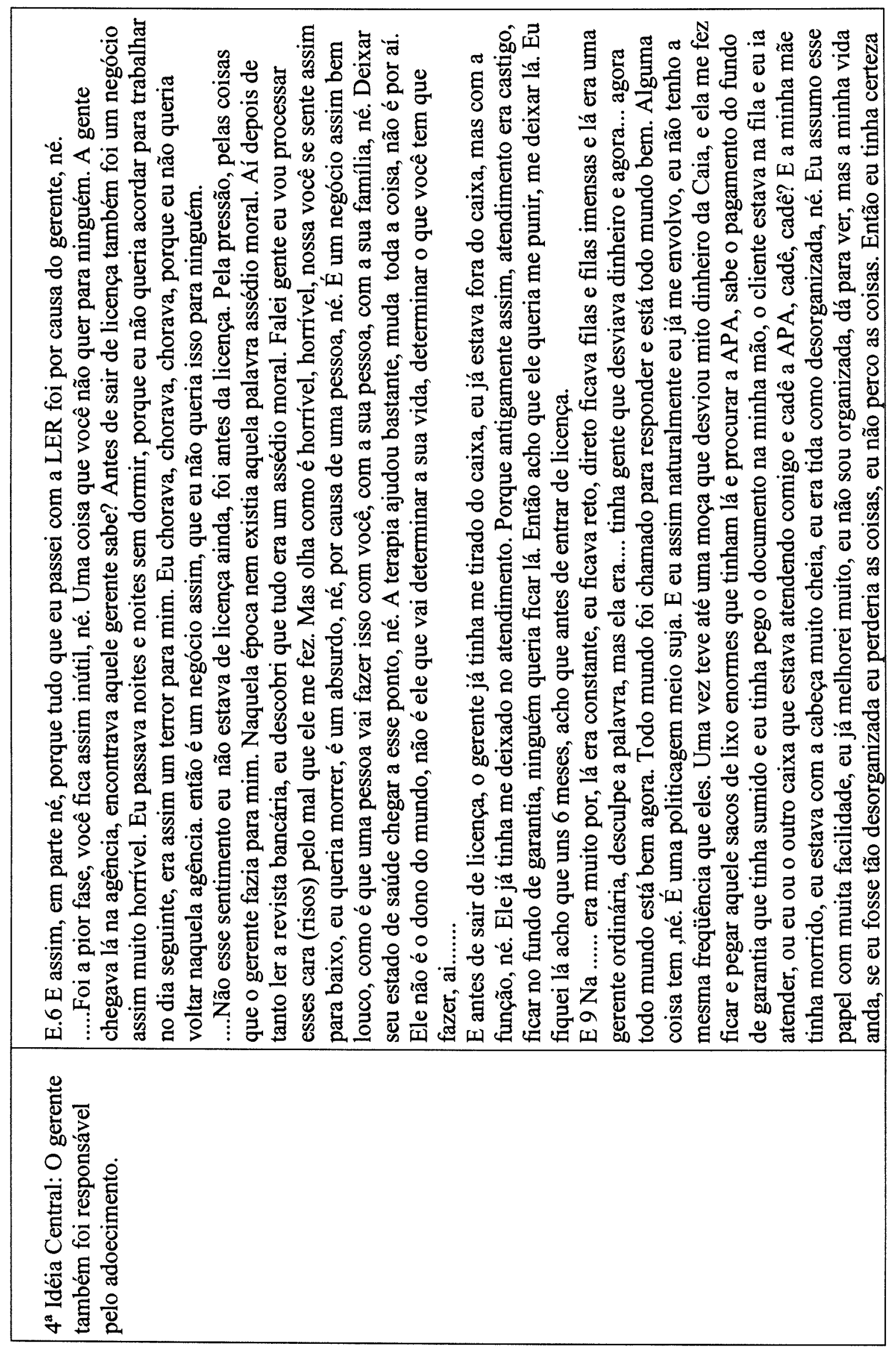




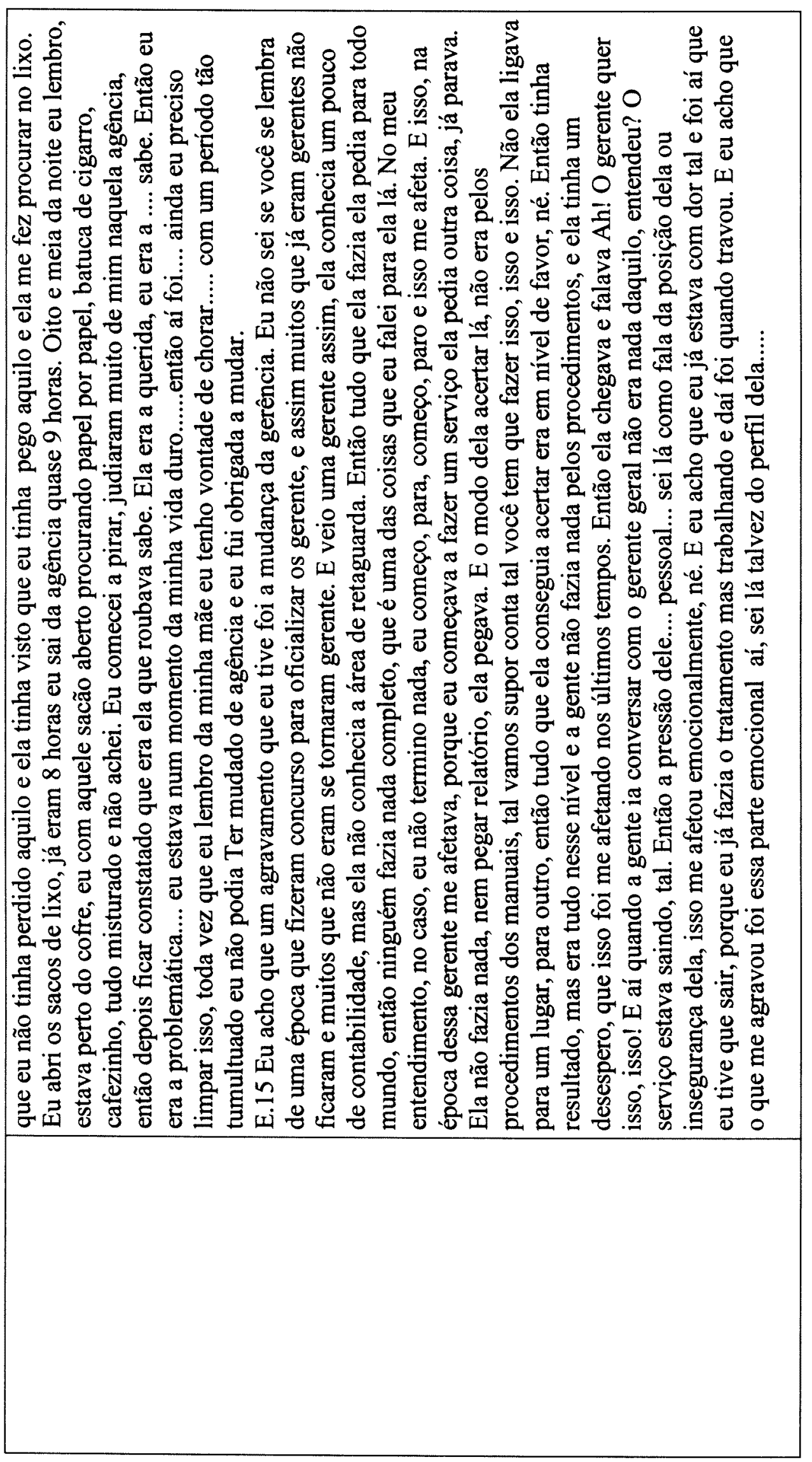




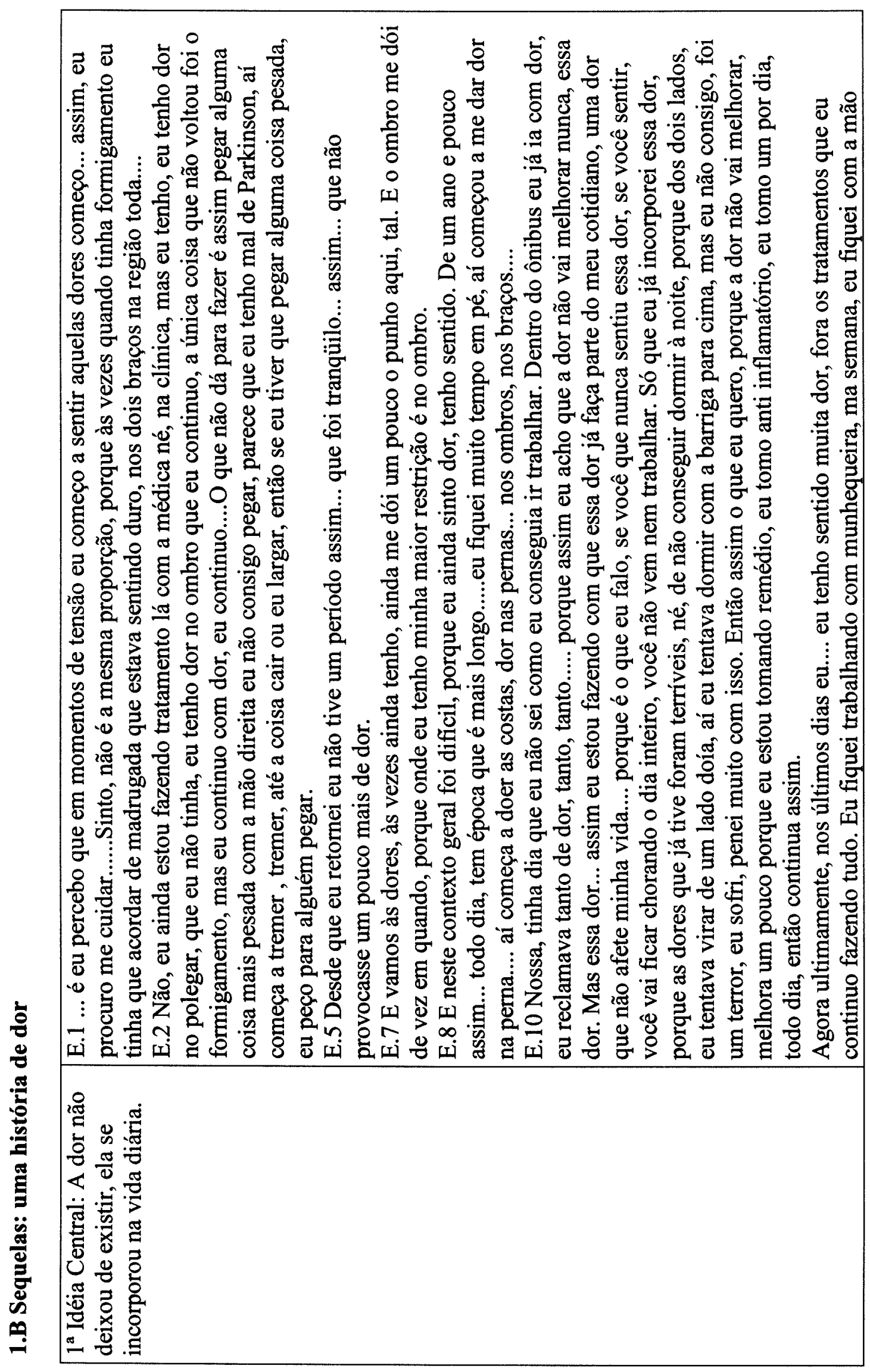




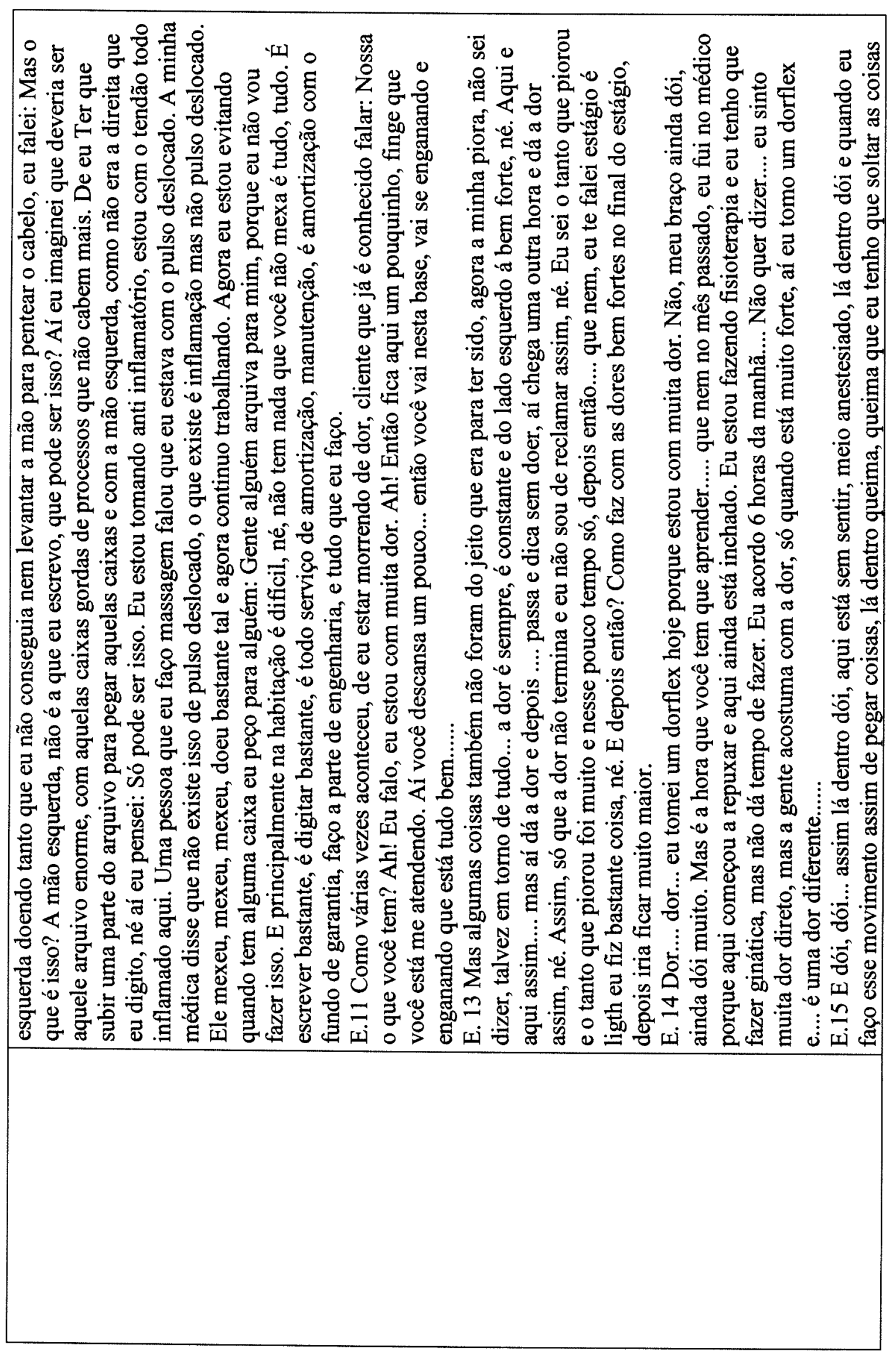




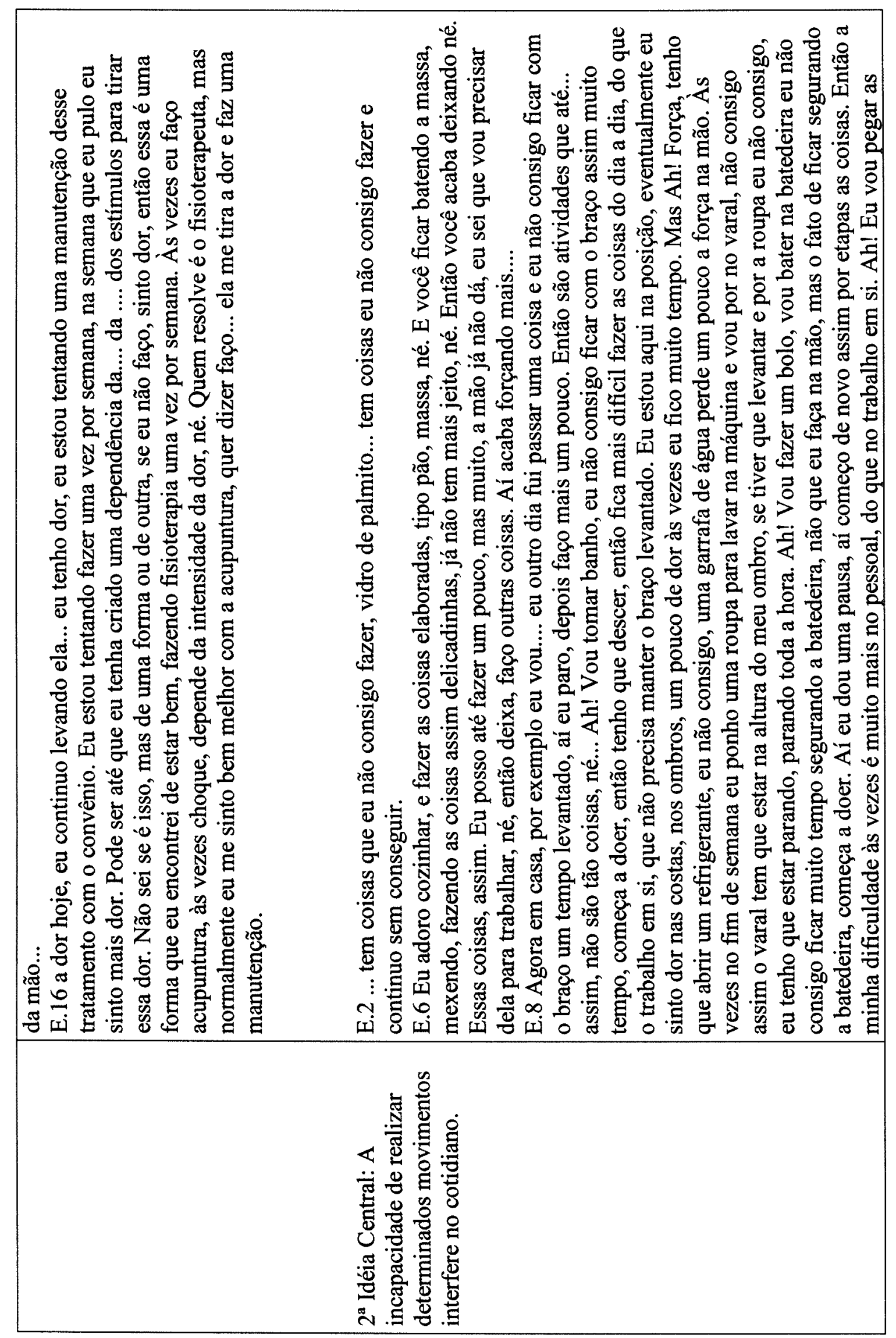




\begin{tabular}{|c|c|}
\hline 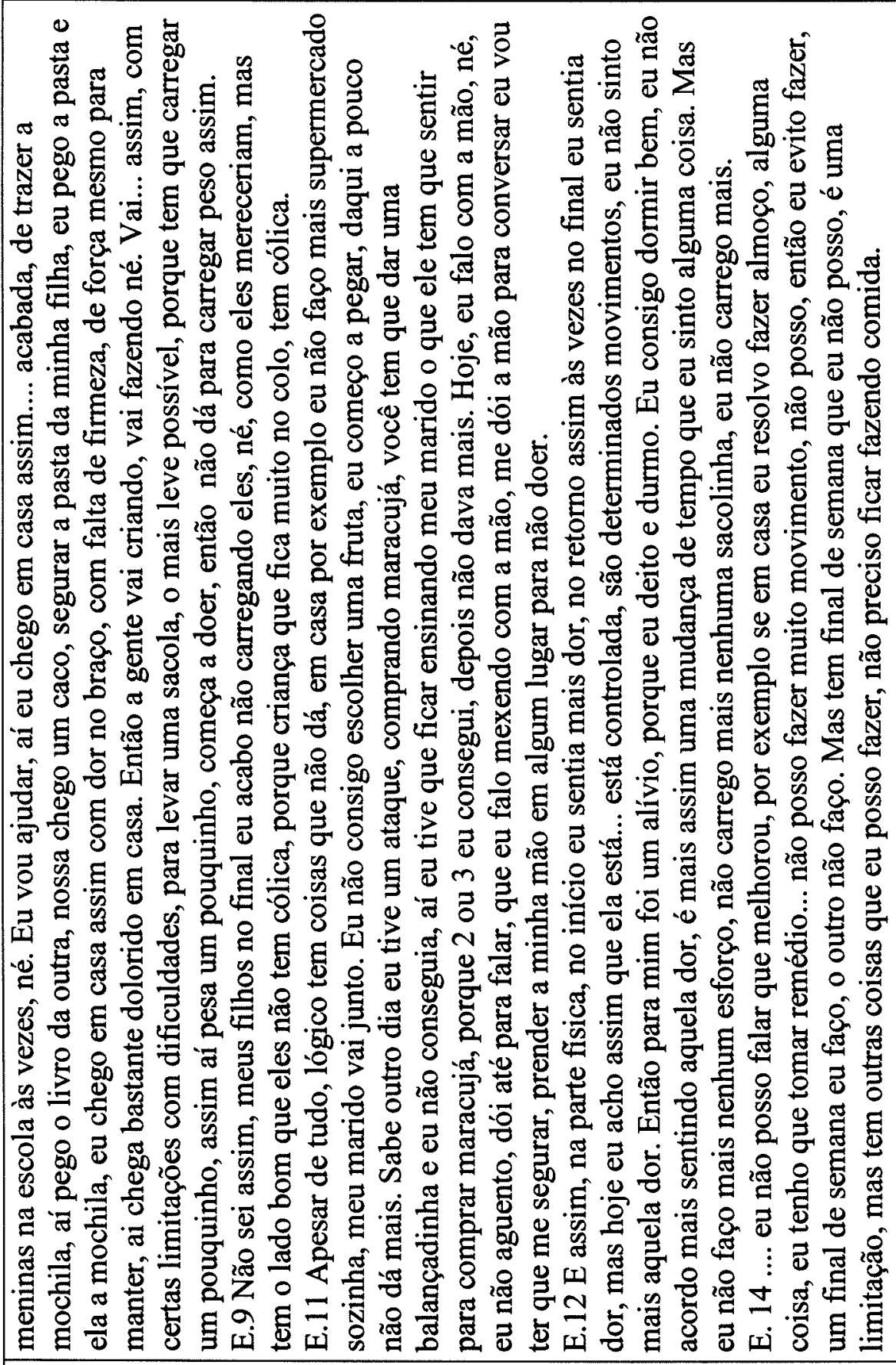 & 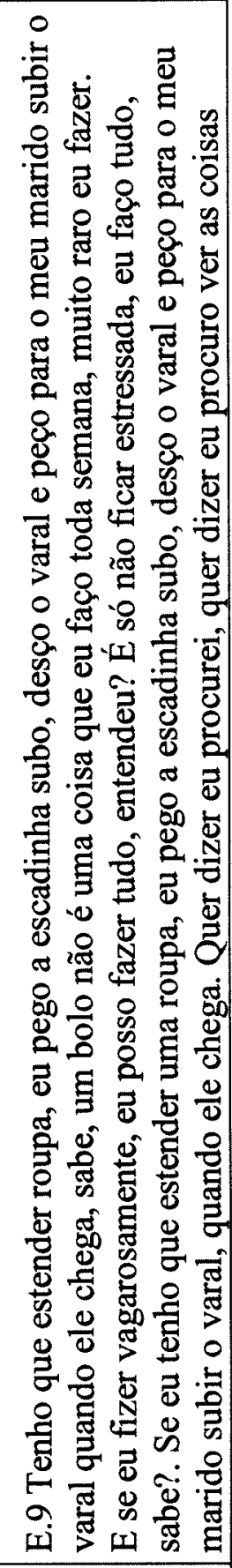 \\
\hline & 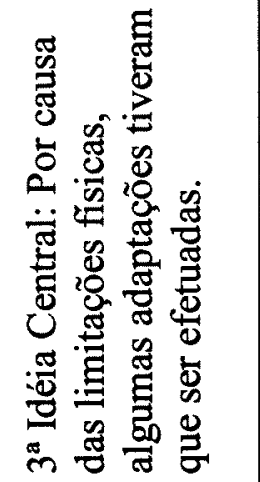 \\
\hline
\end{tabular}




\begin{tabular}{|c|c|}
\hline 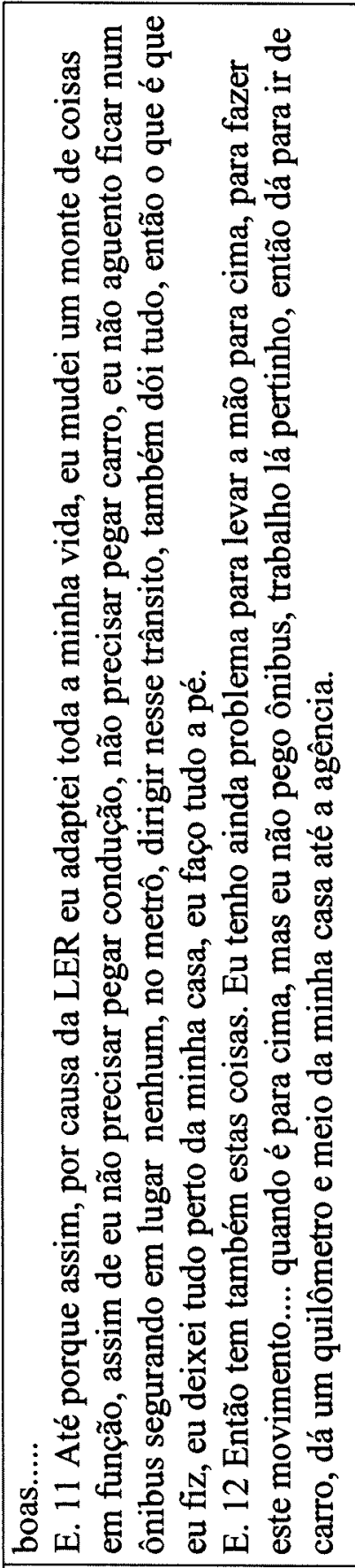 & 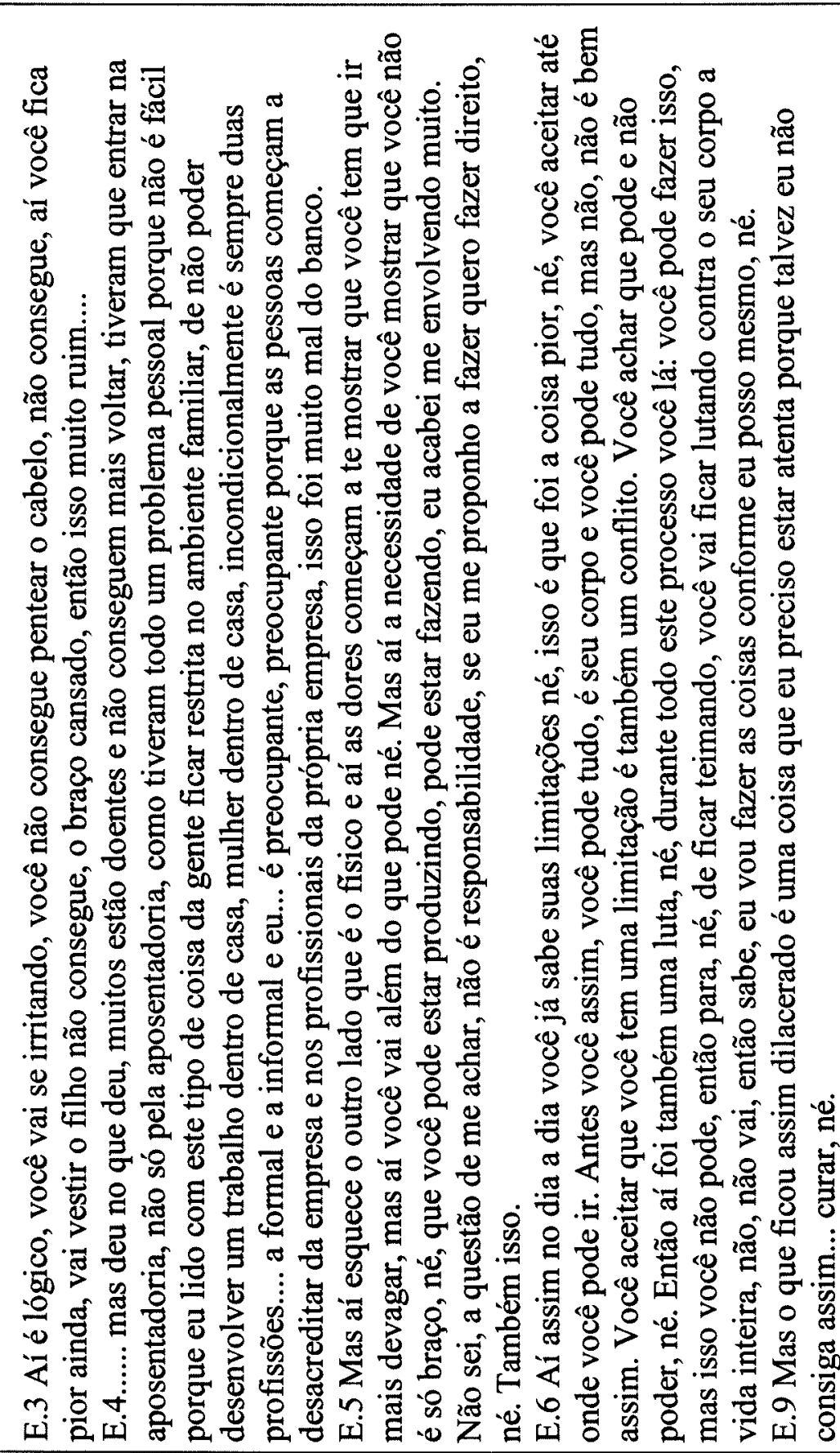 \\
\hline & 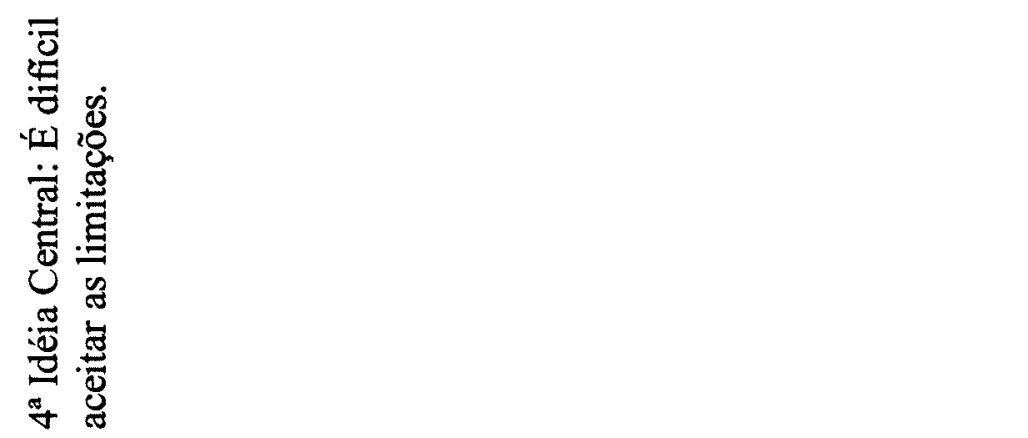 \\
\hline
\end{tabular}




\begin{tabular}{|c|c|c|c|}
\hline 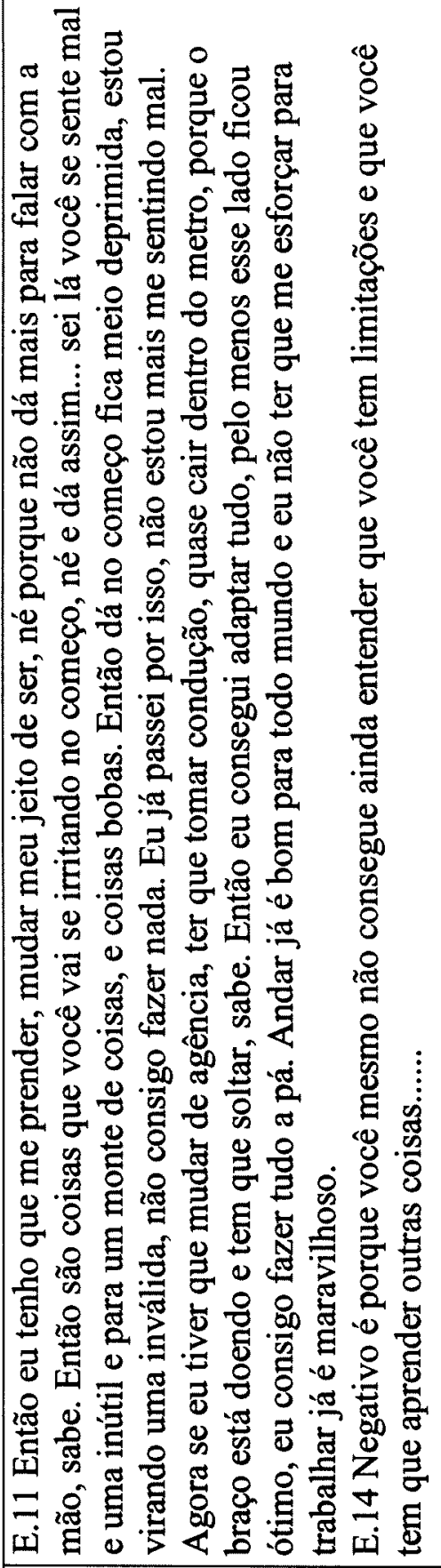 & 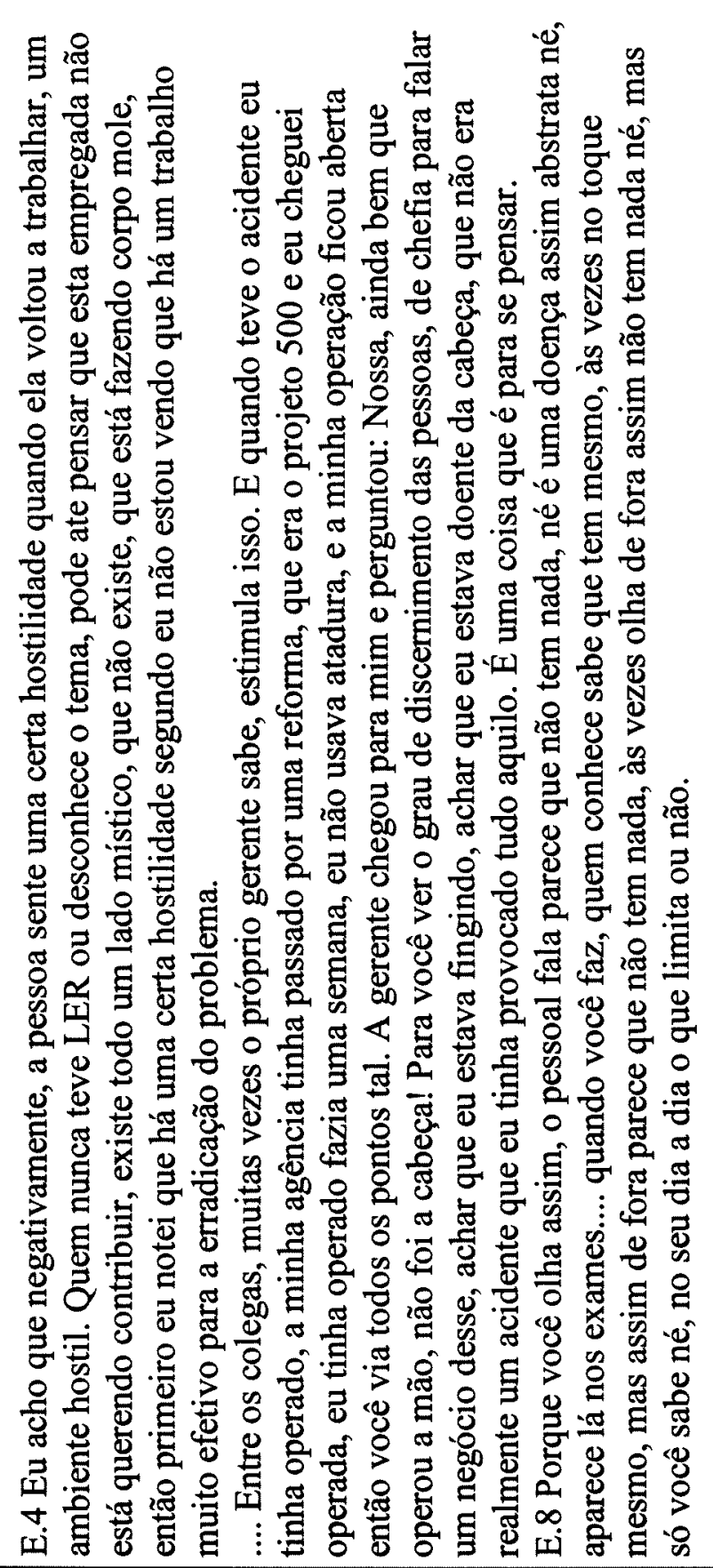 & 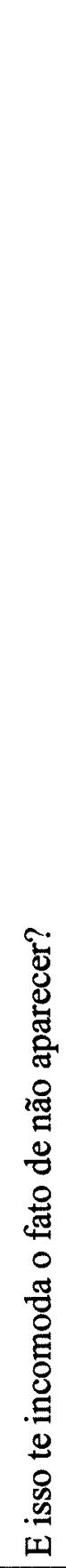 & $\begin{array}{c}0 \\
\dot{a} \\
0\end{array}$ \\
\hline & 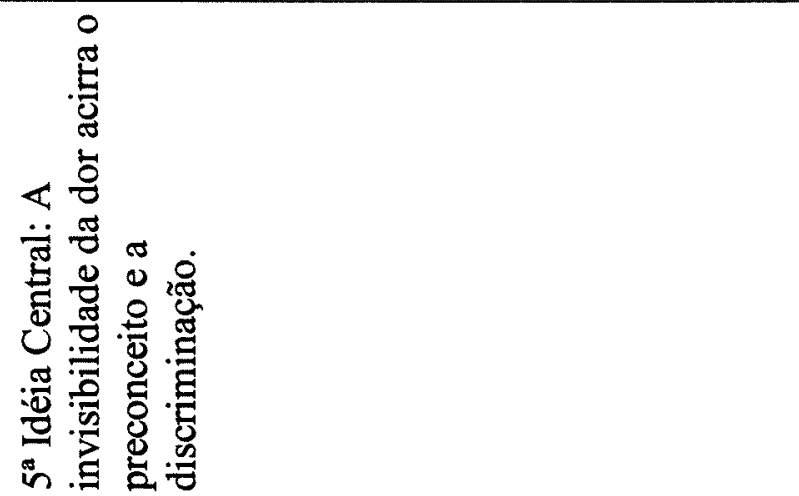 & & \\
\hline
\end{tabular}




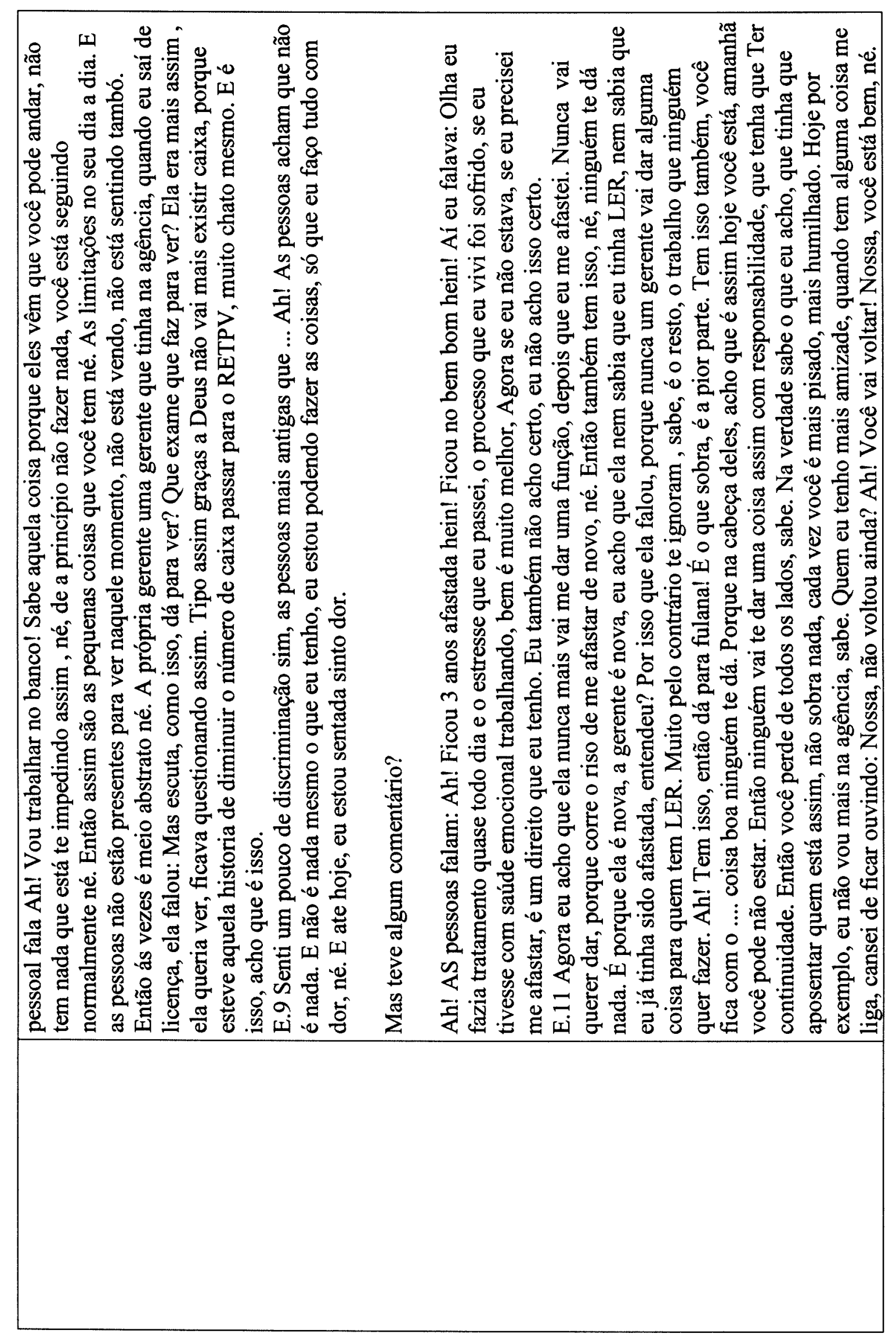




\begin{tabular}{|c|c|c|}
\hline 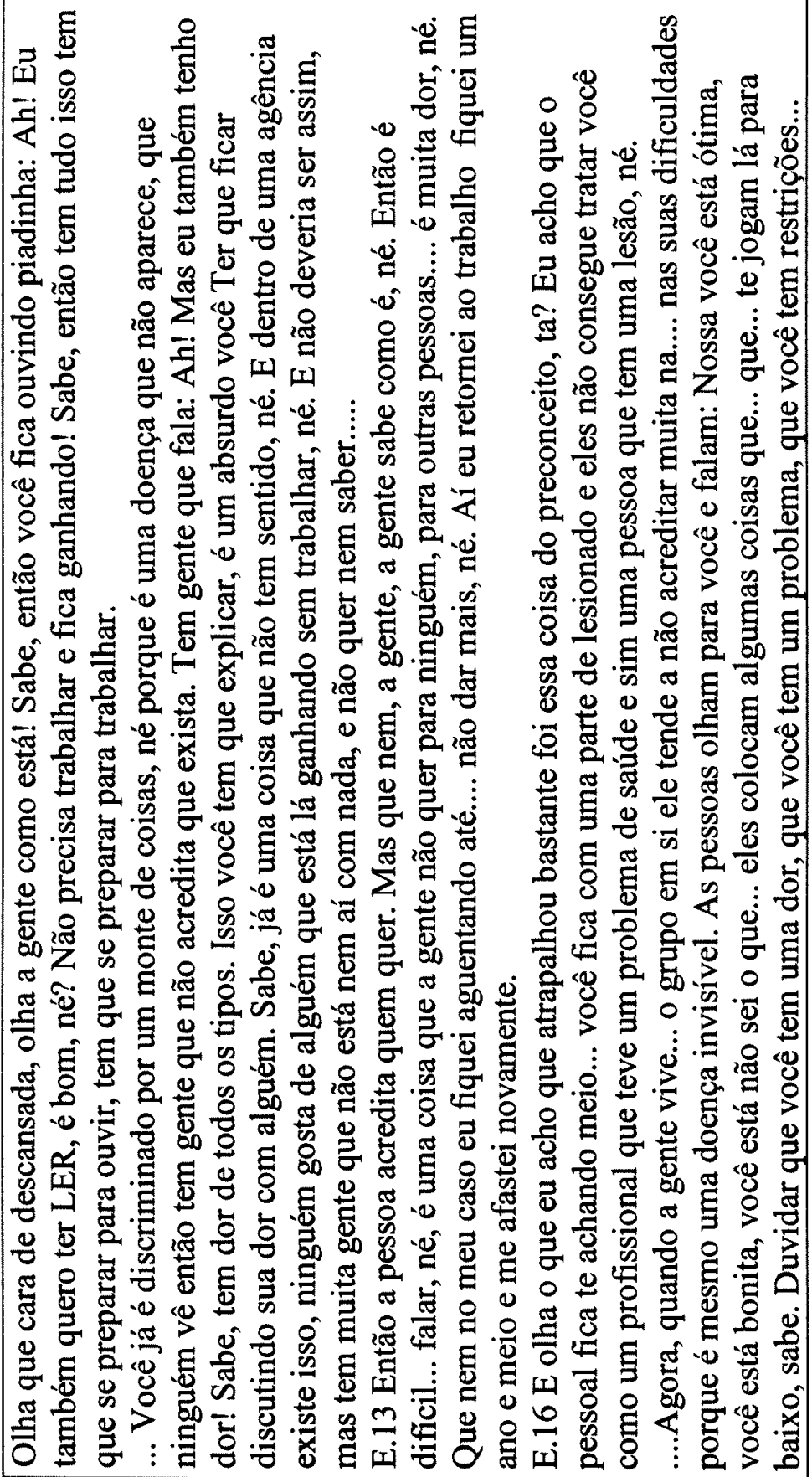 & 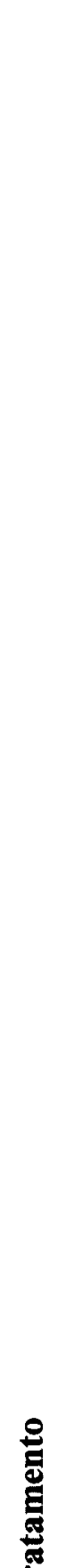 & 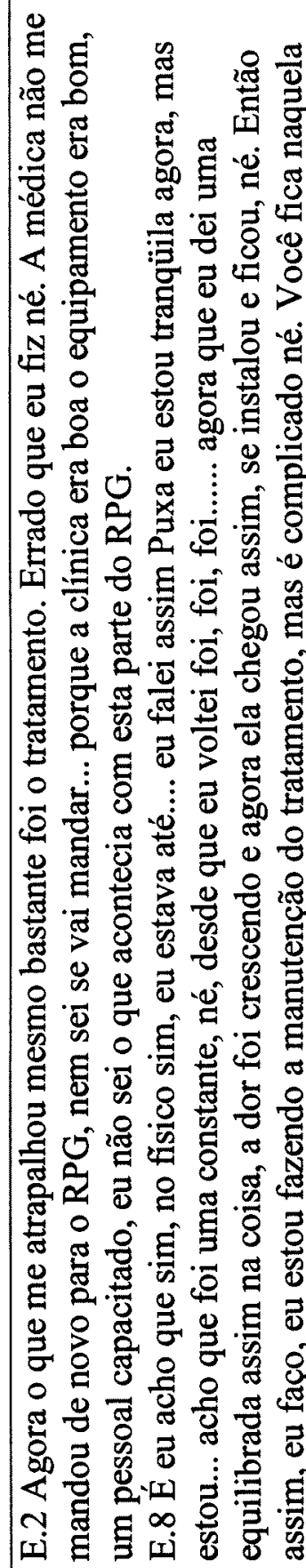 \\
\hline & 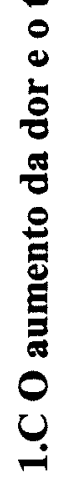 & 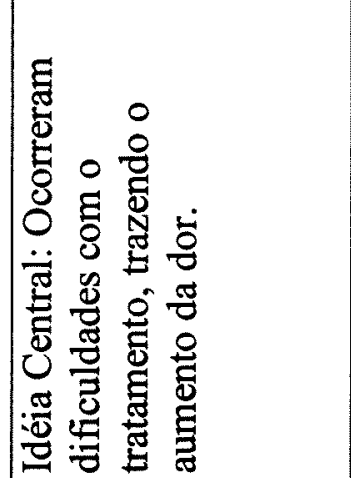 \\
\hline
\end{tabular}




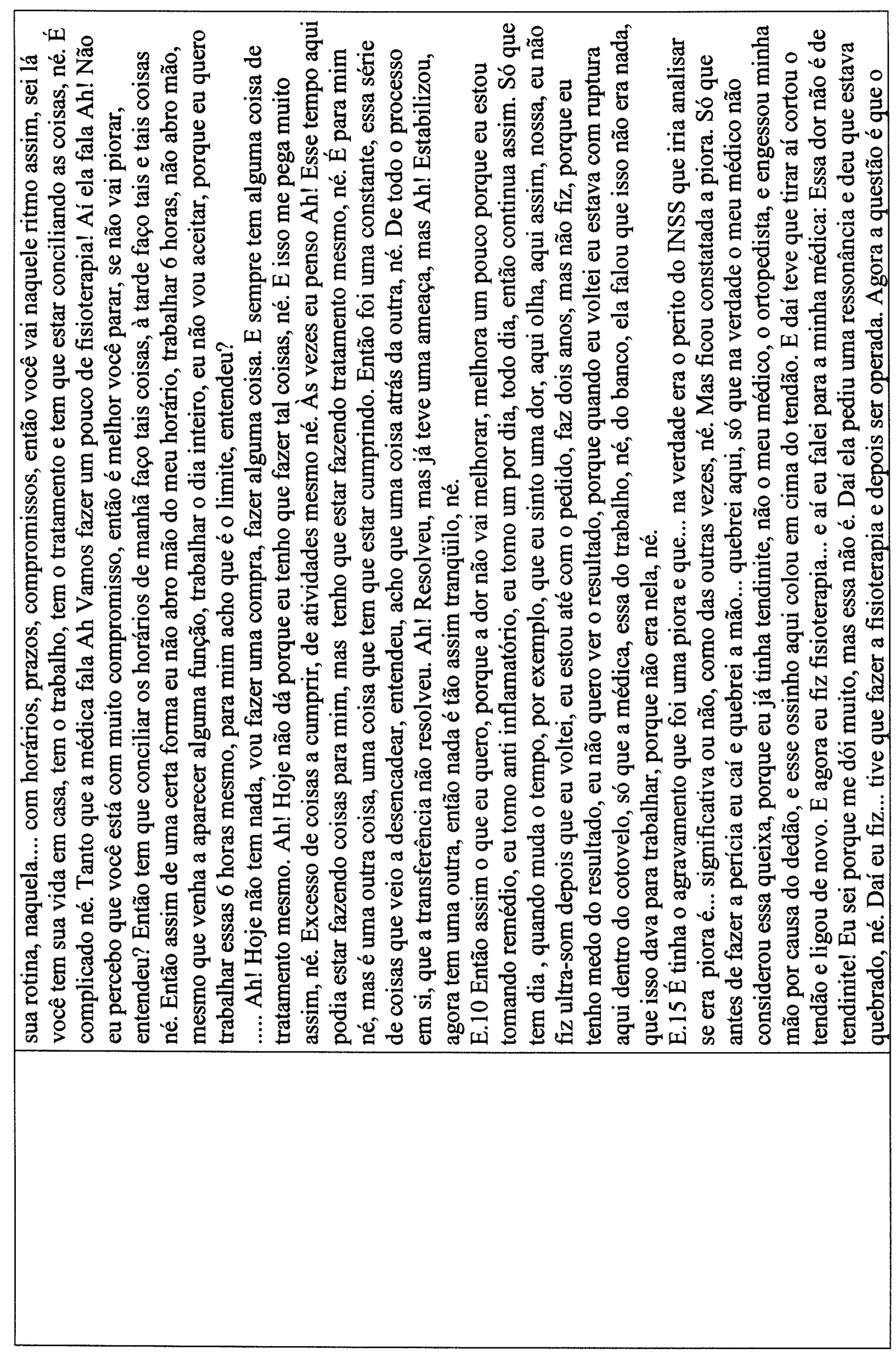



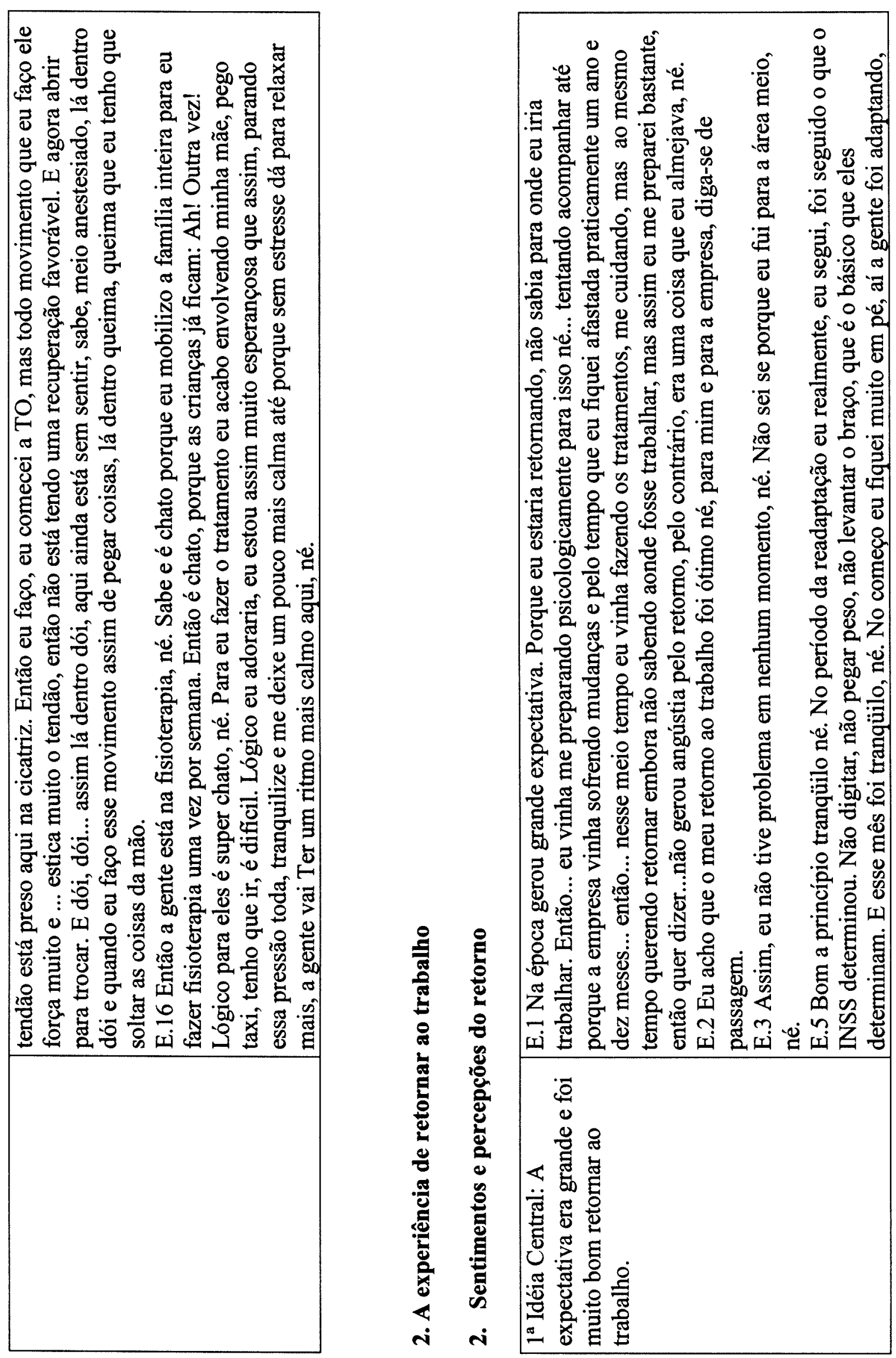


\begin{tabular}{|c|c|}
\hline \multirow[t]{2}{*}{ 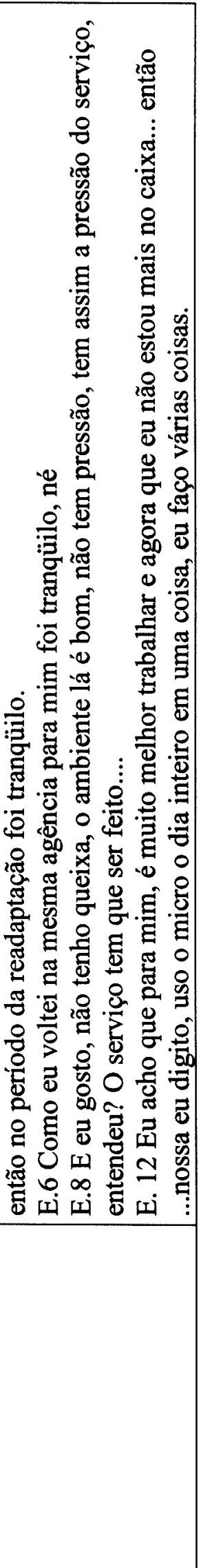 } & 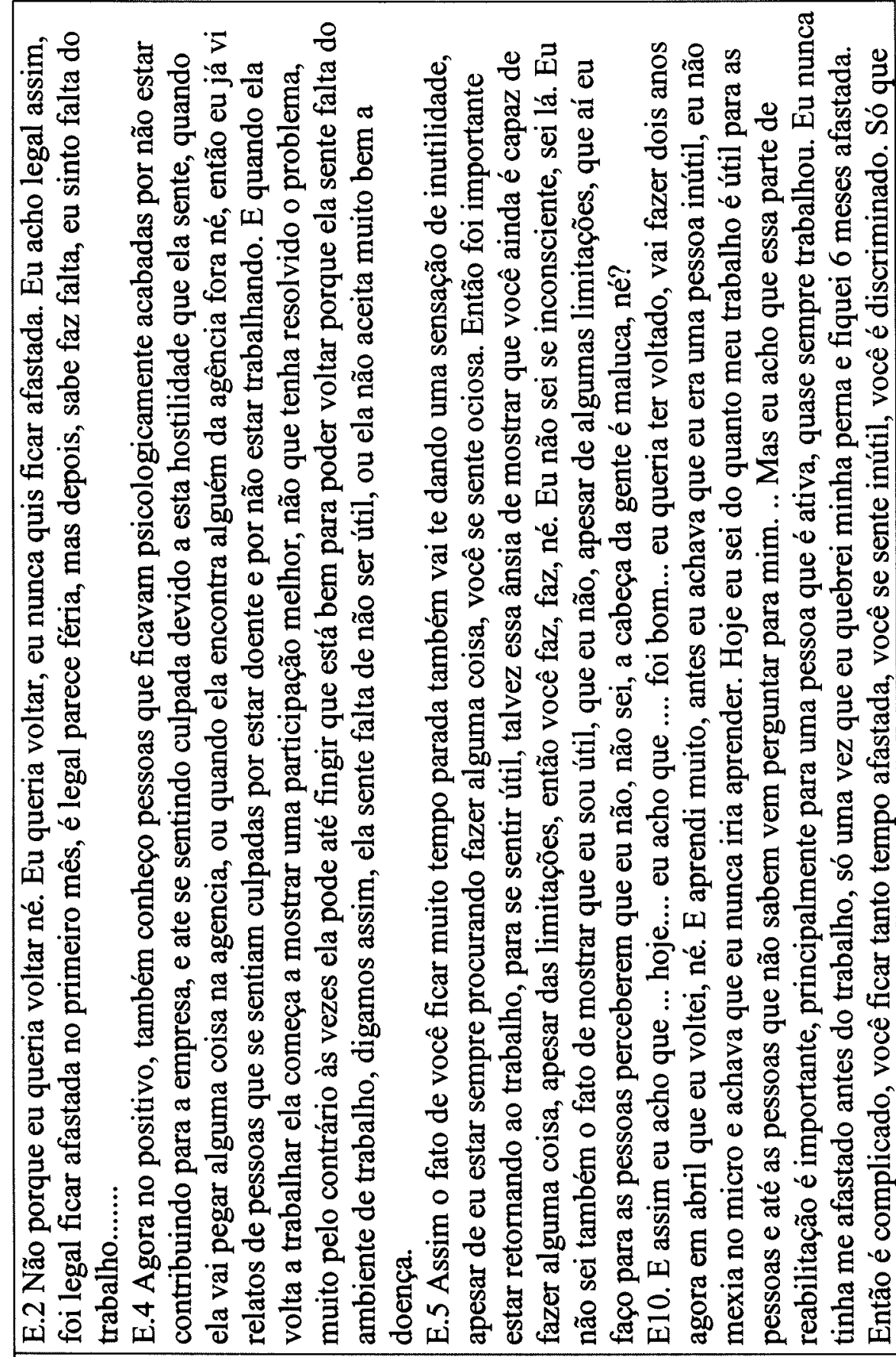 \\
\hline & 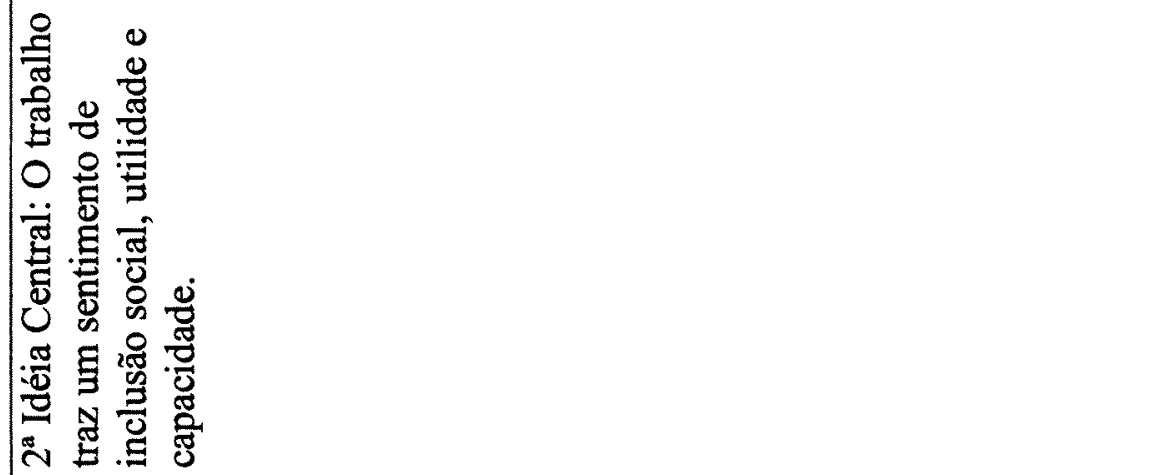 \\
\hline
\end{tabular}




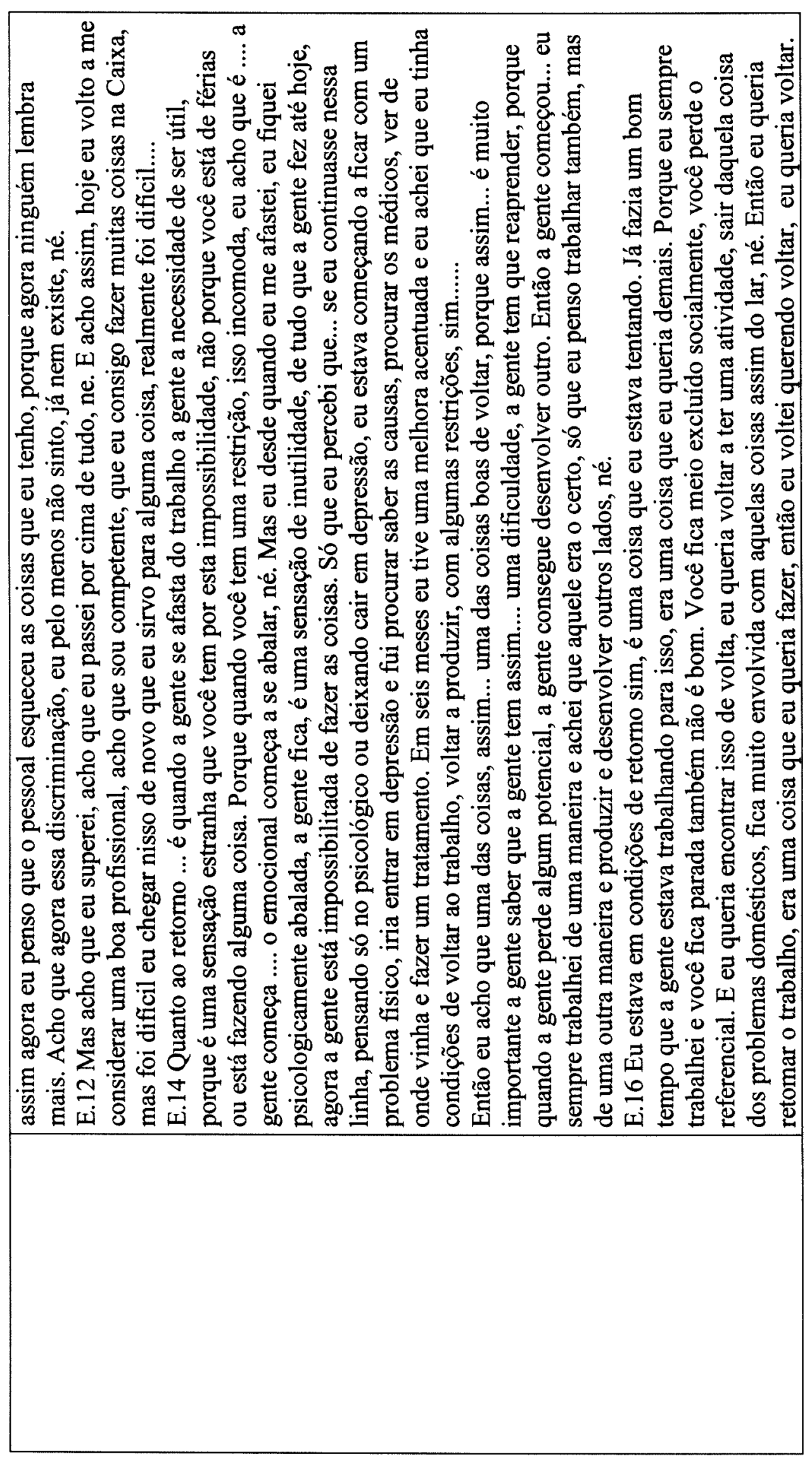




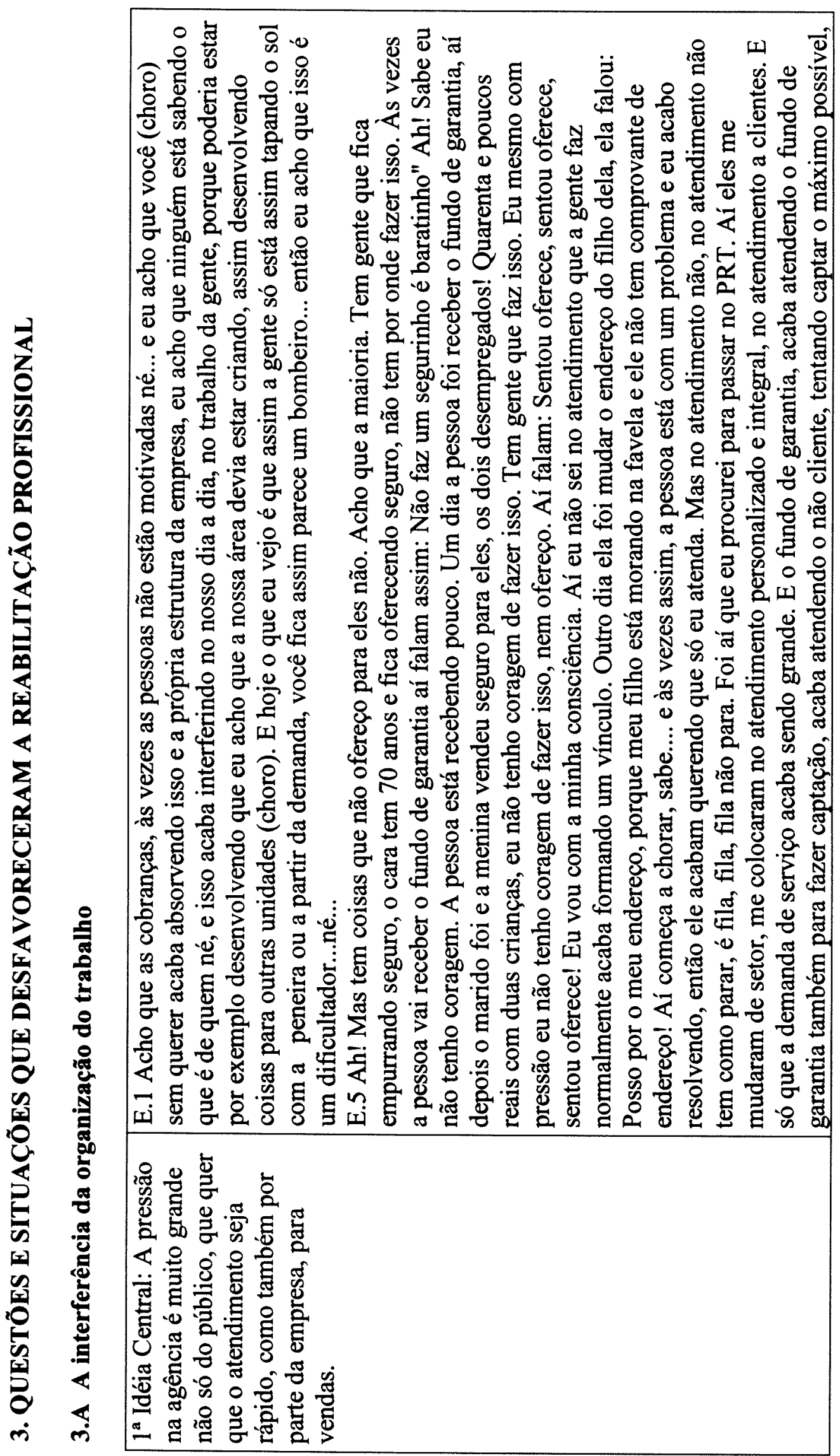




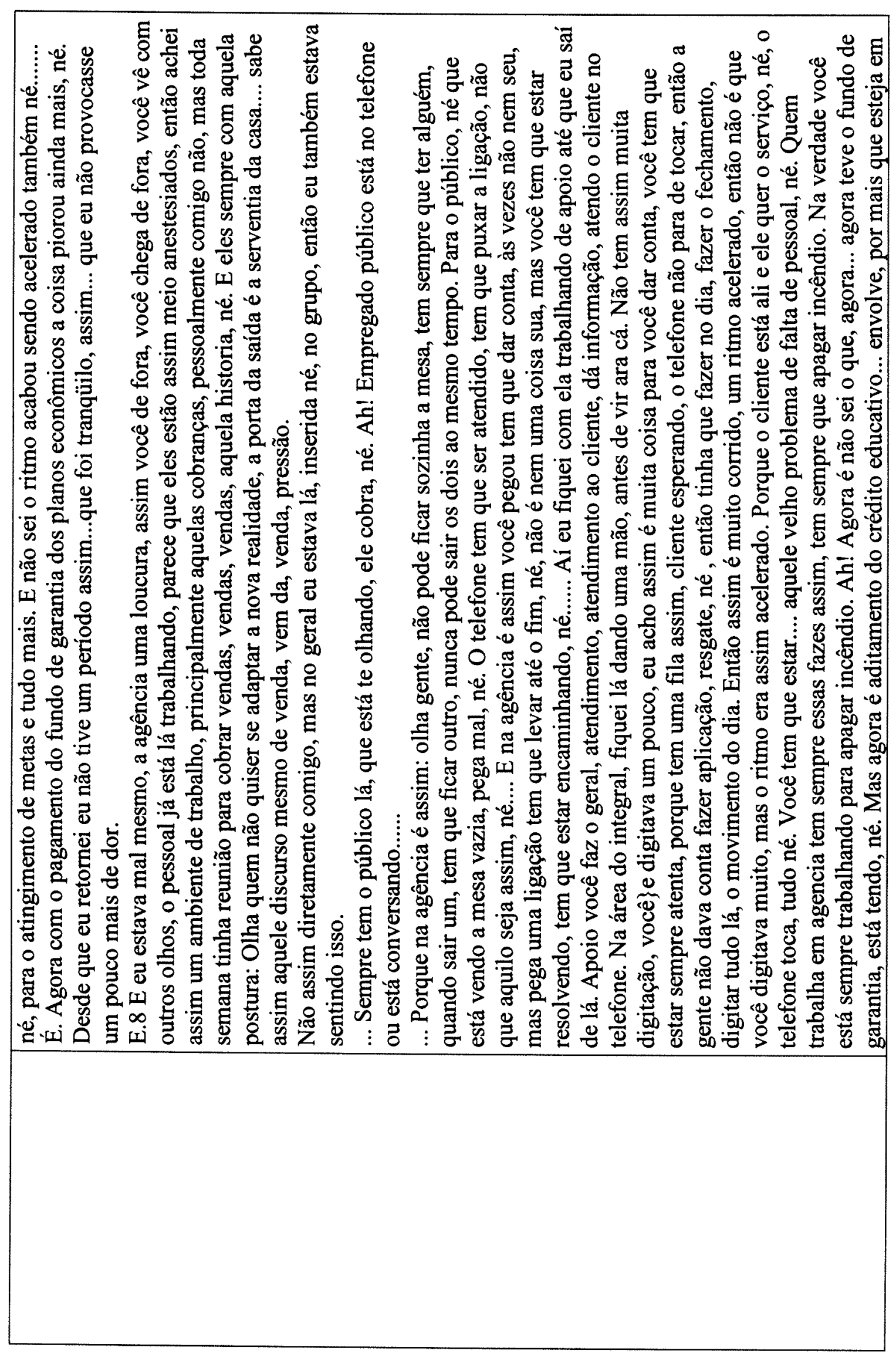




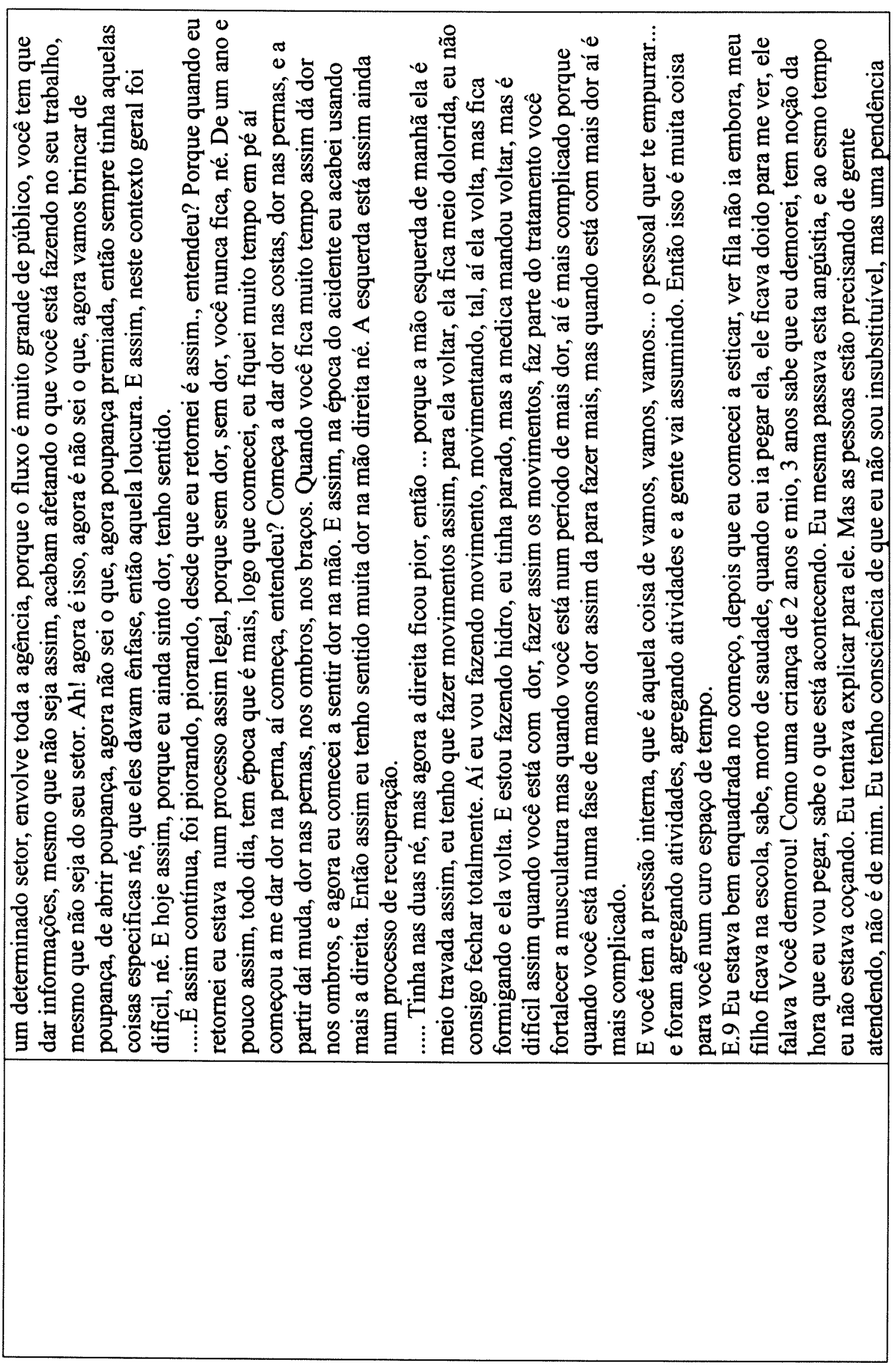




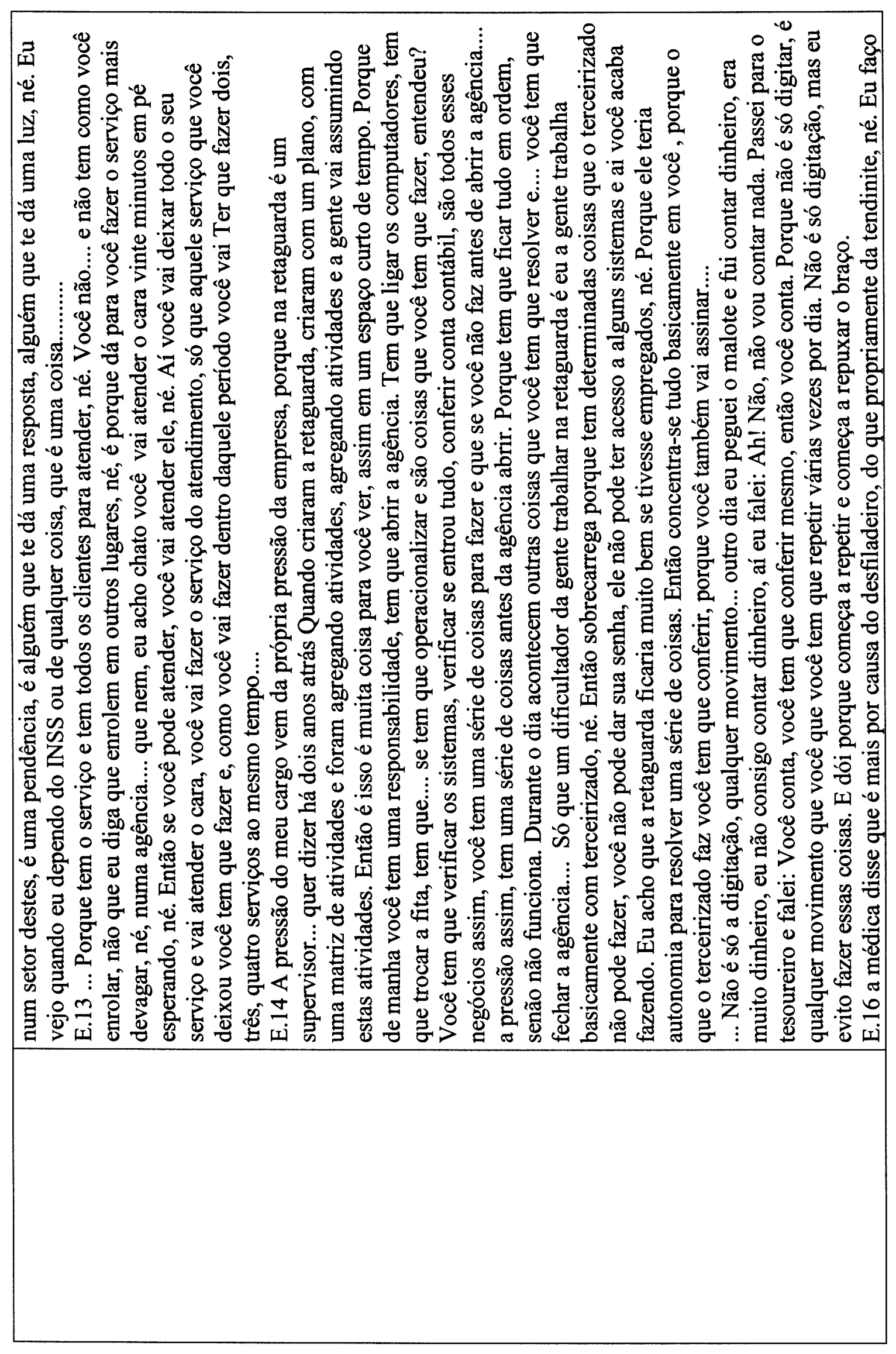




\begin{tabular}{|c|c|}
\hline \multirow[t]{2}{*}{ 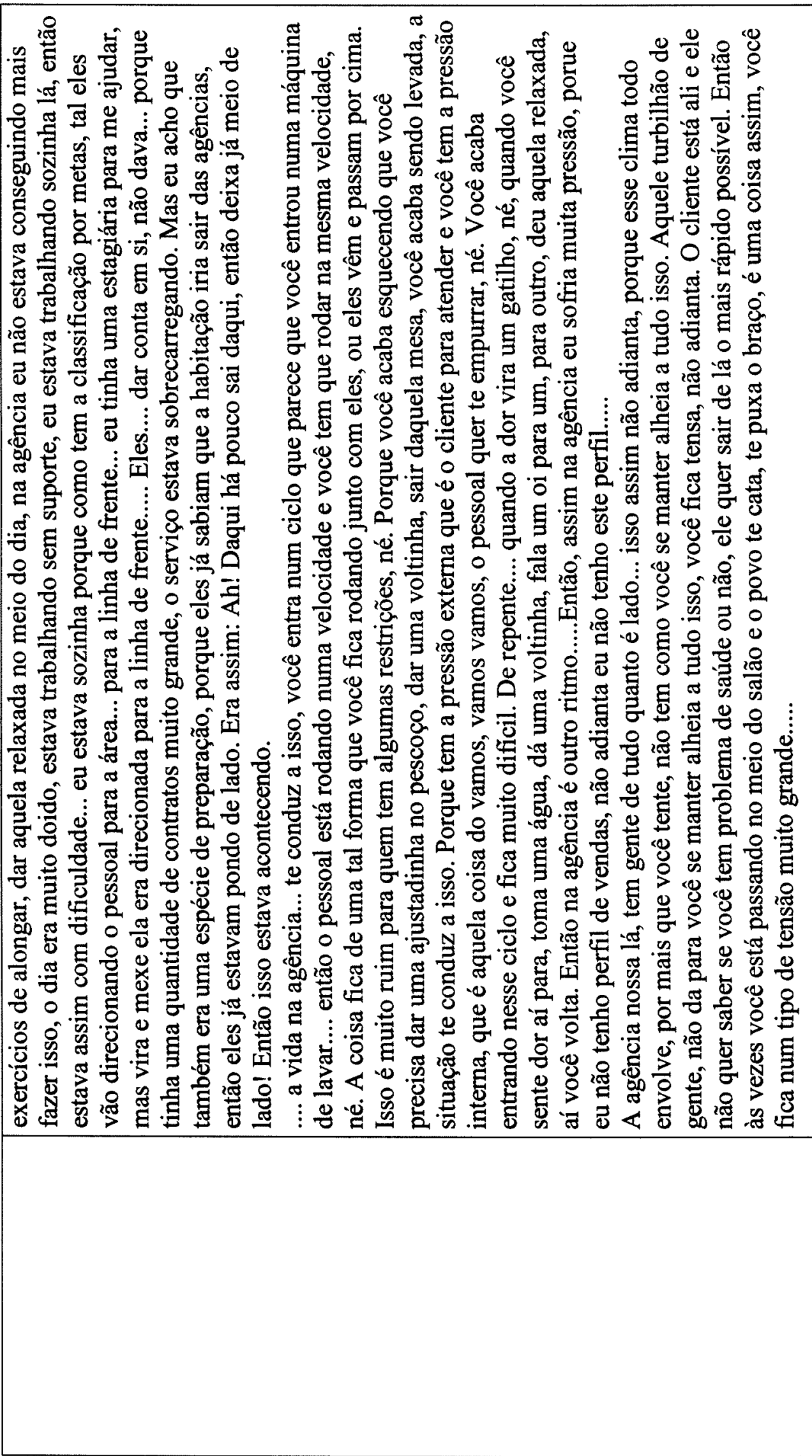 } & 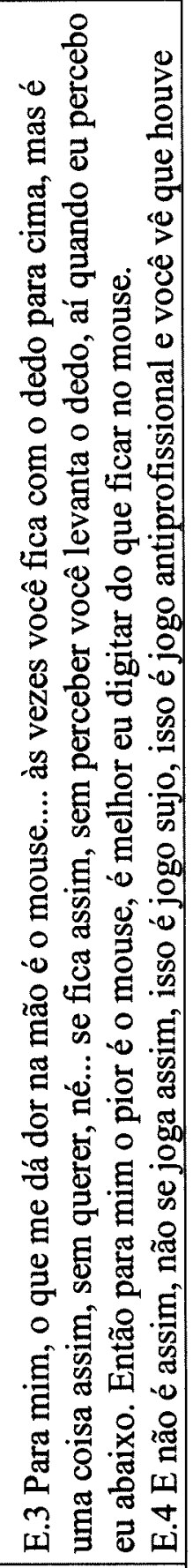 \\
\hline & 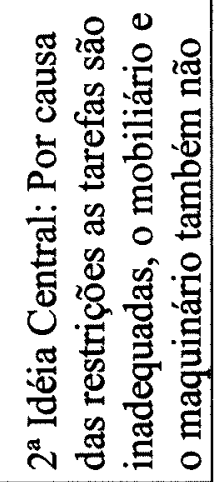 \\
\hline
\end{tabular}




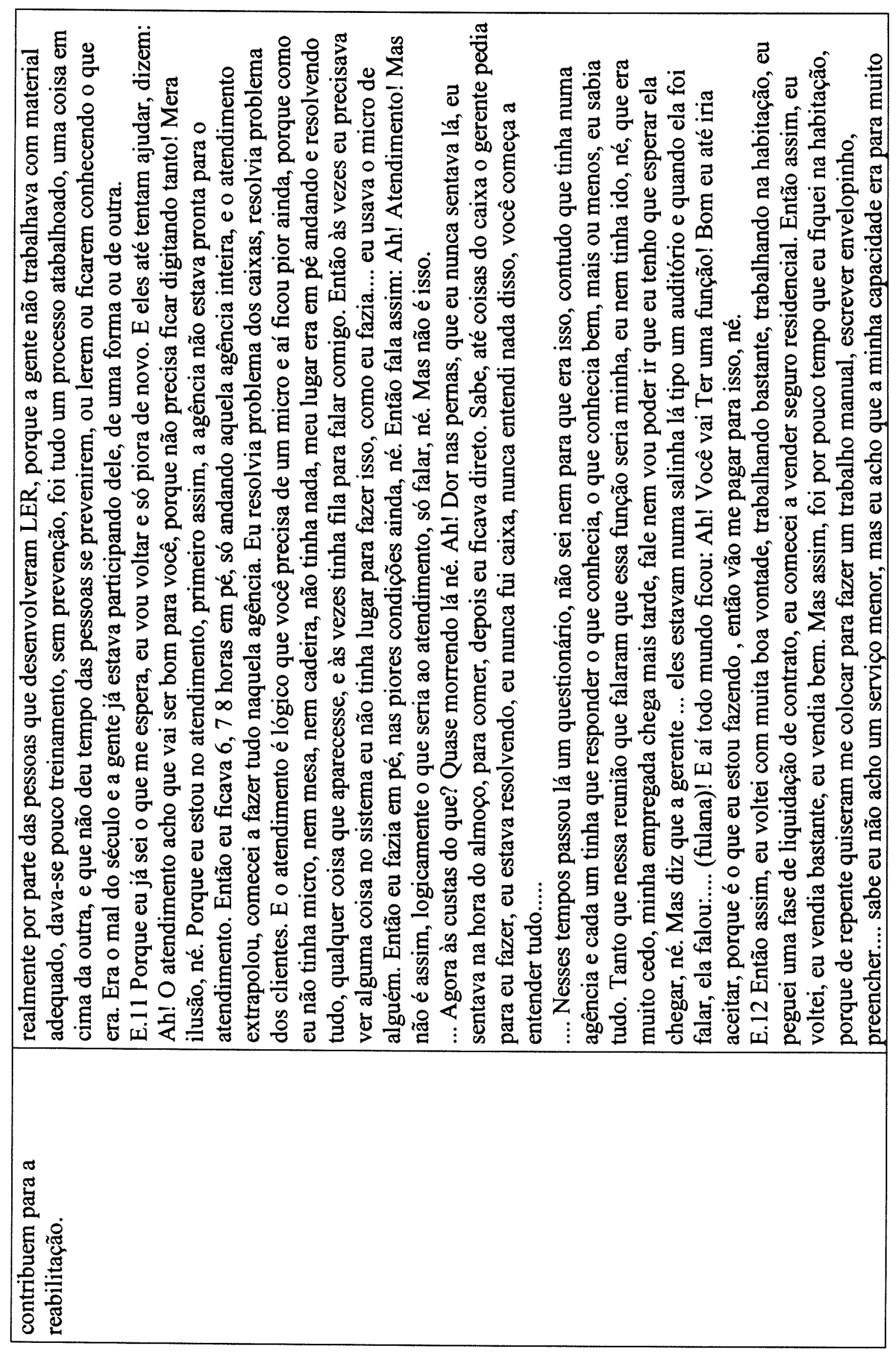




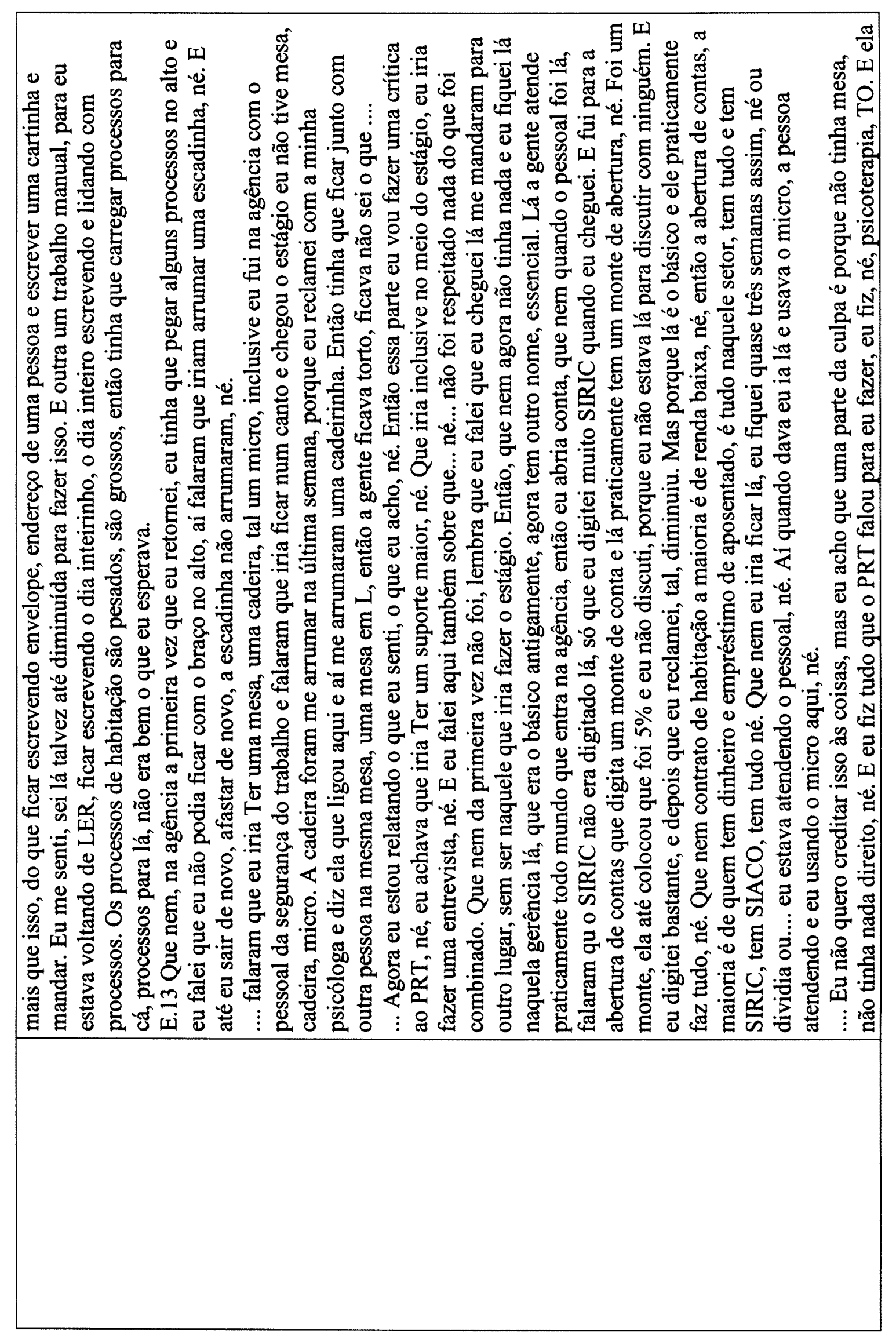




\begin{tabular}{|c|c|}
\hline 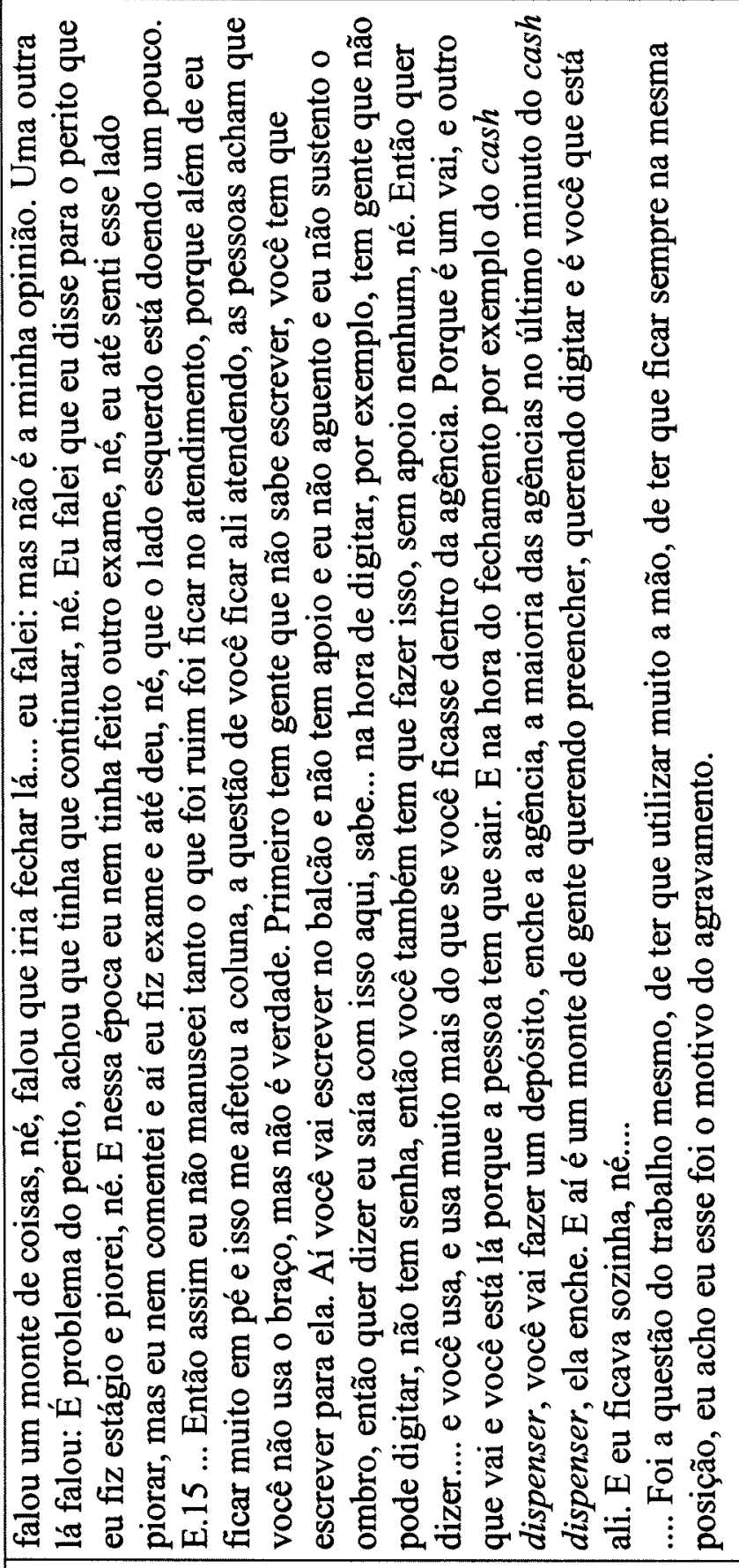 & 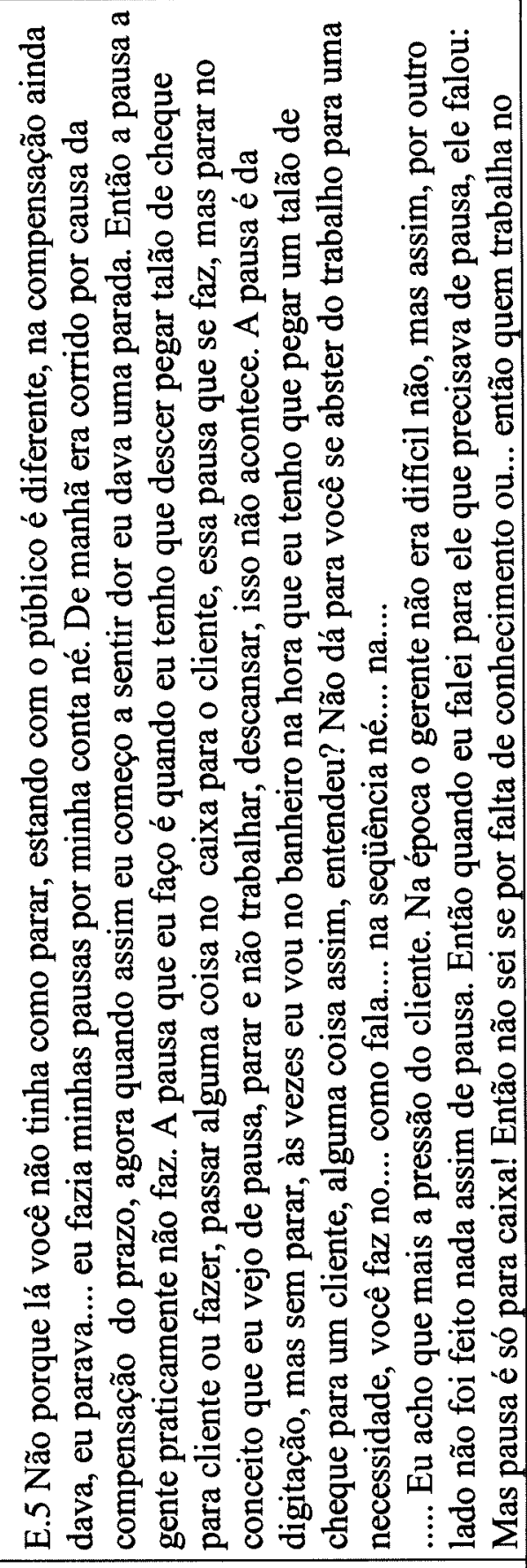 \\
\hline & 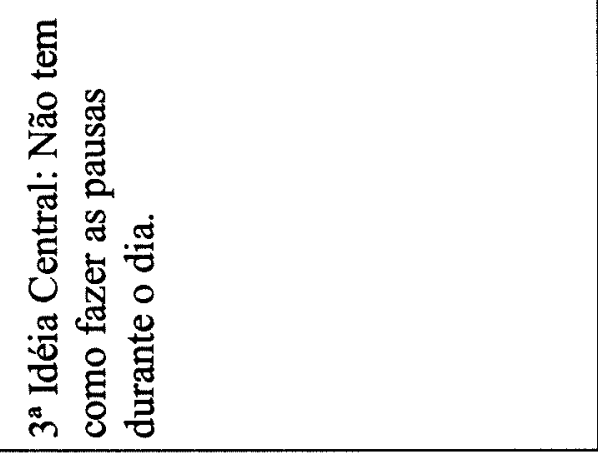 \\
\hline
\end{tabular}




\begin{tabular}{|c|c|c|c|}
\hline 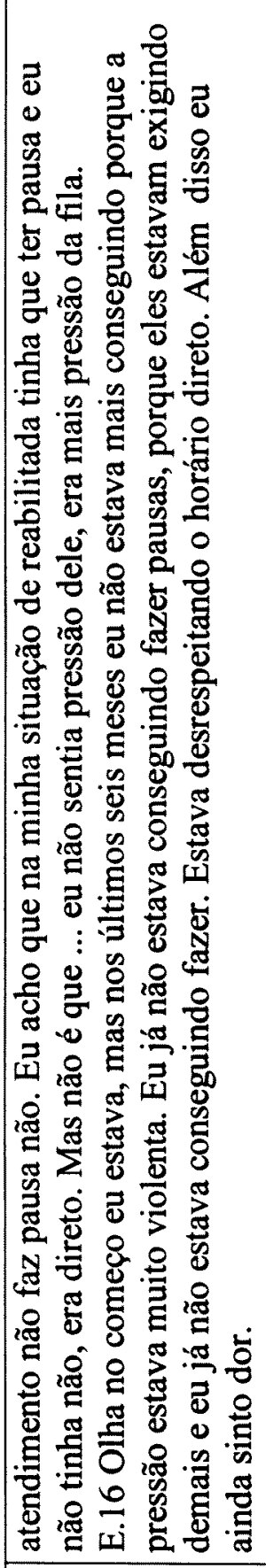 & 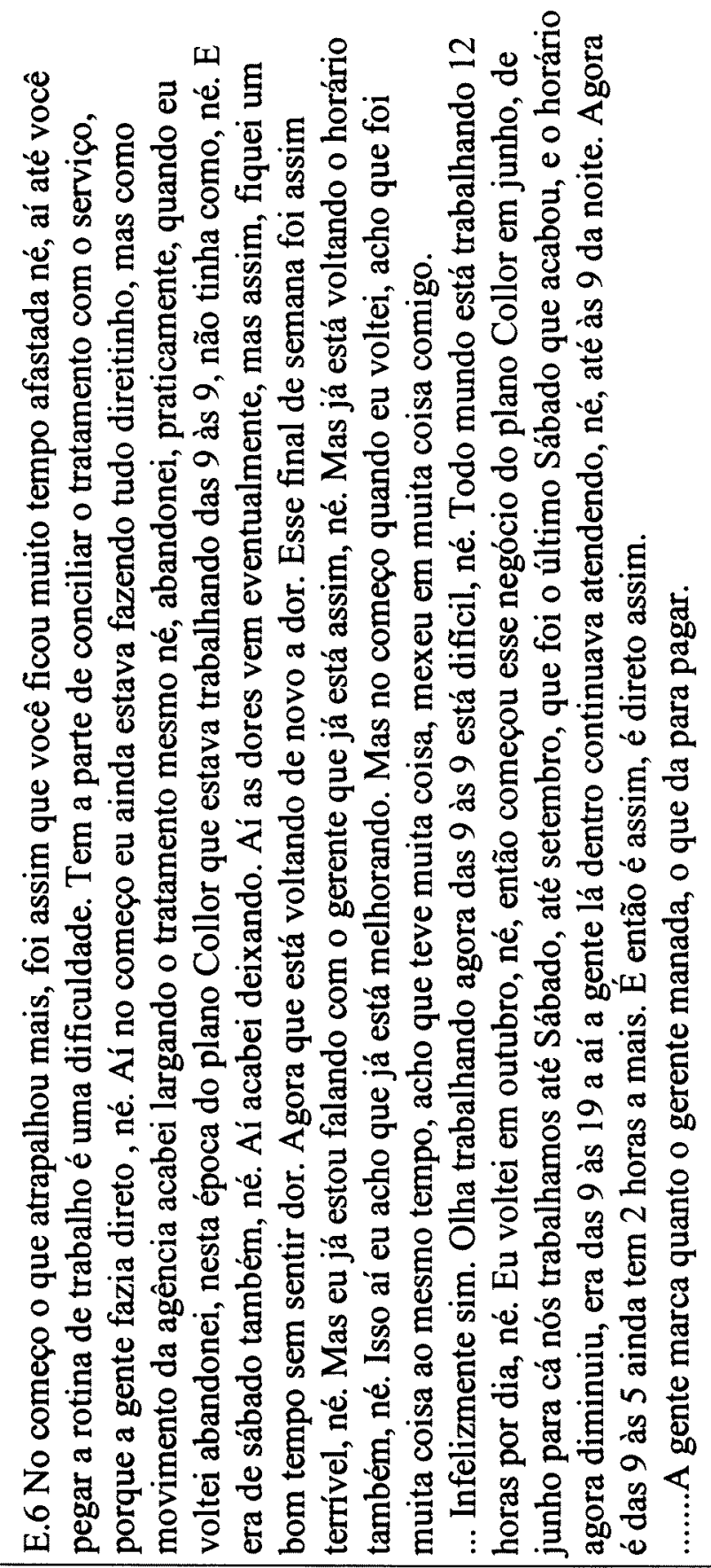 & 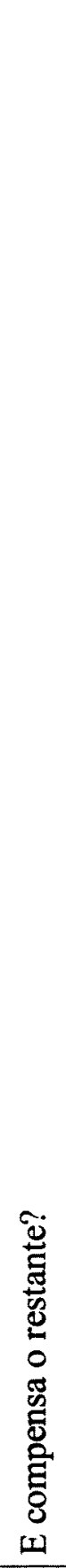 & 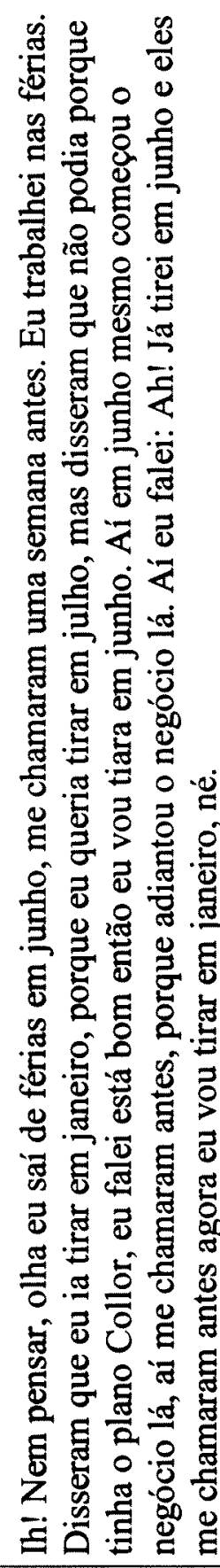 \\
\hline & 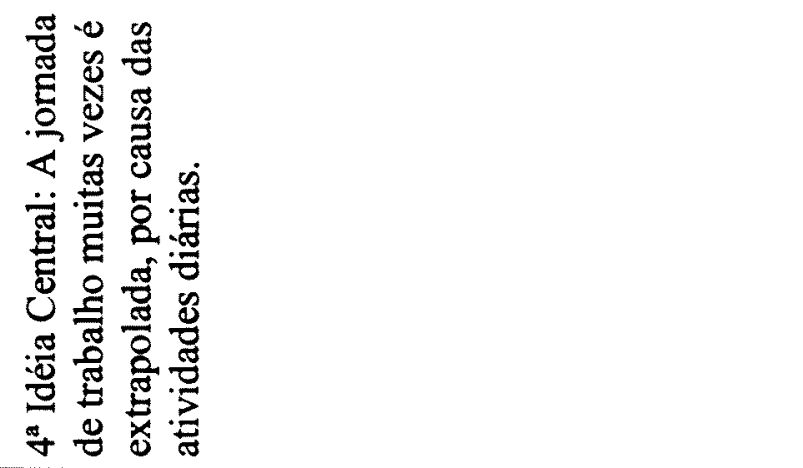 & & \\
\hline
\end{tabular}




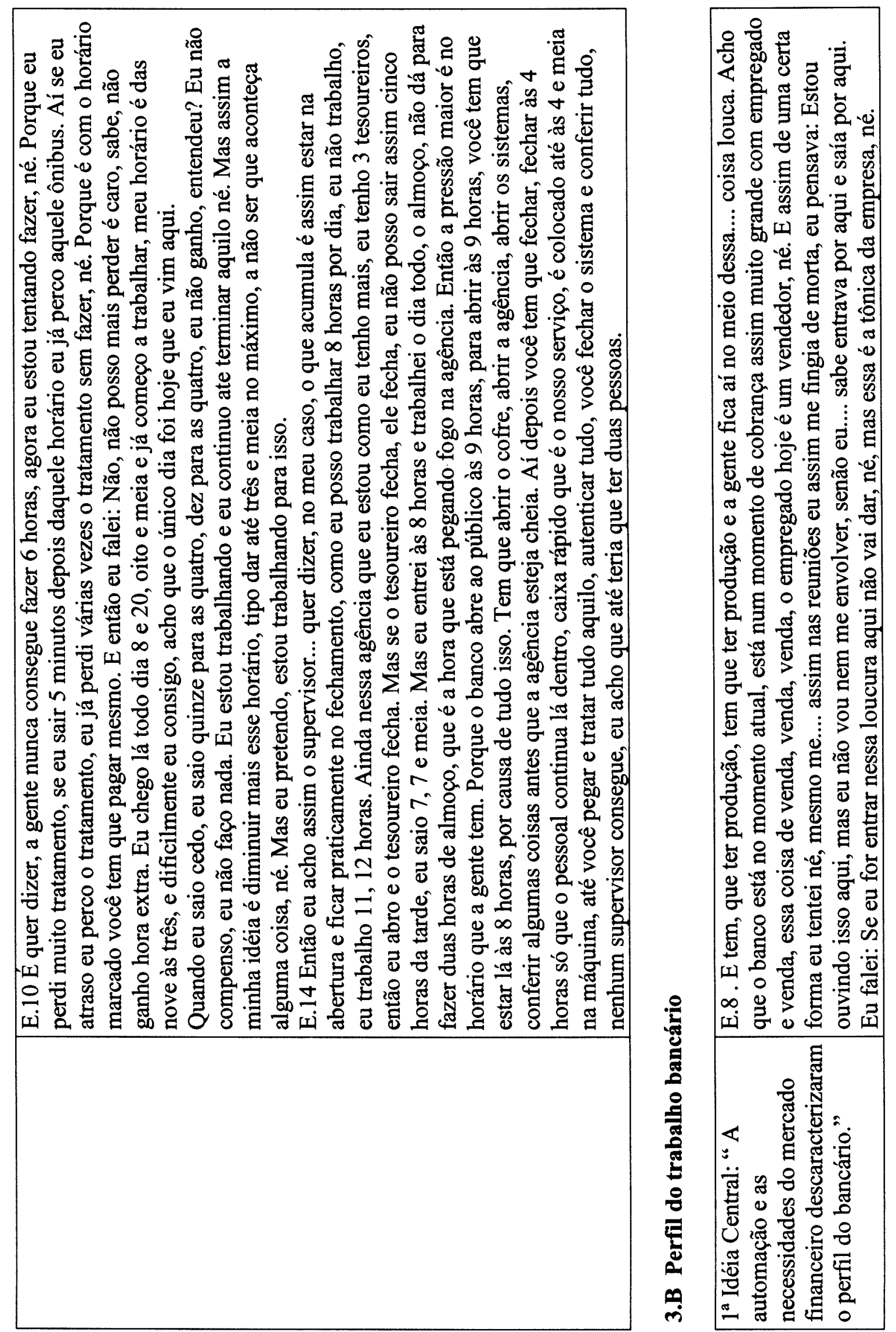




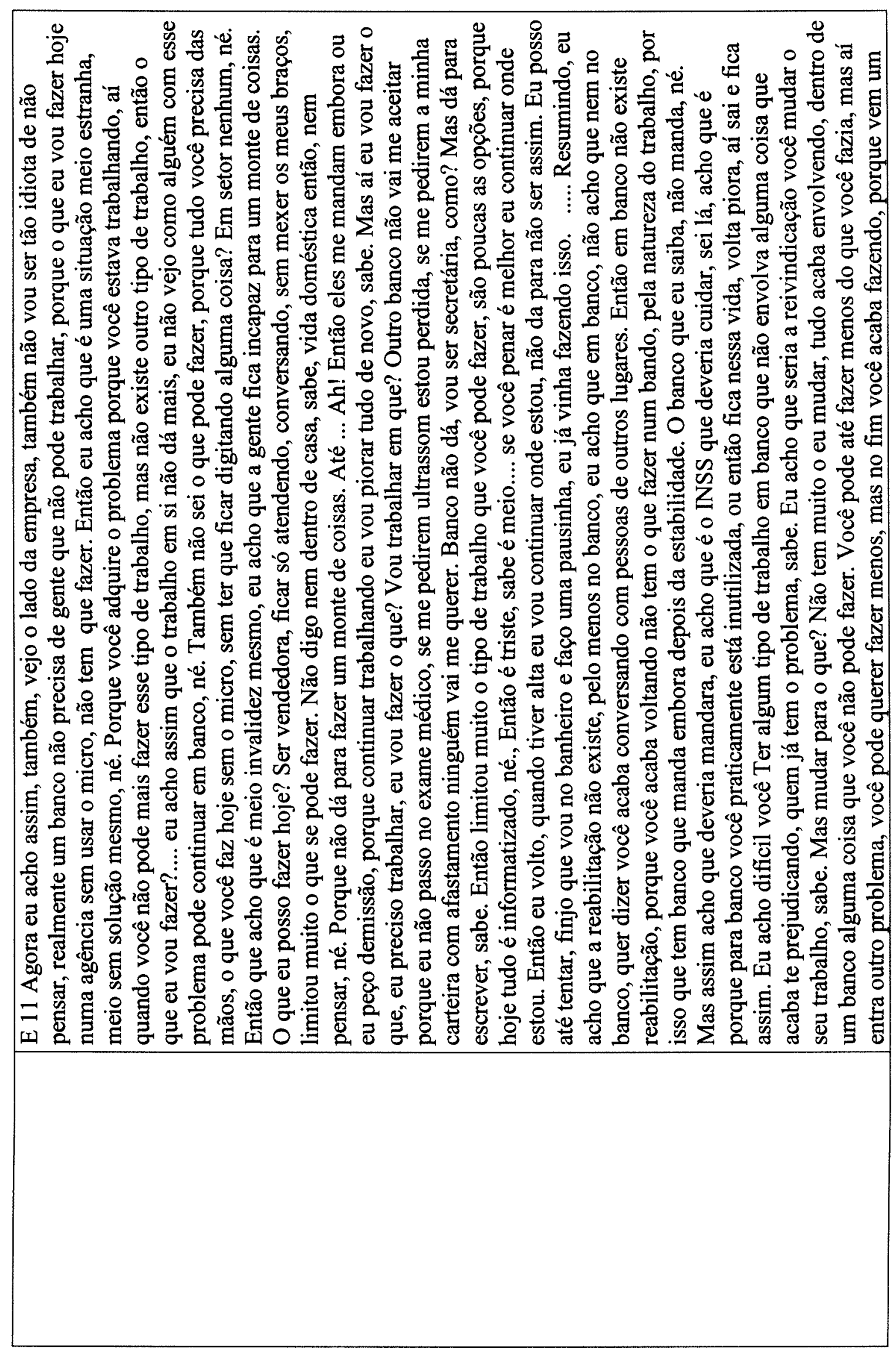




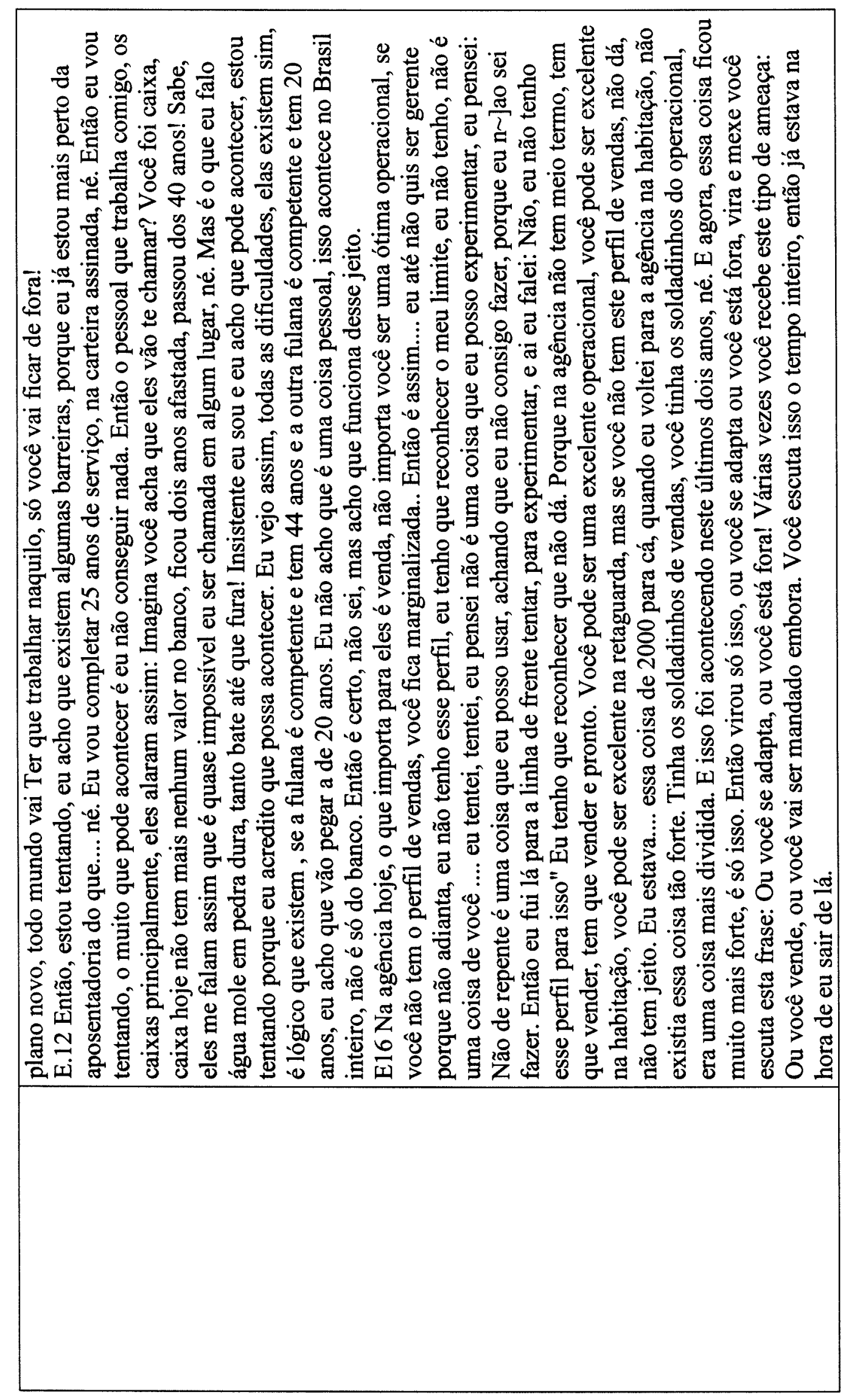




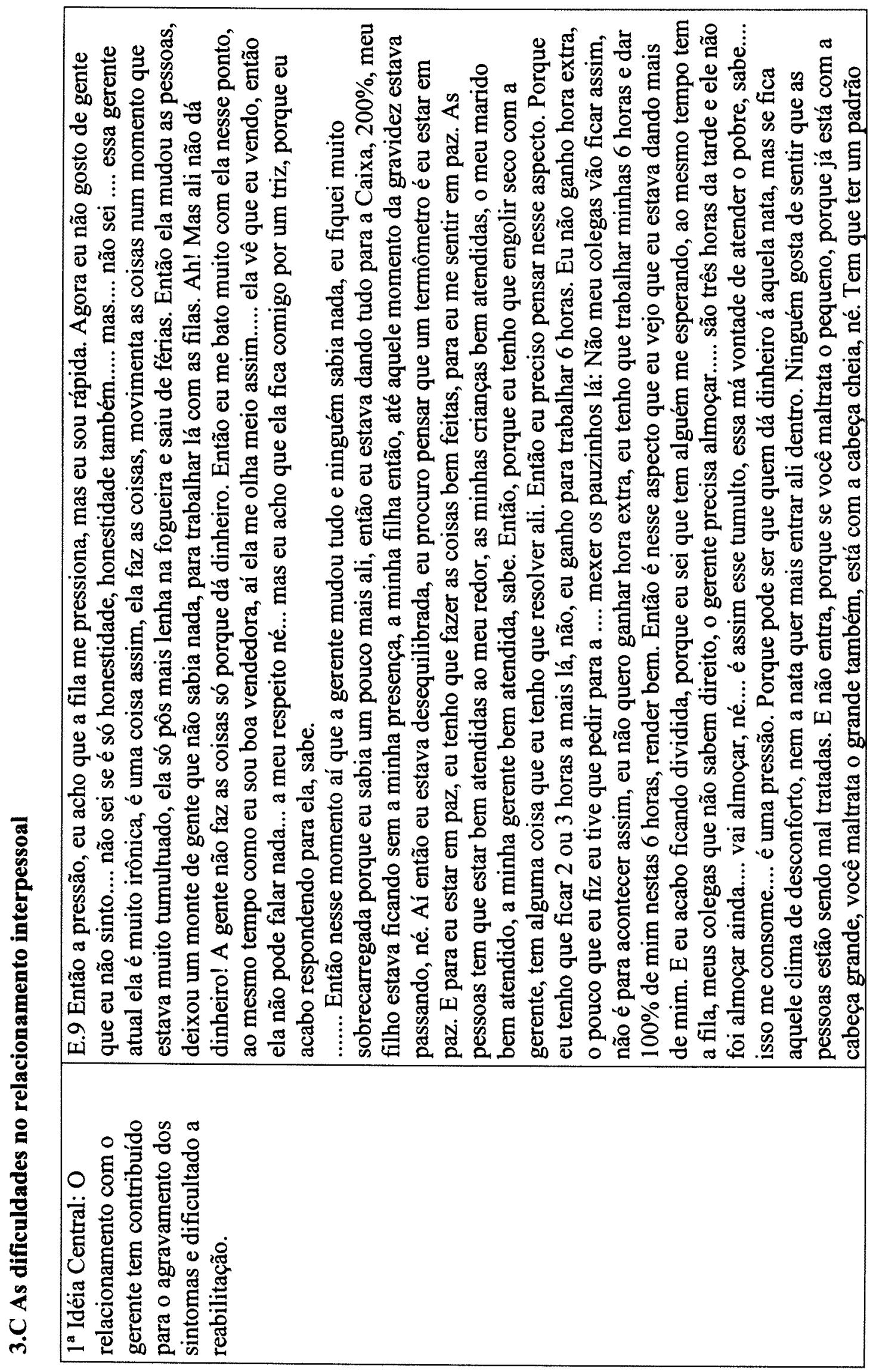




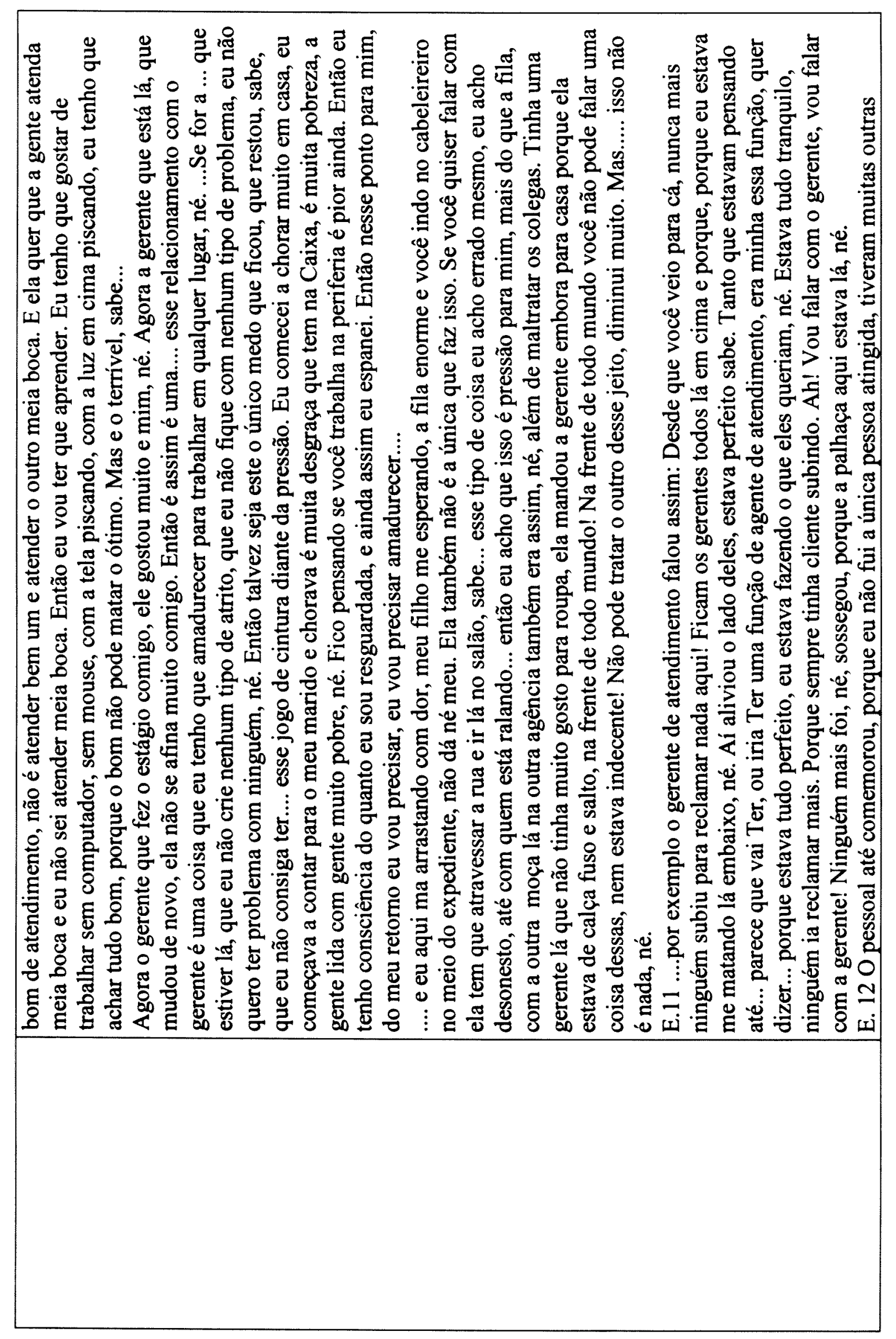




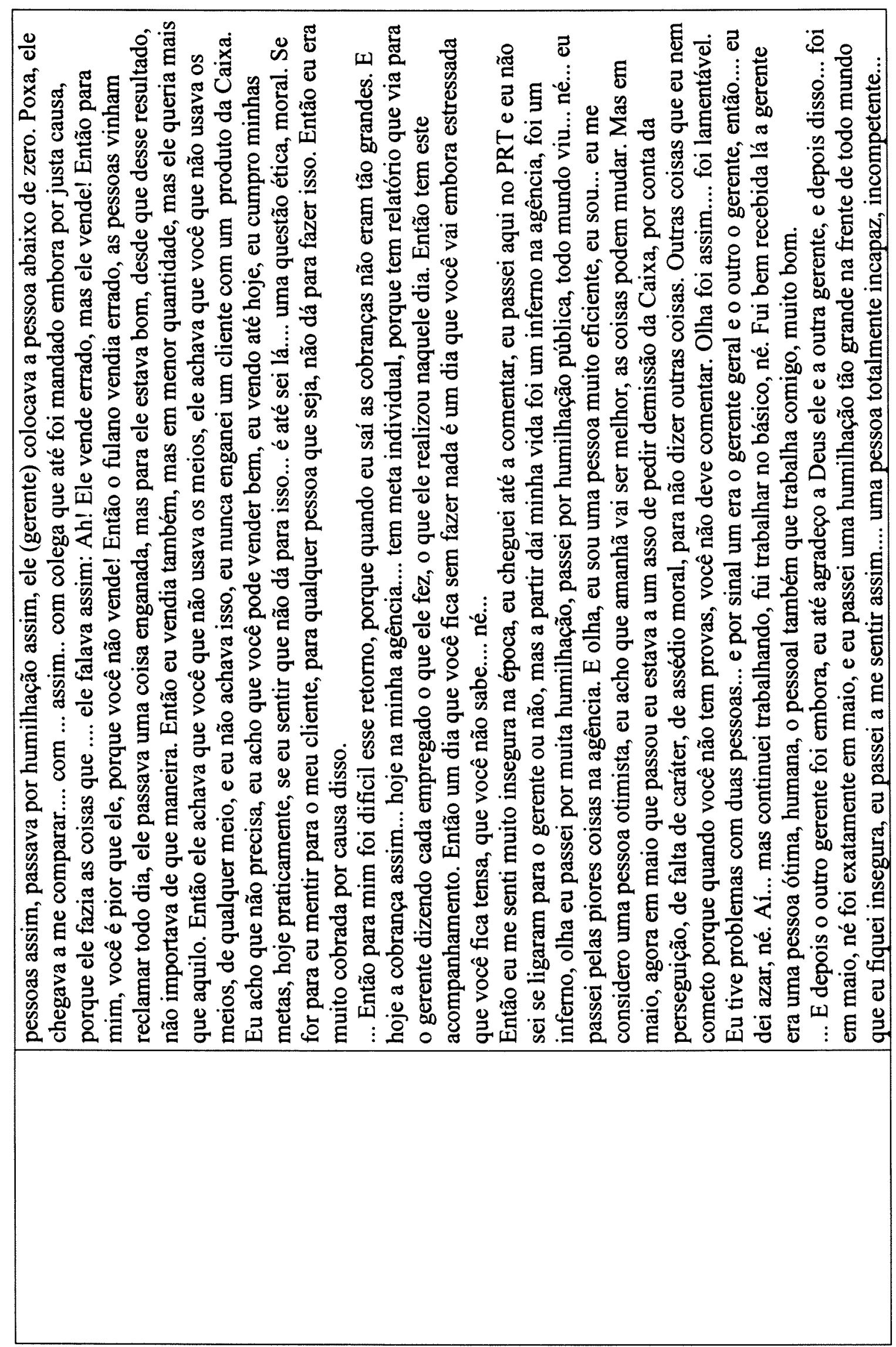




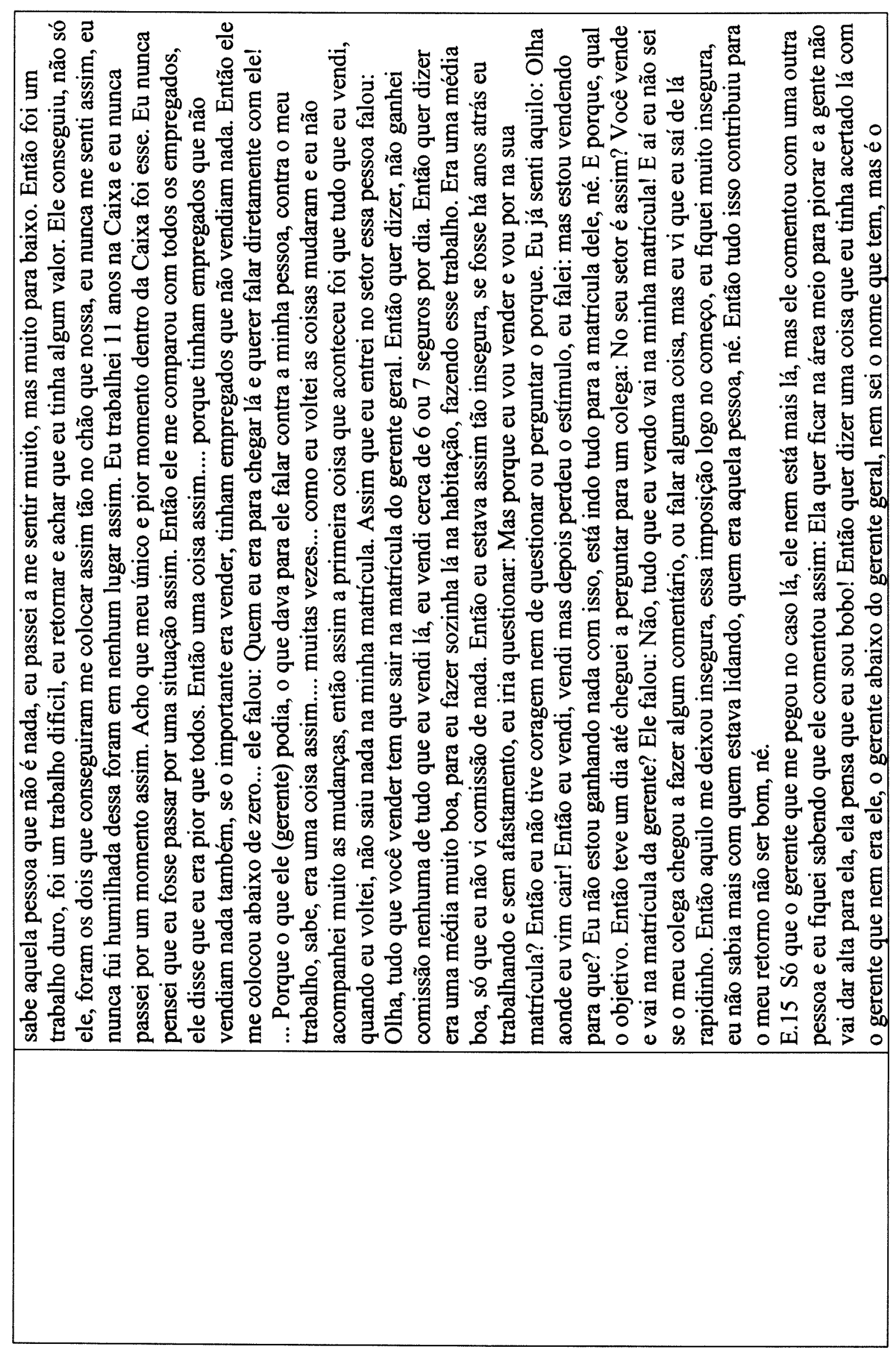




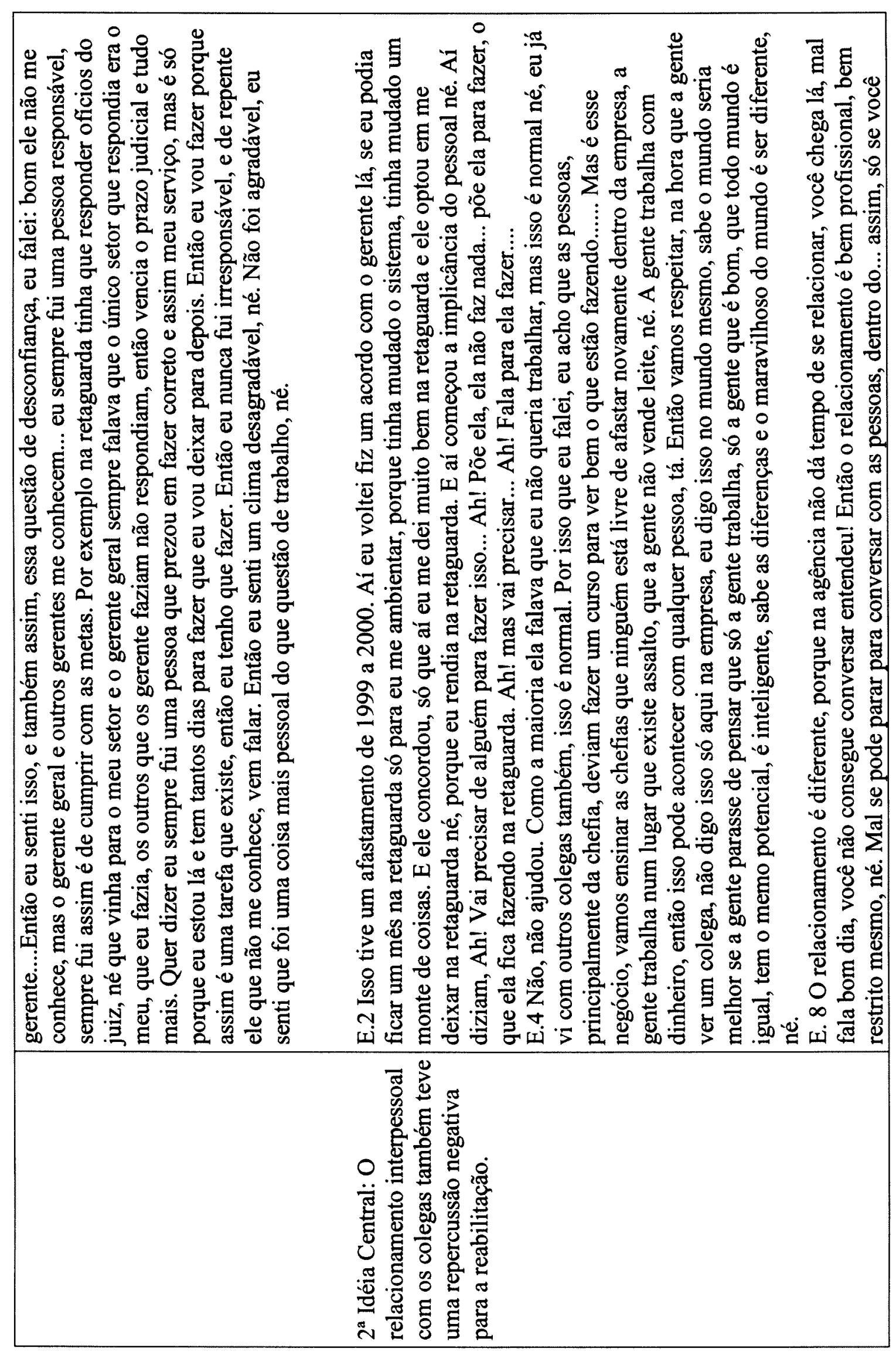




\begin{tabular}{|c|c|}
\hline 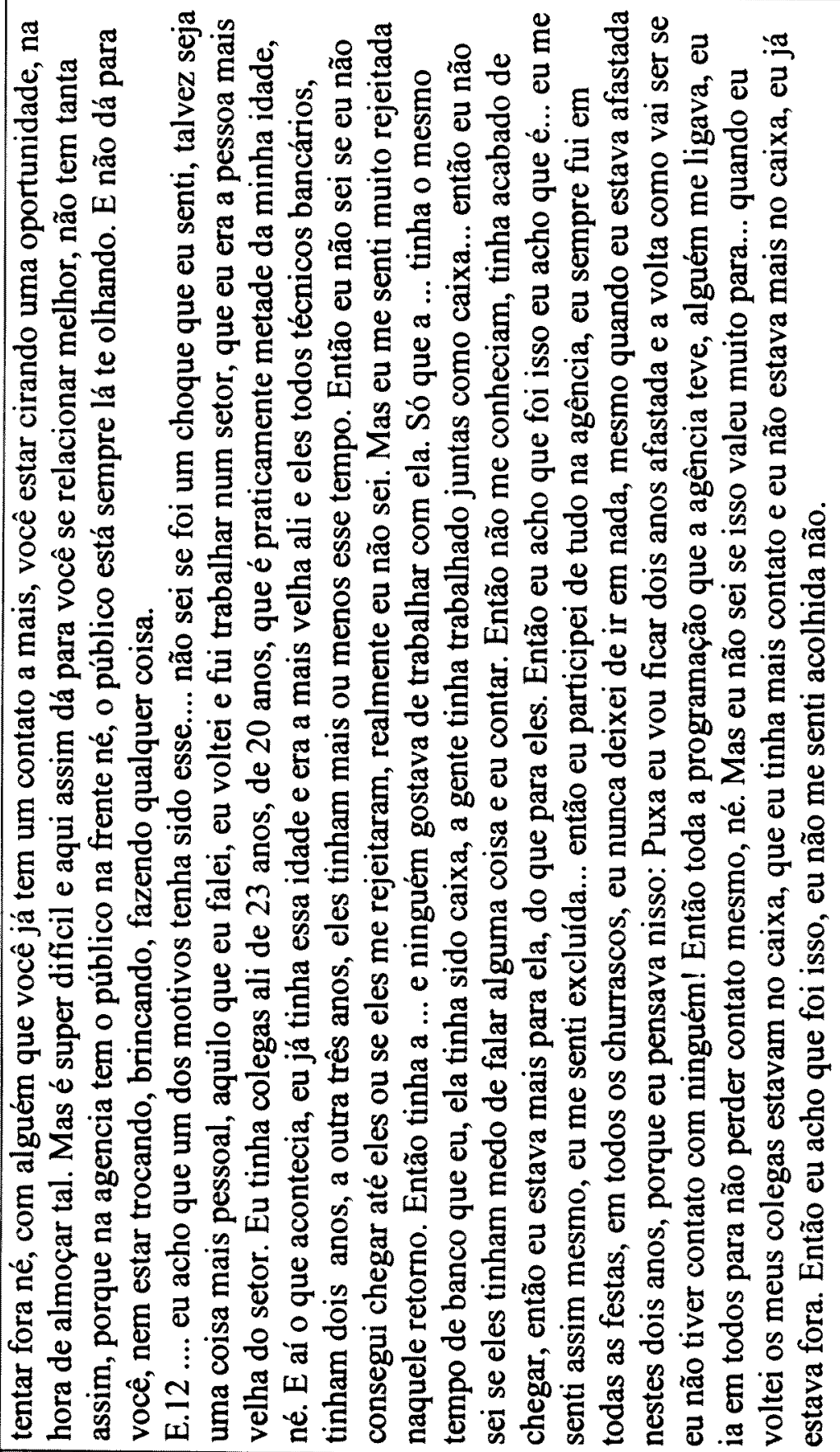 & 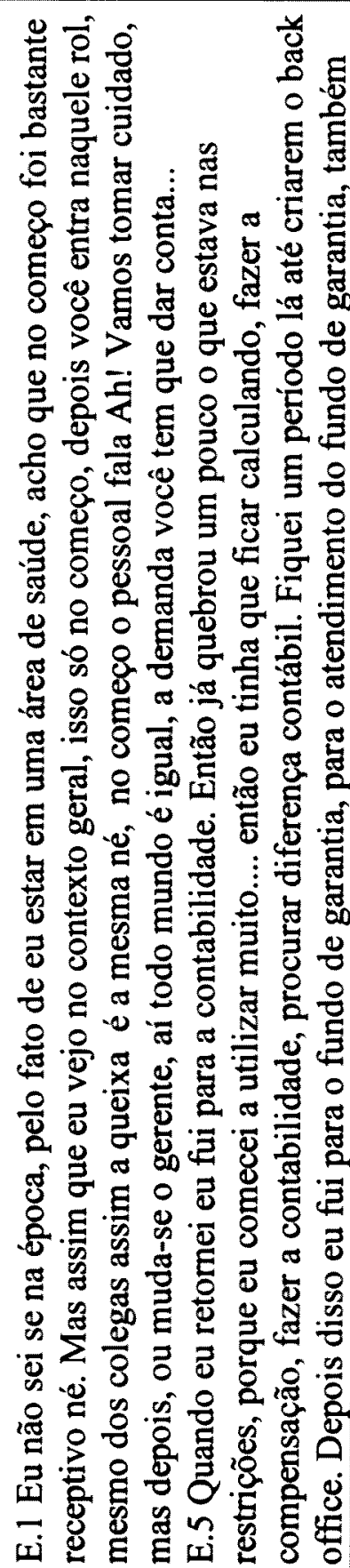 \\
\hline & 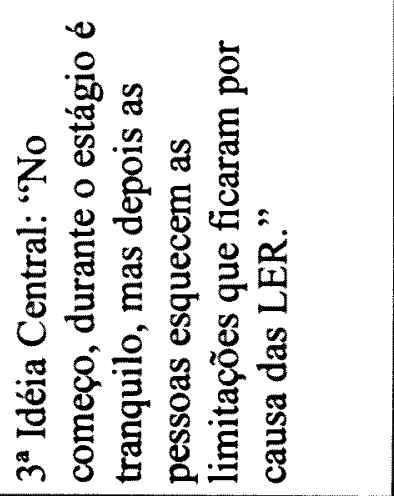 \\
\hline
\end{tabular}




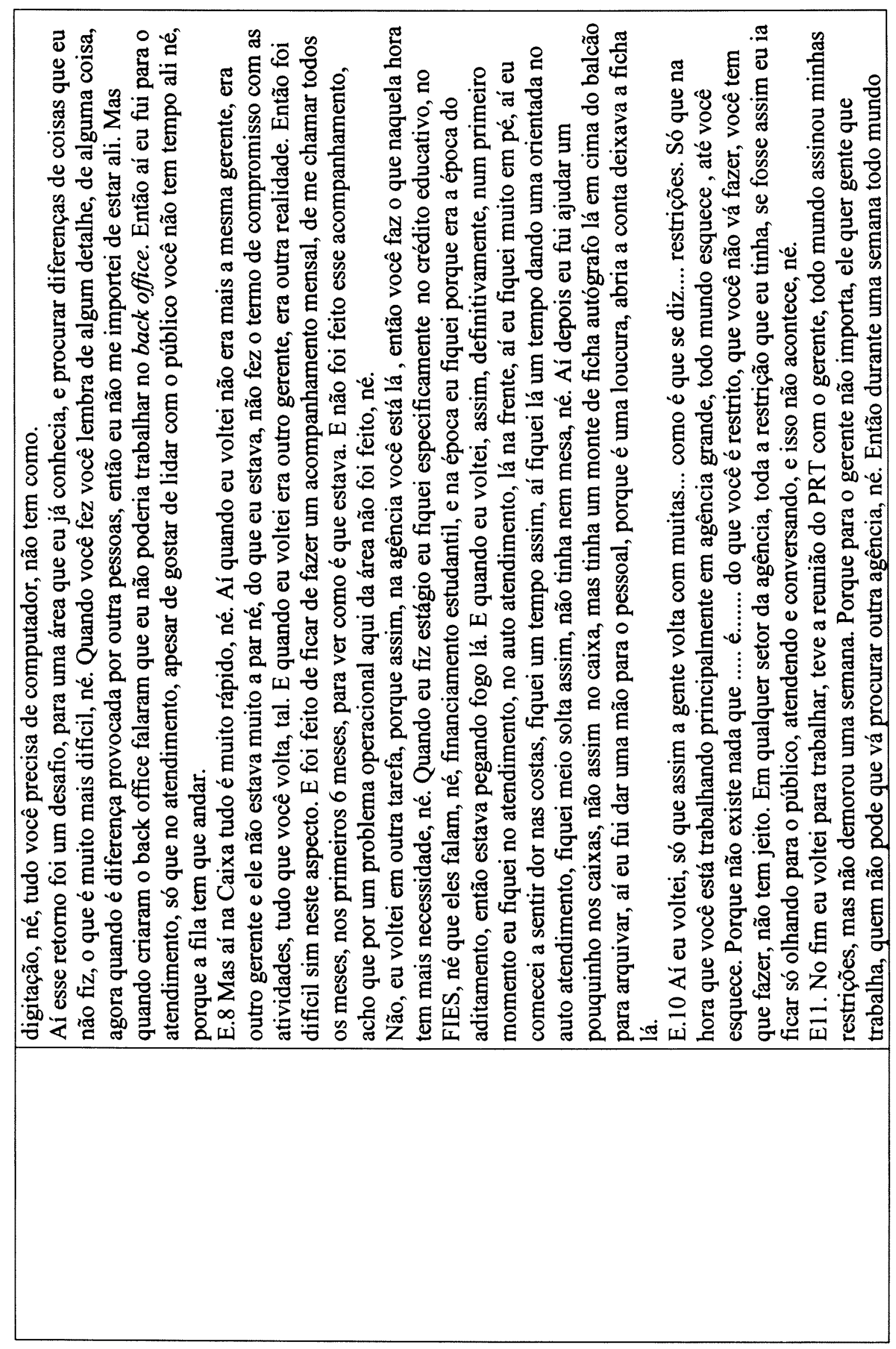




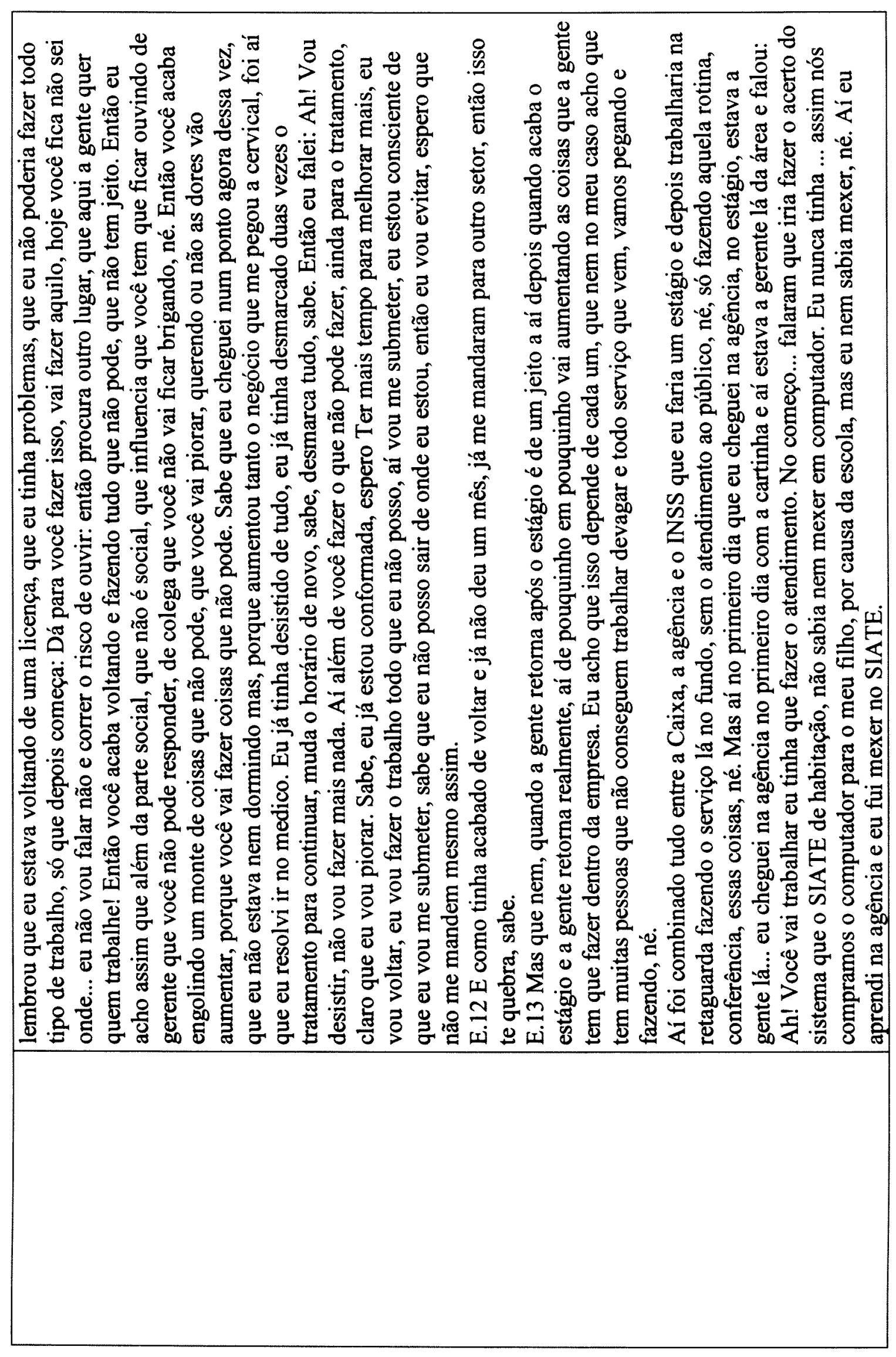




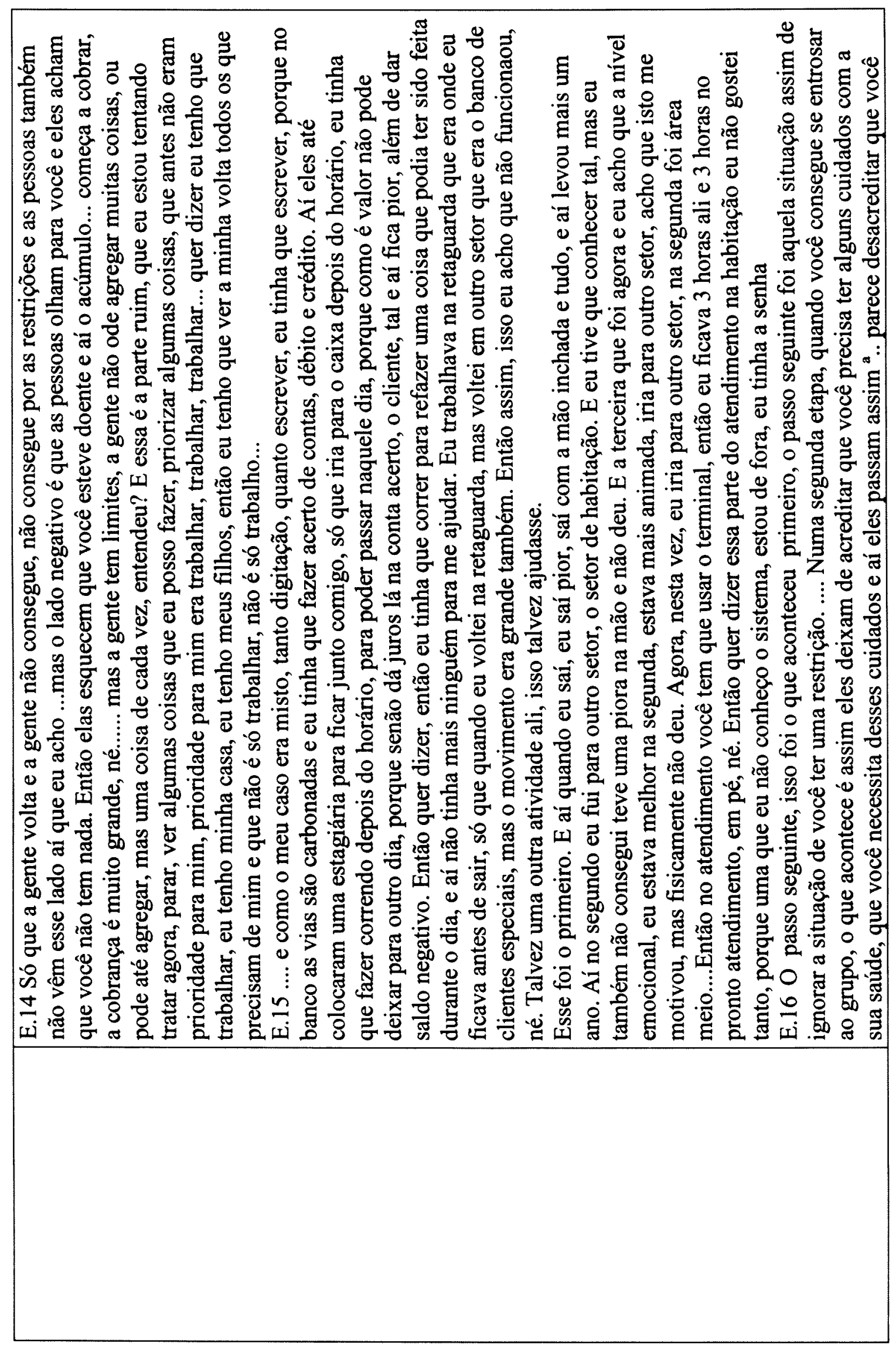



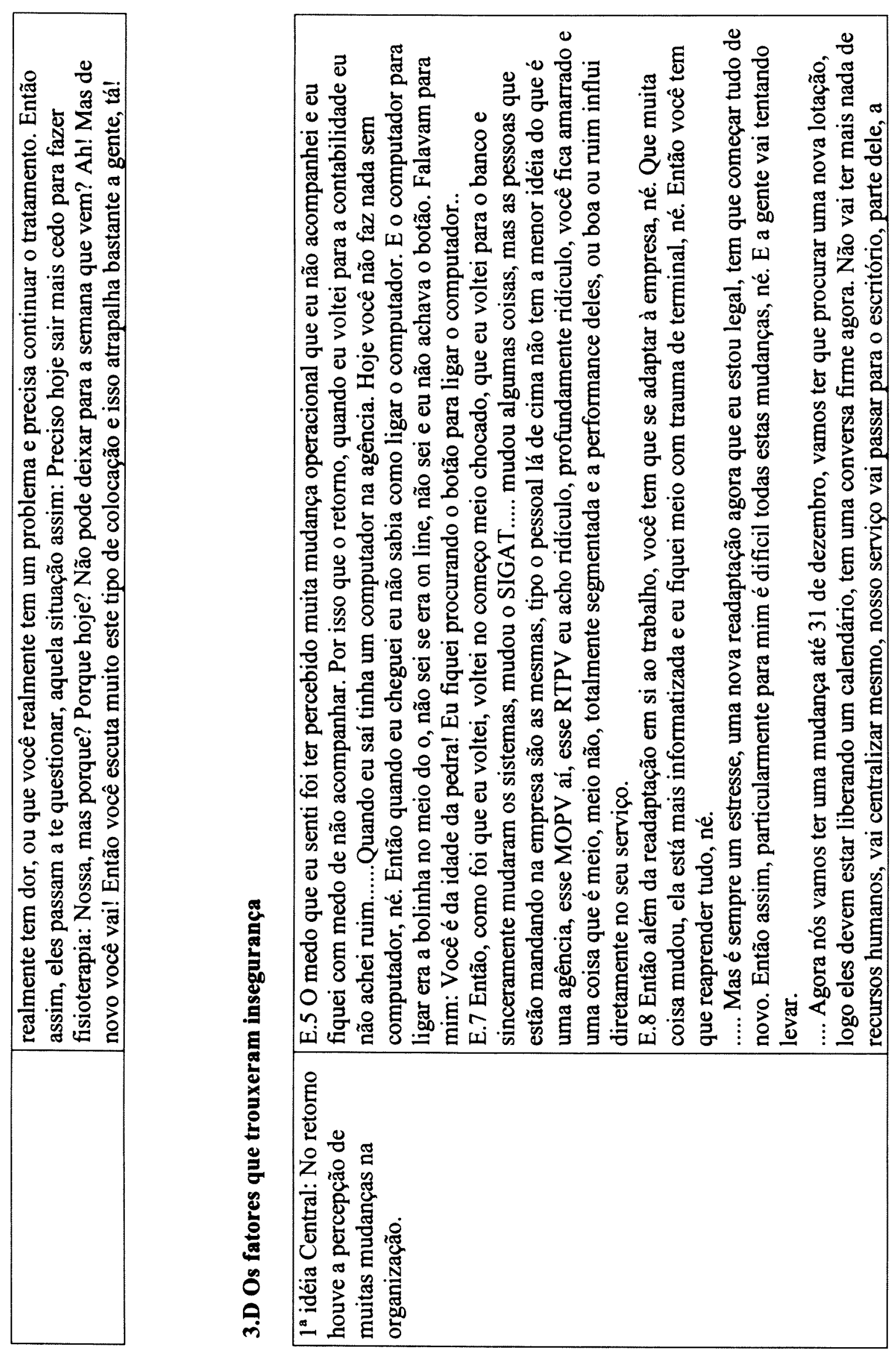


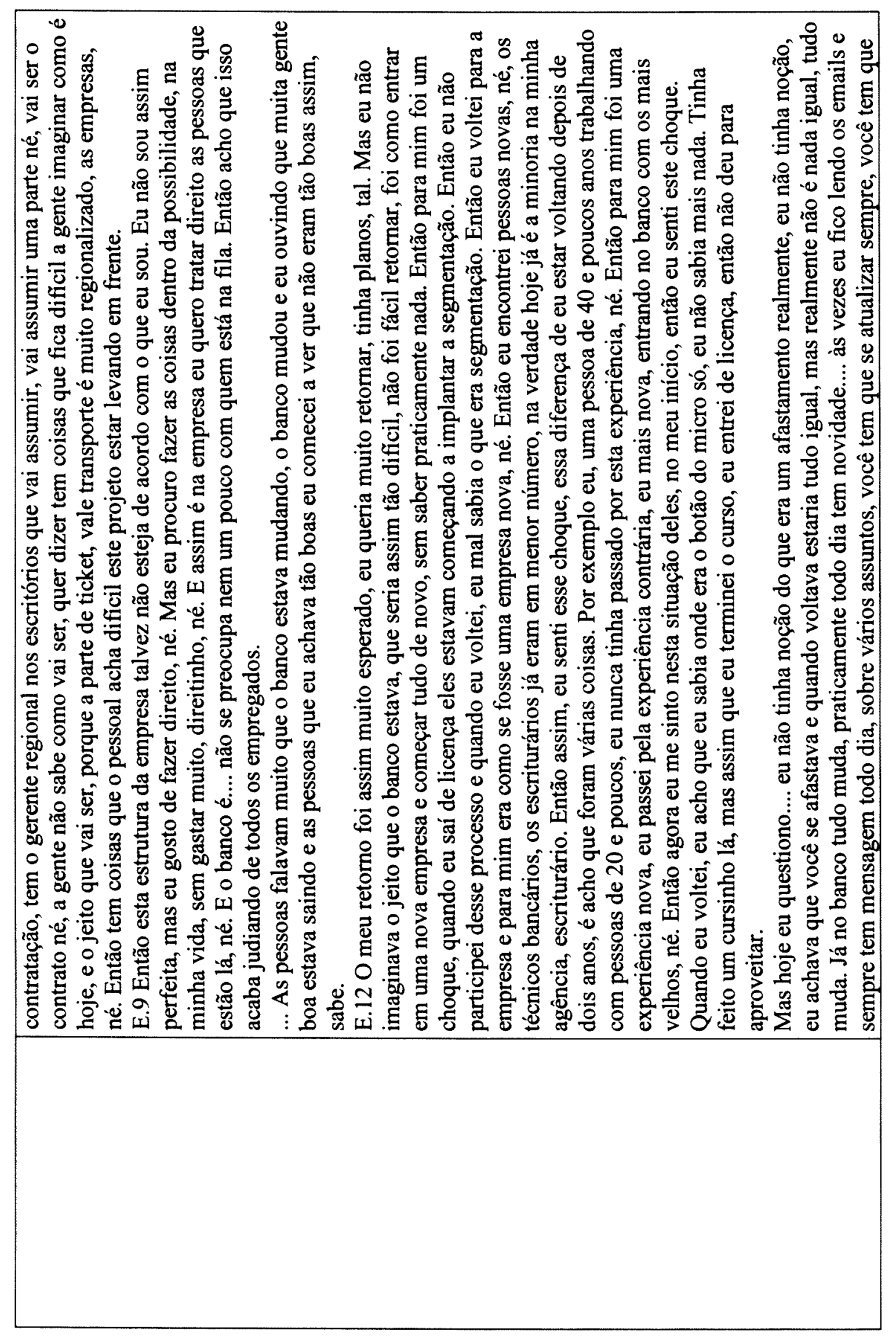




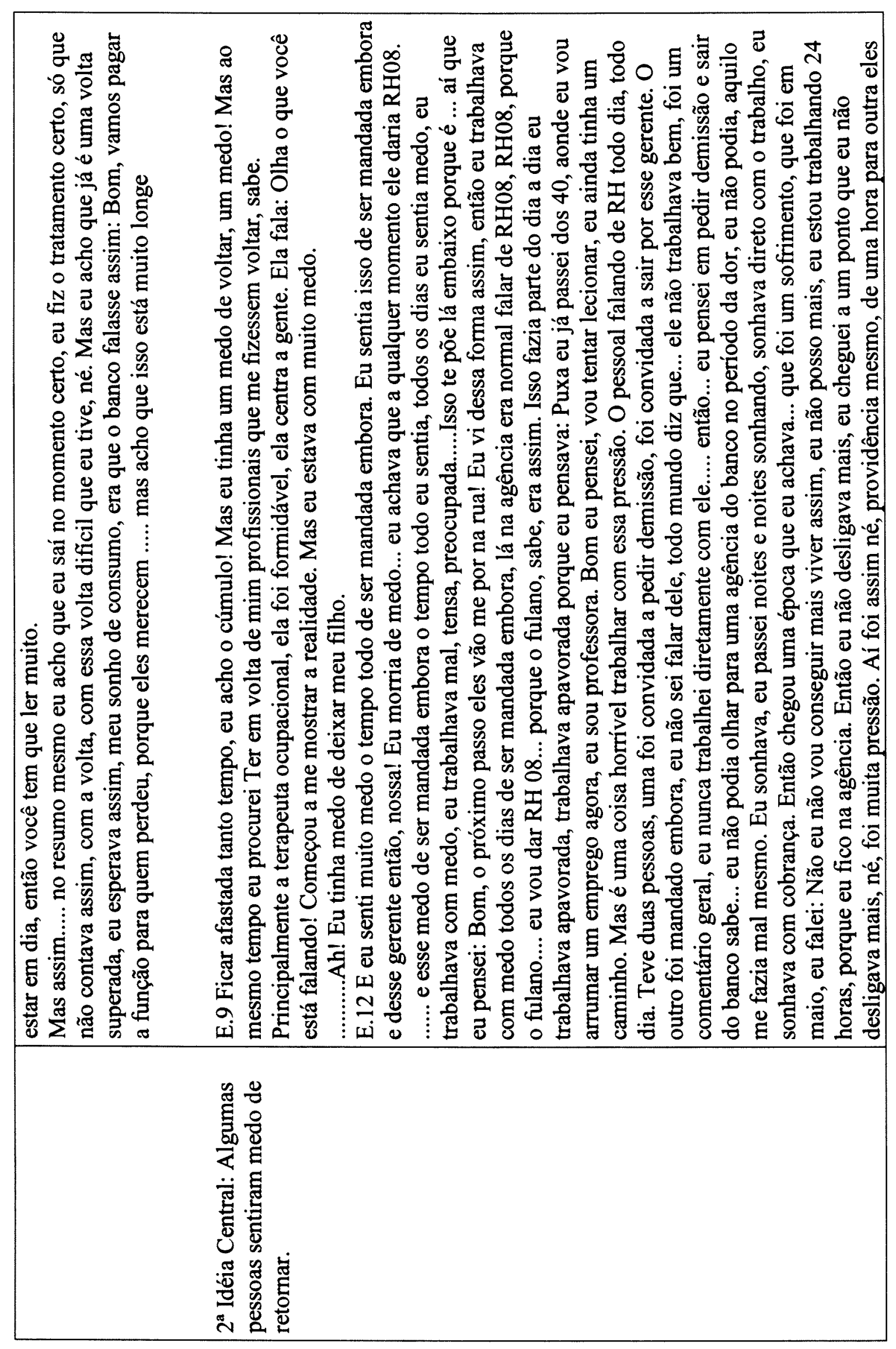




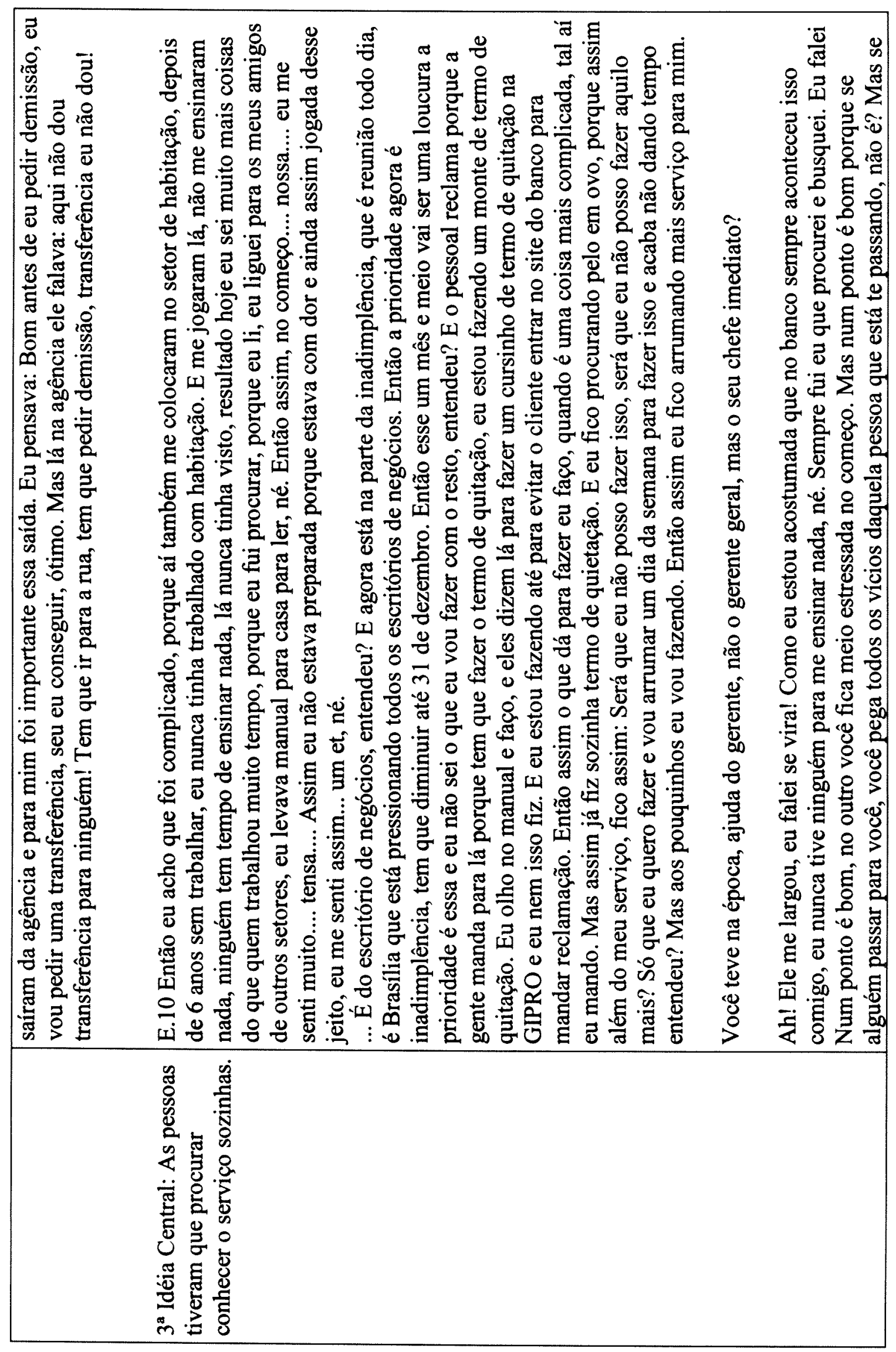



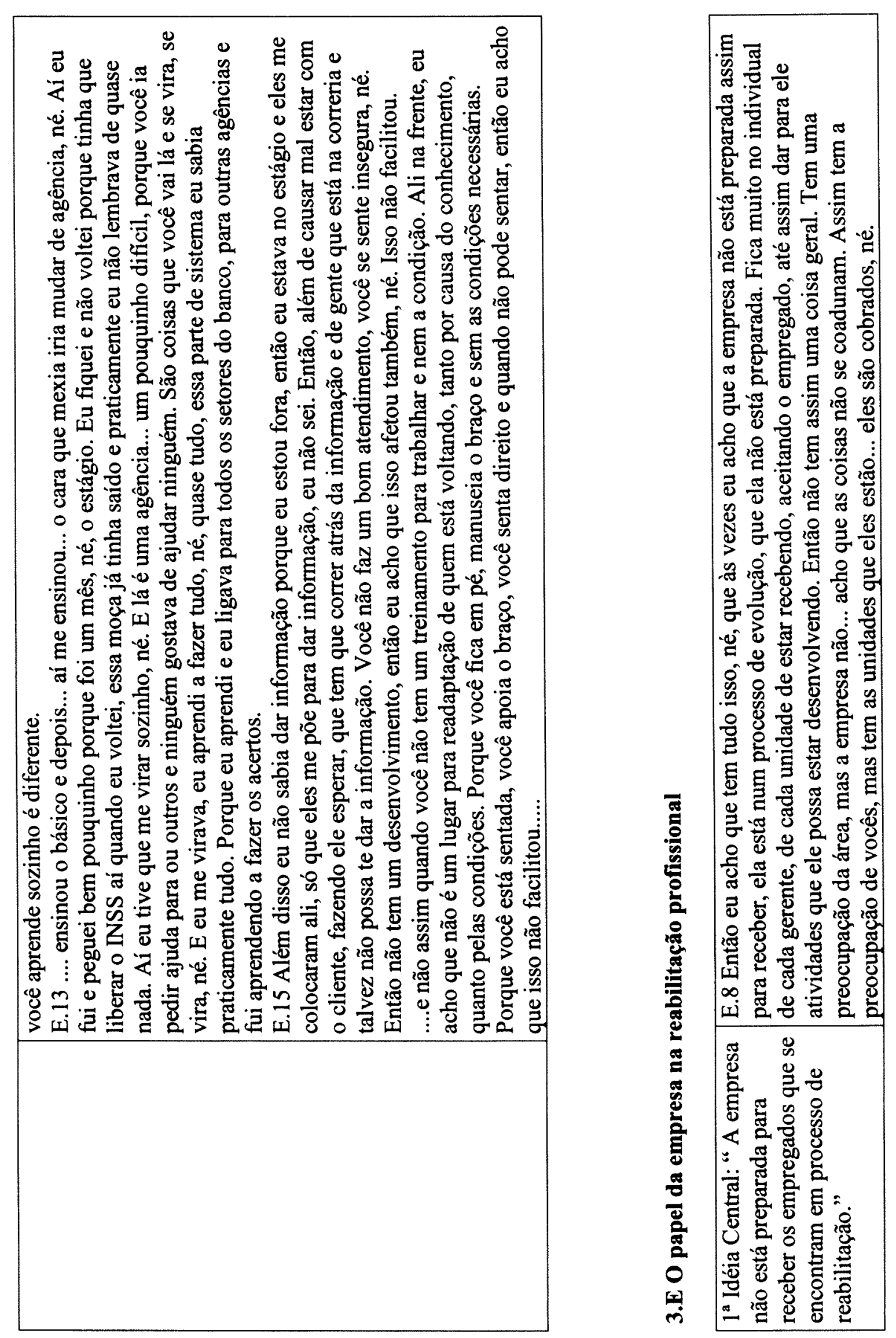


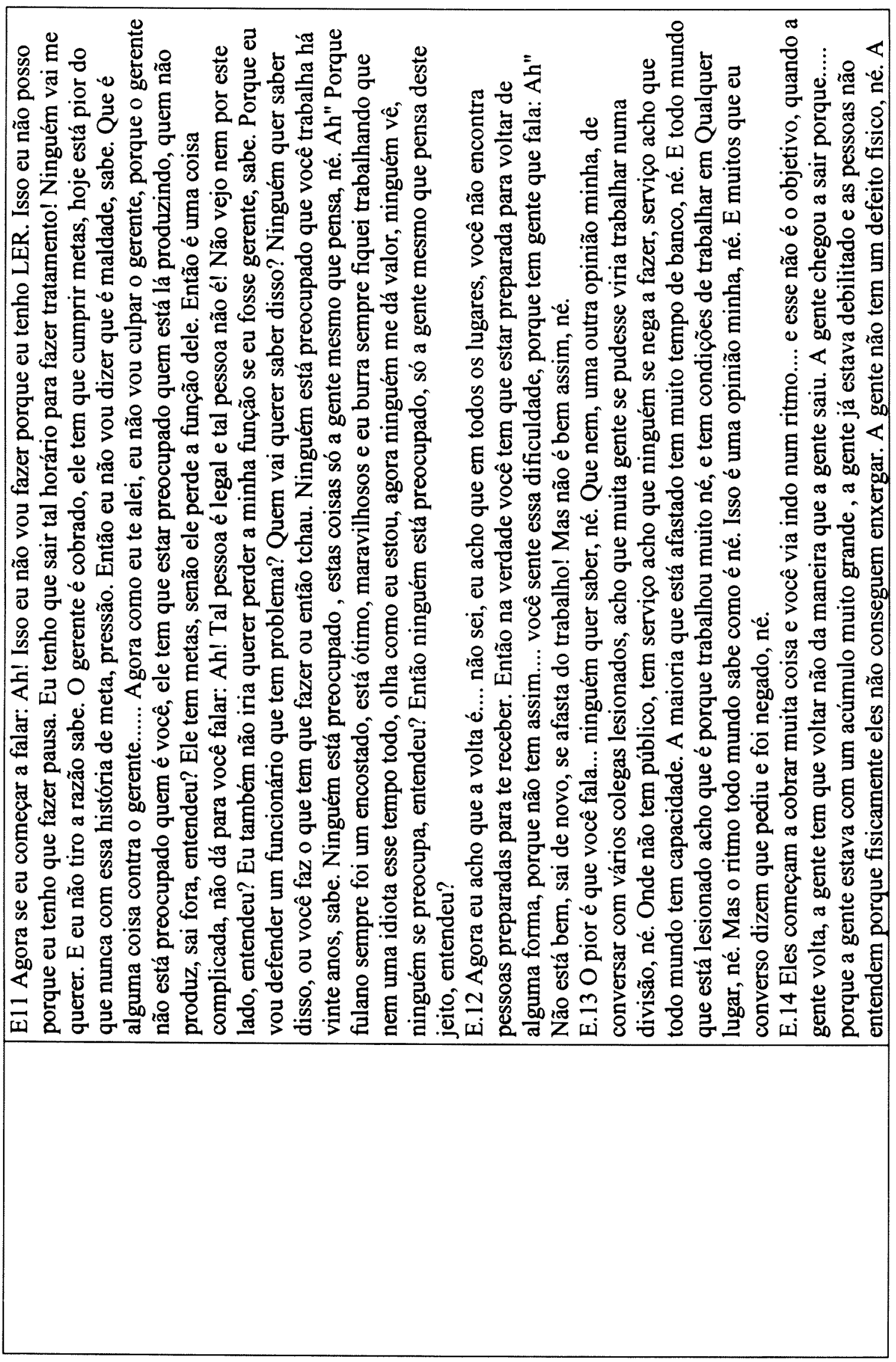



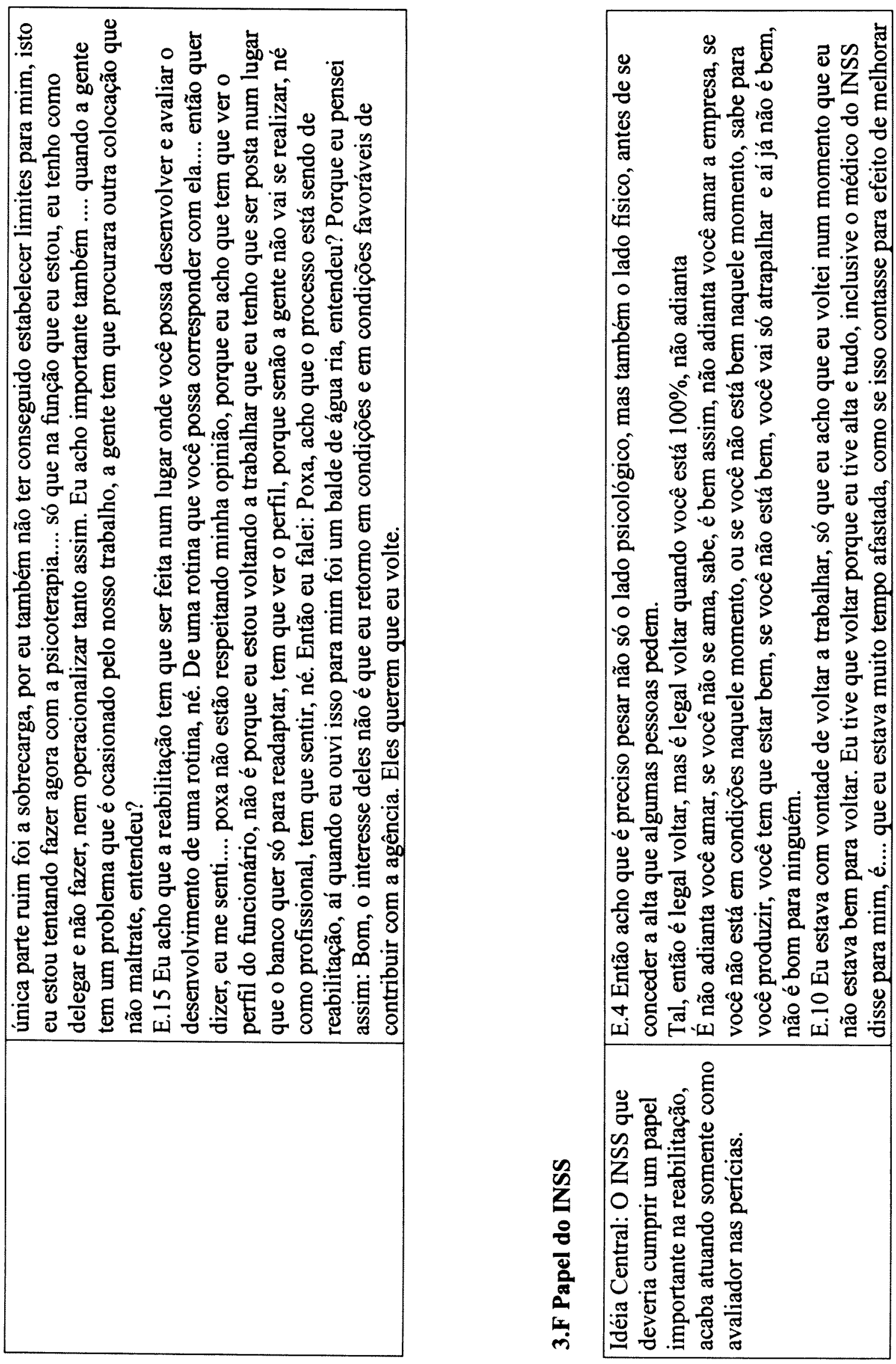


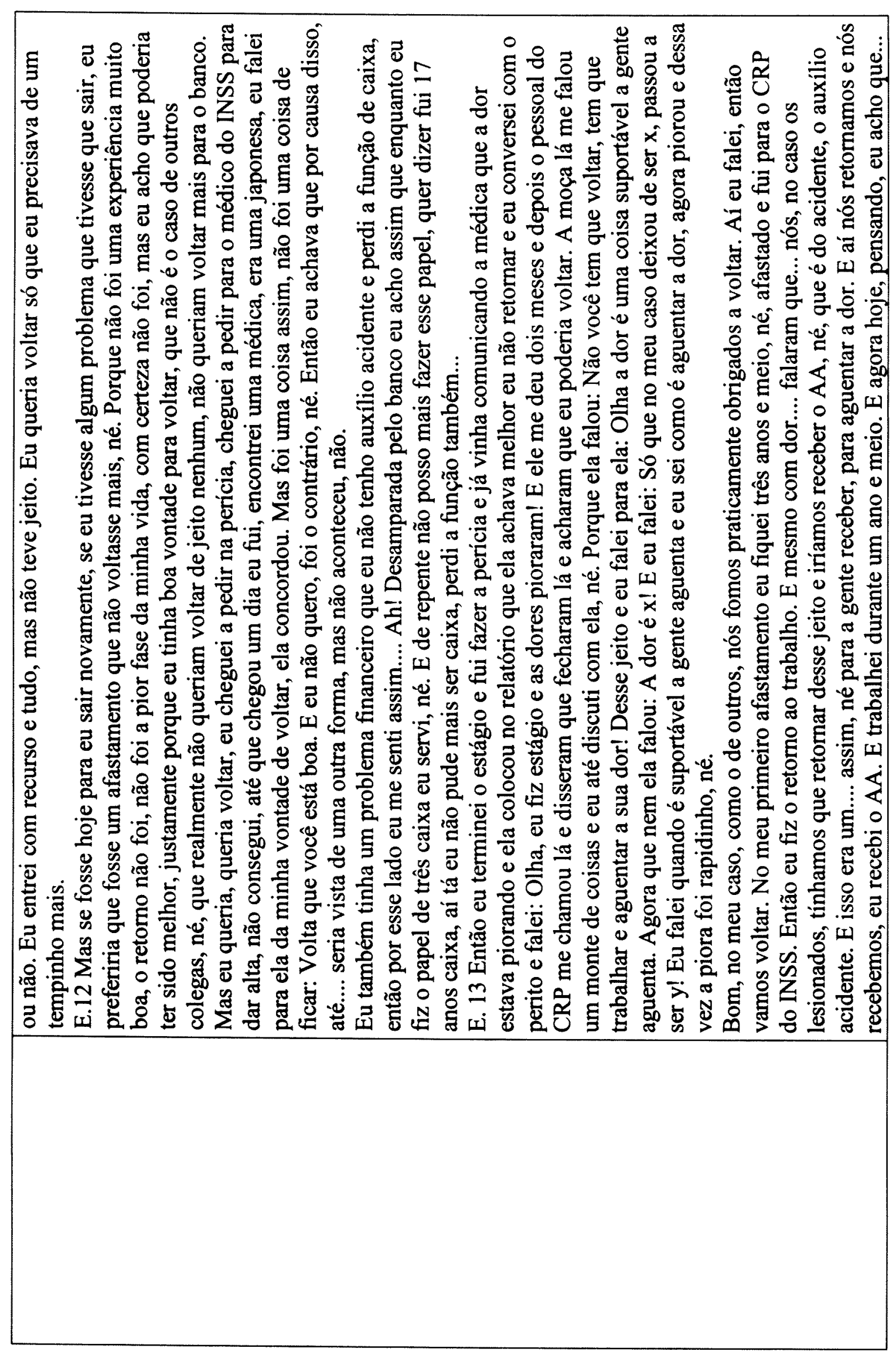



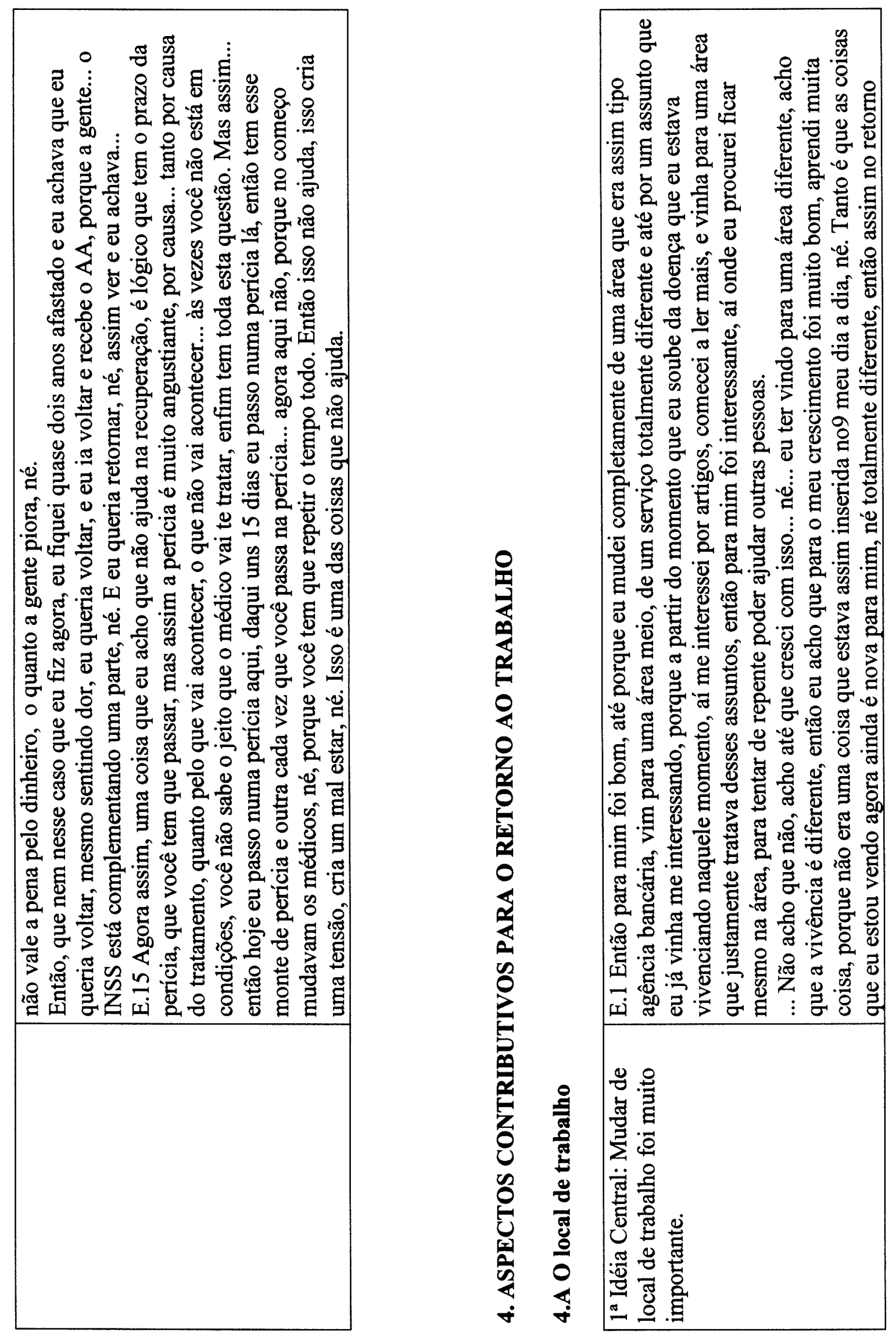


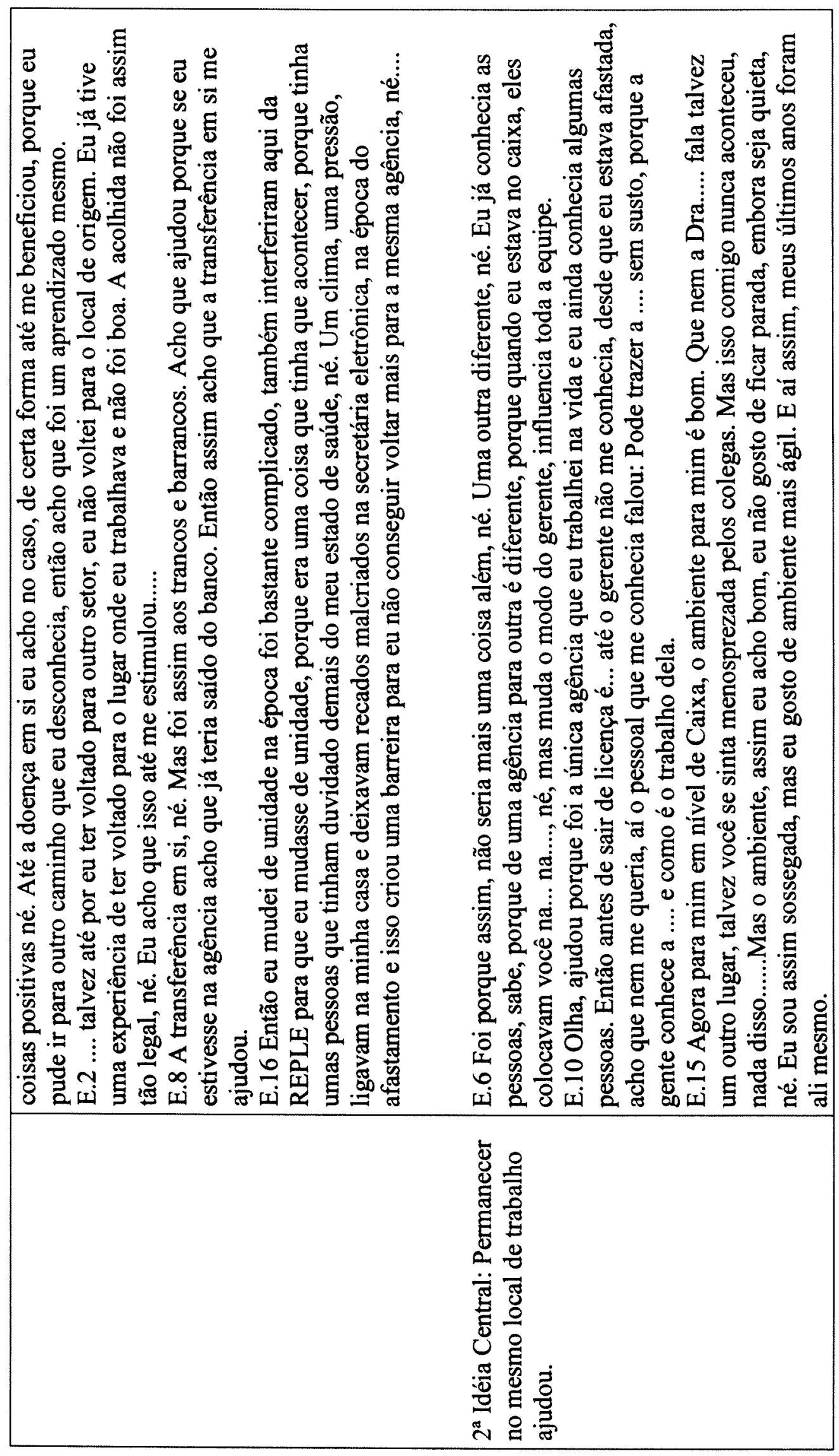




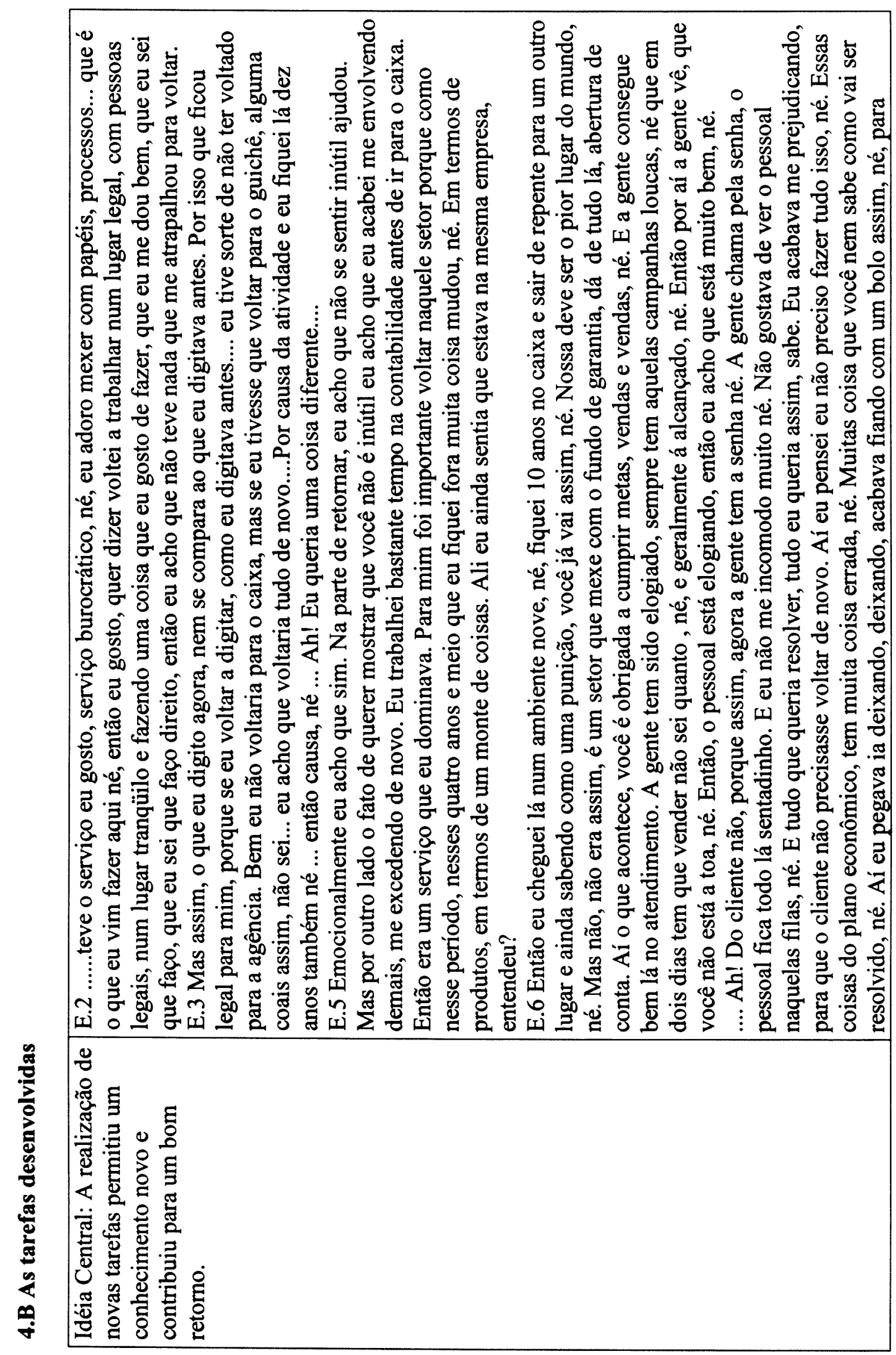




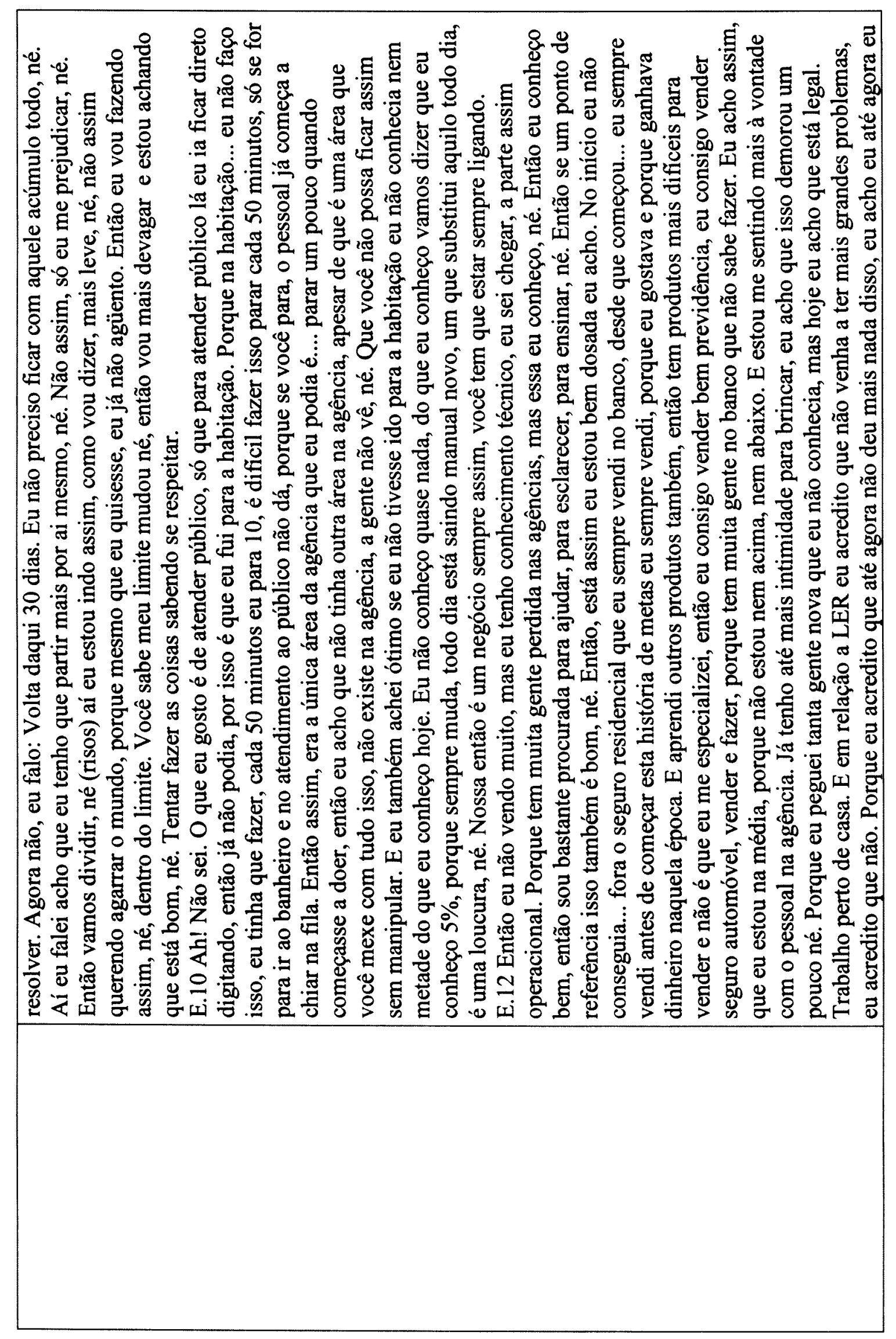



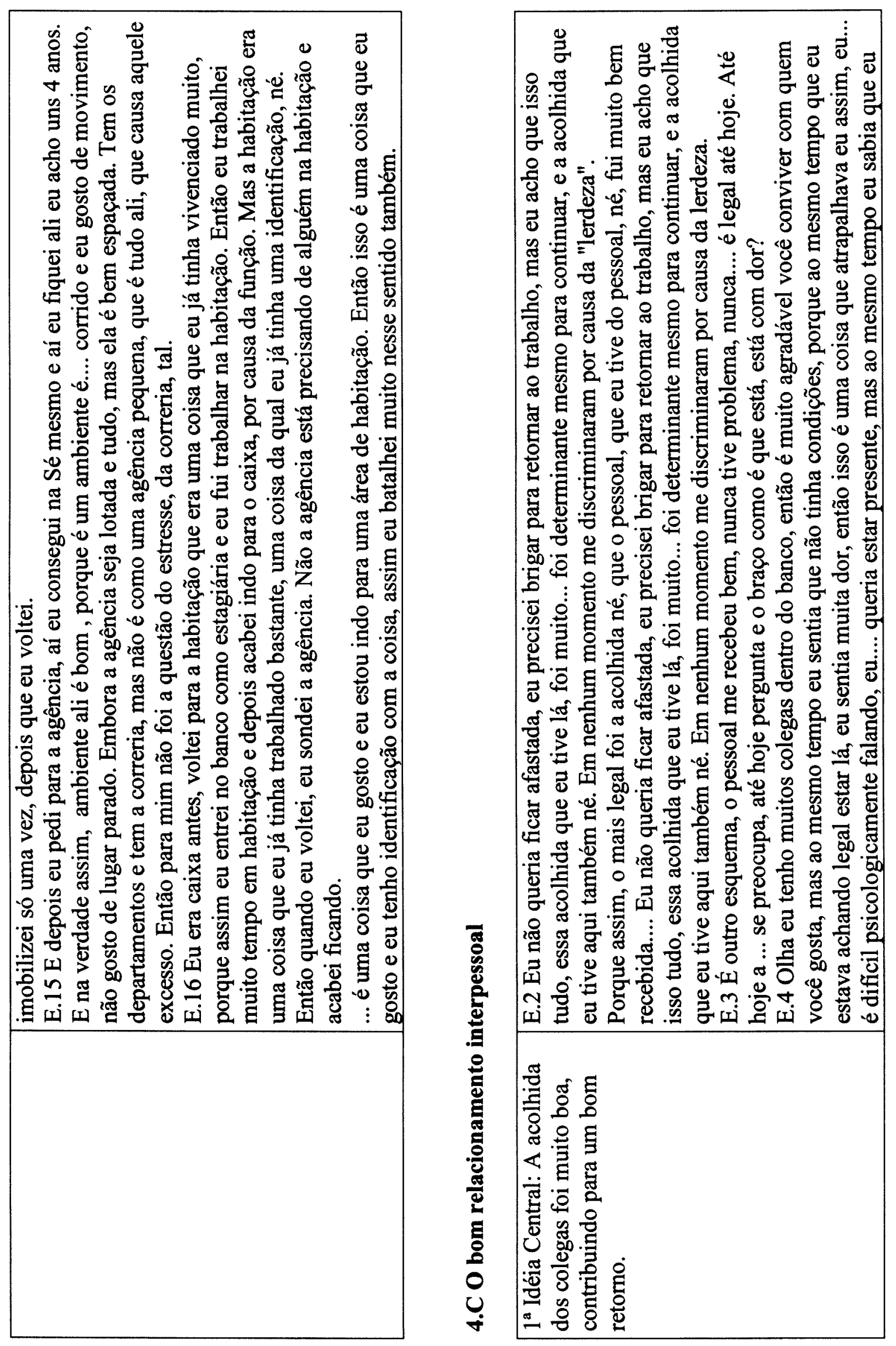


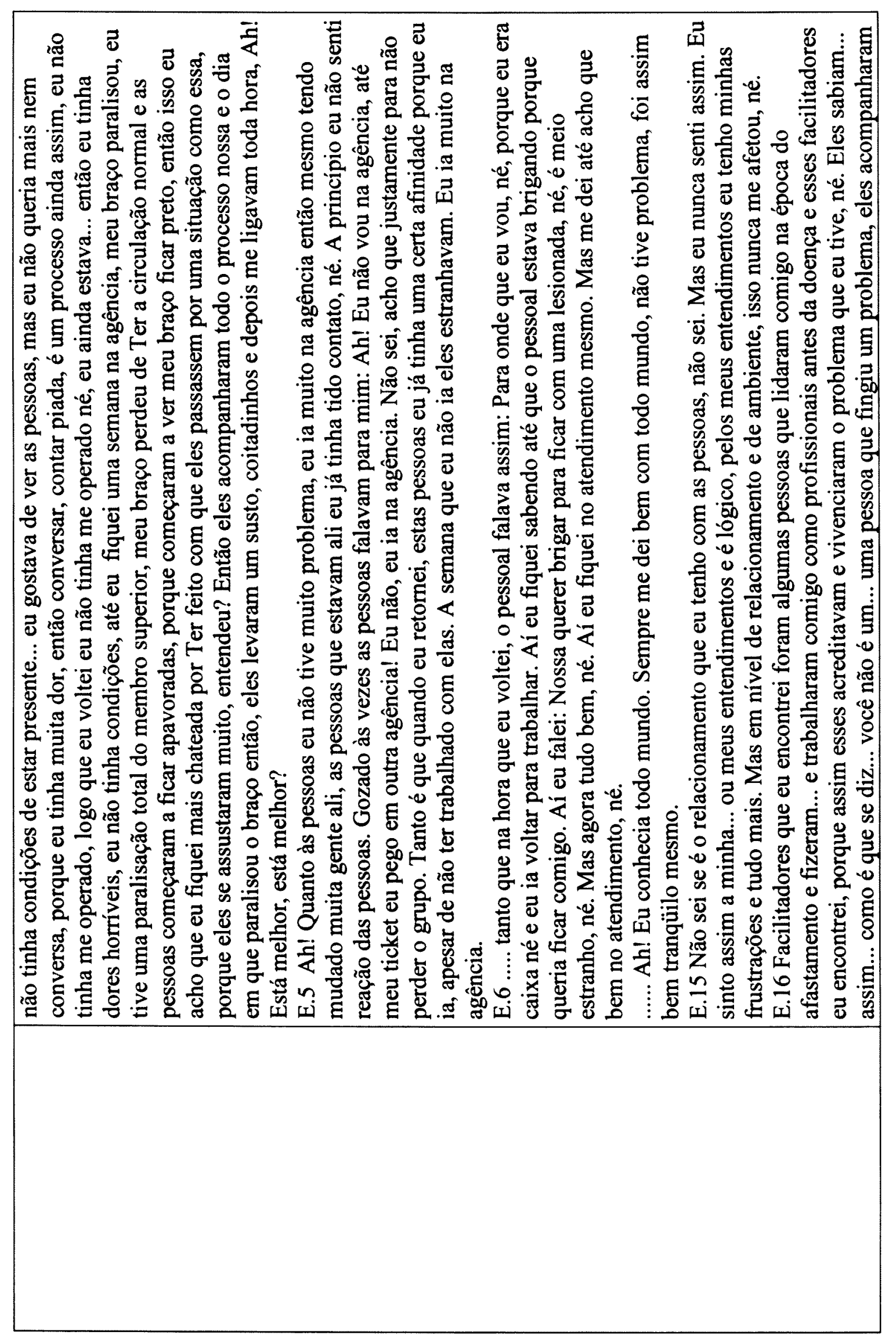



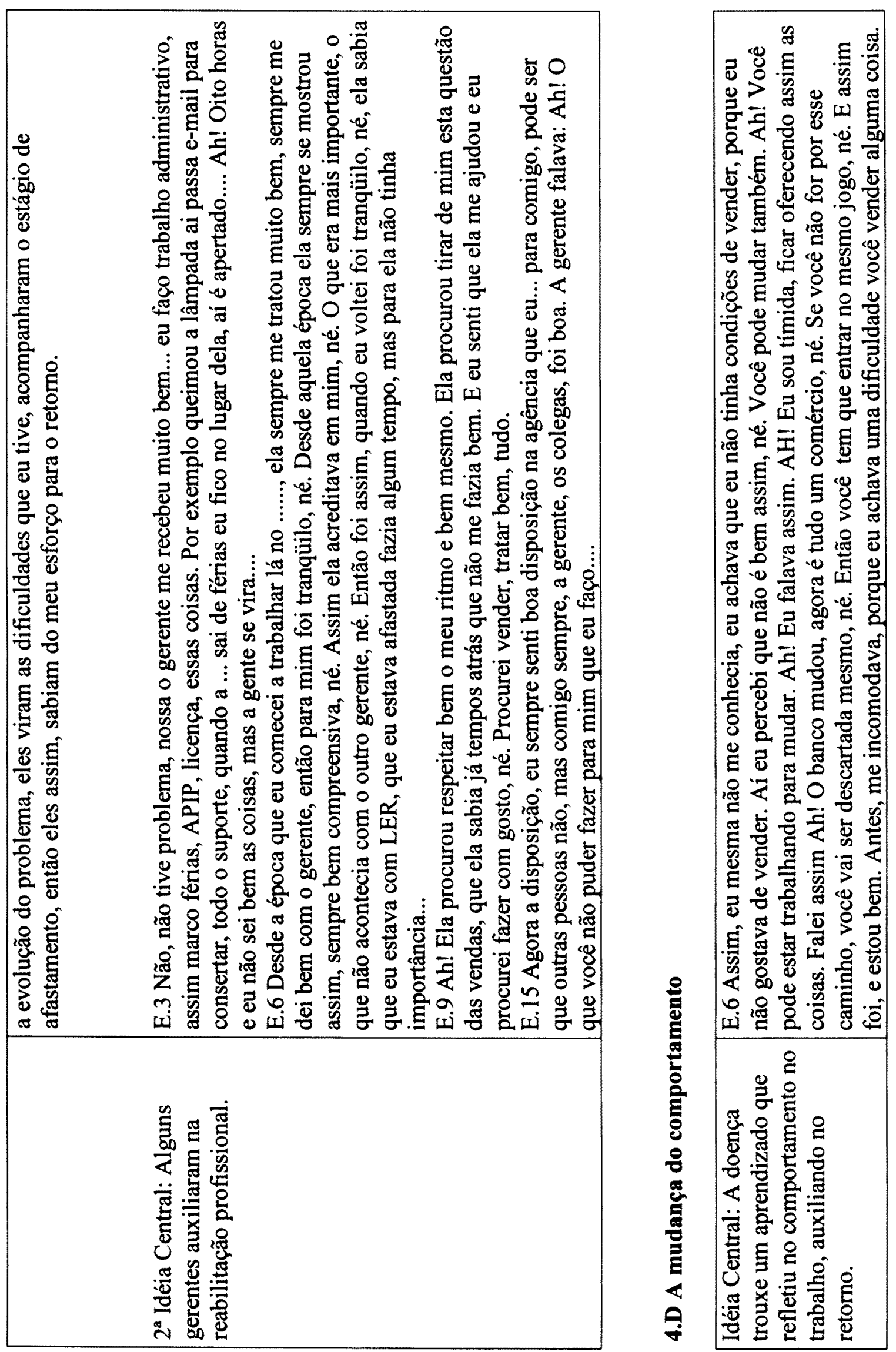


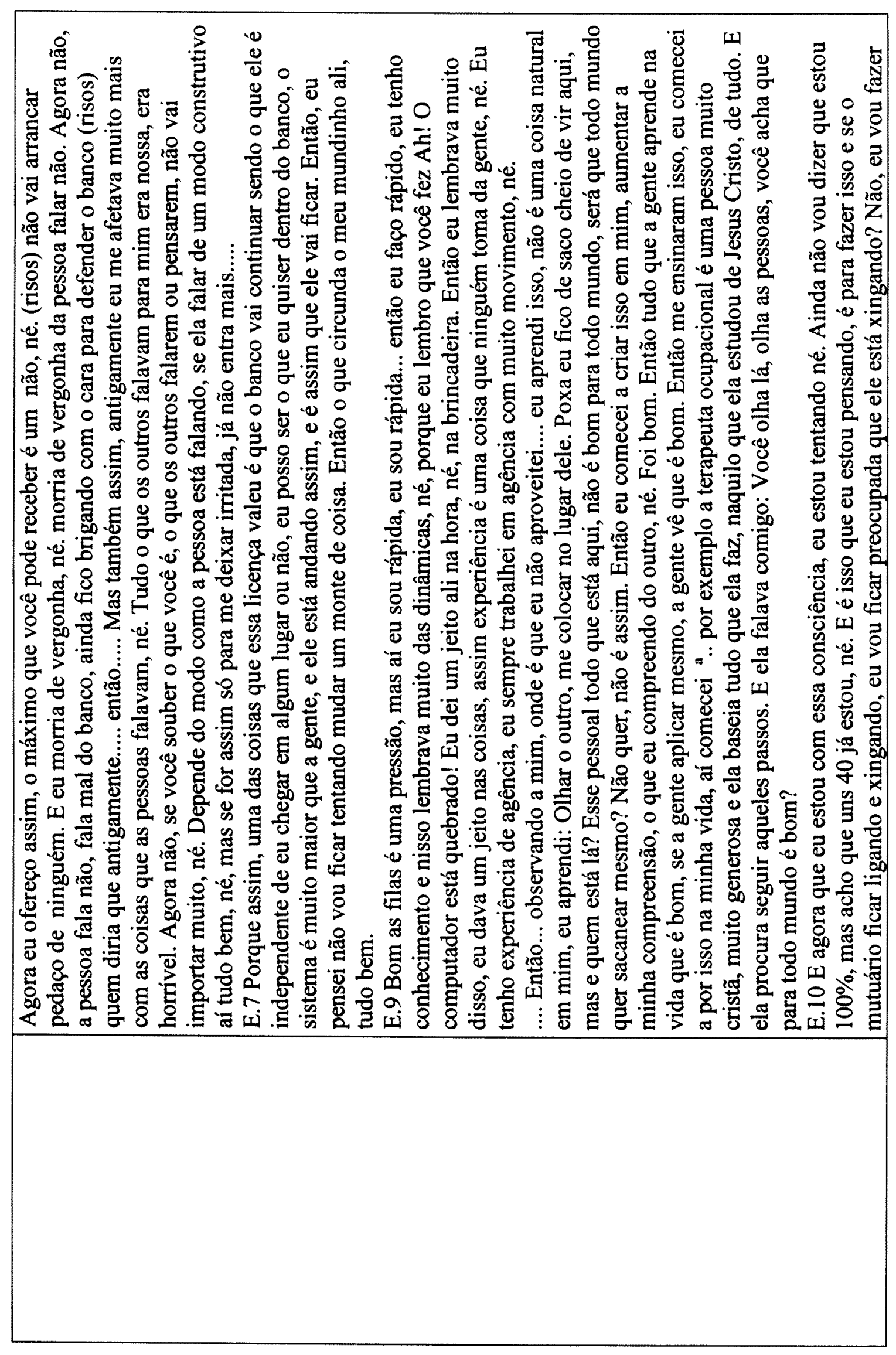



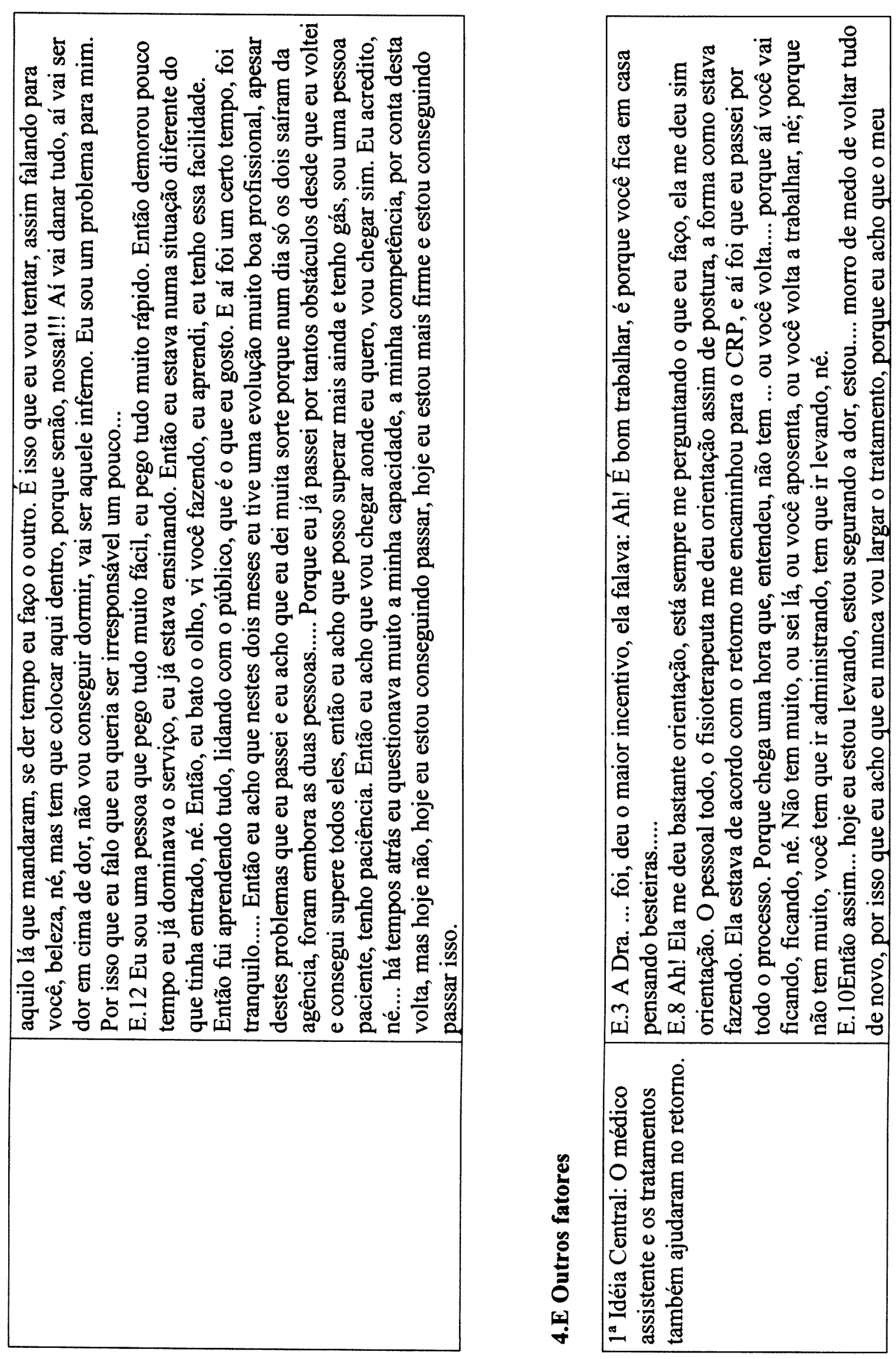


\begin{tabular}{|c|c|c|}
\hline 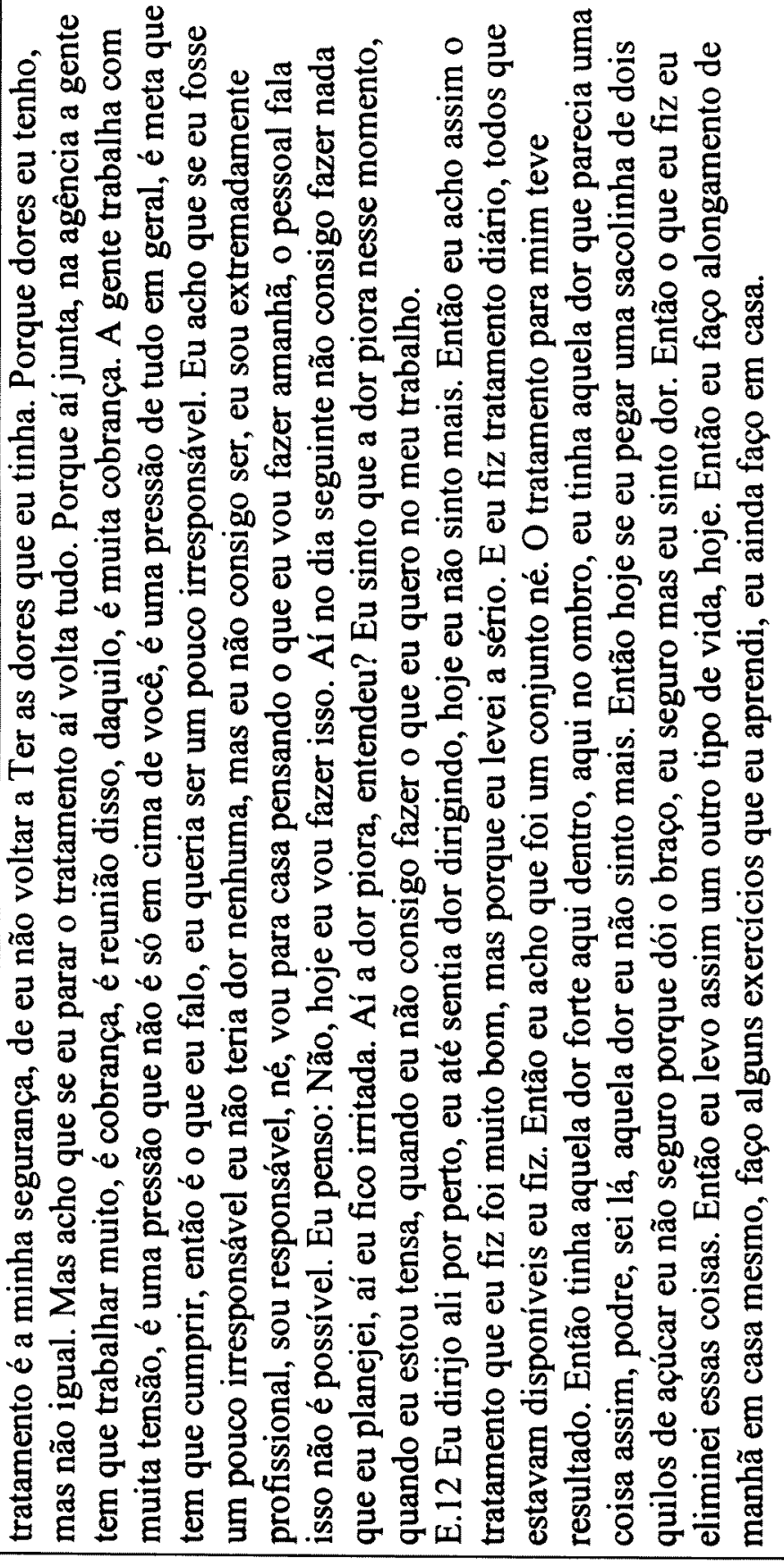 & 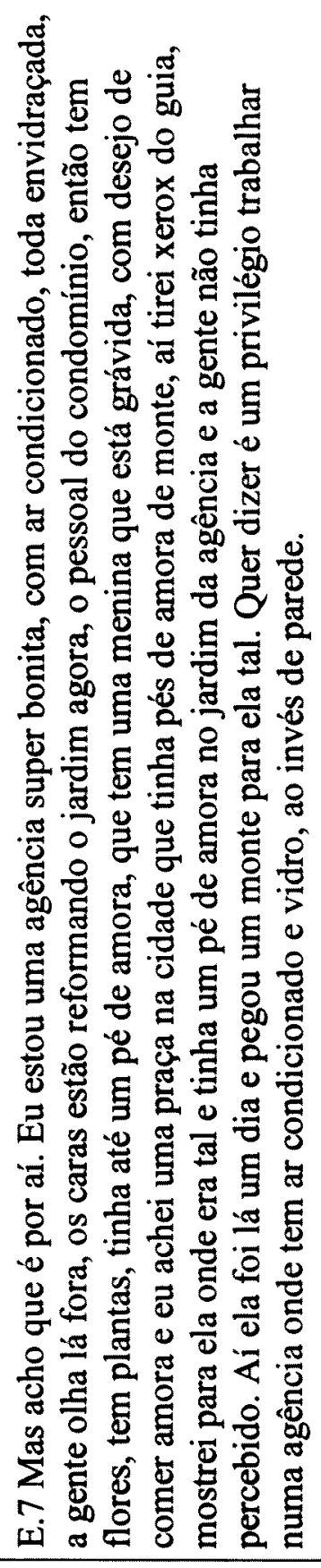 & 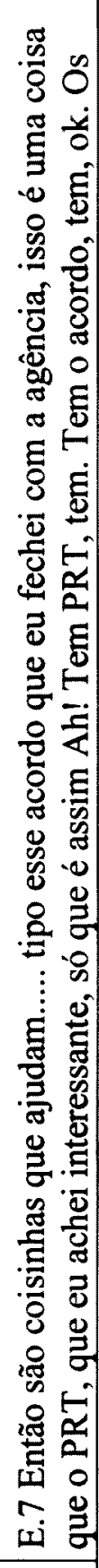 \\
\hline & 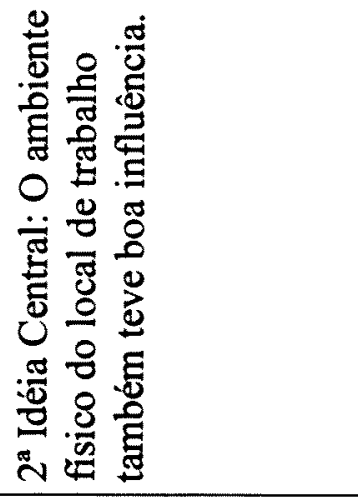 & 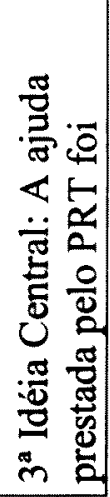 \\
\hline
\end{tabular}




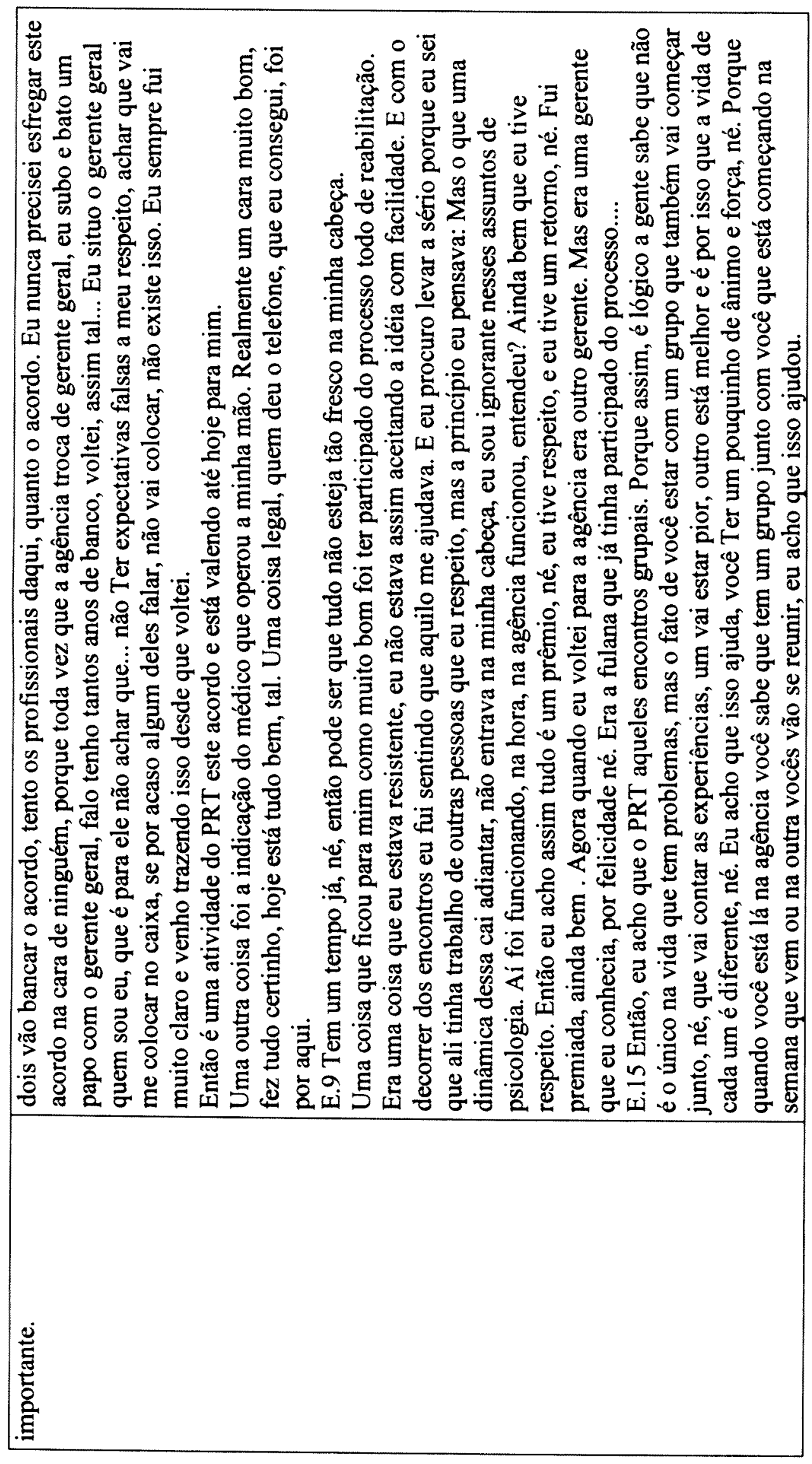




\section{ANEXO IV}

Termo de Consentimento Livre e Esclarecido

Utilizado na presente pesquisa 


\title{
TERMO DE CONSENTIMENTO
}

\author{
BANCARIOS COM LER (Lesão por Esforços Repetitivos) E SUA \\ REABILITAÇÃO PROFISSIONAL: POSSIBILIDADES E LIMITES NO \\ RETORNO AO TRABALHO
}

A pesquisa que vamos realizar, faz parte da defesa de tese de doutorado do Curso de Pós-Graduação da Faculdade de Saúde Pública da Universidade de São Paulo. Para tanto estamos solicitando a sua importante colaboração a fim de responder a algumas perguntas a respeito dos aspectos psicossociais relacionados à reabilitação profissional. Esta pesquisa é muito importante para que as pessoas, especialistas ou não do assunto, olhem de forma mais humana, mais critica sobre este tema.

A história que o (a) Sr. (a) vai nos contar sobre a reabilitação profissional em portadores de LER vai nos ajudar a compreender melhor o problema e permitir algumas propostas de ações visando diminuí-lo ou amenizá-lo.

As estatísticas em geral, como são apresentadas, são frias, referindo-se às pessoas como números, e o que a gente quer é dar vida a esses números, a partir de seu relato.

Solicitamos que o (a) Sr. (a) participe da entrevista que vai ocupar pouco do seu tempo, comprometendo-nos a não divulgar seu nome, nem o que vai nos contar.

Prometemos, também, que logo que terminemos o nosso trabalho, a gente vai retornar para o (a) Sr. (a) as coisas que escrevemos. Asseguramos, inclusive, que a sua participação é livre e voluntária, sendo que, em qualquer momento da entrevista, o (a) Sr. (a) poderá desistir e que esta participação não implica em quaisquer riscos e desconfortos.

Com o compromisso de acompanhar todo o processo de entrevista, colocamo-nos à disposição para esclarecimentos, seja do modo como a gente vai trabalhar, seja do conteúdo e dos objetivos da pesquisa. Esta pesquisa não implica em despesas por parte do entrevistado.

Desde jả agradecemos a sua valiosa colaboração

São Paulo, 2002

Nome do pesquisador

Assinatura do entrevistado

RG e endereço 